\title{
Rapid Bioassessment Methods for Assessing Vegetation Toxicity at the Savannah River Site - Germination Tests and Root Elongation Trials
}

by

W. L. Specht

Westinghouse Savannah River Company

Savannah River Site

Aiken, South Carolina 29808

\section{MASTER}

DOE Contract No. DE-AC09-89SR18035

This paper was prepared in connection with work done under the above contract number with the U.S.

Department of Energy. By acceptance of this paper, the publisher and/or recipient acknowledges the U.S. Government's right to retain a nonexclusive, royalty-free license in and to any copyright covering this paper, along with the right to reproduce and to authorize others to reproduce all or part of the copyrighted paper. 


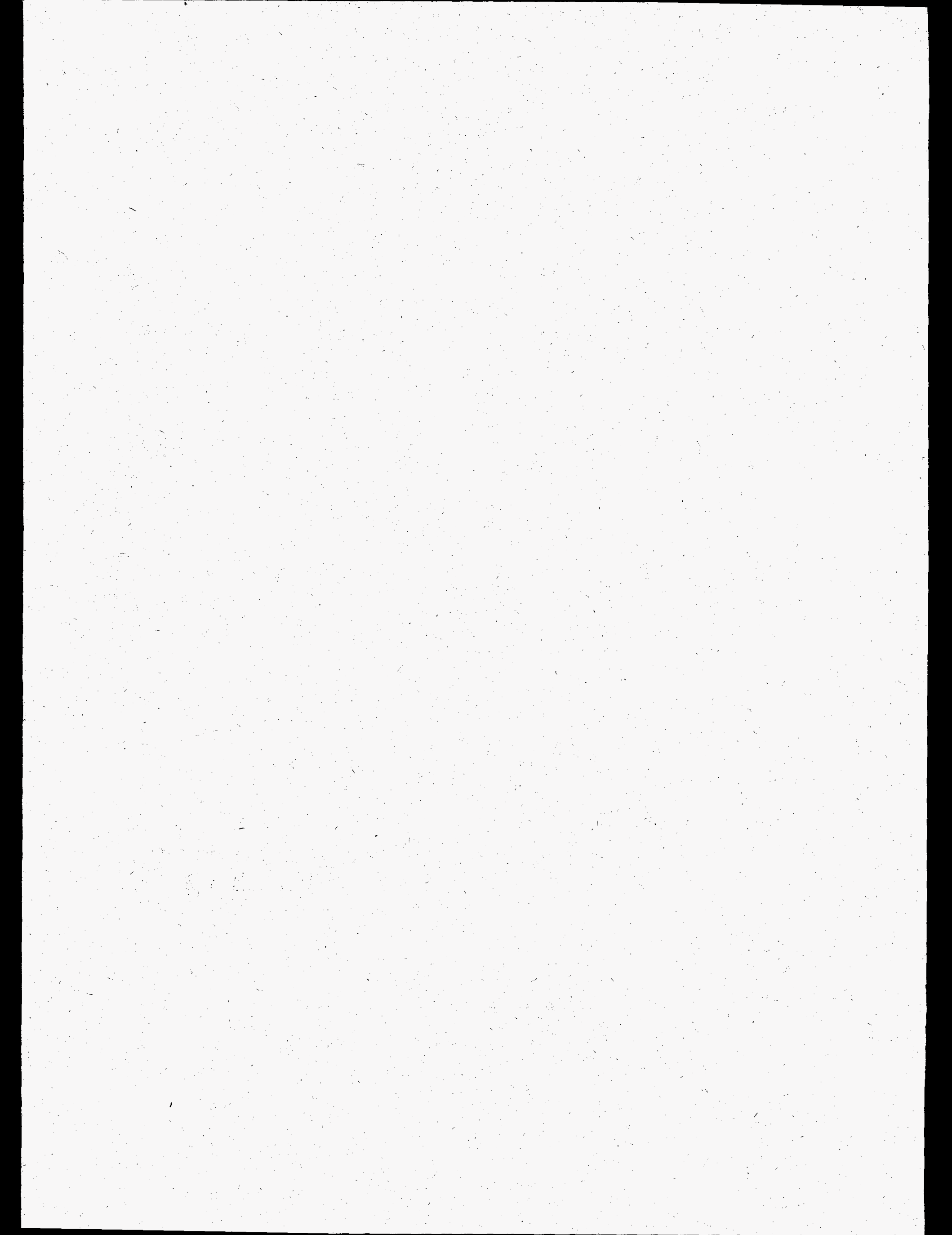




\section{DISCLAIMER}

This report was prepared as an account of work sponsored by an agency of the United States Government. Neither the United States Government nor any agency thereof, nor any of their employees, makes any warranty, express or implied, or assumes any legal liability or responsibility for the accuracy, completeness, or usefulness of any information, apparatus, product, or process disclosed, or represents that its use would not infringe privately owned rights. Reference herein to any specific commercial product, process, or service by trade name, trademark, manufacturer, or otherwise does not necessarily constitute or imply its endorsement, recommendation, or favoring by the United States Government or any agency thereof. The views and opinions of authors expressed herein do not necessarily state or reflect those of the United States Government or any agency thereof.

This report has been reproduced directly from the best available copy.

Available to DOE and DOE contractors from the Office of Scientific and Technical Information, P.O. Box 62, Oak Ridge, TN 37831; prices available from (615) 576-8401.

Available to the public from the National Technical Information Service, U.S. Department of Commerce, 5285 Port Royal Road, Springfield, VA 22161. 


\section{DISCLAMMER}

Portions of this document may be illegible in electronic image products. Images are produced from the best available original document. 


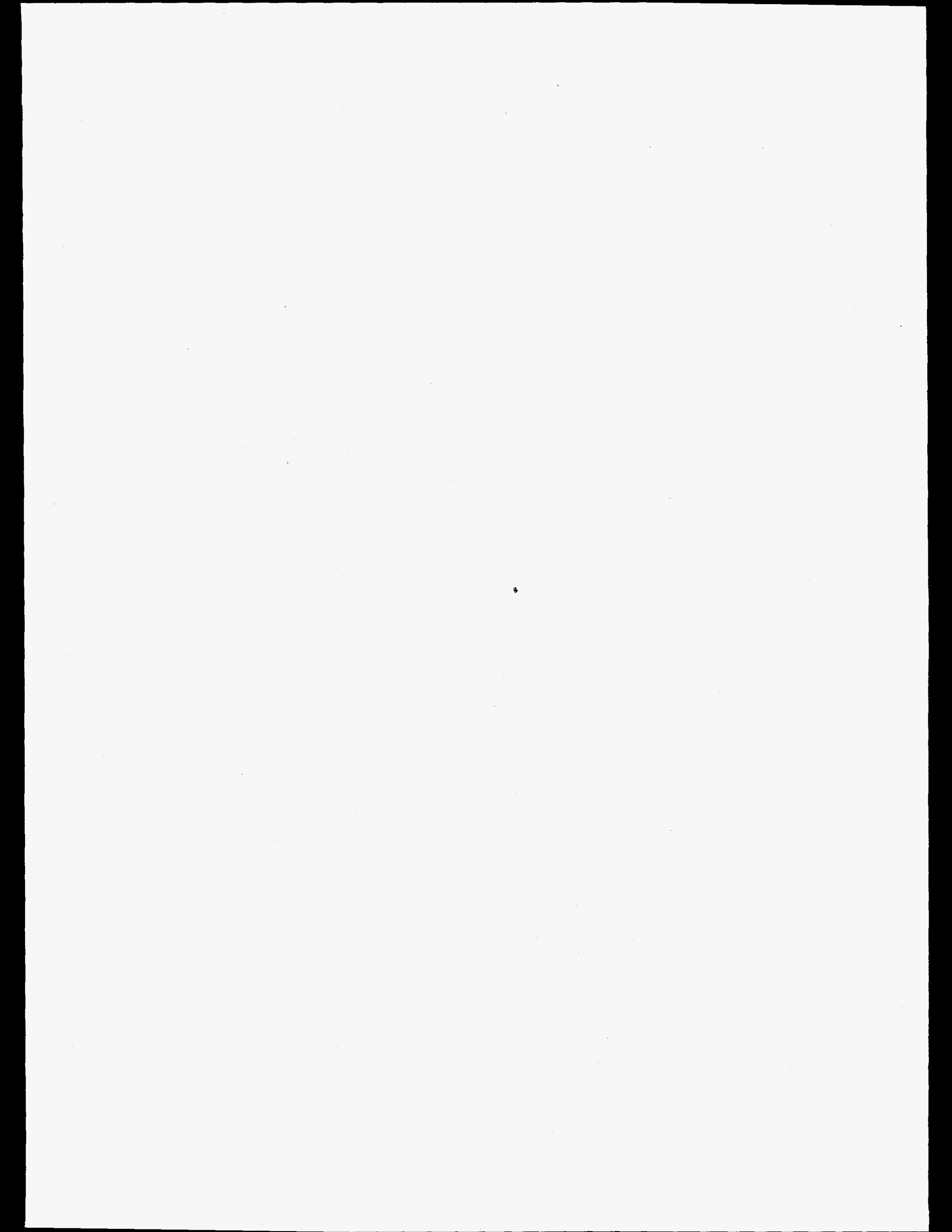




\title{
RAPID BIOASSESSMENT METHODS FOR ASSESSING VEGETATION TOXICITY AT THE SAVANNAH RIVER SITE- GERMINATION TESTS AND ROOT ELONGATION TRIALS
}

\author{
by \\ STEPHEN J. KLAINE, DONAL D. HOOK, \\ SUSAN STOKES AND HEATHER SUTTON, \\ THE INSTITUTE OF WILDLIFE AND ENVIRONMENTAL TOXICOLOGY, \\ DEPARTMENT OF ENVIRONMENTAL TOXICOLOGY \\ AND THE DEPARTMENT OF FOREST RESOURCES \\ CLEMSON UNIVERSITY
}

Approved by:

DBmand Shedurs
D.B. Moore-Shedrow, Section Manager
Environmental Sciences Section
Savannah River Technology Center

Publication Date: January 1996

WESTINGHOUSE SAVANNAH RIVER COMPANY SAVANNAH RIVER SITE AIKEN, SC 29808

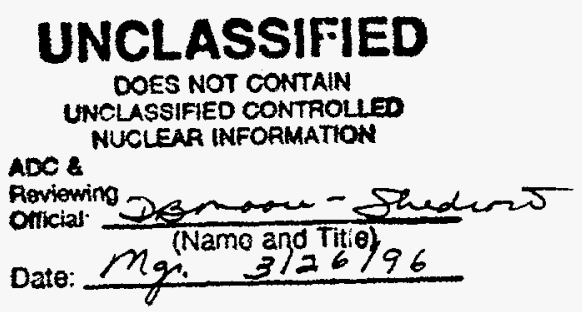

THIS DOCUMENT WAS PREPARED IN CONNECTION WITH WORK UNDER U.S. DEPARTMENT OF ENERGY CONTRACT DE-AC09-88SR18035. By acceptance of this paper, the publisher and/or recipient acknowledges the U.S. Government's right to retain a nonexclusive, royalty-free license in and to any copyright covering this paper, along with the right to reproduce and to authorize others to reproduce all or any part of the copyrighted paper. 
FINAL REPORT

\section{GERMINATION TESTS AND PRELIMINARY ROOT ELONGATION TRIALS}

By

Stephen J. Klaine, Professor, Department of Environmental Toxicology and the Institute of Wildlife and Environmental Toxicology, Clemson University;

Donal D. Hook, Professor, Department of Forest Resources, Clemson University;

Susan Stokes, Department of Forest Resources, Clemson University; and

Heather Sutton, The Institute of Wildlife and Environmental Toxicology, Clemson University

To

Savannah River Technology Center

Westinghouse Savannah River Company

Aiken, SC 29808

August 31, 1995 


\section{TABLE OF CONTENTS}

Topic

Page

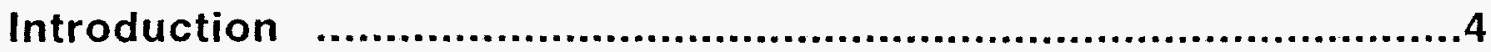

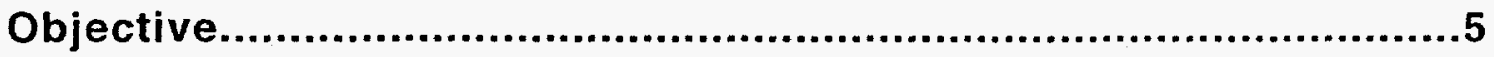

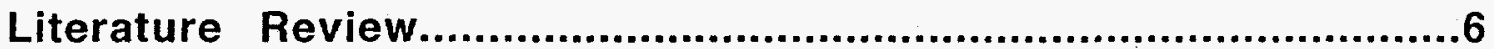

Contaminants Used in This Study..........................................10

Methods....................................................................................11

Seed Collection and Identification......................................................11

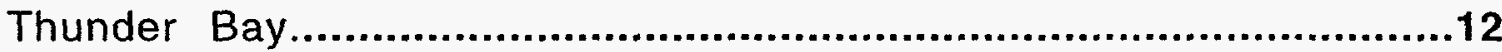

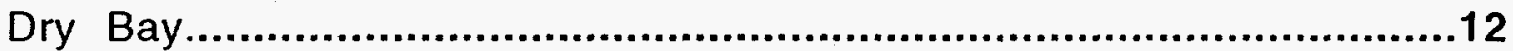

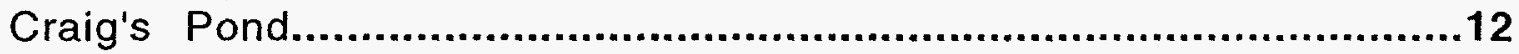

Ellenton Bay..............................................................................12

Compound 3 Bay.........................................................................13

Initial Stock Solution and Dilution Preparations...........................................14

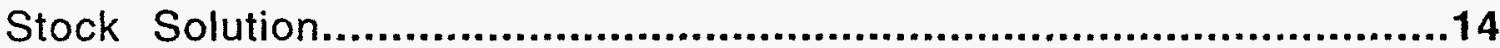

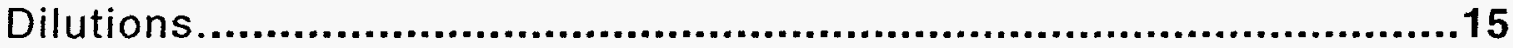

Revised Stock Solution and Dilution Preparations....................................18

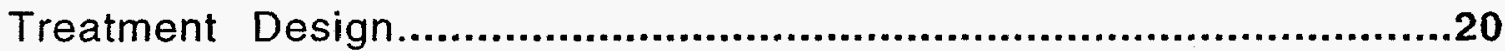

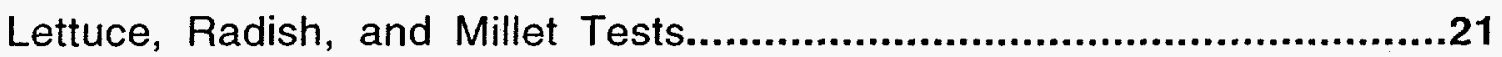

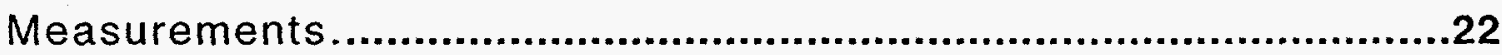

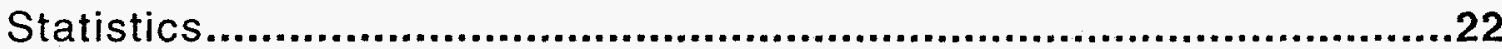

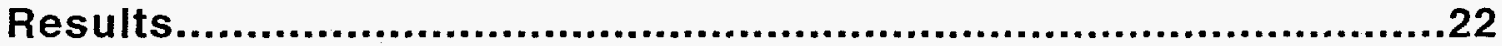

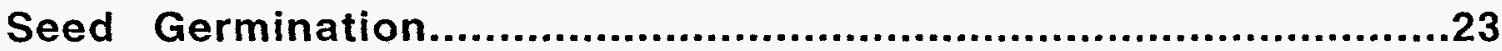

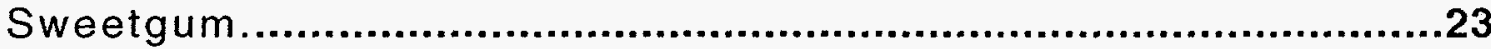

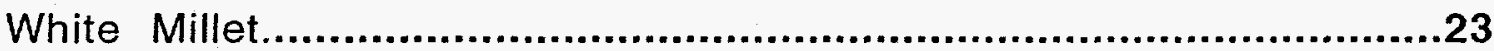

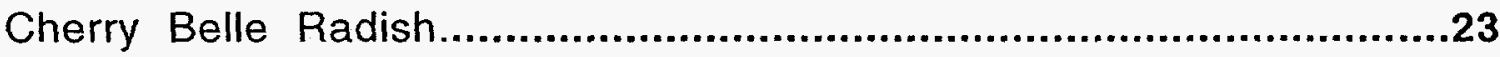

Lizard's Tail.............................................................................23

Buttercrunch Lettuce..................................................................24

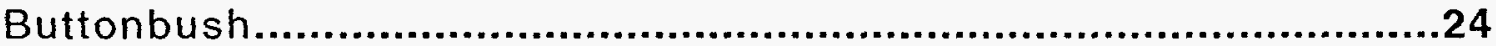

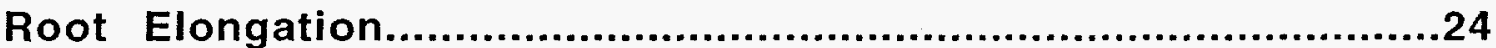

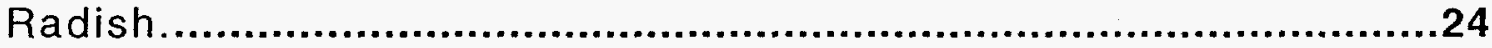

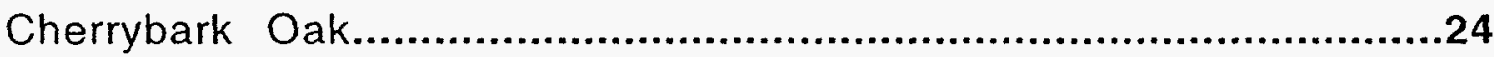

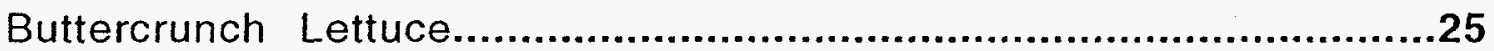

Comparison of Wild Species to Domestic Species........................25

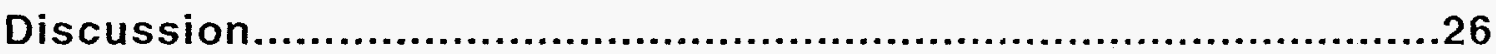




\section{Part 2:}

Definitive Seed Germination and Root Elongation Studies..........27 Literature Cited for Plant Identification .33

General Literature Cited. .33 


\section{INTRODUCTION}

Plants form the basis of all ecosystems including wetlands. Although they are the most abundant life form and are the primary producers for all other organisms, they have received the least attention when it comes to environmental matters (Fletcher, 1991). Higher plants have rarely been used in ecotoxicity testing (Wang and Williams, 1988), and may not respond in the same manner as algae, which have been used more frequently. The introduction of hazardous waste materials into wetland areas has the potential to alter and damage the ecological processes in these ecosystems. Measuring the impact of these contaminants on higher plants is therefore important and needs further research.

Higher plants are useful for detecting both herbicidal toxicity and heavy metal toxicity (Wang and Williams, 1988). For phytotoxicity tests to be practical they must be simple, inexpensive, yet sensitive to a variety of contaminants. A difference between seed germination and root elongation tests is that seed germination tests measure toxicity associated with soils directly, while root elongation tests consider the indirect effects of water-soluble constituents that may be present in site samples (Linder et al, 1990).

There are seven basic classes of plant phytotoxicity tests available; enzyme assays, process measurements, tissue culture growth, life cycle, seedling growth, seed germination, and root elongation. Of these seven, only the last three are currently required to be used by the EPA, FDA, and the OECD. The plant species recommended for use in these tests include no native species (Fletcher, 1991). In areas such as the southeastern United States, where agroecosystems exist as a patchwork of crops and native woodlots, alongside industry, there is a real question as to whether the surrogate species recommended by these agencies adequately protect native plant communities (Fletcher et al, 1990). Virtually no toxicology data exists for most native plant families (Fletcher et al, 1985), and it is an aim of the current project to begin to address this issue for native wetland species. 
The main effects of metal ions on living systems result from the role of metals in enzyme expression and regulation (Wang and Elseth, 1990). The uptake by plants of phytotoxic amounts of metal can result in the inhibition of several enzymes and an increase in the activity of others. There are two main mechanisms of enzyme inhibition, 1) the metal binds to sulfhydryl groups that are involved in the catalytic action or structural integrity of enzymes, and 2) a deficiency of an essential metal in metalloproteins or metal-protein complexes occurs as a result of substitution of that metal by the toxic metal(s) (Van Assche and Clijsters, 1990).

Jones and Sharitz (1990) found that cohorts of seedlings in bottomland hardwood forests that emerged earlier in the growing season had a greater survival than those that emerged later, both at the end of the first growing season and by the fall of the next year. Seedlings that emerged before rather than after simulated leaf-out could grow a magnitude larger, and thus it is possible that early germination can affect the fitness of individual genotypes (Jones and Sharitz, 1989). Thus, a delay in germination as a result of exposure to a contaminant could have effects later on in the life of that seedling. Probably the most vulnerable time in a plant's life cycle is the establishment of the newly germinated seedling (Egley, 1986).

\section{OBJECTIVE}

The objective of the current study was to measure the seed germination response of a number of wetland species native to the Savannah River Site, S.C., to five representative contaminants: cadmium, nickel, anthracene, atrazine, and tetrachloroethylene (PCE). Root elongation work was begun and will be completed in Part 2 of this project. Native species used were Cephalanthus occidentalis (button bush), Saururus cernuus (lizard's tail), Liquidambar styraciflua (sweetgum), and Quercus falcata (cherrybark oak). Three agricultural species, Lactuca sativa (lettuce), Raphanus sativus (radish), and Panicum miliaceum (white millet) were also tested as reference species. 


\section{LITERATURE REVIEW}

The two endpoints measured in this study, seed germination, and root elongation, have been used in other studies. The vast majority of these studies have dealt with commercially important agricultural species, or with weed species with the purpose for the study being better control through herbicides. However, there are a few studies where the objective has been biomonitoring of contaminants. Wang and Williams (1988) used cabbage (Brassica oleracea), cucumber (Cucumis sativus), millet (Panicum miliaceum), Japanese millet (Echinochloa crusgalli), rice (Oryza sativa), and wheat (Triticum aestivum) seeds to screen and biomonitor complex effluent samples. Of these species, millet, Japanese millet, and rice inhabit wetland and riverine ecosystems. Seeds were incubated in the dark for 120 hrs which was sufficient to allow these species enough time to germinate. It was found that cabbage, cucumber, and millet were able to detect phytotoxicity in all the samples, and were thus concluded to be promising test species.

Millet root elongation was used to test the toxicity of phenol and seven chlorophenols (Wang, 1985b). Toxicity generally increased with increasing chlorination of the compound. Root elongation was found to be more sensitive than the biomass method used on this species in an earlier study (see below in "other tests"). However the results were more variable (SD=30\% or more) due to the fact that root elongation is a measure of individual plants. Interestingly, when the concentration of the phenolic compounds was low, root growth was stimulated. Root growth stimuation in response to low levels of toxicants has been found in other studies. In tests with collards (Brassica oleracea) concentrations of vanadium less than $1 \mathrm{mg} / \mathrm{L}$ stimulated radicle elongation while concentrations greater or equal to $3 \mathrm{mg} / \mathrm{L}$ caused severe toxicity (Kaplan et al, 1990).

The millet study by Wang (1985b) was expanded to include cucumber and lettuce seeds tested alongside millet in exposures to these same compounds (Wang, 1986). Millet was found to show a more regular and predictable response to the phenolics than the other two species, which are species recommended by the U.S. EPA and the OECD. Although the lettuce controls 
showed the most uniform root elongation, millet was as sensitive or more sensitive than the other two species and had the most predictable response.

Wang (1987) continued his development of the root elongation test by exposing lettuce, cucumber, and millet seeds to heavy metals (Cd, $\mathrm{Cr}$ (IV), Cu, $\mathrm{Mn}, \mathrm{Ni}$, and $\mathrm{Zn}$ ). Lettuce seeds were found to have the highest germination rate, the least variability, and the greatest sensitivity to heavy metal exposure. Millet seeds showed the most consistent response to toxicity. Cu or Ni were found to be the most toxic of the metals tested to cucumber and millet seeds, while Ni was the most toxic to lettuce. Cd was generally the third most toxic heavy metal to all three species. High variability was found as for the previous study, and is considered a characteristic of the root elongation test, since each seed can vary independently from 0 to more than $100 \mathrm{~mm}$, in contrast to the dichotomy of lethality tests.

In a test using root elongation of millet exposed to a series of heavy metals, Wang and Elseth (1990) found the three most toxic metals to be $\mathrm{Cu}, \mathrm{Ni}$, and $\mathrm{Cd}$, in that order. The NOEC values were $0.6,0.9$, and $2.6 \mathrm{mg} / \mathrm{L}$ respectively. In comparisons of these values with those found in other toxicity tests in the literature, the rye grass tests of Wong and Bradshaw (1982) were more sensitive than millet, duckweed, and fish.

Using root elongation tests in rye grass (Lolium perenne) as an endpoint of exposure to 10 metals, (Wong and Bradshaw, 1982) found that the most toxic metal was $\mathrm{Cu}$ and the least toxic was $\mathrm{Fe}$. Nickel was the second most toxic metal. Root elongation was more sensitive to metals than shoot growth in all cases because heavy metals must pass through the roots before they can have an effect on the shoot portion of the plant. No clear relationship was found between seed germination and the primary effects of metals on rooting, except that effects seen were seen only at concentrations above those critical for rooting.

The root system of Asparagus officinalis was also more sensitive than the shoots to diuron (Castanon, 1990). 
In a study evaluating the effects of beryllium and vanadium on collards, it was found that $97 \%$ of the Be taken up by the plants remained in the roots while only only $3 \%$ was translocated into the above ground parts of the plant (Kaplan et al, 1990). Be had a detrimental effect on germination but $V$ did not.

As seen in the present study, in petri dishes, roots do not grow straight but rather they become intertwined and twisted. Many researchers have germinated seed on an inclined or vertical plane to encourage straighter root growth. Edwards and Ross-Todd (1980) used plexiglass chambers with depressions to hold the seeds. The vertical surface allowed straight radical growth and even spacing of seeds allow the roots to grow separately, allowing for easy measurement. Many more seeds were able to be accomodated than in dishes. Gorsuch et al (1990) developed a similar method for allowing roots to germinate in the vertical plane, using separator racks and seed-pack growth pouches. They found lettuce to be the most sensitive species (of lettuce, radish, and ryegrass), and root elongation to be the most sensitive endpoint of those tested. Germination was not noticeably affected by the exposure to 26 commercial chemicals. In another study acrylic plastic boxes were partioned and filled with soil (Teem et al, 1973). Boxes were tilted at $18^{\circ}$ and covered with aluminum foil. Seeds were germinated in petri dishes and added to the compartments radicle side down.

The Neubauer technique, a method often used for evaluating the effect of fertilizers and to evaluate seed germination and growth has been modified for use in assessing contaminated soils (Thomas and Cline, 1985). Essentially the setup consists of petri dishes which are filled with soil, to which seeds are added and then watered with the treatment liquids. The whole system is then surrounded by a polyethylene bag filled with air and closed at the top. Germination and shoot measurements are taken through the bag, minimizing researcher exposure to the contaminants. In a study using samples from an abandoned waste pond, these researchers found germination to be slightly more sensitive than shoot growth.

Shoot growth has been measured in some studies, although it has generally been found to be less sensitive than root growth. Plant height of sorghum (Sorghum bicolor) and pinto bean (Phaseolus vulgaris), was used as an 
indicator of exposure to soil contaminated with jet fuel or the herbicide Krovar. In the jet fuel tests, plant height was stimulated in the dicotyledon (pinto bean) but not in the monocotyledon (sorghum) (Lillie and Bartine, 1990). They suggested that it may be important to include both types of plant in a bioassay.

In a study of the effect of nickel on rye grass, it was found that nickel depressed shoot yield at all levels except the lowest (30ug Ni/g soil) (Khalid and Tinsley, 1980). The increase of nickel concentration in the shoots was not proportional to the reduction in yield, nickel uptake being highest at the middle level and decreasing on both sides.

In tests using millet, radish (Raphanus sativus), and velvetleaf (Abutilon theophiasti) exposed to phenolic compounds, Wang (1985a) found that millet was generally the most sensitive. However, in comparison with daphnid, fathead minnows, bacteria, millet was found to be approximately one order of magnitude less sensitive. The endpoint used in the seed tests was growth rate.

There are a variety of other methods of plant bioassay including chlorophyll content, ion accumulation, and delayed fluorescence (Velagaleti et al, 1990) but they will not be discussed here. In addition to tests with xenobiotics bioassays similar to these can be used in tests using toxic metabolites from fungi (Wedge et al, 1993), allelochemics (Patterson, 1986), and other naturally occurring phytotoxic compounds (Duke, 1986).

Bioassays using seeds have in general been found to be simple and economical, making them ideal for screening large numbers of samples and compounds (Wang, 1985a). Seeds are usually dry and dormant and thus have a long shelf life yet are readily available. There are benefits and disadvantages to using each of the endpoints. The biomass method of seed germination is less time consuming and shows less variation than the root elongation method but the latter is more sensitive (Wang, 1985b, Edwards and Ross-Todd, 1980). Measuring of roots and shoots is the most time consuming part of most germination and root elongation studies (Gorsuch et al, 1990), however inhibition of root growth is one of the most rapid resposes to heavy metal exposure (Wong and Bradshaw, 1982). Root elongation will be tested in part 
two of this study and promises to be a sensitive endpoint of contaminant exposure in wetland species.

\section{CONTAMINANTS USED IN THIS STUDY}

Five contaminants (atrazine, anthracene, tetrachlorolethlene, nickel, and cadium) were used in the initial screening tests. Their effects are summarized separately below.

Atrazine (6-chloro- $\mathrm{N}$-ethyl-- $\mathrm{N}^{\prime}$-[1-methylethyl]-1,3,5-triazine-2,4-diamine) is an inhibitor of photosynthetic electron transport among susceptible plants( Kleier and Gardner 1993). Some species such as corn (Zea mays) are able to metabolically detoxify atrazine. For this reason atrazine is commonly used to selectively control dicotyledonous weeds in corn (Bartley, 1993). In fact, atrazine is the most heavily used agricultural pesticide in North America. In the USA more than 50 million $\mathrm{kg}$ are applied annually to more than 25 million ha. Residues in runoff from fields has been found in groundwater, lakes, and streams, sometimes at phytotoxic concentrations (Eisler, 1989).

Anthracene is a polycyclic aromatic hydrocarbon consisting of three annelated aromatic rings. It occurs from the incomplete burning of a number of substances including petroleum, coal, soot, and tar. Anthracene itself is not carcinogenic but many of its derivatives are (Williams and Weisburger, 1986).

Tetrachloroethylene is a halogenated hydrocarbon and is used for dry cleaning fabrics and for metal-degreasing operations. It is also used as an intermediate in the production of other chemicals. It has been found on at least 714 of the 1300 sites on the EPA's national priority list (USDHHS, 1990).

Cadmium is used in a number of industrial processes including electroplating and galvanizing. It is used as a color pigment in paints and plastic and as a cathode material in batteries. As a byproduct of zinc and lead mining and smelting it has become an important source of environmental contamination (Goyer, 1986). Compared with other metals cadmium is relatively mobile in the aquatic environment, and is transported in solution as either hydrated cations or 
organic or inorganic complexes. It is strongly accumulated by organisms at all trophic levels (USEPA, 1979).

Nickel is a metal whose properties make it very useful for combining with other metals to make alloys. It is used for nickel plating, to color ceramics, to make some batteries, and as a catalyst in chemical reactions. Release into the atmosphere occurs as a result of oil and coal burning power plants and incinerators (USDHHS, 1989). Nickel is discharged into waters through municipal wastewaters, smelting and refining of nonferrous metals, manufacturing processes, and atmospheric fallout (Nriagu and Pacyna, 1988).

\section{METHODS}

There were three main components to this study. The first was the collection and identification of herbaceous and woody species growing in Carolina Bays at the Savannah River Site. Seeds from these species were either collected or ordered from commercial sources as appropriate. Finally five toxicants were selected and the seeds were exposed to seven concentrations of each toxicant . Seed germination and root elongation were the endpoints measured. In addition to the wetland species, radish (Raphanus sativus), lettuce (Lactuca sativa), and white millet (Panicum miliaceum) were used in these tests. Radish and lettuce have been frequently used in seed germination and root elongation tests previously and served as control species, while millet, a native wetland species has previously been found to show a predictable response to contaminants (Wang, 1985b).

\section{SEED COLLECTION AND IDENTIFICATION}

Herbaceous species seeds were collected from various locations on the Savannah River Site and elsewhere from late July to mid-September of 1994. At SRS a number of Carolina Bays were visited. At each bay a survey of species present was made, using the references listed below. In some cases the help of experts in plant identification were enlisted. Especially helpful were Dr. Gary Wein at the Savannah River Ecology Laboratory and Phil Hyatt from the Forest Service station at SRS. The following lists the specific bays visited 
and the species found there (woody species included). An asterisk indicates seeds were collected.

Thunder Bay (Bay 83) 07/12/94 and 07/13/94

Acer rubrum

Eleocharis quadrangulata

Nymphaea odorata Eleocharis spp.(englemannis/ambigens) *

Quercus nigra Cyperus spp.

Panicum anceps Pinus taeda

Cornus spp. Brasenia schrekeri

Persea borbonia Liquidambar styraciflua

Panicum hemitomon Scirpus cyperinus *

Prosepinaca pectinata

Utricularia spp.

Lersia hexandra

Juncus spp. (immature)

Dry Bay (Bay 31) 07/12/94 and 07/13/94

Juncus effusus *

Hydrocotyl umbellata

Cephalanthus occidentalis *

Taxodium distichum

Craig's Pond (Bay 77) $07 / 28 / 94$ and 07/28/94

Scirpus cyperinus

Xyris caroliniana

Lachnanthes caroliniana *

Rhexia mariana

Rhyncospora tracyi *

Ellenton Bay (Bay 176) 07/19/94 and 07/20/94

Polygala spp.

Eleocharis quadrangulata*

Rhexia spp.

Nymphea odorata

Scirpus cyperinus

Panicum hemitomon

Panicum anceps

Brasenia schreberi

Carex glaucescens

Quercus nigra

Lycopus spp.

Liquidambar stryaciflua

Acer rubrum

Proserpinaca pectinata

Juncus effusus

Leersia hexandra* 
Compound 3 Bay \#1 (unable to ascertaine SRS Bay \#) 07/19/94 and 07/20/94 Cephalanthus occidentalis * Salix nigra

Rhyncospora inundata * Utricularia purpurea

Panicum hemitomon * Smilax rotunidfolia

Utricularia spp Scirpus cyperinus

Rhexia virginica Pontedaria cordata

Juncus validus

Compound 3 Bay \#2 07/19/94 and 07/20/94

Rhexia virginica

Scirpus cyperinus

${ }^{*}$ Species tested in laboratory

Seeds of herbaceous species were considered to be mature and were collected when they were dry, brown, and falling off of the plant. However, in many cases the seeds collected from SRS did not germinate, either because they were not ripe yet or we did not know the correct method for germinating them. While at a Wetland Horticulture course at Environmental Concern, St Michaels, MD, a number of seeds were obtained from species that were used in germination exercises during the course. Seeds from the following species were obtained from Environmental Concern:

Scirpus pungens

Verbena hastata

Scirpus validus

Carex crinata
Carex stricta

Scirpus robustus

Scirpus cyperinus

Pontedaria cordata

We were not able to germinate all of these seeds either.

Seeds of Nuphar luteum were obtained from Dr. Larry Dyck of the Biological Sciences Department in Clemson on 09/21/94.

Tree seeds were ordered from the International Forest Seed Company, PO Box 490, Simpson Rd., Odenville, AL, 35120. The following species were ordered: 
Fraxinus pennsylvanica

Quercus falcata var pagodifolia

Taxodium distichum

Nyssa aquatica

Diospyros virginiana

Quercus lyrata (green ash)

(southern red oak)

(bald cypress)

(water tupelo)

(common persimmon)

(overcup oak)

The overcup oak seeds germinated in the refrigerator and were therefore unusable. These seeds came preidentified by the Company.

Cephalanthus occidentalis seeds were collected on 09/24/94 from Lake Hartwell in Clemson, SC. These seeds were air dried for two days and then stored in the refrigerator as described below.

Saururus cernuus seeds were collected from Guntersville Reservoir, AL, on 09/16/94.

Lettuce, radish, and millet seeds were obtained from Griff's, a local feed and seed store in Pendleton, S.C.

After collection or receipt of seeds they were air dried and stored in plastic bags at $4^{\circ} \mathrm{C}$ (except radish and lettuce which were stored at room temperature). Some seeds were moist stratified in order to increase their germinability. Germination tests were carried out using filter paper in petri dishes in the germination chamber or a growth chamber. Specific germination enhancement treatment of the seeds of each species is detailed in the results section.

\section{INITIAL STOCK SOLUTION AND DILUTION PREPARATIONS}

\section{Stock Solution}

Stock solutions of each of the five compounds were made to a concentration of $1000 \mathrm{mg} / \mathrm{L}$ and $100 \mathrm{mg} / \mathrm{L}$. For nickel and cadmium (metalic state; zero valence state) atomic absorption spectrophotometer standards (AAS) were used at $1000 \mathrm{mg} / \mathrm{L}$. $100 \mathrm{mg} / \mathrm{L}$ stocks were made by adding $5 \mathrm{ml}$ of the AAS 
solutions to $45 \mathrm{ml}$ of double distilled water. Although the metals were in the zero valence state when they were applied to the filter pater they probably oxidized to the plus two state when they were exposed to air.

For the other three compounds, atrazine, anthracene, and tetrachloroethylene all stocks had to be made. All three of these substances have low solubility in water and thus the stock was made in methanol instead. Methanol controls were added in the experiment to test for the effects of methanol alone. Stocks were made in $100 \mathrm{ml}$ batches using volumetric flasks. The purity of each compound was taken into account in preparing the stock solutions.

\section{Dilution}

Concentrations to be tested were $0,0.1,0.5,1.0,5.0,10.0$, and $50.0 \mathrm{mg} / \mathrm{L}$. Originally lower concentrations were used but preliminary results indicated it would be better to test some higher concentrations in order to have definite responses.

Each day fresh stock solution of $10 \mathrm{ml}$ of $10 \mathrm{mg} / \mathrm{L}$ stock were prepared. The following chart shows how the dilutions were made:

\begin{tabular}{ccc} 
Final Conc. (mg/L) & Conc. of Stock Used & \multicolumn{2}{c}{ ml stock in $250 \mathrm{ml}$} \\
0.1 & $(\mathrm{mg} / \mathrm{L})$ & $\frac{\mathrm{milliQ} \text { water }}{2.5}$ \\
0.5 & 10 & 1.25 \\
1.0 & 100 & 2.5 \\
5.0 & 100 & 12.5 \\
10 & 100 & 2.5 \\
50 & 1000 & 12.5
\end{tabular}

To make the $10 \mathrm{mg} / \mathrm{L}$ temporary stock $1 \mathrm{ml}$ of $100 \mathrm{mg} / \mathrm{L}$ was added to a $10 \mathrm{ml}$ volumetric flask and brought to volume with milliQ (water that meets $18 \mathrm{ohm}$ resistance criteria) water. 
Each of the dilutions was made up by adding the required amount of stock to a $250 \mathrm{ml}$ volumetric flask which was then brought to volume with milliQ water. After mixing well the solutions were poured into $250 \mathrm{ml}$ jars with lids and then refrigerated. The volumetric flasks were washed well between each use and rinsed with dilute nitric acid or acetone as required.

An exception to the above was anthracene. It was not possible to dissolve it to a concentration of $1000 \mathrm{mg} / \mathrm{L}$ and therefore a $500 \mathrm{mg} / \mathrm{L}$ stock was made and $5 \mathrm{ml}$ and $25 \mathrm{ml}$ of this in $250 \mathrm{ml}$ milliQ water used to make the 10 and $50 \mathrm{mg} / \mathrm{L}$ solutions respectively.

Methanol controls were made as follows:

For the $0.5 \mathrm{mg} / \mathrm{L}$ standard, $1.25 \mathrm{ml}$ of methanol was added to the $250 \mathrm{ml}$ volumetric flask. This was brought up to $250 \mathrm{ml}$ with milliQ water. For the 5.0 standard, $12.5 \mathrm{ml}$ methanol was pipetted into the $250 \mathrm{ml}$ volumetric flask, and this was brought to volume $(250 \mathrm{ml})$ with milliQ water. For the highest methanol standard ( $25 \mathrm{mg} / \mathrm{L})$ which was necessary for the anthracene only (due to the fact that we had to use $500 \mathrm{mg} / \mathrm{L}$ stock instead of $1000 \mathrm{mg} / \mathrm{L}$ ), $25 \mathrm{ml}$ of methanol was pipetted into the $250 \mathrm{~m} /$ volumetric flask, which was then brought up to volume with milliQ water. Each of these was mixed well and decanted into $250 \mathrm{ml}$ jars for storage in the refrigerator.

Note that for all compounds except anthracene the $5.0 \mathrm{mg} / \mathrm{L}$ methanol standard is representative of the greatest amount of methanol the test solutions would have been exposed to, and this would have occurred in the $5 \mathrm{mg} / \mathrm{L}$ and $50 \mathrm{mg} / \mathrm{L}$ exposures.

The methanol controls were used as follows:

$\begin{array}{ccll}\frac{\mathrm{ml} \mathrm{MeOH} \text { in } 250 \mathrm{ml} \text { milliQ water }}{1.25} & \frac{\% \mathrm{MeOH}}{0.5 \%} & & \begin{array}{l}\text { control for } \\ 12.5\end{array} \\ 5.0 \% & 5.0 \mathrm{ppm} \text { atr, anth,PCE } \\ & & 50.0 \mathrm{ppm} \text { atr, }, \text { PCE } \\ 25.0 & 10.0 \% & 50.0 \mathrm{ppm} \text { anth }\end{array}$




\section{REVISED STOCK SOLUTION AND DILUTION PREPARATIONS}

The original method of using the methanol carrier had an effect on seed germination and root elongation, thus it confounded the results. Therefore, a revised method of mixing the chemicals was used to get the organic compound into solutions. A switch from the use of milliQ water to moderately hard water was made at this point also, to increase environmental representativeness.

All chemicals were made up in moderately hard water (MHW). MHW was made by autoclaving $12 \mathrm{~L}$ of MilliQ water and the following chemicals (wrapped separately in aluminum foil): $\mathrm{CaSO}_{4} .2 \mathrm{H}_{2} \mathrm{O}(0.72 \mathrm{~g}), \mathrm{NaHCO}_{3}(1.152 \mathrm{~g}), \mathrm{MgSO}_{4}$ $(0.72 \mathrm{~g})$ and $\mathrm{KCl}(0.048 \mathrm{~g})$. After the water had cooled the chemicals were added to the water in a $20 \mathrm{~L}$ carboy and mixed vigorously.

All bottles were washed appropriately and labelled with the date, chemical and its concentration, project number, and contact name.

The two metals (nickel and cadmium) were diluted from 1000ppm atomic absorption spectrophotometer standard solutions. No carrier was involved. The following dilutions were made:

\begin{tabular}{|c|c|c|}
\hline Solution wanted (ppm) & Stock used(ppm) & $\begin{array}{l}\text { ml stock added } \\
\text { to } 250 \mathrm{ml} \mathrm{MHWW}\end{array}$ \\
\hline 0.5 & 1000 & 0.125 \\
\hline 1.0 & 1000 & 0.25 \\
\hline 5.0 & 1000 & 1.25 \\
\hline 10.0 & 1000 & 2.5 \\
\hline 25.0 & 1000 & 6.25 \\
\hline 50.0 & 1000 & 12.5 \\
\hline
\end{tabular}

Each dilution was made using a $250 \mathrm{ml}$ volumetric flask.

Anthracene (99\% pure) stock was made up to a $1000 \mathrm{ppm}$ concentration $(0.025 \mathrm{~g}$ in $25 \mathrm{ml}$ methanol). It was attempted to make a 2000ppm stock but it would not dissolve, even with sonication. Dilutions to the various solutions were made as for the metals. 
Atrazine stock was made up to a $10,000 \mathrm{ppm}$ concentration by adding $0.257 \mathrm{~g}$ of $97.1 \%$ pure atrazine to $25 \mathrm{ml}$ methanol and sonicating.

Dilutions were made as follows:

\begin{tabular}{ccc} 
Solution wanted (ppm) & Stock used $(\mathrm{ppm})$ & $\frac{\mathrm{ml} \mathrm{stock} \text { added }}{250 \mathrm{ml} \mathrm{MHW}}$ \\
\cline { 2 - 3 } 0.5 & 1000 & 0.05 \\
1.0 & 1000 & 0.1 \\
5.0 & 10000 & 0.05 \\
10.0 & 10000 & 0.1 \\
25.0 & 10000 & 0.25 \\
50.0 & 10000 & 0.5
\end{tabular}

The 1000ppm stock was created by adding $1 \mathrm{ml}$ of the 10000ppm stock to a $10 \mathrm{ml}$ volumetric flask and bringing it to volume with MHW.

Tetracholorethylene (PCE) stock was made up to $10,000 \mathrm{ppm}$ by adding $1.0 \mathrm{~g}$ to a $100 \mathrm{ml}$ volumetric and bringing to volume with methanol. Dilutions were made as for atrazine.

The following methanol controls were made:

$\mathrm{ml} \mathrm{MeOH}$ in $250 \mathrm{ml} \mathrm{MHW}$

0.25

0.5

1.25

2.5

6.25

12.5
$\% \mathrm{MeOH}$

0.1

0.2

0.5

1.0

2.5

5.0 control for

25ppm atr, PCE

$1.0 \mathrm{ppm}$ anth $50 \mathrm{ppm}$ atr, PCE 5ppm anthr $10 \mathrm{ppm}$ anthr 25ppm anthr 50ppm anthr 
Treatment Design (For All Wetland Species Tests)

Five petri dishes of each contaminant at each concentration were labelled by species, date, contaminant, and concentration. Autoclaved filter paper was folded in quarters and laid in the dish, and $2.5 \mathrm{ml}$ of the toxicant was pipetted onto it. Seeds were surface sterilized with a $10 \%$ solution of bleach for 10 minutes then rinsed 5 times with distilled water. Floating seeds were removed, as were any that looked discolored or otherwise abnormal. Seeds were handled with tweezers. Five seeds of each species were placed in each dish with the following exceptions: 3 seeds each of Quecus falcata, 5 seed pairs of Cephalanthus occidentalis (since the seeds are paired).

Five replicates of each of the solutions were created, along with 5 replicates of milliQ water as a control. A separate set of 20 petri dishes containing one seed per dish treated with milliQ water was used to determine percent germination. Petri dishes were sealed with parafilm to prevent evaporation and petri dishes were randomly placed in the growth chamber. Growth chamber temperature measurements were taken with a portable thermometer and also continuously via chart recorder. The photoperiod was 14 hours light $\left(27^{\circ} \mathrm{C}\right)$ and 10 hours dark $\left(22^{\circ} \mathrm{C}\right)$.

Lettuce, Radish, and Millet Tests

Seeds of these three species were obtained from Griffs (Pendleton, SC). The seeds were bleached for $10 \mathrm{~min}$ in $10 \%$ bleach solution. Floating seeds were removed, as were any that were discolored. Five replicates of each of the solutions listed above were made as well as five replicates of MHW as a control. Each contained 5 seeds in a petri dish on filter paper that had been dosed with $5 \mathrm{ml}$ of each solution. In addition, 20 replicates of $5 \mathrm{ml} \mathrm{MHW}$ were made with one seed per petri dish in order to determine germination percent. Petri dishes were sealed with parafilm, and petri dishes were placed randomly in the growth chamber. Owing to space limitations the petri dishes were double stacked in a staggered fashion, such that light to the bottom layer of petri dishes was not blocked. The growth chamber was set for $27^{\circ} \mathrm{C}$ during the day (14hrs) and $22^{\circ} \mathrm{C}$ at night (10hrs). 
Measurements

Germination was recorded on the first day that radicles were seen and every second or third day afterwards depending on the rate of germination.

Cotyledon presence was also recorded. Cotyledons were counted as present after they had emerged from the seed coat and had separated from each other (sometimes the seed coat was still attached to the tip of one cotyledon).

Presence of fungi or algae was noted. Root lengths were estimated in incremental categories during germination. At the end of the test root lengths were measured with a ruler to obtain actual measurements. With some species additional developments were noted and measured, such as the length of the first shoot in Quercus falcata which has hypogeal germination, rather than epigeal germination as was seen in the other species (Young and Young, 1986).

Temperature in the growth chambers was recorded on a chart recorder and also at intervals on a portable thermometer during the tests.

\section{Statistics}

Data were entered into a computer using the Excel spreadsheet program. A second person double checked that data entry was correct. Graphs were made on Cricket Graph III. Means and standard deviations of each treatment were calculated using SAS. One way ANOVA and Tukey's Studentized Range (HSD) tests were also run using SAS.

\section{RESULTS}

The following species used in this study occur naturally on the Savannah River Plant site: Quercus falcata, Liquidambar styraciflua, Saururus cernuus, Cephalanthus occidentalis(Batson et al, 1985). Germination procedures of these species are detailed at the end of this section, along with those of some other species we have worked with. 
Seed Germination

Sweetgum (Liquidambar styraciflua)

A significant decrease in germination was seen in seedlings exposed to 50 ppm of both metals (Table 1 and Figures 1-5). With the three organic compounds, a significant decrease was seen at 5 and $50 \mathrm{ppm}$. This same decrease was seen in the $\mathrm{MeOH}$ control. As discussed under methods, in this test the 5 and $50 \mathrm{ppm}$ had the same concentration of $\mathrm{MeOH}$ carrier $(5 \%)$, whereas the $10 \mathrm{ppm}$ organics had only $1 \% \mathrm{MeOH}$ and did not show a significant decrease in seed germination.

White millet (Panicum miliaceum)

In this species no significant effect on seed germination was seen with exposure to PCE, nickel, and atrazine (T 2 and Figures 6-10). A significant decrease was seen with $50 \mathrm{ppm}$ cadmium and anthracene. The toxicity in the $50 \mathrm{ppm}$ anthracene exposure could be due to $\mathrm{MeOH}$ since a significant decrease was seen in the $5 \% \mathrm{MeOH}$ control, which was the amount of $\mathrm{MeOH}$ in the $50 \mathrm{ppm}$ anthracene treatment.

Cherry Belle radish (Raphanus sativus)

No effect on seed germination was seen from exposure to any of the contaminants (Table 3 and Figures 11-15).

Lizard's tail (Saururus cernuus)

A significant increase in seed germination was seen in seedlings exposed to 5 and 10 ppm nickel (Table 4 and Figures 16-20). Increases were also seen in $10 \mathrm{ppm}$ anthracene, $10 \mathrm{ppm} \mathrm{PCE}$, and the $0.5 \mathrm{ppm} \mathrm{MeOH}$ control (which corresponds to the amount of $\mathrm{MeOH}$ in $0.5 \mathrm{ppm}$ atrazine, anthracene, and PCE). A significant decrease in germination was found in seedlings exposed to $50 \mathrm{ppm}$ atrazine. 
Buttercrunch lettuce (Lactuca sativa)

No significant difference in seed germination was seen except in the $5 \%$ $\mathrm{MeOH}$ where a decrease was seen (Table 5 and Figures 21-25).

Cherrybark oak (Quercus falcata)

No significant changes in germination were seen except in the $50 \mathrm{ppm}$ nickel where a significant increase in germination was seen (Table 6 and Figures 26$30)$.

Buttonbush (Cephalanthus occidentalis)

Seedlings of this species exposed to 50ppm anthracene, 50ppm atrazine, $50 \mathrm{ppm}$ cadmium, and 50ppm nickel showed a significant decrease in germination (Tables 7 and 8 and Figures 31-35). In the 50ppm nickel and cadmium exposures no seedlings germinated.

\section{$\underline{\text { Root Elongation }}$}

Preliminary results are presented here. The rest will be presented with the final report of Part 2 of this study, along with the relevant statistics.

Radish (Raphanus sativus)

With exposure to nickel an overall decrease in root length was seen, with a slight increase at 1 and $5 \mathrm{ppm}$ (Table 9 and Figures 36-40). A similar pattern was seen with exposure to atrazine. An increase at 1ppm was seen with exposure to anthracene, followed by a sharp decrease in root length at the higher concentrations. Root length showed a steady decrease in response to cadmium exposure, while exposure to tetrachloroethylene resulted in a variable pattern of root length.

Cherrybark oak (Quercus falcata)

In seedlings exposed to tetrachloroethylene, nickel, and anthracene a general decreasing trend was seen, however the decrease in root length in 
anthracene exposed seedlings could have been due at least in part to the methanol carrier (Table 10 and Figures 41-45). Atrazine seemed to have little effect on germination except at the highest dose where a decrease was seen. In the cadmium exposure an increase in root length was seen at $25 \mathrm{ppm}$.

Buttercrunch lettuce (Lactuca sativa)

Roots of lettuce seedlings exposed to nickel and cadmium showed a decrease in root length at 5 and $10 \mathrm{ppm}$ respectively (Table 11 and Figures 4650). No change in root length was seen in seedlings exposed to tetrachloroethylene. Atrazine and anthracene exposure resulted in a trend of decreasing root length. In the atrazine test, root lengths were less than in the methanol controls suggesting that atrazine was the cause of the decrease.

Root elongation of buttonbush Cephanalthus occidentalis a appeared to be reduced by the highest concentrations of herbicides but the results were confounded by methanol effects at these concentrations (Tables 12 ; see page 16 of this report). Because of the confounding effects, it was not possible to clearly assess the toxic effects of these chemical on buttonbush root elongation. In contrast, root elongation of white millet Panicum miliaceum, was reduced by concentrations of nickel and cadmium at $25 \mathrm{ppm}$ and higher (Table 13). However, the effects of the herbicides on root elongation of white millet were less clear. Perchlorolethylene appeared to have no toxic effect at the concentrations tested whereas anthracene appeared to have toxic effects at 10 $\mathrm{ppm}$ and higher. The effect at $50 \mathrm{ppm}$ was again confounded with methanol effects (Table 13). Atrazine, on the other hand, showed inconsistent responses on white millet. It appeared to reduce root elongation slightly at $5 \mathrm{ppm}$ and greater but the effect at $5 \mathrm{ppm}$ were more pronounced than at 10 and $25 \mathrm{ppm}$.

\section{Comparison of Wild Species to Domestic Species}

Germination. Figures 51 and 52 show that germination of sweetgum (SG), buttonbush (BB), and lizard's tail (Liz-T) were affected more dramatically by 50 ppm of nickel and cadmium than cherrybark oak (CBO), radish (RAD), and millet (MILL). Of the domestic species, only millet (MILL) showed a significant effect of nickel and cadmium on germination. Both 10 and $50 \mathrm{ppm}$ of nickel and 
cadmium had an effect on germination of millet (MILL) whereas sweetgum (SG) and buttonbush (BB) appeared to respond only to $50 \mathrm{ppm}$ of either toxin. The response of lizard's tail (Liz-T) was not clear.

Root Elongation. Data were collected on only one wild species, cherrybark oak (CBO) and the results were unclear (Figures 53 and 54). In contrast, root elongation of millet (MILL) and lettuce (LET) was reduced by $5 \mathrm{ppm}$ or higher of nickel and $10 \mathrm{pmm}$ or higher of cadmium.

\section{DISCUSSION}

The results of Part 1 of this study suggest that seed germination is not very responsive to contaminant exposure except at high concentrations. It is also apparent that the agricultural species tested were more uniform in response, showed a higher percent germination, and germinated more quickly thus reducing problems with fungal contamination. However since agricultural species are not representative of species living in wetland environments and have been subjected to years of genetic manipulation they are not deemed appropriate as bioassay species for wetlands. Great care must be taken when using wetland species seeds in bioassays to assure that the seeds are as uniform as possible, have been properly stored and stratified if necessary, contain minimal fungus, and are viable. Young and Young (1986) is an excellent reference for most aspects of seed collection, storage, and germination in general. For specific species available information is often mimimal or non-existent; an exception to this are wetland trees species important to the forestry industry.

Factors that may play a role in seed tests other than that of the contaminants being tested include seed size, presence of and distance to neighbouring seeds, and maternal source. In Ludwigia leptocarpa seed size was found to have a significant effect on percentage germination and time of seed germination but not on dry weight or leaf area of seedlings (Dolan, 1984). When seeds of this species were grown together in pots, plants from larger seeds developed into larger plants. Plant size was significantly influenced not only by seed size but by the distance to three nearest neighbours. Thus seeds 


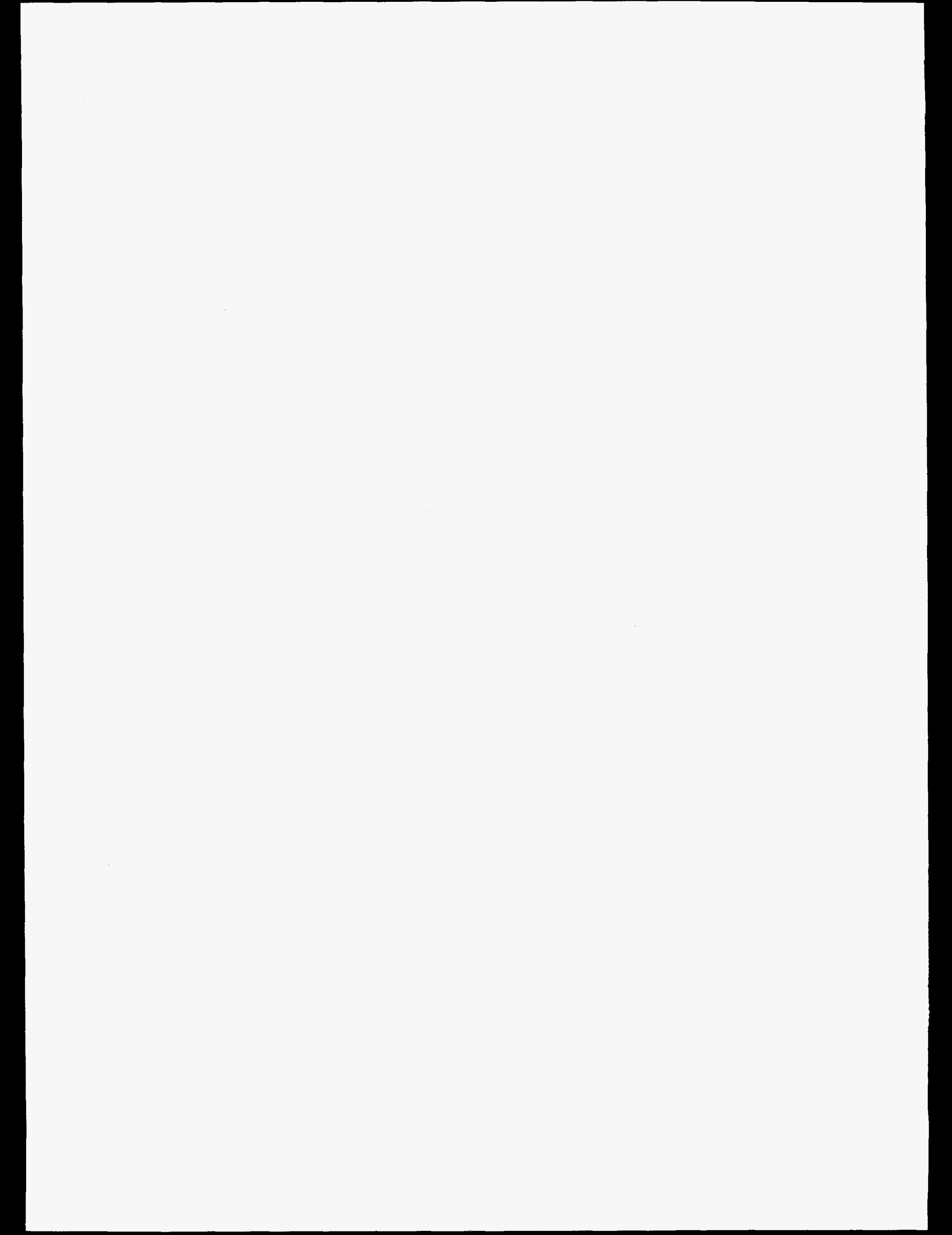


for toxicity tests need to be carefully chosen to be of similar size and appearance, and placed equidistant from each other in the test containers.

We recommend using more than one endpoint and more than one species when conducting phytotoxicity assays. Fletcher et al (1990) reported that taxonomic differences among plants had a much greater influence on plant response to chemical exposure than the difference between testing in the laboratory and the field. Wong and Bradshaw (1982) found from their and others results that the level at which the metals they tested became toxic varied greatly with species and appear to be related to specific ecological differences. In a computer search study using the PHYTOTOX database, Fletcher et al (1985) found oat and wheat to be the most sensitive species to the widest range of herbicides in comparison with 21 other commercial species. Radish was the third most sensitive dicotyledon. They concluded from their review of the literature that a species that is sensitive to one class of chemicals may not be sensitive to another, and therefore if the purpose of testing is to screen chemicals it is necessary to test a number of different species.

Using as many replicates as practical will increase statistical sensitivity. Edwards and Ross-Todd (1980) found a minimum of 150 seeds to be necessary to demonstrate a statistically significant difference in root growth at the lower concentrations that they tested.

We found that species with moderate sized seeds are generally easier to work with in toxicity tests. With small seeds, especially if a fine mist of condensation had formed on the petri dish lid, it was often very difficult to tell when germination had occurred. Large seeds (eg Quercus lyrata, a test that was aborted due to chamber malfunction) required larger petri dishes and took up more space in the chambers. In addition, it was difficult to maintain a high moisture content in the large pertri dishes with large seed. Even when sealed with parafilm, the large petri dishes tended to dry out and stop germination prematurely. If root elongation is categorized during the test as opposed to just at the end, as was done for several species (results not shown), it may be easier if a color other than white is used for the filter paper, as it makes seeing the roots much easier. Also in some species (eg Raphanus sativus), there was a tendency (not quantified) for a decrease in main root length to be compensated 
for by longer and more side roots. It was important in conducting a good test to apply sufficient sterilant to the seed to prevent fungus growth during the test without killing the seed and to start with seeds that were healthy and not contaminated with fungus, again to prevent fungus growth during the test. It may be useful to test stratifying the seeds in the various toxin combinations as this would more accurately simulate what would occur in field, and may increase the sensitivity of the germination test. Another way to more accurately represent field conditions is to test the seeds in various sand, vermiculite, and soil combinations, which is planned in Part 2 of this study.

Germination of wild species appeared to be more sensitive to nickel and cadmium than the domestic species. Of the domestic species, millet germination showed sensitivity to both nickel and cadmium whereas radish and lettuce showed no significant difference in germination at any toxin concentration. Under the test conditions of this experiment, millet was the only domestic species that could be used as a surrogate for wild species.

There was insufficent data to evaluate the test conditions on root elongation of wild species. However, root elongation of millet and lettuce were very sensitive to concentrations of both nickel and cadmium of 5 and $10 \mathrm{ppm}$ respectively. These results suggest that root elongation may be a better method of testing for toxins than germination, at least with domestic species.

The Fagaceae family (oaks, beeches, chestnuts) was represented in the test we conducted by only one species, cherrybark oak. This family is on the EPA and OECD's lists of recommended surrogate species and contains species that are abundant, widely distributed, and of economic importance (Fletcher et al, 1990). Attempts will be made to include more members of this family in Part 2 of this study. 


\title{
PRELEMINARY FINAL REPORT PART 2: \\ DEFINITIVE SEED GERMINATION \\ AND ROOT ELONGATION BIOASSAYS
}

\section{SPECIES}

\author{
METHODS
}

Eight species were used in Part two of this study. Four tree species were used; Liquidambar styraciflua (sweetgum), Fraxinus pennsylvanica (green ash), Pinus taeda (loblolly pine), and Quercus falcata var. pagodaefolia (cherrybark oak). One shrub, Cephalanthus occidentalis (buttonbush) was tested. These five species are all indigenous to wetlands of the southeastern United States. In addition, three agricultural species were tested; Lactuca sativa (lettuce), and Raphanus sativus (radish), and Panicum miliaceum (white millet). Radish and lettuce have been used in seed germination and root elongation tests previously and served as control species, while millet, a native wetland species, has previously been found to show a predictable response to contaminants (Wang, 1985b).

Tree seeds were ordered from the International Forest Seed Company, PO Box 490, Simpson Rd., Odenville, AL, 35120. Cephalanthus occidentalis seeds were collected on 09/24/94 from Lake Hartwell in Clemson, SC. These seeds were air dried for two days and stored in the refrigerator as described below. Lettuce, radish, and millet seeds were obtained from Griff's, a local feed and seed store in Pendleton, S.C. After collection or receipt of seeds they were air dried and stored in plastic bags at $4^{\circ} \mathrm{C}$. Some seeds (loblolly pine, sweetgum, green ash) were moist stratified in order to increase their germination.

\section{TOXICANTS AND TREATMENT OF SAND}

Stock solutions of cadmium and nickel were made using $\mathrm{CdCl}_{2}$ and $\mathrm{NiCl}_{2} 6 \mathrm{H}_{2} \mathrm{O}$. $1.64 \mathrm{~g}$ of $\mathrm{CdCl}_{2}$ or $4.05 \mathrm{~g}$ of $\mathrm{NiCl}_{2} \cdot 6 \mathrm{H}_{2} \mathrm{O}$ were disolved in $1 \mathrm{~L}$ of double distilled water in a $1 \mathrm{~L}$ volumetric flask and mixed well to make a $1000 \mathrm{mg} / \mathrm{L}$ solution. This 
solution was transferred to storage jars and stored in a refrigerator until used for treating the sand.

The growth media was sand that had been acid washed in $10 \% \mathrm{HNO}_{3}$ for at least 24 hours. The acid washed sand was rinsed in distilled water until the $\mathrm{pH}$ was equivalent to the $\mathrm{pH}$ of the distilled water. It was then autoclaved, and dried in a drying oven at $80^{\circ} \mathrm{C}$ for 24 hours.

Sand was treated using hand held sprayers containing a solution of toxicant in double distilled water. The amount of toxicant in the sprayer was calculated based on the weight of sand to be sprayed. Enough double distilled water was added to the sprayer such that the sand was completely wetted. Sand to be treated was spread evenly across a plastic sheet. After spraying, it was then transferred into a rubber tub and dried in an oven at $30^{\circ} \mathrm{C}$ until completely dry.

The concentrations of each metal used were $0,0.1,0.5,1.0,5.0,10.0,20.0$, and $40.0 \mathrm{mg} / \mathrm{L}$.

An example of calculations done for treating sand is as follows:

eg. You have 49lbs of sand available for treating, and want to make 4 different concentrations.

$\underline{49 \mathrm{lbs}}=22.3 \mathrm{~kg} \quad \underline{22.3 \mathrm{~kg}} \quad=5.57 \mathrm{~kg}$ per conc

$2.2 \mathrm{lbs} / \mathrm{kg} \quad 4$ concs to be made

$5.57 \mathrm{~kg} /$ conc. $X 2.2 \mathrm{lbs} / \mathrm{kg}=12.25 \mathrm{lb}$ per concentration available (the large scale measured in pounds).

To make sand at, for example, $10 \mathrm{mg} / \mathrm{L}=10000 \mathrm{ng} / \mathrm{g}$, you

want $10000 \mathrm{ng}$ metal/g sand in $5570 \mathrm{~g}$ sand $=55,700,000 \mathrm{ng}$ metal needed The stock is $1000 \mathrm{ng} / \mathrm{ul}=1000 \mathrm{mg} / \mathrm{L}$

$55,700,000 \mathrm{ng}=55700 \mathrm{ul}=55.7 \mathrm{ml}$

$1000 \mathrm{ng} / \mathrm{ul}$ 
Therefore, add $55.7 \mathrm{ml}$ stock to $5.57 \mathrm{~kg}$ sand $(12.25 \mathrm{lb})$ for $10 \mathrm{ppm}$ metal in sand.

\begin{tabular}{lll} 
For other concentrations: & conc & ml stock needed \\
\hline 0.1 & 0.57 \\
0.5 & 2.79 \\
1 & 5.57 \\
5 & 27.9 \\
10 & 55.7 \\
20 & 111.4 \\
40 & 222.8
\end{tabular}

In each case the volume in the sprayer was brought up to $1 \mathrm{~L}$ with double distilled water. Control sand was sprayed with $1 \mathrm{~L}$ of double distilled water.

\section{GERMINATION}

Seeds were germinated in sand containing the same concentration of contaminant as would be present in the root elongation tube to which they were to be transferred. For each concentration of each contaminant, 10 seeds were placed in each of 3 replicate petri dishes. The one exception to this was Quercus falcata, in which case only 7 seeds were placed per dish. The sand was watered with $10 \%$ Hoaglands nutrient medium to field capacity prior to placement of the seeds in the dish. Dishes were wrapped with parafilm and placed in a germination chamber set at $15^{\circ} \mathrm{C}$ for $12 \mathrm{hrs}$ of darkness and $30^{\circ} \mathrm{C}$ for 12 hours of light. Germination was recorded daily for up to 10 days. Once enough plants had germinated in most of the treatments (ie at least 10 per treatment for most treatments) they were transferred to root elongation tubes. In the case of Cephalanthus occidentalis not enough plants germinated in the 20 and $40 \mathrm{mg} / \mathrm{L}$ treatments to transfer. 
The root elongation tube consisted of a $200 \times 25 \mathrm{~mm}$ test tube with the top $4 \mathrm{~cm}$ painted with black paint to prevent light penetration down the glass. This tube was inserted into a 10 inch section of pvc pipe that had also been painted black. The bottom of the pvc pipe was closed with a rubber stopper. Ten such tubes were bundled together for stability. Each of two growth chambers contained 53 of these bundles. Each bundle was given a letter or double letter designation. Each tube in each bundle was given a number from one to ten. This together with the growth chamber number made it possible to locate any given plant. The tubes were placed in the chambers at $30^{\circ}$ angles.

Each test tube was filled with sand to within $3 \mathrm{~cm}$ of the top. The sand was then watered with $20 \mathrm{~mL}$ of $10 \%$ Hoagland's plant nutrient medium, $\mathrm{pH}$ 6.6. This medium had been tested with the treated sand to ensure the $\mathrm{pH}$ would be between 5.5 and 6.5. One seed per test tube was then placed in the tube on the side opposite the label. About $1 \mathrm{~cm}$ of autoclaved vermiculite was then placed over the seed. Randomization was accomplished by pulling from a beaker pieces of paper on which each location in the growth chamber had been written. This location was recorded both on the test tube and on data sheets. The test tubes were then placed in the appropriate location in the chambers with the label side up, such that the root would grow along the bottom side of the test tube.

At weekly intervals after being planted in the root elongation tubes, each species was checked for growth and appearance, and watered with $5 \mathrm{ml}$ of $10 \%$ Hoagland's.

At the end of three weeks each species was harvested. Each plant was carefully washed free of the sand and verimiculite using distilled water and transferred to a labelled plastic bag. Notes were taken on whether the plant was alive or dead, and whether it appeared healthy or was chlorotic or necrotic. 
Root length and shoot length were measured. Root and shoot were separated, placed in separate paper bags and placed in a drying oven at $30^{\circ} \mathrm{C}$ ro 48 hours and weighed.

\section{RESULTS}

\section{SEED GERMINATION}

Six species were evaluated using the germination bioassay procedures described in Part 1. Species tested included buttonbush (CEOC), white millet (PAMI), sweetgum (SG), cherrybark oak (QUFA), loblolly pine (PITA), and green ash (FRPE). Each species was tested against eight concentrations of $\mathrm{Cd}$ and $\mathrm{Ni}(0,0.1,0.5,1.0,5.0,10.0,20.0$, and $40.0 \mathrm{mg} / \mathrm{L})$. Germination data were collected daily; the bioassay lasted ten days.

No evidence of a dose-response relationships were seen for QUFA, PITA, or FRPE to either Cd or Ni (Figures 55 - 60). Data from these tests suggest that seed germination is not significantly affected by the concentrations of $\mathrm{Cd}$ and $\mathrm{Ni}$ under these experimental conditions. The best dose-response relationship was seen with CEOC (Figures 61 \& 62). At concentrations greater than $10 \mathrm{mg} / \mathrm{L}$, both $\mathrm{Cd}$ and $\mathrm{Ni}$ significantly reduced seed germination during the 10-day bioassay. This reduction was statistically significant as measured using ANOVA $(P<0.001)$.

The response of LIST to metal burden was dose dependent for Cd (Figure 63). The results of this bioassay were not as apparent statistically as those with CEOC due to less seed germination in the controls than in the lower $\mathrm{Cd}$ concentrations. The trend, however, is apparent.. A similar, but not statistically significant, trend was observed for $\mathrm{Ni}$ (Figure 64).

These results support our earlier conclusions that seed germination may be a useful bioassay but that response differs widely among both species and toxicants. Statistical analyses of the data suggest that the overall performance of the bioassay may be improved by significantly increasing the number of seeds used in each treatment (eg. $n=50$ ). 


\section{STEM AND ROOT ELONGATION}

The results for stem and root elongation were for seed germinated in petri dishes on filter paper at seven dose concentrations and grown in test tubes filled with acid washed sand with the same dose concentration as they were germinated.

Preliminary results of stem and root elongation responses to nickel and cadmium chloride salts are shown in Tables 14-17 and Figures $65-68$. The tables for green stem and root lengths give the number of observations per dose and standard deviations for mean values. They also contain ANOVAs for stem and root measurements.

Stem and root elongation of $\mathrm{CBO}$ and PAMI varied significant between dose responses (Tables $14 \& 15$ ) but there were no differences in these parameter between dose responses for LASA and FRPE (Tables $16 \& 17$ ). The final stem lengths of cherrybark oak (CBO) and white millet (PAMI) were very sensitive to nickel and cadmium (Figures 65 \& 66). Concentrations of nickel and cadmium at $5 \mathrm{ppm}$ reduced the final stem lengths of these two species by 30 to $40 \%$. For instance, cherrybark oak (CBO) stem lengths at $5 \mathrm{ppm}$ nickel were $58 \%$, at 10 ppm $32 \%$, at 20 ppm $40 \%$, and at 40 ppm $33 \%$ of the control. Cadmium had similar effects: at 5 ppm stem lengths were $61 \%$, at $10 \mathrm{ppm} 43 \%$, at $20 \mathrm{ppm}$ $40 \%$, and at 40 ppm $24 \%$ of the control lengths. Stem lengths of letttuce (LASA) and green ash (FRPE) showed no response to the metals. Perhaps this was because there was little or no stem growth with controls or any concentration of metals for this species.

Root elongation responses occurred in cherrybark oak (CBO) and white millet (PAMI; Figures 67 \& 68). Although cherrybark oak (CBO) showed a significant reduction in root elongation with increased concentrations of nickel and cadmium in the sand, the differences were small and therefore less easy to discern. In contrast, white millet (PAMI) had almost $10 \mathrm{~cm}$ of root lengths in the control but only $3.4 \mathrm{~cm}$ with $5 \mathrm{ppm}$ nickel or higher concentration and $5.8 \mathrm{~cm}$ of length or less with 5 ppm cadmium or higher concentrations. Roots of lettuce (LASA) and green ash (FRPE) did not respond to the metals. Again this lack of response appears to be a lack of root growth in controls and at any 
concentration of metals for these species. In this preliminary run, stem and root lengths of a wild species (cherrybark oak--CBO) and a domestic species (white millet--PAMI) were both very sensitive to $5 \mathrm{ppm}$ metal concentrations or higher.

\section{LITERATURE CITED FOR PLANT IDENTIFICATION}

Aulbach-Smith, C.A. and S. J. de Kozlowski. 1990. Aquatic and Wetland Plants of South Carolina. South Carolina Aquatic Plant Management. Council. USA.

Army Corps of Engineers. 1977 Wetland Plants of the Eastern United States. North Atlantic Division, 90 Church St. New York, NY 10007. NADP 200-1-1.

Batson, W.T., J.S. Angerman, and J. T. Jones. 1985. Flora of the Savannah River Plant. An inventory of the vascular plants on the Savannah River plant, South Carolina. SRO-NERP-15.

Godfrey , R.K. and J.W. Wooten. 1979. Aquatic and Wetland Plants of the Southeastern United States: Monocotyledons. UGA Press, Athens, GA.

Godfrey, R.K. and J.W. Wooten. 1981. Aquatic and Wetland Plants of the Southeastern United States. Dicotyledons. UGA Press, Athens, GA.

Schalles, J.F., R.R. Sharitz, J. W. Gibbons, G.J. Leversee, and J.N. Knox. 1989. Carolina Bays of the Savannah River Plant. SRO-NERP-18

Radford, A.E., Ahles, H.E., Bell, C.R. 1968. Manual of the Vascular Flora of the Carolinas. UNC Press, Chapel Hill.

\section{GENERAL LITERATURE CITED}

Bartley, M.R. 1993. Assessment of herbicide selectivity. IN: Herbicide bioassays. J.C. Streibig and P. Kudsk, Eds. CRC Press, Boca Raton, pp57-74. 
Batson, W.T., J.S. Angerman, and J.T. Jones. 1985. Flora of the Savannah River Plant. An Inventory of the Vascular Plants on the Savannah River Plant, South Carolina. SRO-NERP-15

Castanon, M.L.G. 1990. Early flowering in seedlings of asparagus promoted by diuron and atrazine. IN: Plant Aging: Basic and Applied Approaches. R. Rodriguez et al, Eds. Plenum Press, New York. pp445-447.

Dolan,R.W. 1984. The effect of seed size and maternal source on individual size in a population of Ludwigia leptocarpa (Onagraceae). Amer. J. Bot. 71: $1302-1307$.

Duke, S.O. 1986. Naturally occurring chemical compounds as herbicides. IN: Research Methods in Weed Science. N.D. Camper, Ed. 3rd Edition, pp17-44.

Edwards, N.T. and B. M. Ross-Todd. 1980. An improved bioassay technique used in solid waste leachate phytotoxicity research. Environ. and Expt. Bot. 20: 31-38.

Egley, G.H., 1986. Weed seed germination and seedling establishment. IN: Research Methods in Weed Science. N.D. Camper, Ed. 3rd Edition. pp47-70.

Eisler, R. 1989. Atrazine hazards to fish, wildlife, and invertebrates: a synoptic review. US Fish Wild. Serv. Biol. Rep. 85(1.18). 53pp.

Fletcher, J.S, M.J. Muhitch, D.R. Vann, J.C. McFarlane, and F.E. Benenati. 1985. Phytotox database evaluation of surrogate plant species recommended by the U.S. Environmental Protection Agency and the Organization for Economic Cooperation and Development. Environ. Toxicol. Chem. 4:523-532.

Fletcher, J.S., F.L. Johnson, and J.C. McFarlane. 1990. Influence of greenhouse versus field testing and taxonomic differences on plant sensitivity to chemical treatment. Environ. Toxicol. Chem. 9:769-776.

Fletcher, J. 1991. Keynote speech: A brief overview of plant toxicity testing. IN: Plants for Toxicity Assessment: Second Volume. ASTM STP 1115, J.W. Gorsuch, W.R. Lower, W. Wang, and M.A. Lewis Eds. American Society for Testing and Materials, Philadelphia, pp 5-11.

Gorsuch, J.W., R.O. Kringle, and K.A. Robillard. 1990. Chemical effects on the germination and early growth of terrestrial plants. IN: Plants for Toxicity Assessment, ASTM STP 1091, W.Wang, J.W. Gorsuch, and W.R. Lower, Eds. American Society for Testing and Materials, Philadelphia, pp49-58. 
Goyer, R.A. 1986. Toxic effects of metals. IN: Casarett and Doull's Toxicology. The Basic Science of Poisons. C.D. Klassen, M.O. Amdur, and J. Doull, Eds. Macmillan Publishing Co. New York. pp582-635.

Jones, R.H. and R.R. Sharitz. 1989. Potential advantages and disadvantages of germinating early for trees in floodplain forests. Oecologia, 81:443449.

Jones, R.H. an R.R. Sharitz. 1990. Dynamics of advance regeneration in four South Carolina bottomland hardwood forests. Proc. of the 6th Biennial Southern Silviculture Research Conference. S.S. Coleman and D.G. Neary, Eds., pp567-578.

Kaplan, D.I., K.S. Sajwan, D.C. Adriano, and S. Gettier. 1990. Phytoavailability and toxicity of beryllium and vanadium. Water, Alr, and Soil Pollutl 53:203-212.

Khalid, B.Y. and J. Tinsley. 1980. Some effects of nickel toxicity on rye grass. Plant and Soil 55:139-144.

Kleier, D. A. and G. Gardner. 1993. Quantitiative structure activity relationships: Adding value to herbicide bioassays. In Herbicide Bioassays. (eds.) J. C. Streibig and P. Kudsk. p 75-98. CRC Press. Ann Arbor. 270 pp.

Lillie, T.H., and R.W. Bartine. 1990. Protocol for evaluating soil contaminated with fuel or herbicide. IN: Plants for Toxicity Assessment, ASTM STP 1091, W. Wang, J.W. Gorsuch, and W.R. Lower, Eds. American Society for Testing and Materials, Philadelphia. pp 198-203.

Linder, G., J.C. Greene, H. Ratsch, J. Nwosu, S. Smith, and D. Wilborn. 1990. Seed germination and root elongation toxicity tests in hazardous waste site evaluation: methods development and applications. IN: Plants for Toxicity Assessment, ASTM STP 1091, W. Wang, J.W. Gorsuch, and W.R. Lower, Eds. American Society for Testing and Materials, Philadelphia, p177-187.

Nriagu, J.O. and Pacyna, J.M. 1988. Quantitative assessment of worldwide contamination of air, water, and soil by trace metals. Nature, 333:134.

Patterson, D.T. 1986. Allelopathy. IN: Research Methods in Weed Science. N.D. Camper, Ed. 3rd Edition, Chapter IV

Teem, D.H., C. S. Hoveland, and G.A. Buchanan. 1973. Primary root elongation of three weed species. Weed Science 22: 47-50.

Thomas, J.M. and J. F. Cline. 1985. Modification of the Neubauer technique to assess toxicity of hazardous chemicals in soils. Environ. Toxicol. Chem. 4: 201-207. 
USEPA, 1979. Water Related Fate of 129 Priority Pollutants. Ch. 9. Cadmium. Vol. 1. EPA 440/4-79-029a. U.S. Environmental Protection Agency, Washington, D.C.

USDHHS, 1989. Toxicological profile for nickel. U.S. Department of Health and Human Services. TP-92/14. Atlanta, GA.

USDHHS, 1990. Toxicological profile for tetrachloroethylene. U.S. Department of Health and Human Services. TP-92/18. Atlanta, GA.

Van Assche, F. and H. Clijsters. 1990. Effects of metals on enzyme activity in plants. Plant, Cell, and Environ. 13:195-206.

Velagaleti, R.R., D. Kramer, S.S. Marsh, N.G. Reichenbach, and D.E. Fleischmann. 1990. Some approaches to rapid and pre-symptom diagnosis of chemical stress in plants. IN: Plants for Toxicity Assessment, ASTM STP 1091, W. Wang, J.W. Gorsuch, an d W.R. Lower. Eds, American Society for Testing and Materials, Philadelphia pp. 333-345.

Wang, W. 1985a. The use of plant seeds in toxicity tests of phenolic compounds. Environ. Int. 11;49-55.

Wang, W. 1985b. Use of millet root elongation for toxicity tests of phenolic compounds. Environ. Int. 11:95-98.

Wang, W. 1986. Comparative toxicology of phenolic compounds using root elongation method. Environ. Toxicol. Chem. 5:891-896.

Wang, W. 1987. Root elongation method for toxicity testing of organic and inorganic pollutants. Environ. Toxicol. Chem. 6:409-414.

Wang, W. and J.M. Williams. 1988. Screening and biomonitoring of industrial effluents using phytotoxicity tests. Environ. Toxicol. Chem. 7:645-652.

Wang, W. and G. Elseth. 1990. Millet root elongation in toxicological studies of heavy metals: a mathematical model. IN: Plants for Toxicity Assessment, ASTM STP 1091, W. Wang, J.W. Gorsuch, and W.R. Lower, Eds., American Society for Testing and Materials, Philadelphia, pp280-294.

Wedge, D.E., S.D. McElreath, and F.H. Tainter. 1993. Bioassay of toxic metabolites from fungi associated with dogwood anthracnose.38th Annual Southern Nurserymen's Association Research Conference Report.

Williams, G.M. and J.H. Weisburger. 1986. Chemical carcinogens. IN:Casarett and Doull's Toxicology. The Basic Science of Poisons. C.D. Klassen, M.O. Amdur, and J. Doull, Eds. Macmillan Publishing Co. New York. pp99-173. 
Wong, M.H. and A.D. Bradshaw. 1982. A comparison of the toxicity of heavy metals, using root elongation of rye grass, Lolium perenne. New Phytol. 91:255-261.

Young, J.A. and C.G. Young. 1986. Collecting, Processing, and Germinating Seeds of Wildland Plants. Timber Press, Portland, OR. 236pp. 
Table 1. Seed germination response of sweetgum (Liquidambar styraciflua) to a range of concentrations of various toxins. (*Original methanol carrier levels.)

\section{SWEETGUM}

\begin{tabular}{|c|c|c|c|c|}
\hline \multirow[b]{2}{*}{ TOXIN } & \multirow[b]{2}{*}{ DOSE } & \multicolumn{3}{|c|}{ GERMINATION } \\
\hline & & TUKEY'S & MEAN & STD DEV \\
\hline \multirow[t]{7}{*}{ Nickel } & 0.0 & $\bar{a}$ & 4.4 & 0.5 \\
\hline & 0.1 & a & 4.8 & 0.4 \\
\hline & 0.5 & $\mathbf{a}$ & 4.6 & 0.5 \\
\hline & 1.0 & $\mathbf{a}$ & 5.0 & 0.0 \\
\hline & 5.0 & $\mathbf{a}$ & 5.0 & 0.0 \\
\hline & 10.0 & a & 4.8 & 0.4 \\
\hline & 50.0 & $b$ & 2.6 & 1.1 \\
\hline \multirow[t]{7}{*}{ Cadmium } & 0.0 & a & 4.4 & 0.5 \\
\hline & 0.1 & a & 4.6 & 0.5 \\
\hline & 0.5 & a & 4.6 & 0.5 \\
\hline & 1.0 & $\mathbf{a}$ & 4.6 & 0.5 \\
\hline & 5.0 & $\mathbf{a}$ & 5.0 & 0.0 \\
\hline & 10.0 & $\mathbf{a}$ & 4.8 & 0.4 \\
\hline & 50.0 & b & 2.4 & 0.9 \\
\hline \multirow[t]{7}{*}{ Atrazine $*$} & 0.0 & a & 4.4 & 0.5 \\
\hline & 0.1 & a & 4.6 & 0.5 \\
\hline & 0.5 & a & 5.0 & 0.0 \\
\hline & 1.0 & a & 4.6 & 0.9 \\
\hline & 5.0 & $\mathrm{~b}$ & 0.0 & 0.0 \\
\hline & 10.0 & a & 5.0 & 0.0 \\
\hline & 50.0 & b & 0.8 & 1.8 \\
\hline \multirow[t]{7}{*}{ Perchloroethylene * } & 0.0 & $\bar{a}$ & 4.4 & 0.5 \\
\hline & 0.1 & $\mathbf{a}$ & 5.0 & 0.0 \\
\hline & 0.5 & a & 4.4 & 0.5 \\
\hline & 1.0 & $\mathbf{a}$ & 5.0 & 0.0 \\
\hline & 5.0 & b & 0.8 & 1.8 \\
\hline & 10.0 & $\mathbf{a}$ & 4.0 & 1.4 \\
\hline & 50.0 & b & 0.8 & 1.3 \\
\hline \multirow[t]{7}{*}{ Anthracene * } & 0.0 & $\bar{a}$ & 4.4 & 0.5 \\
\hline & 0.1 & $\mathrm{a}$ & 4.6 & 0.9 \\
\hline & 0.5 & $\mathbf{a}$ & 4.6 & 0.5 \\
\hline & 1.0 & a & 4.8 & 0.4 \\
\hline & 5.0 & b & 0.8 & 1.3 \\
\hline & 10.0 & a & 4.4 & 0.5 \\
\hline & 50.0 & b & 0.0 & 0.0 \\
\hline \multirow[t]{4}{*}{ Methanol } & 0.0 & $\bar{a}$ & 4.4 & 0.5 \\
\hline & 0.5 & $\mathbf{a}$ & 4.6 & 0.5 \\
\hline & 5.0 & $\mathrm{~b}$ & 0.0 & 0.0 \\
\hline & 10.0 & $\mathrm{~b}$ & 0.0 & 0.0 \\
\hline
\end{tabular}


Table 2. Seed germination response of white millet (Panicum miliaceum) to a range of concentrations of various toxins. (* Methanol carrier levels minimized.)

\section{WHITE MILLET}

\begin{tabular}{|c|c|c|c|c|c|}
\hline \multirow[b]{2}{*}{ TOXIN } & \multirow[b]{2}{*}{ DOSE } & \multicolumn{4}{|c|}{ GERMINATION } \\
\hline & & & JKEY'S & MEAN & STD DEV \\
\hline \multirow{7}{*}{ Nickel } & 0.0 & $\bar{a}$ & & 3.8 & 0.8 \\
\hline & 0.5 & $\mathbf{a}$ & & 4.8 & 0.4 \\
\hline & 1.0 & $\mathbf{a}$ & & 3.8 & 0.4 \\
\hline & 5.0 & $\mathbf{a}$ & & 3.6 & 1.5 \\
\hline & 10.0 & $\mathbf{a}$ & & 3.2 & 0.8 \\
\hline & 25.0 & a & & 3.8 & 0.8 \\
\hline & 50.0 & $\mathbf{a}$ & & 3.0 & 1.2 \\
\hline \multirow[t]{7}{*}{ Cadmium } & 0.0 & a & b & 3.8 & 0.8 \\
\hline & 0.5 & $\mathbf{a}$ & b & 3.8 & 1.3 \\
\hline & 1.0 & $\mathbf{a}$ & $b$ & 3.8 & 1.6 \\
\hline & 5.0 & $\mathbf{a}$ & & 4.4 & 0.9 \\
\hline & 10.0 & $\mathbf{a}$ & & 4.0 & 0.7 \\
\hline & 25.0 & $\mathbf{a}$ & $b$ & 3.2 & 1.9 \\
\hline & 50.0 & & b & 1.8 & 0.8 \\
\hline \multirow[t]{7}{*}{ Atrazine * } & 0.0 & $\bar{a}$ & & 3.8 & 0.8 \\
\hline & 0.5 & a & & 4.2 & 0.8 \\
\hline & 1.0 & $\mathbf{a}$ & & 3.2 & 1.6 \\
\hline & 5.0 & a & & 2.8 & 0.8 \\
\hline & 10.0 & $\mathrm{a}$ & & 3.0 & 1.0 \\
\hline & 25.0 & $\mathbf{a}$ & & 3.4 & 1.1 \\
\hline & 50.0 & $\mathbf{a}$ & & 3.0 & 1.4 \\
\hline \multirow[t]{7}{*}{ Perchloroethylene * } & 0.0 & $a$ & & 3.8 & 0.8 \\
\hline & 0.5 & $\mathrm{a}$ & & 4.0 & 1.0 \\
\hline & 1.0 & a & & 3.6 & 0.5 \\
\hline & 5.0 & $\mathrm{a}$ & & 3.4 & 1.5 \\
\hline & 10.0 & $\mathbf{a}$ & & 3.8 & 1.6 \\
\hline & 25.0 & a & & 3.4 & 1.1 \\
\hline & 50.0 & a & & 3.8 & 1.3 \\
\hline \multirow{7}{*}{ Anthracene * } & 0.0 & $a$ & & 3.8 & 0.8 \\
\hline & 0.5 & a & $\mathrm{b}$ & 3.4 & 1.1 \\
\hline & 1.0 & $\mathbf{a}$ & & 3.6 & 1.1 \\
\hline & 5.0 & $\mathbf{a}$ & & 3.6 & 1.7 \\
\hline & 10.0 & $\mathbf{a}$ & b & 2.8 & 0.8 \\
\hline & 25.0 & $\mathbf{a}$ & b & 2.8 & 0.8 \\
\hline & 50.0 & & $b$ & 1.2 & 1.3 \\
\hline \multirow{7}{*}{ Methanol } & 0.0 & $\bar{a}$ & & 3.8 & 0.8 \\
\hline & 0.1 & $\mathbf{a}$ & & 4.2 & 1.1 \\
\hline & 0.2 & $\mathbf{a}$ & & 3.0 & 1.0 \\
\hline & 0.5 & $\mathrm{a}$ & & 3.2 & 1.5 \\
\hline & 1.0 & $\mathrm{a}$ & & 3.0 & 1.4 \\
\hline & 2.5 & $\mathbf{a}$ & & 2.8 & 1.3 \\
\hline & 5.0 & & $b$ & 0.2 & 0.4 \\
\hline
\end{tabular}


Table 3. Seed germination response of Cherry Belle radish (Rhaphanus sativus var. Cherry Belle) to a range of concentrations of various toxins. (* Methanol carrier levels minimized.)

CHERRY BELLE RADISH

\begin{tabular}{|c|c|c|c|c|}
\hline \multirow[b]{2}{*}{ TOXIN } & \multirow[b]{2}{*}{ DOSE } & \multicolumn{3}{|c|}{ GERMINATION } \\
\hline & & TUKEY'S & MEAN & STD DEV \\
\hline \multirow{7}{*}{ Nickel } & 0.0 & a & 4.6 & 0.5 \\
\hline & 0.5 & $\mathbf{a}$ & 4.0 & 1.2 \\
\hline & 1.0 & a & 3.6 & 2.1 \\
\hline & 5.0 & a & 4.8 & 0.4 \\
\hline & 10.0 & a & 4.4 & 0.5 \\
\hline & 25.0 & a & 4.4 & 0.9 \\
\hline & 50.0 & $\mathrm{a}$ & 4.0 & 0.7 \\
\hline \multirow[t]{7}{*}{ Cadmium } & 0.0 & $\mathbf{a}$ & 4.6 & 0.5 \\
\hline & 0.5 & a & 5.0 & 0.0 \\
\hline & 1.0 & a & 4.6 & 0.5 \\
\hline & 5.0 & $\mathrm{a}$ & 3.6 & 2.2 \\
\hline & 10.0 & a & 4.6 & 0.9 \\
\hline & 25.0 & $\mathrm{a}$ & 5.0 & 0.0 \\
\hline & 50.0 & $\mathrm{a}$ & 4.0 & 1.0 \\
\hline \multirow[t]{7}{*}{ Atrazine * } & 0.0 & $\mathrm{a}$ & 4.6 & 0.5 \\
\hline & 0.5 & a & 4.4 & 0.5 \\
\hline & 1.0 & a & 4.6 & 0.5 \\
\hline & 5.0 & $\mathrm{a}$ & 4.8 & 0.4 \\
\hline & 10.0 & $\mathrm{a}$ & 4.6 & 0.9 \\
\hline & 25.0 & $\mathbf{a}$ & 4.2 & 0.8 \\
\hline & 50.0 & $\mathrm{a}$ & 4.6 & 0.5 \\
\hline \multirow[t]{7}{*}{ Perchloroethylene * } & 0.0 & $\bar{a}$ & 4.6 & 0.5 \\
\hline & 0.5 & $\mathrm{a}$ & 5.0 & 0.0 \\
\hline & 1.0 & a & 4.0 & 1.0 \\
\hline & 5.0 & a & 3.8 & 0.1 \\
\hline & 10.0 & a & 4.4 & 0.5 \\
\hline & 25.0 & a & 4.8 & 0.4 \\
\hline & 50.0 & $\mathrm{a}$ & 4.8 & 0.4 \\
\hline \multirow[t]{7}{*}{ Anthracene * } & 0.0 & $\bar{a}$ & 4.6 & 0.5 \\
\hline & 0.5 & a & 4.6 & 0.5 \\
\hline & 1.0 & a & 4.4 & 0.9 \\
\hline & 5.0 & a & 4.8 & 0.4 \\
\hline & 10.0 & a & 4.2 & 1.3 \\
\hline & 25.0 & a & 3.4 & 1.9 \\
\hline & 50.0 & $\mathrm{a}$ & 3.8 & 0.4 \\
\hline \multirow[t]{7}{*}{ Methanol } & 0.0 & $\bar{a}$ & 4.6 & 0.5 \\
\hline & 0.1 & $\mathrm{a}$ & 4.4 & 0.9 \\
\hline & 0.2 & $\mathrm{a}$ & 4.6 & 0.5 \\
\hline & 0.5 & a & 4.4 & 0.9 \\
\hline & 1.0 & $\mathbf{a}$ & 3.8 & 1.1 \\
\hline & 2.5 & a & 4.2 & 1.1 \\
\hline & 5.0 & a & 3.2 & 0.8 \\
\hline
\end{tabular}


Table 4. Seed germination response of lizard's tail (Saururus cernuus) to a range of concentrations of various toxins. ( ${ }^{*}$ Original methanol carrier levels.)

\section{LIZARD'S TAIL}

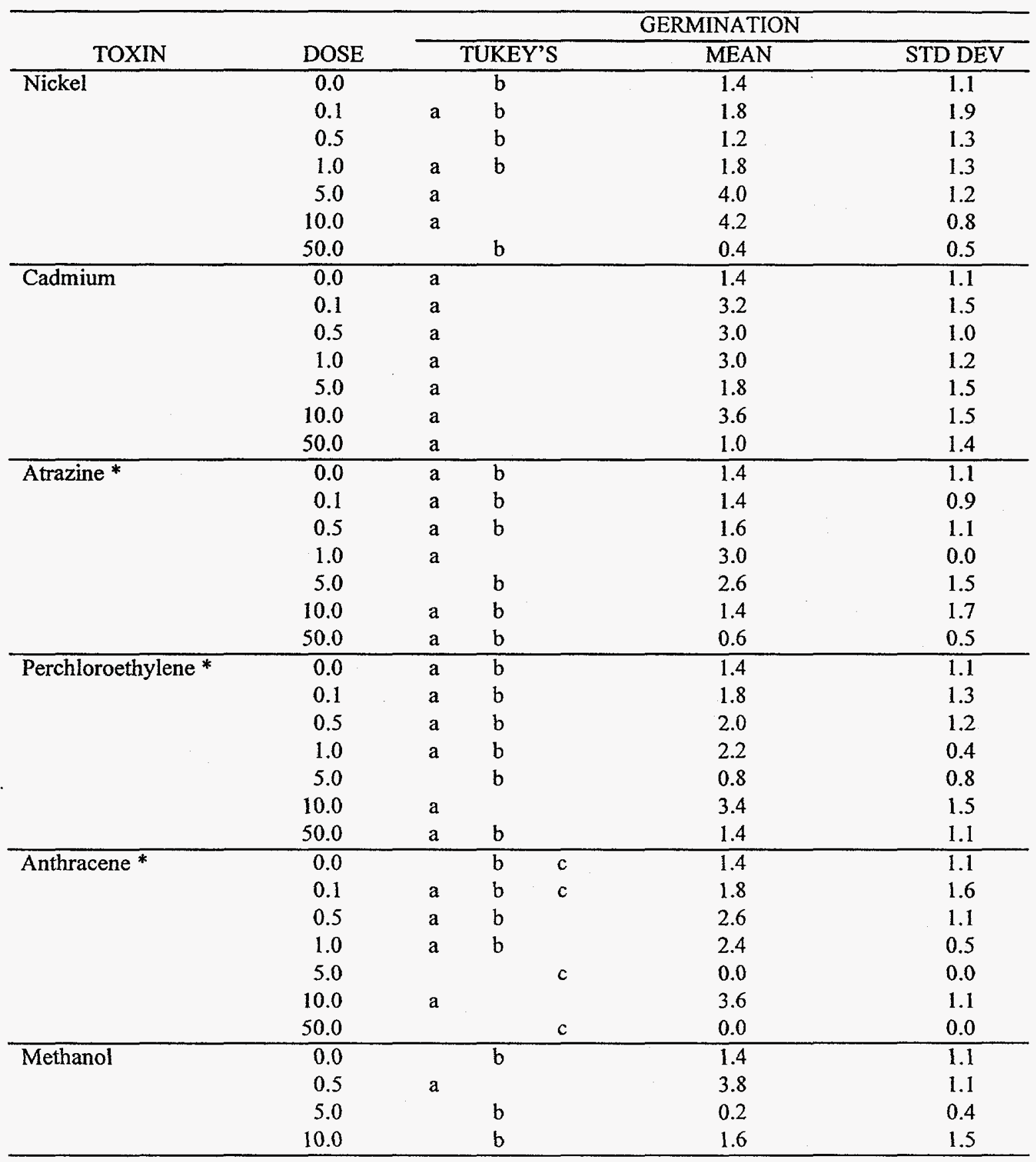


Table 5. Seed germination response of Buttercrunch lettuce (Lactuca sativa var. Buttercrunch) to a range of concentrations of various toxins. (* Methanol carrier levels minimized.)

\section{BUTTERCRUNCH LETTUCE}

\begin{tabular}{|c|c|c|c|c|}
\hline \multirow[b]{2}{*}{ TOXIN } & \multirow[b]{2}{*}{ DOSE } & \multicolumn{3}{|c|}{ GERMINATION } \\
\hline & & TUKEY'S & MEAN & STD DEV \\
\hline \multirow[t]{7}{*}{ Nickel } & 0.0 & $\mathbf{a}$ & 5.0 & 0.0 \\
\hline & 0.5 & a & 5.0 & 0.0 \\
\hline & 1.0 & $\mathbf{a}$ & 5.0 & 0.0 \\
\hline & 5.0 & $\mathbf{a}$ & 5.0 & 0.0 \\
\hline & 10.0 & a & 5.0 & 0.0 \\
\hline & 25.0 & a & 5.0 & 0.0 \\
\hline & 50.0 & $\mathbf{a}$ & 4.8 & 0.4 \\
\hline \multirow[t]{7}{*}{ Cadmium } & 0.0 & $\mathrm{a}$ & 5.0 & 0.0 \\
\hline & 0.5 & $\mathbf{a}$ & 5.0 & 0.0 \\
\hline & 1.0 & $\mathbf{a}$ & 5.0 & 0.0 \\
\hline & 5.0 & $\mathbf{a}$ & 5.0 & 0.0 \\
\hline & 10.0 & $\mathbf{a}$ & 5.0 & 0.0 \\
\hline & 25.0 & a & 5.0 & 0.0 \\
\hline & 50.0 & $\mathbf{a}$ & 5.0 & 0.0 \\
\hline \multirow[t]{7}{*}{ Atrazine * } & 0.0 & $\bar{a}$ & 5.0 & 0.0 \\
\hline & 0.5 & $\mathbf{a}$ & 5.0 & 0.0 \\
\hline & 1.0 & $\mathbf{a}$ & 5.0 & 0.0 \\
\hline & 5.0 & $\mathbf{a}$ & 5.0 & 0.0 \\
\hline & 10.0 & a & 5.0 & 0.0 \\
\hline & 25.0 & a & 4.8 & 0.4 \\
\hline & 50.0 & $\mathbf{a}$ & 5.0 & 0.0 \\
\hline \multirow[t]{7}{*}{ Perchloroethylene * } & 0.0 & $\mathbf{a}$ & $\overline{5.0}$ & 0.0 \\
\hline & 0.5 & a & 5.0 & 0.0 \\
\hline & 1.0 & $\mathbf{a}$ & 5.0 & 0.0 \\
\hline & 5.0 & $\mathbf{a}$ & 5.0 & 0.0 \\
\hline & 10.0 & $\mathbf{a}$ & 5.0 & 0.0 \\
\hline & 25.0 & a & 5.0 & 0.0 \\
\hline & 50.0 & $a$ & 5.0 & 0.0 \\
\hline \multirow[t]{7}{*}{ Anthracene * } & 0.0 & $\bar{a}$ & 5.0 & $\overline{0.0}$ \\
\hline & 0.5 & $\mathbf{a}$ & 5.0 & 0.0 \\
\hline & 1.0 & $\mathbf{a}$ & 5.0 & 0.0 \\
\hline & 5.0 & a & 5.0 & 0.0 \\
\hline & 10.0 & a & 5.0 & 0.0 \\
\hline & 25.0 & a & 5.0 & 0.0 \\
\hline & 50.0 & $\mathrm{a}$ & 4.6 & 0.9 \\
\hline \multirow[t]{7}{*}{ Methanol } & 0.0 & $\bar{a}$ & 5.0 & 0.0 \\
\hline & 0.1 & $\mathrm{a}$ & 5.0 & 0.0 \\
\hline & 0.2 & $\mathrm{a}$ & 5.0 & 0.0 \\
\hline & 0.5 & a & 5.0 & 0.0 \\
\hline & 1.0 & a & 5.0 & 0.0 \\
\hline & 2.5 & a & 5.0 & 0.0 \\
\hline & 5.0 & $\mathrm{a}$ & 4.4 & 0.5 \\
\hline
\end{tabular}


Table 6. Seed germination response of cherrybark oak ( $Q$ uercus falcata) to a range of concentrations of various toxins. (*With additional methanol control.)

\section{CHERRYBARK OAK}

\begin{tabular}{|c|c|c|c|c|}
\hline \multirow[b]{2}{*}{ TOXIN } & \multirow[b]{2}{*}{ DOSE } & \multicolumn{3}{|c|}{ GERMINATION } \\
\hline & & TUKEY'S & MEAN & STD DEV \\
\hline \multirow[t]{7}{*}{ Nickel } & 0.0 & $\mathrm{~b}$ & 0.6 & 0.5 \\
\hline & 0.1 & b & 0.8 & 0.8 \\
\hline & 0.5 & b & 0.0 & 0.0 \\
\hline & 1.0 & b & 0.4 & 0.5 \\
\hline & 5.0 & b & 0.6 & 1.3 \\
\hline & 10.0 & a & 1.2 & 0.4 \\
\hline & 50.0 & $\mathbf{a}$ & 2.4 & 0.9 \\
\hline \multirow[t]{7}{*}{ Cadmium } & 0.0 & $\bar{a}$ & 0.6 & 0.5 \\
\hline & 0.1 & $a$ & 1.4 & 1.1 \\
\hline & 0.5 & $\mathbf{a}$ & 1.0 & 0.7 \\
\hline & 1.0 & $\mathbf{a}$ & 0.8 & 0.8 \\
\hline & 5.0 & $\mathbf{a}$ & 1.4 & 0.5 \\
\hline & 10.0 & $\mathbf{a}$ & 0.4 & 0.5 \\
\hline & 50.0 & a & 1.0 & 1.4 \\
\hline \multirow[t]{7}{*}{ Atrazine } & 0.0 & $\mathbf{a}$ & 0.6 & 0.5 \\
\hline & 0.1 & $\mathbf{a}$ & 0.8 & 0.8 \\
\hline & 0.5 & $\mathrm{a}$ & 1.2 & 0.8 \\
\hline & 1.0 & a & 1.0 & 1.0 \\
\hline & 5.0 & $\mathbf{a}$ & 1.2 & 1.3 \\
\hline & 10.0 & $\mathbf{a}$ & 2.0 & 1.0 \\
\hline & 50.0 & a & 2.0 & 1.7 \\
\hline \multirow[t]{7}{*}{ Perchloroethylene } & 0.0 & $\bar{a}$ & 0.6 & 0.5 \\
\hline & 0.1 & $\mathbf{a}$ & 1.4 & 1.1 \\
\hline & 0.5 & $\mathbf{a}$ & 1.4 & 1.1 \\
\hline & 1.0 & $\mathbf{a}$ & 1.4 & 1.1 \\
\hline & 5.0 & a & 1.8 & 0.8 \\
\hline & 10.0 & $\mathbf{a}$ & 1.0 & 1.2 \\
\hline & 50.0 & $\mathbf{a}$ & 1.8 & 1.1 \\
\hline \multirow{7}{*}{ Anthracene } & 0.0 & $\mathbf{a}$ & 0.6 & 0.5 \\
\hline & 0.1 & a & 1.4 & 1.1 \\
\hline & 0.5 & a & 1.8 & 1.3 \\
\hline & 1.0 & a & 1.2 & 0.8 \\
\hline & 5.0 & $\mathrm{a}$ & 1.2 & 1.1 \\
\hline & 10.0 & $\mathrm{a}$ & 1.6 & 1.1 \\
\hline & 50.0 & $\mathrm{a}$ & 0.0 & 0.0 \\
\hline \multirow[t]{5}{*}{ Methanol * } & 0.0 & $\bar{a}$ & 0.6 & 0.5 \\
\hline & 0.5 & $\mathrm{a}$ & 0.8 & 0.8 \\
\hline & 1.0 & a & 0.4 & 0.9 \\
\hline & 5.0 & a & 0.2 & 0.4 \\
\hline & 10.0 & $\mathbf{a}$ & 0.0 & 0.0 \\
\hline
\end{tabular}


Table 7. Seed germination response of buttonbush (Cephalanthus occidentalis) to a range of concentrations of various toxins. (*Original methanol carrier levels.)

\section{BUTTONBUSH}

\begin{tabular}{|c|c|c|c|c|c|}
\hline \multirow[b]{2}{*}{ TOXIN } & \multirow[b]{2}{*}{ DOSE } & \multicolumn{4}{|c|}{ GERMINATION } \\
\hline & & & IUKEY'S & MEAN & STD DEV \\
\hline \multirow[t]{7}{*}{ Nickel } & 0.0 & $a$ & & 2.4 & 1.5 \\
\hline & 0.1 & a & & 2.6 & 1.3 \\
\hline & 0.5 & a & & 2.8 & 1.5 \\
\hline & 1.0 & a & & 3.8 & 0.4 \\
\hline & 5.0 & $\mathbf{a}$ & & 4.4 & 0.5 \\
\hline & 10.0 & a & & 3.2 & 0.8 \\
\hline & 50.0 & & b & 0.0 & 0.0 \\
\hline \multirow[t]{7}{*}{ Cadmium } & 0.0 & $\mathbf{a}$ & & 2.4 & 1.5 \\
\hline & 0.1 & $\mathbf{a}$ & & 3.2 & 0.8 \\
\hline & 0.5 & a & & 3.4 & 0.9 \\
\hline & 1.0 & a & & 2.6 & 1.3 \\
\hline & 5.0 & a & & 2.6 & 0.5 \\
\hline & 10.0 & a & & 3.6 & 0.5 \\
\hline & 50.0 & & b & 0.0 & 0.0 \\
\hline \multirow[t]{7}{*}{ Atrazine * } & 0.0 & $\bar{a}$ & $\mathrm{~b}$ & 2.4 & 1.5 \\
\hline & 0.1 & a & b & 2.8 & 0.8 \\
\hline & 0.5 & $\mathbf{a}$ & b & 3.0 & 1.2 \\
\hline & 1.0 & a & $b$ & 2.4 & 1.1 \\
\hline & 5.0 & $\mathbf{a}$ & b & 2.0 & 0.7 \\
\hline & 10.0 & a & & 3.4 & 0.9 \\
\hline & 50.0 & & $\mathrm{~b}$ & 0.8 & 1.3 \\
\hline \multirow[t]{7}{*}{ Perchloroethylene * } & 0.0 & $\bar{a}$ & & 2.4 & 1.5 \\
\hline & 0.1 & a & & 2.0 & 1.0 \\
\hline & 0.5 & a & & 3.4 & 0.9 \\
\hline & 1.0 & a & & 2.8 & 1.1 \\
\hline & 5.0 & $\mathbf{a}$ & & 2.0 & 1.6 \\
\hline & 10.0 & a & & 2.8 & 0.8 \\
\hline & 50.0 & $\mathrm{a}$ & & 3.0 & 1.9 \\
\hline \multirow[t]{7}{*}{ Anthracene ${ }^{*}$} & 0.0 & $\mathrm{a}$ & $\mathrm{b}$ & 2.4 & 1.5 \\
\hline & 0.1 & a & b & 2.6 & 1.1 \\
\hline & 0.5 & a & $b$ & 2.8 & 1.1 \\
\hline & 1.0 & a & & 3.8 & 0.8 \\
\hline & 5.0 & a & b & 2.8 & 1.3 \\
\hline & 10.0 & a & $b$ & 2.6 & 1.3 \\
\hline & 50.0 & & $b$ & 0.6 & 0.5 \\
\hline \multirow[t]{4}{*}{ Methanol } & 0.0 & $\bar{a}$ & $\mathrm{~b}$ & 2.4 & 1.5 \\
\hline & 0.5 & a & & 3.2 & 0.8 \\
\hline & 5.0 & $\mathrm{a}$ & $b$ & 2.0 & 0.7 \\
\hline & 10.0 & & b & 1.0 & 1.0 \\
\hline
\end{tabular}


Table 8. Seed germination response of buttonbush (Cephalanthus occidentalis) to a range of concentrations of various toxins, (*With additional methanol control.) (** Control data were derived from previous Cephalanthus experiment.)

\section{BUTTONBUSH}

\begin{tabular}{|c|c|c|c|c|}
\hline \multirow[b]{2}{*}{ TOXIN } & \multirow[b]{2}{*}{ DOSE } & \multicolumn{3}{|c|}{ GERMINATION } \\
\hline & & TUKEY'S & MEAN & STD DEV \\
\hline \multirow[t]{7}{*}{ Atrazine } & $0.0^{* *}$ & $\bar{a}$ & 2.4 & 1.5 \\
\hline & 0.1 & $\mathbf{a}$ & 4.0 & 0.7 \\
\hline & 0.5 & a & 3.6 & 0.5 \\
\hline & 1.0 & a & 4.0 & 0.7 \\
\hline & 5.0 & b & 1.8 & 1.3 \\
\hline & 10.0 & $\mathbf{a}$ & 3.8 & 0.8 \\
\hline & 50.0 & b & 1.8 & 1.3 \\
\hline \multirow[t]{7}{*}{ Perchloroethylene } & $0.0^{* *}$ & $\bar{a}$ & 2.4 & 1.5 \\
\hline & 0.1 & a & 4.4 & 0.5 \\
\hline & 0.5 & a & 3.8 & 1.1 \\
\hline & 1.0 & a & 4.2 & 0.8 \\
\hline & 5.0 & a & 3.4 & 0.5 \\
\hline & 10.0 & a & 4.0 & 0.7 \\
\hline & 50.0 & a & 3.2 & 1.3 \\
\hline \multirow[t]{7}{*}{ Anthracene } & $0.0^{* *}$ & $\bar{a}$ & 2.4 & 1.5 \\
\hline & 0.1 & $\mathbf{a}$ & 4.2 & 1.3 \\
\hline & 0.5 & a & 4.2 & 0.8 \\
\hline & 1.0 & $\mathbf{a}$ & 4.4 & 0.5 \\
\hline & 5.0 & a & 4.2 & 1.3 \\
\hline & 10.0 & a & 4.2 & 0.8 \\
\hline & 50.0 & b & 1.0 & 2.2 \\
\hline \multirow[t]{5}{*}{ Methanol * } & $0.0^{* *}$ & $\bar{a}$ & 2.4 & 1.5 \\
\hline & 0.5 & $\mathbf{a}$ & 3.6 & 1.7 \\
\hline & 1.0 & a & 3.0 & 1.0 \\
\hline & 5.0 & a & 1.8 & 1.3 \\
\hline & 10.0 & a & 1.2 & 1.6 \\
\hline
\end{tabular}


Table 9. Root elongation response of Cherry Belle radish (Rhaphanus sativus var. Cherry Belle) to various levels of toxins. (control data for final root measurements are missing.)

\section{CHERRY BELLE RADISH}

\begin{tabular}{|c|c|c|c|}
\hline \multirow[b]{2}{*}{ TOXIN } & \multirow[b]{2}{*}{ DOSE } & \multicolumn{2}{|c|}{ ROOT ELONGATION } \\
\hline & & MEAN & STD DEV \\
\hline \multirow[t]{7}{*}{ Nickel } & 0.0 & & \\
\hline & 0.5 & 5.5 & 3.9 \\
\hline & 1.0 & 6.1 & 3.4 \\
\hline & 5.0 & 6.8 & 2.5 \\
\hline & 10.0 & 3.7 & 2.6 \\
\hline & 25.0 & 2.4 & 1.4 \\
\hline & 50.0 & 0.2 & 0.3 \\
\hline \multirow[t]{7}{*}{ Cadmium } & 0.0 & & \\
\hline & 0.5 & 6.9 & 2.3 \\
\hline & 1.0 & 5.9 & 3.3 \\
\hline & 5.0 & 4.3 & 2.9 \\
\hline & 10.0 & 3.9 & 2.3 \\
\hline & 25.0 & 2.4 & 1.4 \\
\hline & 50.0 & 0.2 & 0.3 \\
\hline \multirow[t]{7}{*}{ Atrazine } & 0.0 & & \\
\hline & 0.5 & 5.6 & 3.6 \\
\hline & 1.0 & 6.2 & 3.8 \\
\hline & 5.0 & 6.2 & 3.2 \\
\hline & 10.0 & 5.4 & 2.7 \\
\hline & 25.0 & 5.1 & 3.7 \\
\hline & 50.0 & 4.1 & 3.0 \\
\hline \multirow[t]{7}{*}{ Perchloroethylene } & 0.0 & & \\
\hline & 0.5 & 5.9 & 3.4 \\
\hline & 1.0 & 6.5 & 3.7 \\
\hline & 5.0 & 5.7 & 3.9 \\
\hline & 10.0 & 6.5 & 3.8 \\
\hline & 25.0 & 5.9 & 3.0 \\
\hline & 50.0 & 5.5 & 3.4 \\
\hline \multirow[t]{7}{*}{ Anthracene } & 0.0 & & \\
\hline & 0.5 & 5.4 & 3.5 \\
\hline & 1.0 & 6.5 & 4.0 \\
\hline & 5.0 & 5.0 & 3.0 \\
\hline & 10.0 & 4.2 & 3.6 \\
\hline & 25.0 & 1.3 & 1.3 \\
\hline & 50.0 & 0.2 & \\
\hline \multirow[t]{7}{*}{ Methanol } & 0.0 & & \\
\hline & 0.1 & 5.6 & 3.5 \\
\hline & 0.2 & 5.7 & 3.2 \\
\hline & 0.5 & 5.2 & 3.6 \\
\hline & 1.0 & 4.2 & 3.5 \\
\hline & 2.5 & 1.8 & 1.4 \\
\hline & 5.0 & 1.4 & 0.1 \\
\hline
\end{tabular}


Table 10. Root elongation response of cherrybark oak (Quercus falcata) to various levels of toxins.

\section{CHERRYBARK OAK}

\begin{tabular}{|c|c|c|c|}
\hline \multirow[b]{2}{*}{ TOXIN } & \multirow[b]{2}{*}{ DOSE } & \multicolumn{2}{|c|}{ ROOT ELONGATION } \\
\hline & & MEAN & STD DEV \\
\hline \multirow[t]{7}{*}{ Nickel } & 0.0 & 1.5 & 3.3 \\
\hline & 0.5 & 2.7 & 5.7 \\
\hline & 1.0 & 0.8 & 2.2 \\
\hline & 5.0 & 0.4 & 1.4 \\
\hline & 10.0 & 0.7 & 2.6 \\
\hline & 25.0 & 2.1 & 3.4 \\
\hline & 50.0 & 1.6 & 1.3 \\
\hline \multirow[t]{7}{*}{ Cadmium } & 0.0 & 1.5 & 3.3 \\
\hline & 0.5 & 3.1 & 4.3 \\
\hline & 1.0 & 1.0 & 2.7 \\
\hline & 5.0 & 1.7 & 3.1 \\
\hline & 10.0 & 1.8 & 3.0 \\
\hline & 25.0 & 0.7 & 2.7 \\
\hline & 50.0 & 2.6 & 2.6 \\
\hline \multirow[t]{7}{*}{ Atrazine } & 0.0 & 1.5 & 3.3 \\
\hline & 0.5 & 0.6 & 1.5 \\
\hline & 1.0 & 1.8 & 3.1 \\
\hline & 5.0 & 1.9 & 3.0 \\
\hline & 10.0 & 1.9 & 3.2 \\
\hline & 25.0 & 4.3 & 5.0 \\
\hline & 50.0 & 0.7 & 1.1 \\
\hline \multirow[t]{7}{*}{ Perchloroethylene } & 0.0 & 1.5 & 3.3 \\
\hline & 0.1 & 2.6 & 3.8 \\
\hline & 0.5 & 2.3 & 3.4 \\
\hline & 1.0 & 1.5 & 2.3 \\
\hline & 5.0 & 2.2 & 3.6 \\
\hline & 10.0 & 0.2 & 0.5 \\
\hline & 50.0 & 0.6 & 1.3 \\
\hline \multirow[t]{7}{*}{ Anthracene } & 0.0 & 1.5 & 3.3 \\
\hline & 0.1 & 2.5 & 3.8 \\
\hline & 0.5 & 4.0 & 4.8 \\
\hline & 1.0 & 3.8 & 5.5 \\
\hline & 5.0 & 2.0 & 3.1 \\
\hline & 10.0 & 1.2 & 1.8 \\
\hline & 50.0 & 0.0 & 0.0 \\
\hline \multirow[t]{5}{*}{ Methanol } & 0.0 & 1.5 & 3.3 \\
\hline & 0.5 & 0.9 & 2.4 \\
\hline & 1.0 & 0.7 & 1.7 \\
\hline & 5.0 & 0.0 & 0.0 \\
\hline & 25.0 & 0.0 & 0.1 \\
\hline
\end{tabular}


Table 11. Root elongation response of Buttercrunch lettuce (Lactuca sativa var. Buttercrunch) to various levels of toxins.

\section{BUTTERCRUNCH LETTUCE}

\begin{tabular}{|c|c|c|c|}
\hline \multirow[b]{2}{*}{ TOXIN } & \multirow[b]{2}{*}{ DOSE } & \multicolumn{2}{|c|}{ ROOT ELONGATION } \\
\hline & & MEAN & STD DEV \\
\hline \multirow[t]{7}{*}{ Nickel } & 0.0 & 6.7 & 2.3 \\
\hline & 0.5 & 7.6 & 1.9 \\
\hline & 1.0 & 6.8 & 2.6 \\
\hline & 5.0 & 0.7 & 0.2 \\
\hline & 10.0 & 0.4 & 0.2 \\
\hline & 25.0 & 0.4 & 0.2 \\
\hline & 50.0 & 0.1 & .02 \\
\hline \multirow[t]{7}{*}{ Cadmium } & 0.0 & 6.7 & 2.3 \\
\hline & 0.5 & 7.4 & 1.8 \\
\hline & 1.0 & 7.4 & 1.3 \\
\hline & 5.0 & 6.0 & 1.2 \\
\hline & 10.0 & 2.8 & 0.8 \\
\hline & 25.0 & 0.3 & 0.3 \\
\hline & 50.0 & 0.1 & 0.02 \\
\hline \multirow[t]{7}{*}{ Atrazine } & 0.0 & 6.7 & 2.3 \\
\hline & 0.5 & 6.2 & 1.4 \\
\hline & 1.0 & 5.0 & 1.5 \\
\hline & 5.0 & 5.7 & 1.3 \\
\hline & 10.0 & 4.9 & 1.1 \\
\hline & 25.0 & 3.5 & 1.1 \\
\hline & 50.0 & 2.3 & 0.6 \\
\hline \multirow[t]{7}{*}{ Perchloroethylene } & 0.0 & 6.7 & 2.3 \\
\hline & 0.5 & 8.2 & 2.0 \\
\hline & 1.0 & 7.7 & 1.6 \\
\hline & 5.0 & 7.0 & 2.1 \\
\hline & 10.0 & 8.4 & 1.4 \\
\hline & 25.0 & 7.4 & 2.5 \\
\hline & 50.0 & 7.2 & 2.2 \\
\hline \multirow[t]{7}{*}{ Anthracene } & 0.0 & 6.7 & 2.3 \\
\hline & 0.5 & 8.1 & 2.0 \\
\hline & 1.0 & 8.9 & 2.2 \\
\hline & 5.0 & 7.3 & 1.5 \\
\hline & 10.0 & 4.5 & 1.7 \\
\hline & 25.0 & 0.5 & 0.4 \\
\hline & 50.0 & 0.1 & 0.2 \\
\hline \multirow[t]{7}{*}{ Methanol } & 0.0 & 6.7 & 2.3 \\
\hline & 0.1 & 7.8 & 1.6 \\
\hline & 0.2 & 7.2 & 2.6 \\
\hline & 0.5 & 7.5 & 2.5 \\
\hline & 1.0 & 6.3 & 1.9 \\
\hline & 2.5 & 0.7 & 0.5 \\
\hline & 5.0 & 0.1 & 0.05 \\
\hline
\end{tabular}


Table 12. Root elongation response of buttonbush (Cephalanthus occidentalis) to various levels of toxins. (Control data for final root measurements are missing.)

\section{BUTTONBUSH}

\begin{tabular}{|c|c|c|c|}
\hline \multirow[b]{2}{*}{ TOXIN } & \multirow[b]{2}{*}{ DOSE } & \multicolumn{2}{|c|}{ ROOT ELONGATION } \\
\hline & & MEAN & STD DEV \\
\hline \multirow[t]{7}{*}{ Atrazine } & 0.0 & ${ }^{0}$ & \\
\hline & 0.1 & 1.4 & 1.2 \\
\hline & 0.5 & 0.7 & 0.6 \\
\hline & 1.0 & 0.7 & 0.5 \\
\hline & 5.0 & 0.5 & 0.5 \\
\hline & 10.0 & 0.4 & 0.4 \\
\hline & 50.0 & 0.1 & 0.2 \\
\hline \multirow[t]{7}{*}{ Perchloroethylene } & 0.0 & - & 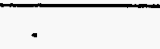 \\
\hline & 0.1 & 1.6 & 1.2 \\
\hline & 0.5 & 1.2 & 1.2 \\
\hline & 1.0 & 1.1 & 1.0 \\
\hline & 5.0 & 0.7 & 0.8 \\
\hline & 10.0 & 0.8 & 0.9 \\
\hline & 50.0 & 0.1 & 0.1 \\
\hline \multirow[t]{7}{*}{ Anthracene } & 0.0 & & . \\
\hline & 0.1 & 1.3 & 1.3 \\
\hline & 0.5 & 1.0 & 0.8 \\
\hline & 1.0 & 1.1 & 1.0 \\
\hline & 5.0 & 0.8 & 0.7 \\
\hline & 10.0 & 0.5 & 0.5 \\
\hline & 50.0 & 0.1 & 0.3 \\
\hline \multirow[t]{5}{*}{ Methanol } & 0.0 & . & \\
\hline & 0.5 & 1.1 & 1.1 \\
\hline & 1.0 & 0.7 & 0.8 \\
\hline & 5.0 & 0.0 & 0.1 \\
\hline & 25.0 & 0.0 & 0.0 \\
\hline
\end{tabular}


Table 13. Root elongation response of white millet (Panicum miliaceum) to various levels of toxins.

WHITE MILLET

\begin{tabular}{|c|c|c|c|}
\hline \multirow[b]{2}{*}{ TOXIN } & \multirow[b]{2}{*}{ DOSE } & \multicolumn{2}{|c|}{ ROOT ELONGATION } \\
\hline & & MEAN & STD DEV \\
\hline \multirow[t]{7}{*}{ Nickel } & 0.0 & 3.7 & 3.2 \\
\hline & 0.5 & 4.5 & 2.3 \\
\hline & 1.0 & 4.0 & 3.1 \\
\hline & 5.0 & 1.0 & 0.9 \\
\hline & 10.0 & 0.8 & 0.6 \\
\hline & 25.0 & 0.5 & 0.4 \\
\hline & 50.0 & 0.0 & 0.0 \\
\hline \multirow[t]{7}{*}{ Cadmium } & 0.0 & 3.7 & 3.2 \\
\hline & 0.5 & 3.5 & 3.1 \\
\hline & 1.0 & 3.6 & 3.2 \\
\hline & 5.0 & 3.0 & 2.5 \\
\hline & 10.0 & 2.0 & 1.9 \\
\hline & 25.0 & 0.2 & 0.3 \\
\hline & 50.0 & 0.0 & 0.0 \\
\hline \multirow[t]{7}{*}{ Atrazine } & 0.0 & 3.7 & 3.2 \\
\hline & 0.5 & 3.8 & 2.8 \\
\hline & 1.0 & 3.7 & 3.6 \\
\hline & 5.0 & 1.3 & 1.8 \\
\hline & 10.0 & 2.1 & 2.6 \\
\hline & 25.0 & 2.4 & 2.6 \\
\hline & 50.0 & 0.9 & 0.9 \\
\hline \multirow[t]{7}{*}{ Perchloroethylene } & 0.0 & 3.7 & 3.2 \\
\hline & 0.5 & 3.8 & 2.8 \\
\hline & 1.0 & 3.2 & 3.2 \\
\hline & 5.0 & 3.0 & 3.2 \\
\hline & 10.0 & 3.5 & 3.1 \\
\hline & 25.0 & 3.1 & 3.2 \\
\hline & 50.0 & 2.3 & 2.0 \\
\hline \multirow{7}{*}{ Anthracene } & 0.0 & 3.7 & 3.2 \\
\hline & 0.5 & 2.8 & 2.9 \\
\hline & 1.0 & 3.7 & 3.4 \\
\hline & 5.0 & 1.7 & 2.1 \\
\hline & 10.0 & 0.6 & 0.8 \\
\hline & 25.0 & 0.3 & 0.4 \\
\hline & 50.0 & 0.0 & 0.0 \\
\hline \multirow[t]{7}{*}{ Methanol } & 0.0 & 3.7 & 3.2 \\
\hline & 0.1 & 4.2 & 3.1 \\
\hline & 0.2 & 3.5 & 3.5 \\
\hline & 0.5 & 2.6 & 2.9 \\
\hline & 1.0 & 2.5 & 2.4 \\
\hline & 2.5 & 0.5 & 0.5 \\
\hline & 5.0 & 0.0 & 0.1 \\
\hline
\end{tabular}


Table 14 Stem and root elongation responses of cherrybark oak to nicket and cadmium dose rates

\begin{tabular}{|c|c|c|c|c|c|c|c|c|c|c|c|}
\hline \multirow{3}{*}{$\begin{array}{c}\mathrm{Ni} \\
\text { TOX }\end{array}$} & 2 & 3 & POOT & & GREEN & \multirow{2}{*}{$\begin{array}{l}\text { BIONASS } \\
\text { FINAL ROOT }\end{array}$} & & \multirow{2}{*}{ FAY } & \multirow[b]{2}{*}{ STEM } & \multirow{2}{*}{\begin{tabular}{|l|} 
BIONASS \\
FINAL \\
\end{tabular}} & \multirow{3}{*}{$\begin{array}{c}\text { POOT } \\
s\end{array}$} \\
\hline & INT & FINAL & SHAPE & \multicolumn{2}{|c|}{ FINAL STEM } & & & & & & \\
\hline & SUAV \% & SUAV $\%$ & s/c/ve & $\mathrm{cm}$ & 5 & $\mathrm{~cm}$ & 5 & $\mathrm{~cm}$ & 6 & $\mathrm{~cm}$ & \\
\hline 0 & 38 & 100 & & 7.72 & 3.8289 & 4.09 & 1.0743 & & & & \\
\hline 5 & 38 & 100 & & $4.5 t$ & 3.5202 & 3.57 & 0.6753 & & & & \\
\hline 10 & 15 & 100 & & 2.48 & 2.1398 & 2.60 & 0.8042 & & & & \\
\hline 20 & 8 & 100 & & 3.12 & 1.4473 & 3.35 & 2.0723 & & & & \\
\hline 40 & 15 & 100 & & 2.58 & 2.058 & 2.14 & 1.0038 & & & & \\
\hline \multirow[t]{2}{*}{$\infty$} & 2 & 3 & ROOT & & GREEN & BKOMASS & & DFY & & BIOMASS & \multirow{3}{*}{$\begin{array}{c}\text { ROOT } \\
6\end{array}$} \\
\hline & NT & FINAL & SHAPE & FINAL & STEM & FINAL & POOT & FINAL & SIEM & FINAL & \\
\hline TOX & SUAV \% & SUAV \% & s/c/ve & $\mathrm{cm}$ & 5 & $\mathrm{~cm}$ & 5 & $\mathrm{~cm}$ & 5 & $\mathrm{~cm}$ & \\
\hline 0 & 36 & 100 & & 7.72 & 3.9289 & 4.09 & 1.0743 & & & & \\
\hline 5 & 15 & 92 & & 4.36 & 3.4016 & 3.19 & 1.1041 & & & & \\
\hline 10 & 15 & 100 & & 3.31 & 2.7978 & 3.38 & 0.5732 & & & & \\
\hline 20 & 15 & 92 & & 3.14 & 2.3564 & 2.86 & 1.5956 & & & & \\
\hline 40 & 8 & 100 & & 1.60 & 2.0351 & 1.92 & 1.1374 & & & & \\
\hline
\end{tabular}

QUFA DOSE ANOVA NIckel FINAL STEMLENGTH (CM) DOSE

QUFA DOSE ANOVA

Nickel

FINAL ROOT LENGTH (CM)

$$
\text { DOSE }
$$

0

$\begin{array}{rrrr}5 & 10 & 20 & 40 \\ 90 & 3.10 & 10.00 & 1.80 \\ 30 & 4.70 & 2.50 & 1.90 \\ 50 & 2.10 & 1.90 & 2.30 \\ 50 & 2.00 & 2.80 & 0.30 \\ 70 & 2.80 & 2.60 & 2.70 \\ 00 & 3.40 & 2.30 & 1.90 \\ 90 & 2.40 & 3.40 & 3.40 \\ 10 & 1.50 & 2.60 & 3.00 \\ 30 & 2.80 & 3.20 & 0.60 \\ 70 & 2.60 & 3.90 & 2.00 \\ 90 & 2.80 & 2.50 & 1.30 \\ 40 & 2.60 & 3.40 & 3.40 \\ 30 & 3.60 & 2.40 & 3.20\end{array}$

Anova: Single-Factor

Summary

\section{Groups Count Sum Average Variance}

$\begin{array}{lrrrr}\text { Column 1 } & 13 & 100.3 & 7.7154 & 15.436 \\ \text { Column 2 } & 13 & 57.9 & 4.4538 & 11.398 \\ \text { Column 3 } & 13 & 32.2 & 2.4769 & 4.5786 \\ \text { Column 4 } & 13 & 40.5 & 3.1154 & 2.0947\end{array}$

Column 4

ANOVA

Source of Variation

\begin{tabular}{lrrrrrr} 
& SS & \multicolumn{1}{c}{$d f$} & MS & $F$ & $P$-value & $F$ crit \\
\hline Between Grouf 248.49 & 4 & 62.122 & 8.2297 & $2 E-05$ & 2.5252 \\
Within Groups & 452.91 & 60 & 7.5485 & & &
\end{tabular}

Within Groups $\mathbf{4 5 2 . 9 1}$

Total $\quad 701.4 \quad 64$

Anova: Single-Factor

Summary

Groups Count Sum Average Vaniance

$\begin{array}{lllll}\text { Column } 1 & 13 & 53.2 & 4.0923 & 1.1541\end{array}$

$\begin{array}{llllll}\text { Column 2 } & 13 & 46.5 & 3.5769 & 0.4186\end{array}$

$\begin{array}{lllll}\text { Column } 3 & 13 & 36.4 & 2.8 & 0.6467\end{array}$

$\begin{array}{llllll}\text { Column } 4 & 13 & 43.5 & 3.3462 & 4.2944\end{array}$

$\begin{array}{lllll}\text { Column } 5 & 13 & 27.8 & 2.1385 & 1.0076\end{array}$

ANOVA

Source of Varlation

\begin{tabular}{cccccccc} 
SS & df & MS & $F$ & $P$-valus & $F$ crit \\
\hline Belween Grouf 29.199 & & 4 & 7.2998 & 4.8527 & 0.0019 & 2.5252
\end{tabular}

Within Groups $90.255 \quad 60 \quad 1.5043$

Total $\quad 119.45 \quad 64$ 
Table 14 (contlnued

QUFA DOSE ANOVA

Cadmium

FINAL STEMLENGTH(CM)

$$
\text { DOSE }
$$

$\begin{array}{rrrrr}0 & 5 & 10 & 20 & 40 \\ 12.70 & 0.60 & 0.20 & 7.50 & 0.80 \\ 4.90 & 5.40 & 5.30 & 5.40 & 0.70 \\ 11.10 & 4.30 & 5.50 & 2.20 & 7.20 \\ 10.70 & 3.70 & 0.40 & 3.20 & 0.30 \\ 11.80 & 3.40 & 4.50 & 2.00 & 0.50 \\ 1.70 & 11.00 & 0.20 & 4.20 & 1.40 \\ 10.90 & 2.80 & 3.60 & 0.00 & 3.50 \\ 3.70 & 9.30 & 1.20 & 4.60 & 1.00 \\ 7.40 & 8.30 & 7.60 & 6.10 & 0.50 \\ 5.80 & 4.20 & 7.60 & 2.50 & 3.50 \\ 11.90 & 3.30 & 0.40 & 0.30 & 0.00 \\ 2.90 & 0.00 & 5.00 & 0.00 & 0.00 \\ 4.80 & 0.40 & 1.50 & 2.80 & 1.40\end{array}$

QUFA DOSE ANOVA

Cadmium

FINAL ROOT LENGTH (CM)

DOSE

$\begin{array}{rrrrr}0 & 5 & 10 & 20 & 40 \\ 3.40 & 2.70 & 1.90 & 3.70 & 2.50 \\ 3.90 & 3.80 & 3.00 & 4.80 & 3.20 \\ 4.40 & 4.10 & 3.70 & 1.20 & 3.70 \\ 3.60 & 3.50 & 3.20 & 4.50 & 1.60 \\ 3.90 & 4.40 & 3.80 & 4.60 & 3.50 \\ 4.00 & 3.10 & 4.30 & 3.10 & 2.00 \\ 3.90 & 3.90 & 3.90 & 0.10 & 2.30 \\ 7.30 & 3.40 & 3.50 & 3.50 & 0.50 \\ 3.70 & 3.00 & 3.30 & 2.90 & 1.80 \\ 3.10 & 3.80 & 3.40 & 3.50 & 1.90 \\ 3.10 & 2.50 & 3.20 & 2.00 & 0.50 \\ 4.10 & 0.00 & 3.60 & 0.00 & 0.10 \\ 4.80 & 3.30 & 3.10 & 3.30 & 1.40\end{array}$

Anova: Single-Factor

Summary

$$
\text { Groups }
$$
Count

Sum Average Variance

$\begin{array}{lrrrr}\text { Column 1 } & 13 & 100.3 & 7.7154 & 15.436 \\ \text { Column 2 } & 13 & 56.7 & 4.3615 & 11.573 \\ \text { Column 3 } & 13 & 43 & 3.3077 & 7.8274 \\ \text { Column 4 } & 13 & 40.8 & 3.1385 & 5.5526 \\ \text { Column 5 } & 13 & 20.8 & 1.6 & 4.1417\end{array}$

ANOVA

Source of Variation

\begin{tabular}{ccccccc}
$S S$ & of & NS & $F$ & $P_{\text {-value }}$ & $F$ cri \\
\hline Between Grouf 271.87 & & 4 & 67.968 & 7.6316 & $5 \mathrm{E}-05$ & 2.5252
\end{tabular}

Within Groups

$\begin{array}{lll}60 & 8.9061\end{array}$

Tolal

806.24

64

Anova: Single-Factor

Summary

Groups Count Sum Avarage Variance

$\begin{array}{lrrrr}\text { Column 1 } & 13 & 53.2 & 4.0923 & 1.1541 \\ \text { Column 2 } & 13 & 41.5 & 3.1923 & 1.2181 \\ \text { Column 3 } & 13 & 43.9 & 3.3769 & 0.3286 \\ \text { Column 4 } & 13 & 37.2 & 2.8615 & 2.5459 \\ \text { Column 5 } & 13 & 25 & 1.9231 & 1.2936\end{array}$

ANOVA

Source of Variation

\begin{tabular}{lrrrrrr} 
SS & of & AS & $F$ & P-value & $F$ crit \\
\hline Between Grouf 32.647 & 4 & 8.1618 & 6.2387 & 0.0003 & 2.5252 \\
Within Groups 78.495 & 60 & 1.3083 & & &
\end{tabular}

Within Groups $78.495 \quad 60 \quad 1.3083$

Total

111.14

64 
Table 15 Stem and root elongation responses of mllet to nickel and cadmium dose rates

\begin{tabular}{|c|c|c|c|c|c|c|c|c|c|c|c|}
\hline \multirow{3}{*}{$\begin{array}{l}\text { NI } \\
\text { TOX }\end{array}$} & \multirow{3}{*}{$\begin{array}{c}2 \\
\text { WT } \\
\text { SUAV } \%\end{array}$} & \multirow{3}{*}{$\begin{array}{c}\frac{3}{\text { FINAL }} \\
\text { SuRV } \%\end{array}$} & \multirow{3}{*}{$\begin{array}{l}\text { ROOT } \\
\text { SHAPE } \\
\text { S/Cive }\end{array}$} & & GREEN & \multirow{2}{*}{$\begin{array}{l}\text { 8KOMASS } \\
\text { FINAL ROOT }\end{array}$} & & \multirow{2}{*}{$\begin{array}{l}\text { DFY } \\
\text { FINAL }\end{array}$} & \multirow[b]{2}{*}{ STEM } & \multirow{2}{*}{$\begin{array}{l}\text { BIONASS } \\
\text { FINAL } \\
\end{array}$} & \multirow{3}{*}{$\begin{array}{c}\mathrm{FOOT} \\
5\end{array}$} \\
\hline & & & & \multicolumn{2}{|c|}{ NALSTEM } & & & & & & \\
\hline & & & & $\mathrm{cm}$ & 8 & $\mathrm{~cm}$ & 8 & $\mathrm{~cm}$ & 5 & $\mathrm{~cm}$ & \\
\hline 0 & 100 & 92 & & 7.88 & 3.4783 & 9.22 & 4.7494 & & & & \\
\hline 5 & 77 & 92 & & 4.04 & 3.0626 & 3.47 & 1.8603 & & & & \\
\hline 10 & 77 & 85 & & 5.08 & 3.4966 & 2.27 & 1.1771 & & & & \\
\hline 20 & 36 & 3.1 & & 0.91 & 1.0766 & 0.49 & 0.5204 & & & & \\
\hline 40 & 8 & $B$ & & 0.88 & 1.3266 & 0.60 & 0.6164 & & & & \\
\hline
\end{tabular}

\begin{tabular}{|c|c|c|c|c|c|c|c|c|c|c|c|}
\hline \multirow[t]{2}{*}{$\bar{\infty}$} & 2 & 3 & POOT & & GPEEN & BONASS & & $\mathrm{DPY}$ & & BKOMASS & \multirow{3}{*}{$\begin{array}{c}\text { POOT } \\
s\end{array}$} \\
\hline & \multirow{2}{*}{$\begin{array}{c}\text { INT } \\
\text { SUAV } \%\end{array}$} & \multirow{2}{*}{$\begin{array}{l}\text { FINAL } \\
\text { SURV \% }\end{array}$} & \multirow{2}{*}{$\begin{array}{l}\text { SHAPE } \\
\text { s/c/ve }\end{array}$} & FINAL & SIEM & FINAL & ROOI & FINAL & STEM & FINAL & \\
\hline TOX & & & & $\mathrm{cm}$ & 5 & $\mathrm{~cm}$ & 8 & $\mathrm{~cm}$ & s & $\mathrm{cm}$ & \\
\hline 0 & 100 & 92 & & 7.88 & 3.4783 & 9.22 & 4.7494 & & & & \\
\hline 5 & 92 & 85 & & 5.22 & 2.5719 & 5.90 & 2.5965 & & & & \\
\hline 10 & 77 & 85 & & 4.25 & 2.3497 & 3.79 & 1.9276 & & & & \\
\hline 20 & 85 & 54 & & 1.63 & 1.8794 & 1.41 & 1.7173 & & & & \\
\hline 40 & 8 & 15 & & 0.25 & 0.5502 & 0.06 & 0.171 & & & & \\
\hline
\end{tabular}

PAMI DOSE ANOVA Nickel

\begin{tabular}{rrrrr}
\multicolumn{5}{c}{ FINAL STEM LENGTH(CM) } \\
0 & 5 & 10 & 20 & 40 \\
13.10 & 6.90 & 11.10 & 2.90 & 0.40 \\
6.50 & 9.90 & 1.10 & 0.40 & 0.20 \\
3.20 & 0.60 & 5.20 & 0.20 & 3.50 \\
8.80 & 8.60 & 8.90 & 0.50 & 0.80 \\
9.80 & 2.60 & 0.40 & 0.00 & 0.80 \\
10.40 & 0.00 & 8.10 & 0.00 & 0.30 \\
0.70 & 2.60 & 1.20 & 0.40 & 0.20 \\
7.30 & 2.80 & 0.30 & 1.60 & 0.00 \\
6.60 & 3.70 & 4.90 & 0.30 & 0.70 \\
4.90 & 2.10 & 5.70 & 0.30 & 4.10 \\
9.20 & 4.60 & 4.50 & 2.10 & 0.20 \\
10.60 & 4.10 & 7.20 & 0.20 & 0.00 \\
11.30 & 3.00 & 7.50 & 2.90 & 0.30
\end{tabular}

PAMI DOSE ANOVA Nicke

FINAL ROOT LENGTH (CM)

\begin{tabular}{rrrrr}
\multicolumn{5}{c}{ FNAL ROOTLENGTH(CM) } \\
\multicolumn{5}{c}{ DOSE } \\
& 5 & 10 & 20 & 40 \\
18.00 & 3.40 & 3.60 & 0.80 & 0.30 \\
6.90 & 5.50 & 1.20 & 0.20 & 2.30 \\
3.70 & 1.50 & 2.20 & 0.00 & 0.80 \\
9.80 & 6.20 & 4.00 & 0.00 & 0.60 \\
12.50 & 3.10 & 1.70 & 0.30 & 0.00 \\
7.20 & 0.00 & 2.40 & 0.10 & 0.60 \\
0.00 & 1.00 & 0.90 & 0.00 & 0.00 \\
12.40 & 4.90 & 0.30 & 1.30 & 0.40 \\
7.20 & 3.30 & 1.80 & 0.40 & 1.30 \\
6.90 & 3.50 & 2.40 & 0.20 & 0.40 \\
8.30 & 5.70 & 2.00 & 1.60 & 0.20 \\
13.00 & 2.80 & 4.30 & 0.60 & 0.30 \\
14.00 & 2.80 & 2.70 & 0.90 &
\end{tabular}

Anova: Single-Factor

Summary

Groups Count Sum Awrage Variance

$\begin{array}{llllll}\text { Column 1 } & 13 & 102.4 & 7.8769 & 12.099\end{array}$

Column $2 \quad 13 \quad 52.5 \quad 4.0385 \quad 9.3792$

$\begin{array}{llllll}\text { Column } 3 & 13 & 66.1 & 5.0846 & 12.226\end{array}$

$\begin{array}{lllll}\text { Column } 4 & 13 & 11.8 & 0.9077 & 1.1591\end{array}$

$\begin{array}{llllll}\text { Column } 5 & 13 & 11.5 & 0.8846 & 1.7597\end{array}$

ANOVA

Source of Variation

\begin{tabular}{rrrrrr} 
& SS & df & MS & \multicolumn{1}{c}{$F$} & P-value \\
\hline Between Grour & 457.4 & & 114.35 & 15.612 & $8 \mathrm{E}-09$
\end{tabular}

Within Groups $439.48 \quad 60 \quad 7.3246$

Total $\quad 896.88 \quad 64$

Anova: Single-Factor

Summary

\begin{tabular}{lrrrrr} 
Groups & Count & \multicolumn{1}{c}{ Sum Average Variance } \\
\hline Column 1 & 13 & 119.9 & 9.2231 & 22.557 \\
Column 2 & 13 & 43.7 & 3.3815 & 3.4609 \\
Column 3 & 13 & 29.5 & 2.2692 & 1.3856 \\
Column 4 & 13 & 6.4 & 0.4923 & 0.2708 \\
Column 5 & 13 & 7.8 & 0.6 & 0.38
\end{tabular}

ANOVA

Source of Varlation

\begin{tabular}{lrrrrr} 
& $S S$ & $d f$ & $M S$ & $F$ & P-vaive \\
\hline Between Grouk & 666.39 & 4 & 166.6 & 29.692 & $1 E-13$ \\
Within Groups & 336.65 & 60 & 5.6108 & &
\end{tabular}

Total

$1003 \quad 64$ 

Table 15 (continued)

PAMI DOSE ANOVA

FINAL STEMLENGTH(CM) DOSE

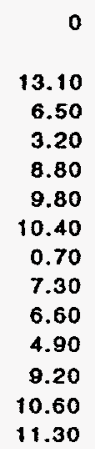

$$
510
$$$$
20
$$

40

0.00

0.00

$\begin{array}{lll}3.10 & 0.00 \quad 1.50\end{array}$

8.20

0.00
6.00

1.50
1.20

$8.20 \quad 3.60 \quad 1.60$

$4.90 \quad 4.20 \quad 1.60$

$\begin{array}{lll}5.60 & 5.90 & 5.60\end{array}$

$\begin{array}{lll}4.80 & 4.50 & 1.90\end{array}$

$\begin{array}{lll}6.50 & 4.60 & 0.20\end{array}$

$\begin{array}{lll}6.30 & 1.60 & 0.30\end{array}$

$\begin{array}{lll}0.20 & 0.30 & 1.20\end{array}$

$\begin{array}{lll}6.80 & 7.00 \quad 0.00\end{array}$

$\begin{array}{lll}7.60 & 7.40 & 0.00\end{array}$

$\begin{array}{lll}4.90 & 4.60 & 0.50\end{array}$

$0.70 \quad 5.50 \quad 5.60$

PAMI DOSE ANOVA

Cadmium

FINAL ROOT LENGTH (CM)

\section{DOSE}

$\begin{array}{rrrrr}0 & 5 & 10 & 20 & 40 \\ 18.00 & 6.30 & 0.60 & 0.50 & 0.00 \\ 6.90 & 8.40 & 5.50 & 0.50 & 0.00 \\ 3.70 & 6.00 & 5.70 & 0.60 & 0.00 \\ 9.80 & 5.10 & 4.60 & 3.30 & 0.00 \\ 12.50 & 6.40 & 4.80 & 5.30 & 0.20 \\ 7.20 & 8.20 & 5.30 & 0.70 & 0.00 \\ 0.00 & 5.70 & 3.30 & 1.20 & 0.00 \\ 12.40 & 8.10 & 0.70 & 0.70 & 0.00 \\ 7.20 & 0.10 & 0.50 & 0.00 & 0.00 \\ 6.90 & 8.00 & 4.20 & 1.10 & 0.60 \\ 8.30 & 6.90 & 5.20 & 0.00 & 0.00 \\ 13.00 & 6.50 & 4.10 & 0.20 & 0.00 \\ 14.00 & 1.00 & 4.80 & 4.20 & \end{array}$

Anova: Slngle-Factor

Summary

\begin{tabular}{lrrrr} 
Groups & Count & \multicolumn{1}{c}{ Sum } & Average & Variance \\
\hline Column 1 & 13 & 102.4 & 7.8769 & 12.099 \\
Column 2 & 13 & 67.8 & 5.2154 & 6.6147 \\
Column 3 & 13 & 55.2 & 4.2462 & 5.521 \\
Column 4 & 13 & 21.2 & 1.6308 & 3.5323 \\
Column 5 & 13 & 3.2 & 0.2462 & 0.3027
\end{tabular}

ANOVA

Source of Varlation

\begin{tabular}{lrrrrr} 
& $S S$ & $d f$ & $M S$ & $F$ & $P$-vatus \\
\hline Between Grouf & 469.95 & 4 & 117.49 & 20.928 & BE-11 \\
Within Groups & 336.83 & 60 & 5.6139 & & \\
Total & Bo6.78 & 64 & & &
\end{tabular}

$\begin{array}{lll}\text { Total } & 806.78 & 64\end{array}$

Anova: Singie-Factor

Summary

Groups Count Sum Average Variance

$\begin{array}{lrrrr}\text { Column 1 } & 13 & 119.9 & 9.2231 & 22.557 \\ \text { Column 2 } & 13 & 76.7 & 5.9 & 6.7417 \\ \text { Column 3 } & 13 & 49.3 & 3.7923 & 3.7158 \\ \text { Column 4 } & 13 & 18.3 & 1.4077 & 2.8491 \\ \text { Column 5 } & 13 & 0.8 & 0.0615 & 0.0292\end{array}$

ANOVA

Source of Variation

\begin{tabular}{rrrrrr} 
& $S S$ & \multicolumn{1}{c}{ df } & $M S$ & $F$ & $P$-value \\
\hline Between Grout 690.76 & 4 & 172.69 & 23.99 & $7 E-12$ \\
Within Groups & 431.91 & 60 & 7.1985 & &
\end{tabular}

Within Groups $431.91 \quad 60 \quad 7.1985$

Total

1122.7

64

$\frac{\text { Forit }}{2.5252}$ 
Table 16 Stem and root elongatton responses of lettuce to nickel and cadium dose rates

\begin{tabular}{|c|c|c|c|c|c|c|c|c|c|c|c|}
\hline \multirow{3}{*}{$\begin{array}{l}\mathrm{NI} \\
\mathrm{TOX}\end{array}$} & \multirow{3}{*}{\begin{tabular}{c|}
2 \\
NT \\
SURV $\%$
\end{tabular}} & \multirow{3}{*}{\begin{tabular}{c|}
3 \\
FINAL \\
SUAV $\%$
\end{tabular}} & \multirow{3}{*}{$\begin{array}{l}\text { AOOT } \\
\text { SHAPE } \\
\text { s/c/vc }\end{array}$} & & GREEN & \multirow{3}{*}{$\begin{array}{l}\text { BIOMASS } \\
\text { FINAL AOOT }\end{array}$} & & \multirow{2}{*}{$\begin{array}{l}\text { DFY } \\
\text { FINAL }\end{array}$} & \multirow[b]{2}{*}{ STEM } & \multirow{2}{*}{$\begin{array}{l}\text { BIONASS } \\
\text { FINAL }\end{array}$} & \multirow{3}{*}{$\begin{array}{c}\text { ROOT } \\
s\end{array}$} \\
\hline & & & & \multicolumn{2}{|c|}{ FINAL STEM } & & & & & & \\
\hline & & & & $\mathrm{cm}$ & $\mathbf{s}$ & & $\mathbf{s}$ & $\mathrm{cm}$ & s & $\mathrm{cm}$ & \\
\hline 0 & 31 & 31 & & 0.28 & 0.5019 & 1.09 & 2.6043 & & & & \\
\hline 5 & 15 & 38 & & 0.53 & 0.7443 & 0.16 & 0.2329 & & & & \\
\hline 10 & 23 & 15 & & 0.48 & 0.6918 & 0.45 & 0.6765 & & & & \\
\hline 20 & 31 & 46 & & 0.99 & 0.8301 & 0.34 & 0.2293 & & & & \\
\hline 40 & 23 & 15 & & 0.51 & 0.8261 & 0.18 & 0.3113 & & & & \\
\hline
\end{tabular}

\begin{tabular}{|c|c|c|c|c|c|c|c|c|c|c|c|}
\hline \multirow{3}{*}{$\begin{array}{l}\infty \\
\text { Tox }\end{array}$} & 2 & 3 & AOOT & & GFEN & BKOMASS & & DRY & & BKOMASS & \multirow{3}{*}{$\begin{array}{c}\text { POOT } \\
\text { s }\end{array}$} \\
\hline & \multirow{2}{*}{$\begin{array}{c}\text { NNT } \\
\text { SURV \% } \\
\end{array}$} & \multirow{2}{*}{$\begin{array}{l}\text { FINAL } \\
\text { SURY\% }\end{array}$} & \multirow{2}{*}{$\begin{array}{l}\text { SHAPE } \\
\text { S/C/YC }\end{array}$} & FINAL & STEM & FINAL & FOOT & FINAL & STEM & FINAL & \\
\hline & & & & $\mathrm{cm}$ & $s$ & $\mathrm{~cm}$ & $s$ & $\mathrm{~cm}$ & $s$ & $\mathrm{~cm}$ & \\
\hline 0 & 31 & 31 & & 0.28 & 0.5019 & 1.09 & 2.6043 & & & & \\
\hline 5 & 8 & 23 & & 0.22 & 0.3539 & 0.18 & 0.5786 & & & & \\
\hline 10 & 23 & 8 & & 0.22 & 0.3976 & 0.09 & 0.1706 & & & & \\
\hline 20 & 8 & 8 & & 0.42 & 0.6821 & 0.19 & 0.3639 & & & & \\
\hline 40 & 8 & 15 & & 0.50 & 0.4983 & 0.27 & 0.2869 & & & & \\
\hline
\end{tabular}

LASA DOSE ANOVA Nickel

FINAL STEMLENGTH (CM) DOSE

0$$
5
$$

40

$\begin{array}{lllll}0.00 & 0.00 & 1.50 & 0.00 & 1.30 \\ 0.90 & 0.00 & 0.00 & 1.60 & 0.00\end{array}$

$\begin{array}{lllll}0.00 & 1.10 & 0.00 & 1.60 & 1.20\end{array}$

$\begin{array}{lllll}0.00 & 1.90 & 1.50 & 0.00 & 0.00\end{array}$

$\begin{array}{lllll}0.00 & 0.00 & 0.00 & 0.60 & 0.00\end{array}$

$\begin{array}{lllll}0.00 & 0.00 & 0.50 & 0.00 & 0.00\end{array}$

$\begin{array}{lllll}0.00 & 0.00 & 0.00 & 1.50 & 0.00\end{array}$

$\begin{array}{lllll}0.70 & 0.00 & 0.00 & 1.00 & 0.00\end{array}$

$\begin{array}{lllll}1.60 & 1.70 & 0.00 & 1.70 & 0.00\end{array}$

$\begin{array}{lllll}0.00 & 0.00 & 0.50 & 1.30 & 0.00\end{array}$

$\begin{array}{lllll}0.40 & 0.80 & 0.00 & 1.00 & 2.10\end{array}$

$\begin{array}{lllll}0.00 & 1.40 & 1.80 & 2.60 & 2.00\end{array}$

$\begin{array}{lllll}0.00 & 0.00 & 0.30 & 0.00 & 0.00\end{array}$

LASA DOSE ANOVA Nickel

FINAL ROOT LENGTH (CM) DOSE$$
0
$$$$
5
$$$$
10
$$$$
20
$$

0.00

9.20
0.00

0.00
0.00

0.00

0.00

0.00

2.80

2.10

0.00

0.10

0.00

0.00

$\begin{array}{llll}0.00 & 0.30 & 0.00 & 0.40 \\ 2.00 & 0.00 & 0.60 & 0.00 \\ 0.50 & 0.00 & 0.50 & 0.50 \\ 0.50 & 0.50 & 0.50 & 0.00 \\ 0.00 & 0.00 & 0.20 & 0.00 \\ 0.00 & 0.30 & 0.00 & 0.00 \\ 0.00 & 0.00 & 0.40 & 0.00 \\ 0.00 & 0.00 & 0.60 & 0.00 \\ 0.60 & 1.80 & 0.50 & 0.00 \\ 0.00 & 0.40 & 0.50 & 0.00 \\ 0.30 & 0.00 & 0.40 & 0.40 \\ 0.20 & 0.50 & 0.20 & 1.00 \\ 0.00 & 2.00 & 0.00 & 0.00\end{array}$

Anova: Single-Factor

Summary

Groups Count Sum Average Variance

$\begin{array}{llllll}\text { Column } 1 & 13 & 3.6 & 0.2769 & 0.2519\end{array}$

$\begin{array}{lllll}\text { Column } 2 & 13 & 6.9 & 0.5308 & 0.554\end{array}$

$\begin{array}{llllll}\text { Column } 3 & 13 & 6.2 & 0.4769 & 0.4786\end{array}$

$\begin{array}{lllll}\text { Column } 4 & 13 & 12.9 & 0.9923 & 0.6891\end{array}$

$\begin{array}{llllll}\text { Column } 5 & 13 & 6.6 & 0.5077 & 0.6824\end{array}$

ANOVA

Source of Variation

\begin{tabular}{ccccccc} 
SS & $d f$ & $M S$ & $F$ & $P_{\text {-value }}$ & $F$ crin \\
\hline Between Grouf 3.6071 & 4 & 0.9018 & 1.6976 & 0.1624 & 2.5252
\end{tabular}

WIthin Groups

$\begin{array}{ll}60 & 0.5312\end{array}$

Total

35.479

64

Anova: Single-Factor

Summary

Groups Count Sum Avgrage Vaniance

$\begin{array}{lllll}\text { Column } 1 & 13 & 14.2 & 1.0923 & 6.7824\end{array}$

$\begin{array}{llllll}\text { Column 2 } & 13 & 4.1 & 0.3154 & 0.3081\end{array}$

$\begin{array}{lllll}\text { Column } 3 & 13 & 5.8 & 0.4462 & 0.4577\end{array}$

$\begin{array}{llllll}\text { Column } 4 & 13 & 4.4 & 0.3385 & 0.0526\end{array}$

$\begin{array}{llllll}\text { Column } 5 & 13 & 2.3 & 0.1769 & 0.0969\end{array}$

ANOVA

Source of Varlation

\begin{tabular}{ccccccc} 
SS & $d f$ & MS & $F$ & $P_{\text {-value }}$ & $F$ cri \\
\hline Between Grout 6.6932 & & 4 & 1.6733 & 1.0869 & 0.3712 & 2.5252
\end{tabular}

Within Groups $92.372 \quad 60 \quad 1.5395$

Total $\quad 99.066 \quad 64$ 
Table 16 (continued)

LASA DOSE ANOVA

Cadmium

FINAL STEMLENGTH (CM) DOSE

$\begin{array}{rrrrr}0 & 5 & 10 & 20 & 40 \\ 0.00 & 0.00 & 0.00 & 0.00 & 0.00 \\ 0.90 & 0.00 & 0.00 & 1.40 & 0.00 \\ 0.00 & 0.00 & 0.00 & 0.00 & 0.00 \\ 0.00 & 0.00 & 0.90 & 0.00 & 1.10 \\ 0.00 & 0.90 & 0.40 & 0.00 & 0.30 \\ 0.00 & 0.70 & 0.30 & 0.90 & 0.80 \\ 0.00 & 0.00 & 0.00 & 0.00 & 1.20 \\ 0.70 & 0.60 & 0.00 & 1.50 & 1.30 \\ 1.60 & 0.00 & 0.00 & 0.00 & 0.80 \\ 0.00 & 0.00 & 0.00 & 0.00 & 0.00 \\ 0.40 & 0.00 & 0.00 & 1.70 & 0.60 \\ 0.00 & 0.70 & 0.00 & 0.00 & 0.00 \\ 0.00 & 0.00 & 1.20 & 0.00 & 0.40\end{array}$

LASA DOSE ANOVA

Cadmium

FNAL AOOT LENGTH (CM)

$$
\text { DOSE }
$$

$\begin{array}{rrrrr}0 & 5 & 10 & 20 & 40 \\ 0.00 & 0.00 & 0.00 & 0.00 & 0.00 \\ 9.20 & 0.00 & 0.00 & 0.30 & 0.00 \\ 0.00 & 0.00 & 0.00 & 0.00 & 0.70 \\ 0.00 & 0.00 & 0.20 & 0.00 & 0.20 \\ 0.00 & 0.00 & 0.40 & 0.00 & 0.40 \\ 0.00 & 0.10 & 0.10 & 0.30 & 0.30 \\ 0.00 & 0.00 & 0.00 & 0.00 & 0.20 \\ 2.80 & 2.10 & 0.00 & 0.40 & 0.50 \\ 2.10 & 0.00 & 0.00 & 0.00 & 0.20 \\ 0.00 & 0.00 & 0.00 & 0.00 & 0.00 \\ 0.10 & 0.00 & 0.00 & 0.20 & 0.90 \\ 0.00 & 0.20 & 0.00 & 0.00 & 0.00 \\ 0.00 & 0.00 & 0.50 & 1.30 & 0.10\end{array}$

Anova: Single-Factor

Summary

Groups Count Sum Average Variance

$\begin{array}{lrrrr}\text { Column 1 } & 13 & 3.6 & 0.2769 & 0.2518 \\ \text { Column 2 } & 13 & 2.9 & 0.2231 & 0.1253 \\ \text { Column 3 } & 13 & 2.8 & 0.2154 & 0.1581 \\ \text { Column 4 } & 13 & 5.5 & 0.4231 & 0.4653 \\ \text { Column 5 } & 13 & 6.5 & 0.5 & 0.2483\end{array}$

ANOVA

Source of Varlation

\begin{tabular}{cccccccc} 
& SS & $d l$ & NS & $F$ & P-value & $F$ cri \\
\hline Between Grouf & 0.844 & 4 & 0.211 & 0.8448 & 0.5024 & 2.5252
\end{tabular}

Within Groups $14.986 \quad 60 \quad 0.2498$

Total

$15.83 \quad 64$

Anova: Single-Factor

Summary

Groups Count Sum Average Variance

$\begin{array}{lllll}\text { Column } 1 & \text { 13 } & 14.2 & 1.0923 & 6.7824\end{array}$

$\begin{array}{llllll}\text { Column 2 } & 13 & 2.4 & 0.1846 & 0.3347\end{array}$

$\begin{array}{llllll}\text { Column } 3 & 13 & 1.2 & 0.0923 & 0.0291\end{array}$

$\begin{array}{lllll}\text { Column } 4 & 13 & 2.5 & 0.1923 & 0.1324\end{array}$

$\begin{array}{llllll}\text { Column } 5 & 13 & 3.5 & 0.2692 & 0.0823\end{array}$

ANOVA

Source of Variatlon

\begin{tabular}{lrrrrrr} 
& $S S$ & $d f$ & MS & $F$ & P-vatue & F crit \\
\hline Between Grouk & 8.7732 & 4 & 2.1933 & 1.4898 & 0.2166 & 2.5252 \\
Within Groups & 88.332 & 60 & 1.4722 & & & \\
& & & & & & \\
Total & 97.106 & 64 & & &
\end{tabular}


Table 17. Stem and root elongation responses of green ash to nickel and cadmium dose rates

\begin{tabular}{|c|c|c|c|c|c|c|c|c|c|c|c|c|}
\hline \multirow{3}{*}{$\begin{array}{l}\text { N } \\
\text { TOX }\end{array}$} & 2 & 3 & ROOT & GFEEN & & BKanass & & DFY & & BOMASS & \multirow{3}{*}{\multicolumn{2}{|c|}{$\begin{array}{l}\text { TIWET. ค.O. BOX } 709 \\
\text { \& }(803) 646-2200\end{array}$}} \\
\hline & \multirow{2}{*}{$\begin{array}{l}\text { INT } \\
\text { SUAV } \\
\end{array}$} & FINAL & \multirow{2}{*}{$\begin{array}{l}\text { SHAPE } \\
\text { s/c/vc }\end{array}$} & FINAL ST & & \multicolumn{2}{|l|}{ FINAL AOOT } & FINAL & & FINAL & & \\
\hline & & SURV \% & & $\mathrm{cm}$ & $\mathbf{s}$ & AOOT cm & $s$ & STEM cm & $\mathbf{s}$ & POOT cm & & \\
\hline 0 & 77 & 31 & & 1.31 & 0.7932 & 1.22 & 1.644104 & & & & & \\
\hline 5 & 62 & 30 & & 1.33 & 0.6824 & 1.26 & 1.636836 & & & & & \\
\hline 10 & 92 & 30 & & 1.63 & 0.8626 & 0.85 & 0.545612 & & & & & \\
\hline 20 & 69 & 31 & & 1.66 & 0.565 & 0.85 & 0.545612 & & & & & \\
\hline 40 & 85 & 23 & & 1.41 & $0.540 B$ & 0.82 & 0.559533 & & & & & \\
\hline
\end{tabular}

\begin{tabular}{|c|c|c|c|c|c|c|c|c|c|c|}
\hline \multirow{3}{*}{$\begin{array}{l}\text { CD } \\
\text { TOX }\end{array}$} & 2 & 3 & मOOT & \multicolumn{2}{|c|}{ GPEEN } & BOMASS & & ORY & BOMASS & \multirow[b]{3}{*}{8} \\
\hline & NT & FINAL & SHAPE & FINAL ST & & FINAL & & FINAL & FINAL & \\
\hline & URV & SURV \% & s/c/ve & $\mathrm{cm}$ & 8 & POOT & & STEM & POOT & \\
\hline 0 & 77 & 31 & & 1.31 & 0.7932 & 1.22 & 1.644104 & & & \\
\hline 5 & 69 & 38 & & 1.31 & 0.6344 & 1.12 & 1.195833 & & & \\
\hline 10 & 77 & 46 & & 1.44 & 0.7066 & 1.08 & 0.991502 & & & \\
\hline 20 & 23 & 54 & & 1.18 & 0.5257 & 0.95 & 0.595281 & & & \\
\hline 40 & 69 & 23 & & 1.17 & 0.5851 & 0.72 & 0.435596 & & & \\
\hline
\end{tabular}

FRPE DOSE ANOVA

Nickel

FINAL STEMLENGTH (CM)

$\begin{array}{ccccc}0 & 5 & 10 & 20 & 40 \\ 1.40 & 0.00 & 0.50 & 1.90 & 1.30 \\ 2.50 & 1.10 & 2.40 & 1.80 & 0.30 \\ 0.00 & 1.20 & 0.00 & 1.30 & 0.90 \\ 0.60 & 1.60 & 0.80 & 1.80 & 0.80 \\ 1.60 & 1.30 & 2.30 & 2.00 & 0.90 \\ 1.80 & 1.80 & 1.40 & 0.50 & 1.70 \\ 0.80 & 0.20 & 2.10 & 2.20 & 1.90 \\ 1.40 & 0.00 & 1.30 & 1.90 & 2.10 \\ 1.20 & 1.40 & 1.50 & 0.70 & 1.70 \\ 2.50 & 1.90 & 3.30 & 1.20 & 1.80 \\ 1.60 & 2.40 & 2.30 & 2.10 & 1.70 \\ 0.00 & 1.20 & 1.50 & 2.30 & 1.30 \\ 1.60 & 1.80 & 1.80 & 1.90 & 1.90\end{array}$

FAPE DOSE ANOVA

Nicke!

FINAL ROOT LENGTH (CM)

$\begin{array}{llll}0 & 5 & 10 & 20 \\ 0.70 & 1.30 & 0.30 & 0.00 \\ 6.40 & 1.00 & 0.40 & 0.30 \\ 0.20 & 0.20 & 1.50 & 0.70 \\ 0.80 & 0.40 & 0.00 & 1.00 \\ 1.50 & 2.10 & 0.70 & 0.60 \\ 2.00 & 0.80 & 0.90 & 0.90 \\ 0.00 & 0.00 & 0.70 & 1.80 \\ 1.00 & 0.60 & 0.30 & 0.70 \\ 0.40 & 0.20 & 0.70 & 0.30 \\ 1.00 & 0.40 & 0.90 & 0.20 \\ 0.60 & 0.70 & 0.70 & 0.90 \\ 0.50 & 0.40 & 0.50 & 0.20 \\ 0.70 & 0.10 & 0.50 & 0.40\end{array}$

Anova: Single-Factor

Summary

\begin{tabular}{|c|c|c|c|c|}
\hline Groups & Count & Sum & Averago & Variance \\
\hline Column 1 & 13 & 17 & 1.30769231 & 0.629103 \\
\hline Column 2 & 13 & 15.9 & 1.22307692 & 0.561923 \\
\hline Column 3 & 13 & 21.2 & 1.63076923 & 0.778974 \\
\hline Column 4 & 13 & 21.6 & 1.66153646 & 0.319231 \\
\hline Column 5 & 13 & 18.3 & 1.40769231 & 0.292436 \\
\hline
\end{tabular}

ANOVA

TWET, P.O. Box 709

Source of Variation

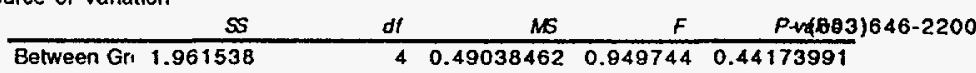

$\begin{array}{llll}\text { Within Grou } \quad 30.98 & 60 & 0.51633333\end{array}$

Total $\quad 32.94154 \quad 64$

F crit 2.525212

Anova: Single-Factor

Summary

\begin{tabular}{rrrrr} 
Groups & Count & Sum & Average & Variance \\
\hline Column 1 & 13 & 15.8 & 1.21538462 & 2.703077 \\
Column 2 & 13 & 8.2 & 0.63076923 & 0.332308 \\
Column 3 & 13 & 8.1 & 0.62307692 & 0.135256 \\
Column 4 & 13 & 8 & 0.61538462 & 0.224744 \\
Column 5 & 13 & 8.2 & 0.63076923 & 0.223974
\end{tabular}

ANOVA

Source of Varlation

\begin{tabular}{rrrrrr} 
& SS & df & MS & $F$ & P-value \\
\hline Between Gri & 3.627077 & 4 & 0.90676923 & 1.252666 & 0.29862135 \\
Within Grau & 43.43231 & 60 & 0.72387179 & &
\end{tabular}

Total

47.05938

64

F crit 
FRPE DOSE ANOVA

Cadmium

FINAL STEM LENGTH (CM) DOSE

$\begin{array}{lllll}0 & 5 & 10 & 20 & 40 \\ 1.40 & 0.50 & 1.10 & 0.80 & 1.60 \\ 2.50 & 1.10 & 1.50 & 0.70 & 2.20 \\ 0.00 & 1.20 & 1.50 & 1.90 & 1.70 \\ 0.60 & 1.80 & 2.50 & 1.30 & 1.10 \\ 1.60 & 2.00 & 1.10 & 1.90 & 0.00 \\ 1.80 & 1.80 & 0.70 & 0.60 & 1.00 \\ 0.80 & 2.30 & 0.70 & 0.90 & 1.00 \\ 1.40 & 1.80 & 1.20 & 1.70 & 1.20 \\ 1.20 & 1.20 & 1.20 & 0.80 & 1.10 \\ 2.50 & 0.30 & 2.70 & 1.70 & 1.80 \\ 1.60 & 0.90 & 0.60 & 0.40 & 0.40 \\ 0.00 & 0.50 & 2.50 & 1.60 & 1.30 \\ 1.60 & 1.60 & 1.40 & 1.10 & 0.80\end{array}$

FRPE DOSE ANOVA

Cadmium

FINAL ROOTLENGTH (CM)

$\begin{array}{ccccc}0 & 5 & \begin{array}{c}\text { DOSE } \\ 10\end{array} & 20 & 40 \\ 0.70 & 0.20 & 0.70 & 1.10 & 0.80 \\ 6.40 & 0.60 & 0.50 & 1.50 & 0.60 \\ 0.20 & 1.10 & 0.50 & 0.30 & 0.80 \\ 0.80 & 1.90 & 2.70 & 1.90 & 1.40 \\ 1.50 & 4.40 & .1 .50 & 0.60 & 0.20 \\ 2.00 & 0.60 & 0.30 & 0.40 & 0.30 \\ 0.00 & 2.30 & 0.10 & 0.80 & 0.90 \\ 1.00 & 0.00 & 0.80 & 1.90 & 1.00 \\ 0.40 & 0.50 & 1.40 & 0.40 & 0.20 \\ 1.00 & 0.00 & 3.50 & 0.60 & 0.90 \\ 0.60 & 0.80 & 0.50 & 0.50 & 0.50 \\ 0.50 & 1.00 & 1.00 & 1.70 & 1.50 \\ 0.70 & 1.20 & 0.60 & 0.70 & 0.20\end{array}$

Anova: Single-Factor
Summary

\begin{tabular}{lrrrrr} 
Groups & Count & Sum & Average & Variance \\
\hline Column 1 & 13 & 17 & 1.30769231 & 0.629103 \\
Column 2 & 13 & 17 & 1.30769231 & 0.402436 \\
Column 3 & 13 & 18.7 & 1.43846154 & 0.499231 \\
Column 4 & 13 & $15: 4$ & 1.18461538 & 0.27641 \\
Column 5 & 13 & 15.2 & 1.16923077 & 0.342308 \\
& & & &
\end{tabular}

TWET, P.O. Box 709

(803)646-2200
Source of Variation

\begin{tabular}{lrrrrr} 
& $S S$ & $d f$ & $M S$ & $F$ & P-value \\
\hline Between Grd & 0.624 & 4 & 0.156 & 0.362877 & 0.83407361 \\
Within Grou & 25.79385 & 60 & 0.42989744 & & \\
Total & 26.41785 & 64 & & &
\end{tabular}

$\frac{F \text { crit }}{2.525212}$

Anova: Single-Factor

Summary

\begin{tabular}{crrrrr} 
Groups & Count & Sum & Average & Variance \\
\hline Column 1 & 13 & 15.8 & 1.21538462 & 2.703077 \\
Column 2 & 13 & 14.6 & 1.12307692 & 1.430256 \\
Column 3 & 13 & 14.1 & 1.08461538 & 0.983077 \\
Column 4 & 13 & 12.4 & 0.95384615 & 0.354359 \\
Column 5 & 13 & 9.3 & 0.71538462 & 0.189744
\end{tabular}

ANOVA

TWET, P.O. Box 709

Source of Variation

\begin{tabular}{c} 
SS \\
\hline Between Gri 1.951692
\end{tabular}

$\begin{array}{llll}\text { df } & \text { MS } & F & \text { P-va683)646-2200 }\end{array}$ Within Grou 67.92615 $\begin{array}{llll}0.48792308 & 0.430988 & 0.78568365\end{array}$

$\begin{array}{lll}\text { Total } & 69.87785 & 64\end{array}$ 
Figure 1.

Impact of cadmium on germination of Liquidambar styraciflua

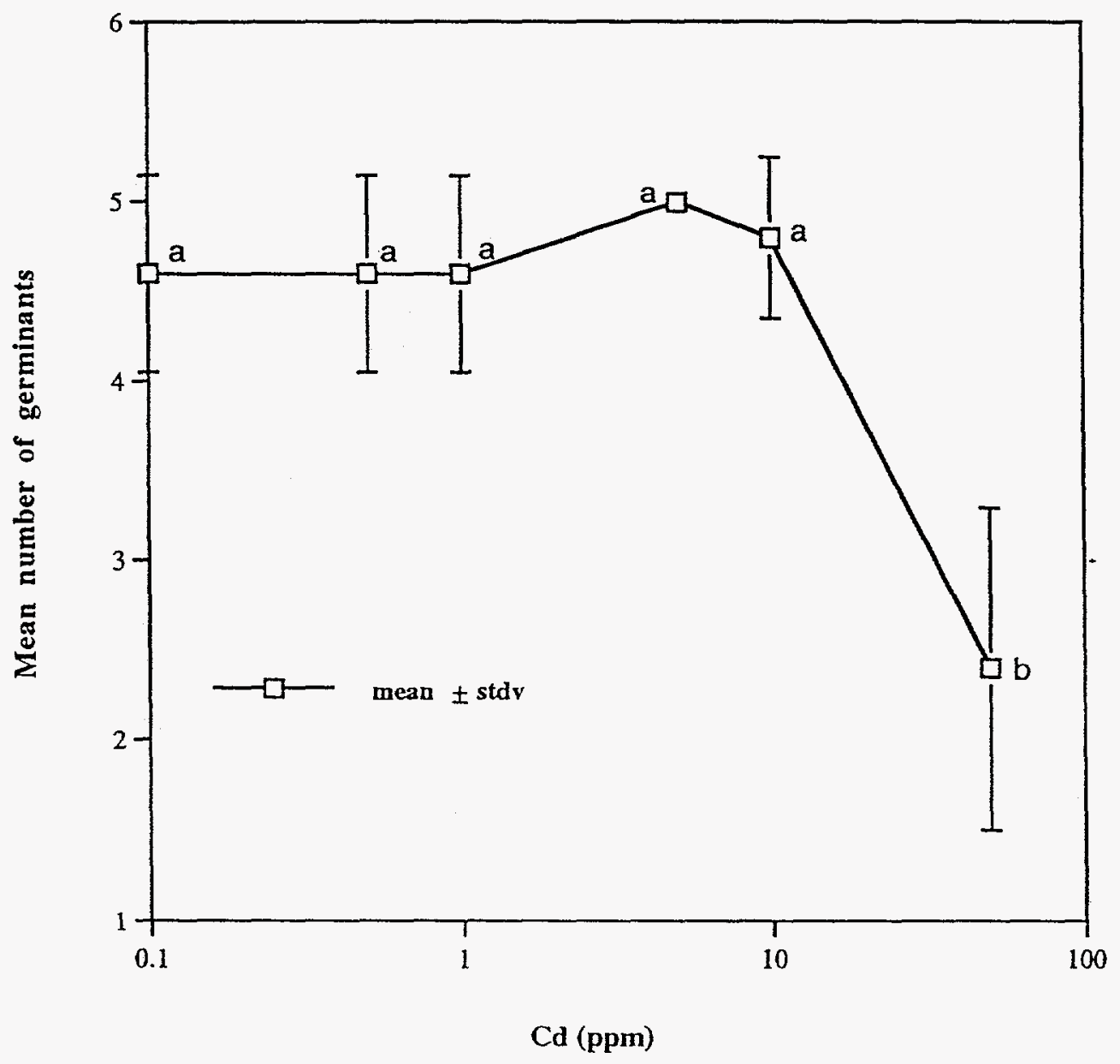


Figure 2.

Impact of nickel on germination of Liquidambar styraciflua

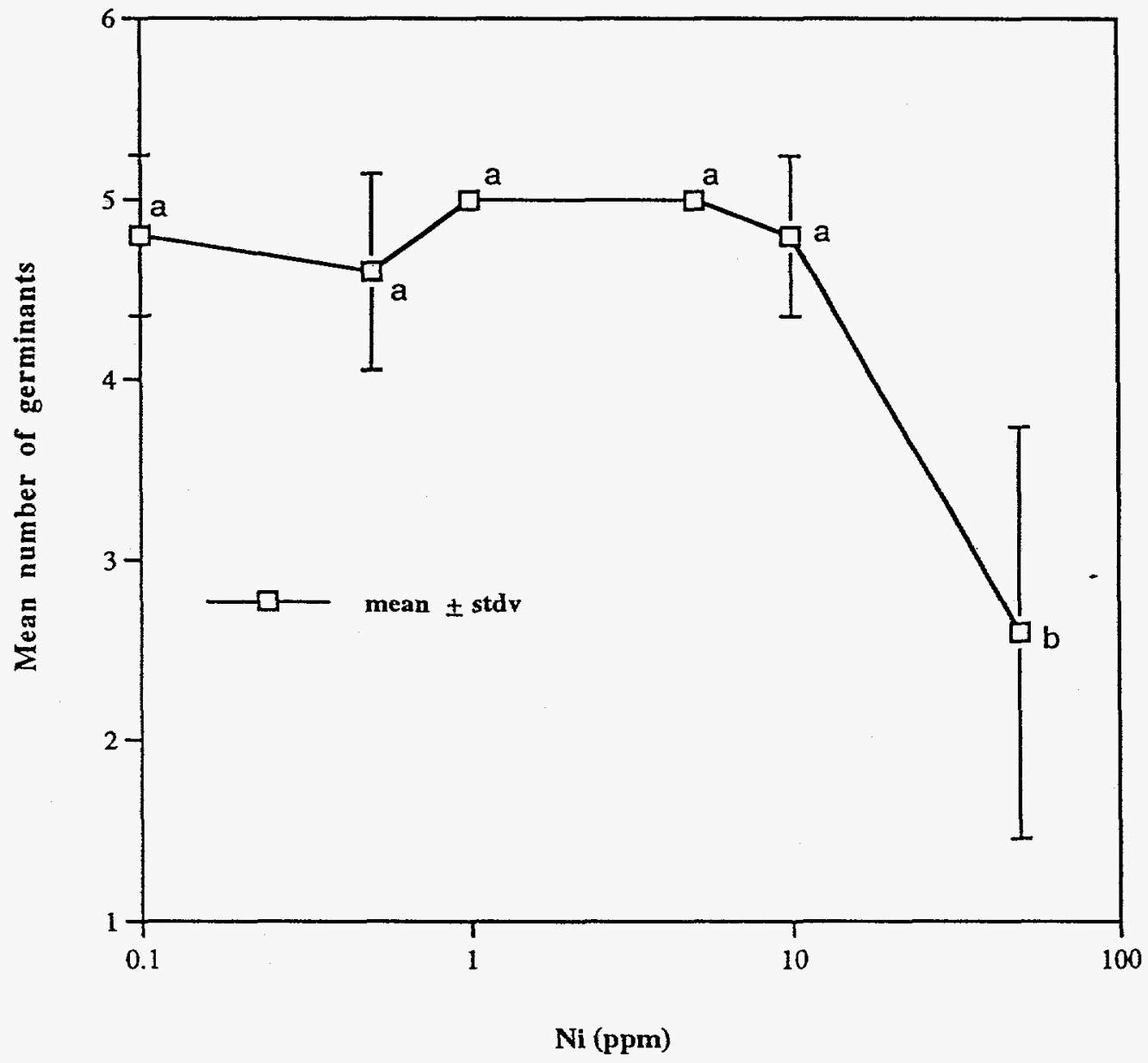


Figure 3 .

Impact of anthracene on germination of Liquidambar styraciflua

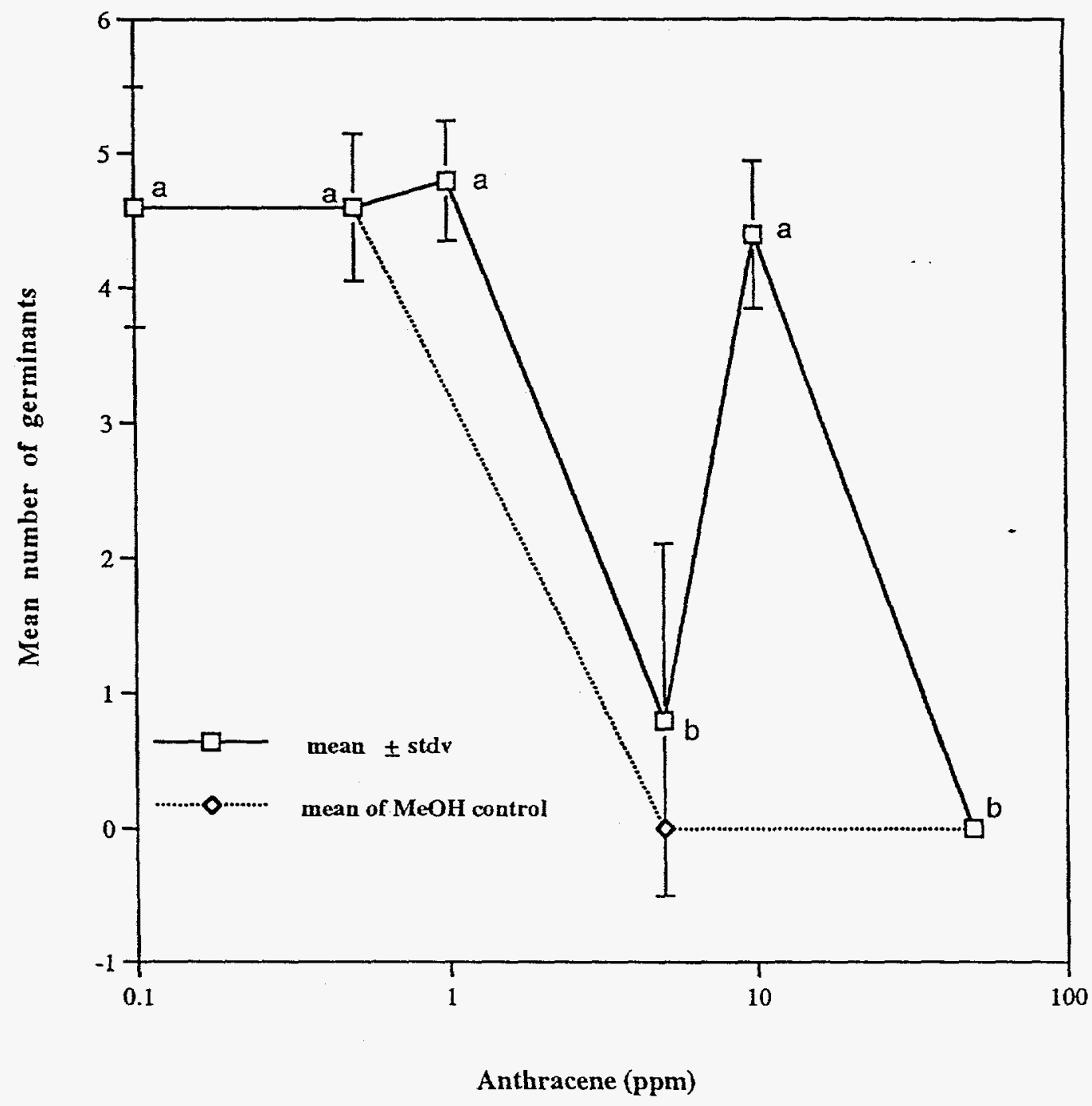


Figure 4.

Impact of atrazine on germination of Liquidambar styraciflua

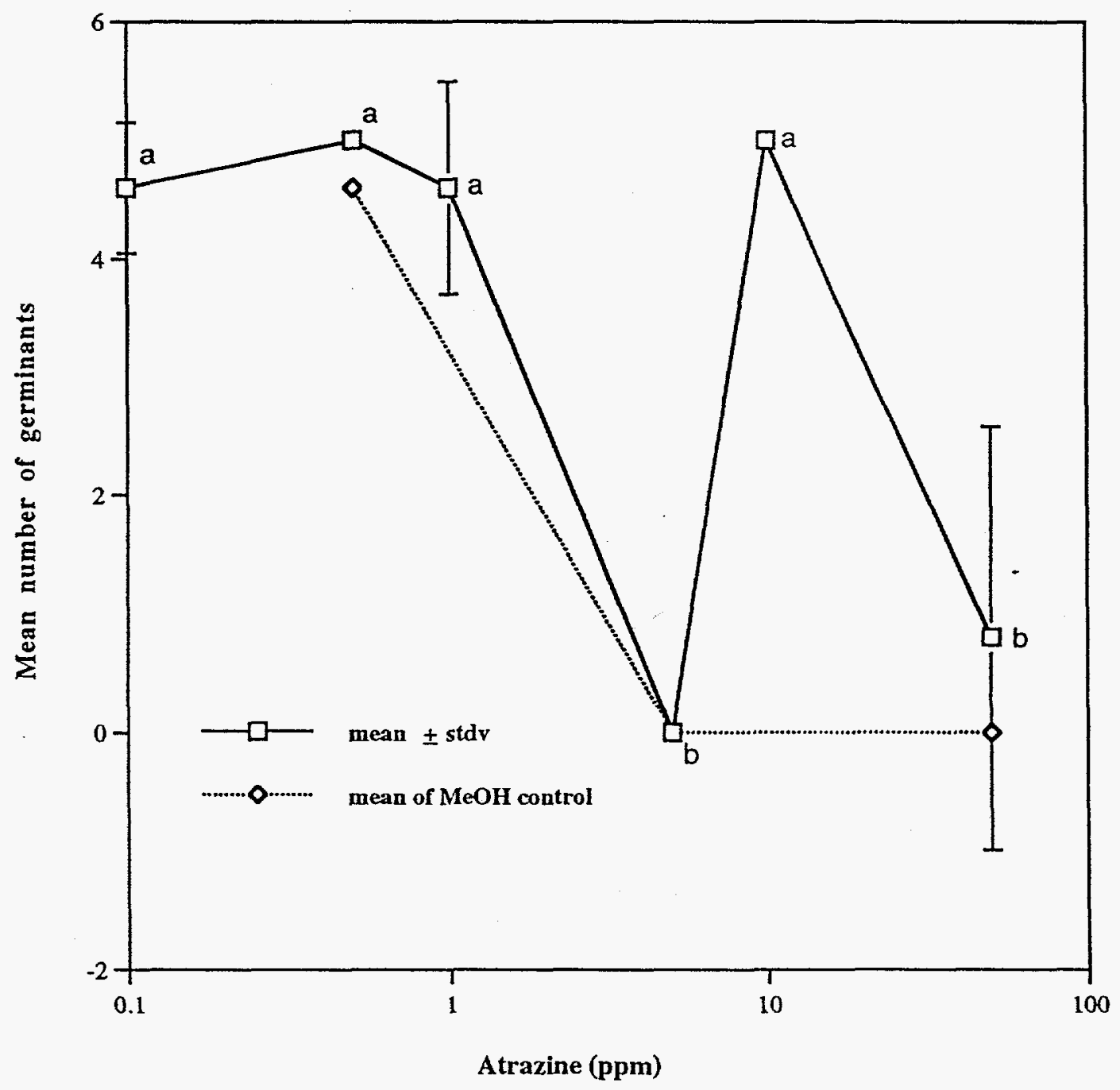


Figure 5.

Impact of pce on germination of Liquidambar styraciflua

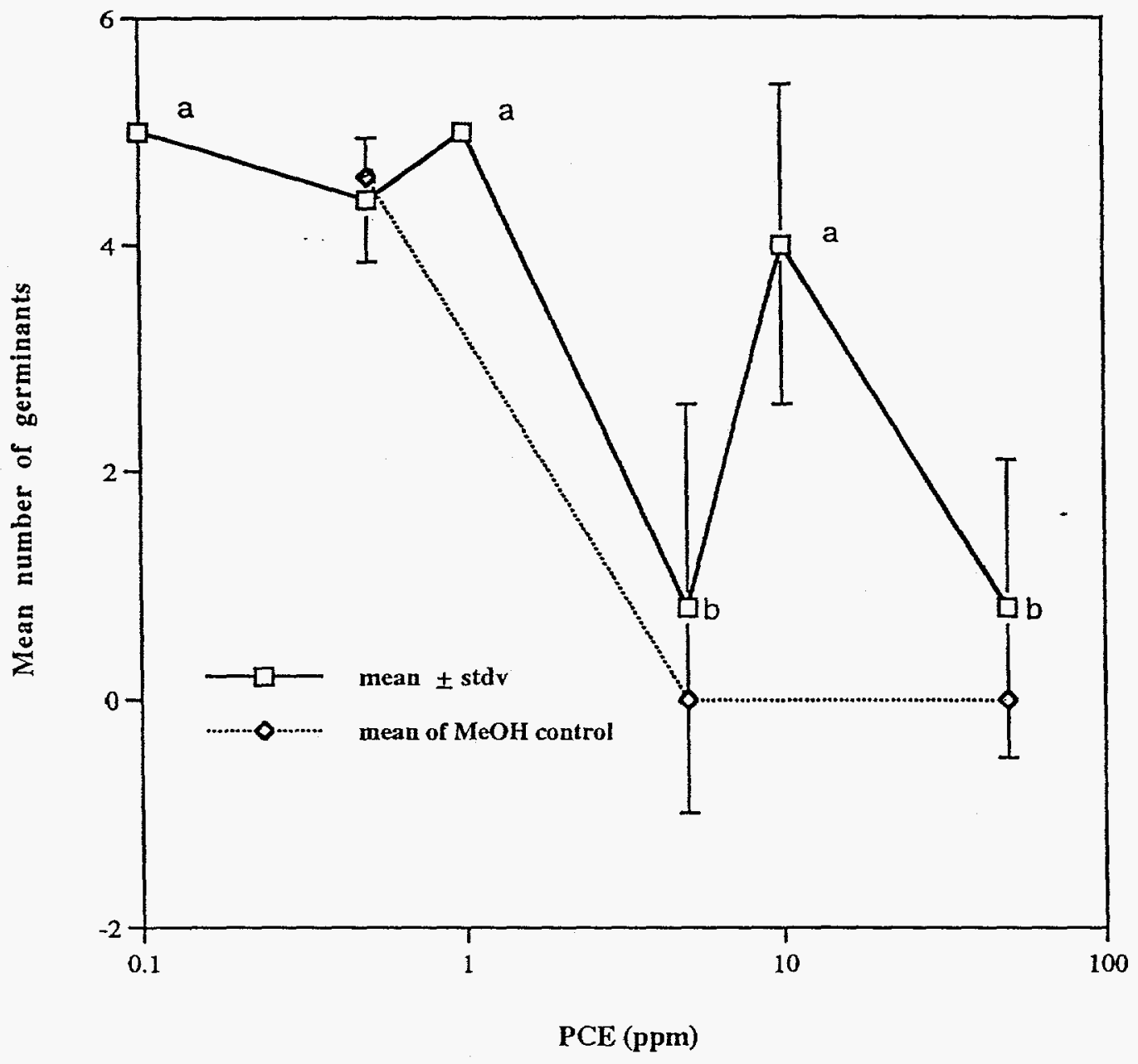


Figure 6.

Impact of cadmium on germination of Panicum miliaceum

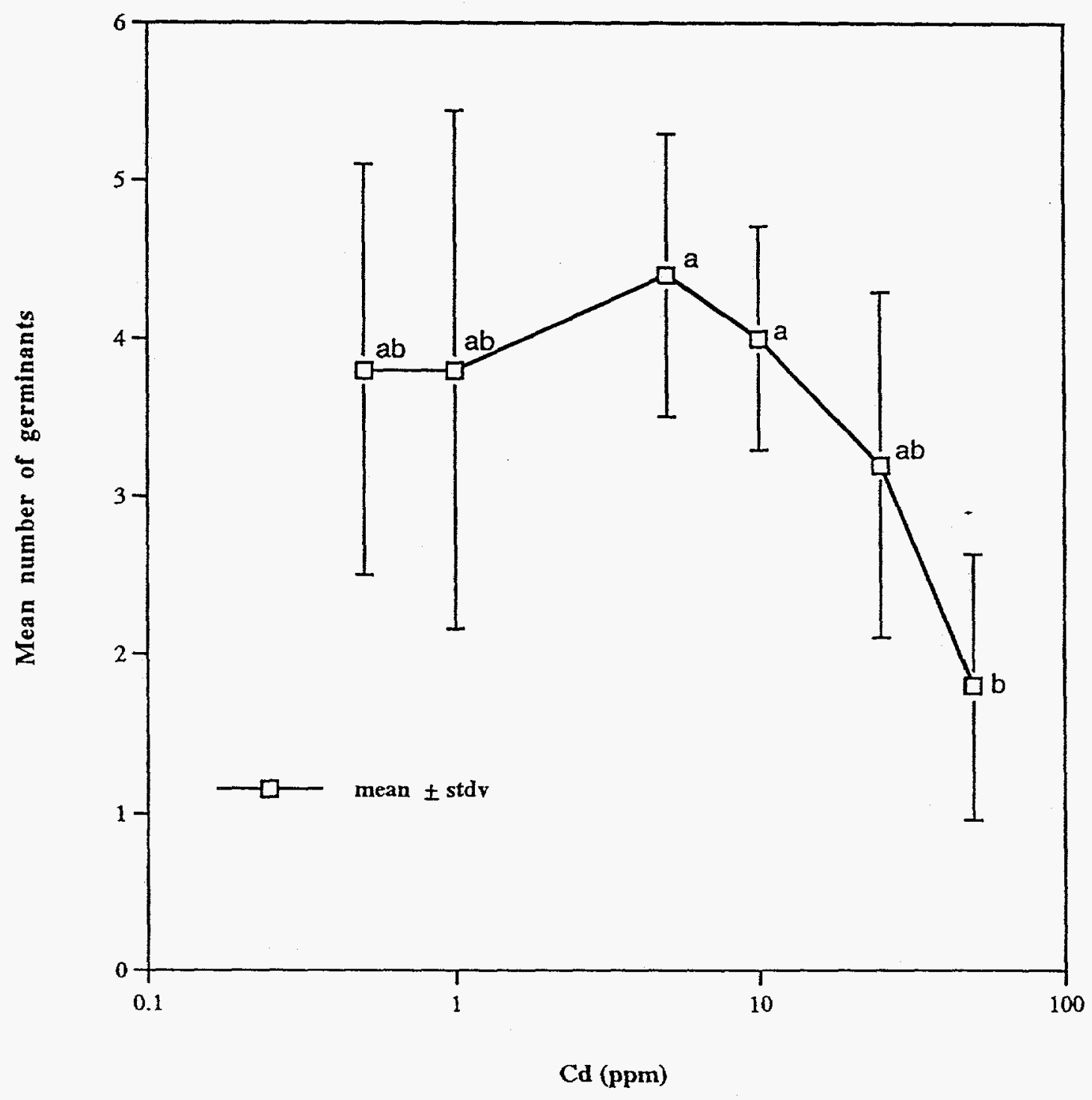


Figure 7.

Impact of nickel on germination of Panicum miliaceum

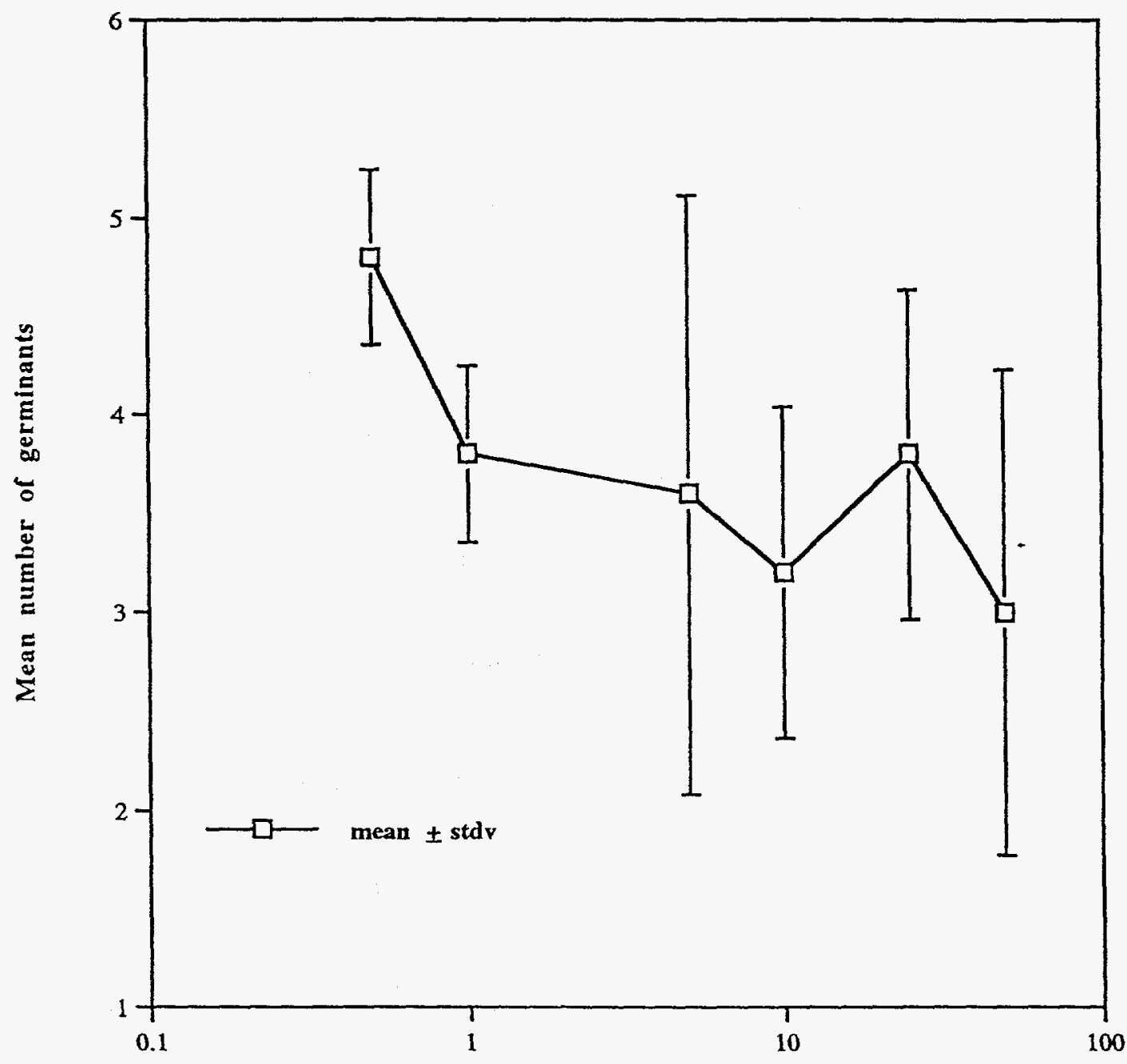

$\mathrm{Ni}(\mathrm{ppm})$ 
Figure 8.

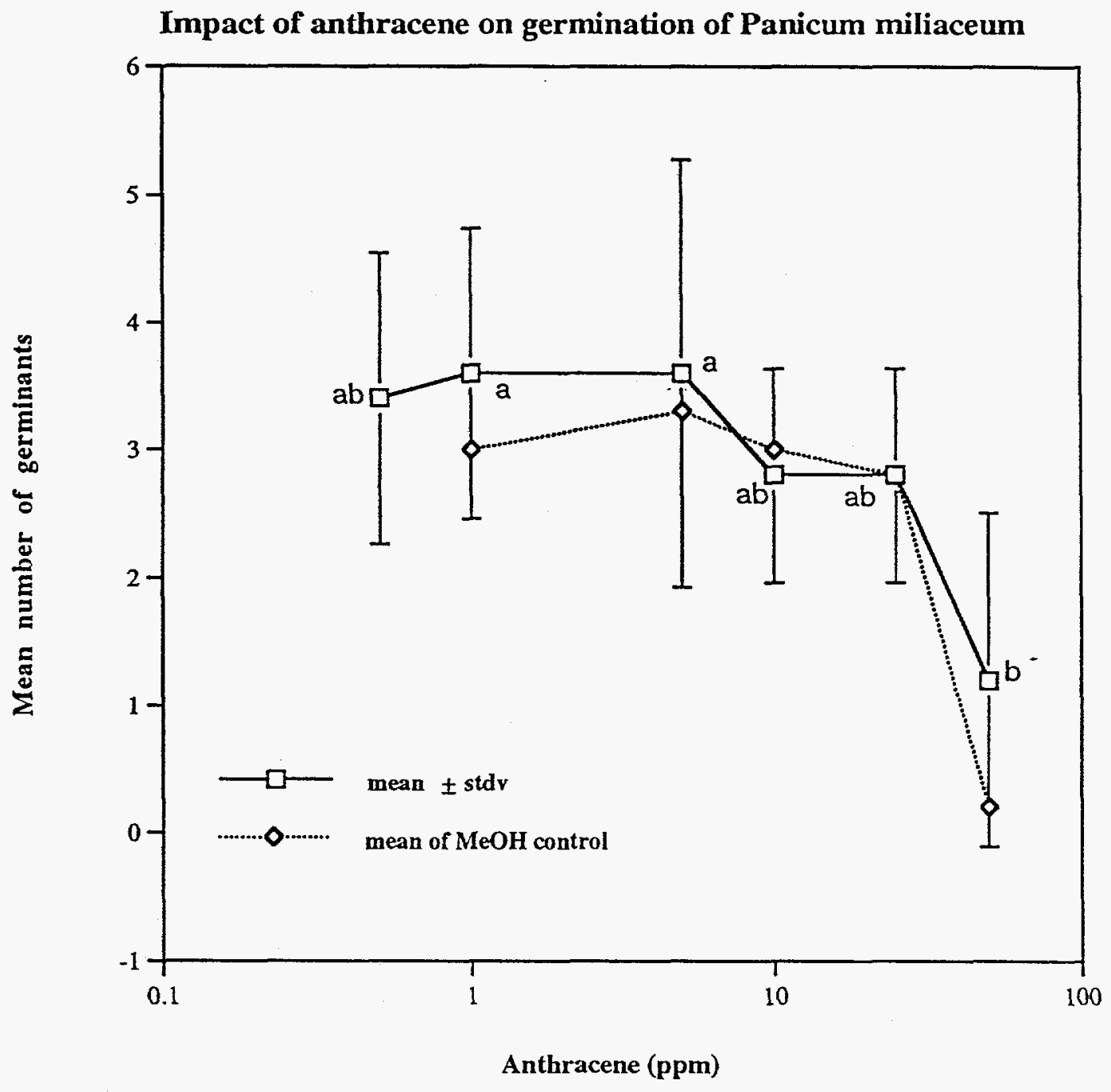


Figure 9.

Impact of atrazine on germination of Panicum miliaceum

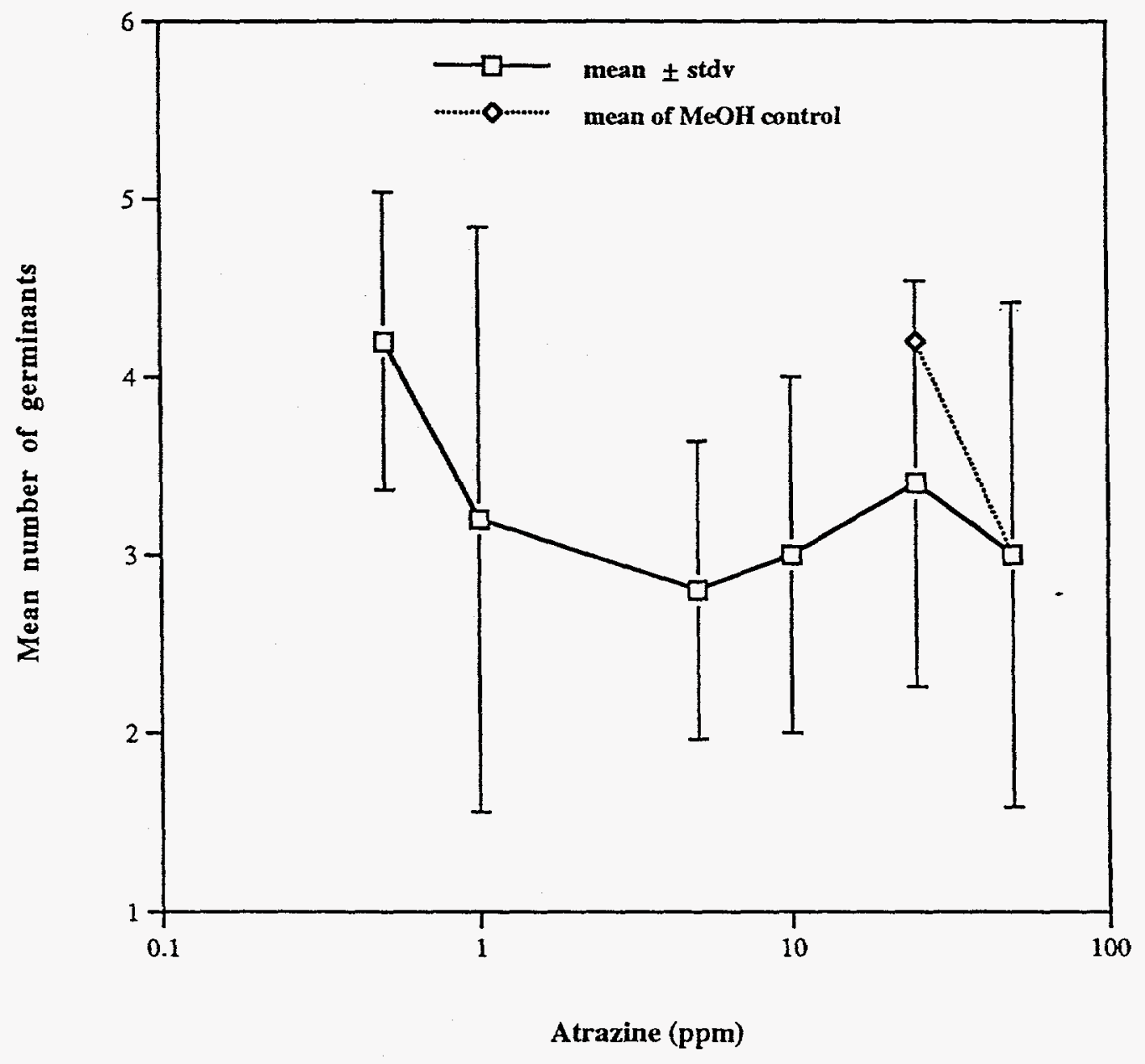


Figure 10.

Impact of pce on germination of Panicum miliaceum

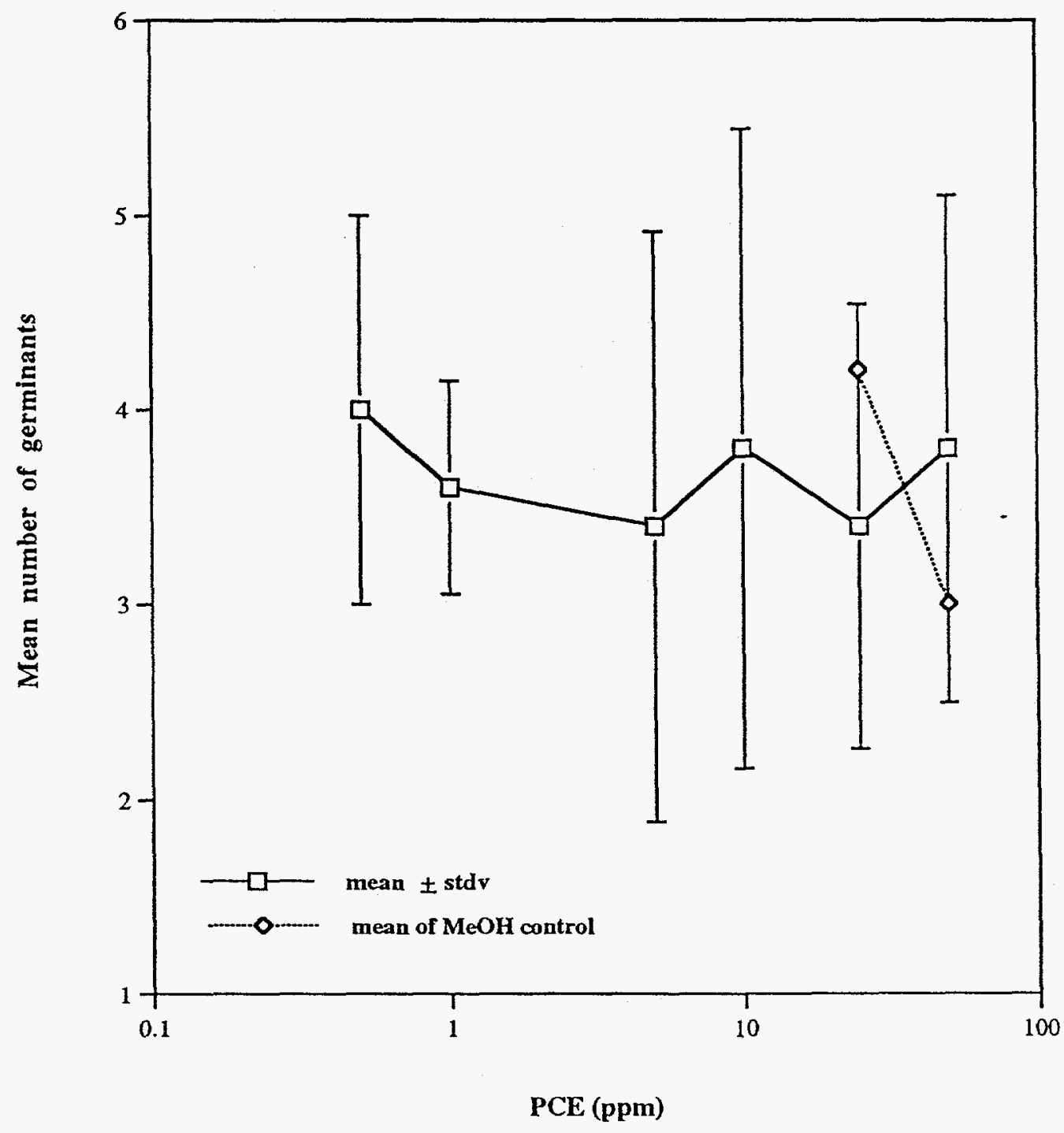


Figure 11.

Impact of cadmium on germination of Raphanus sativus

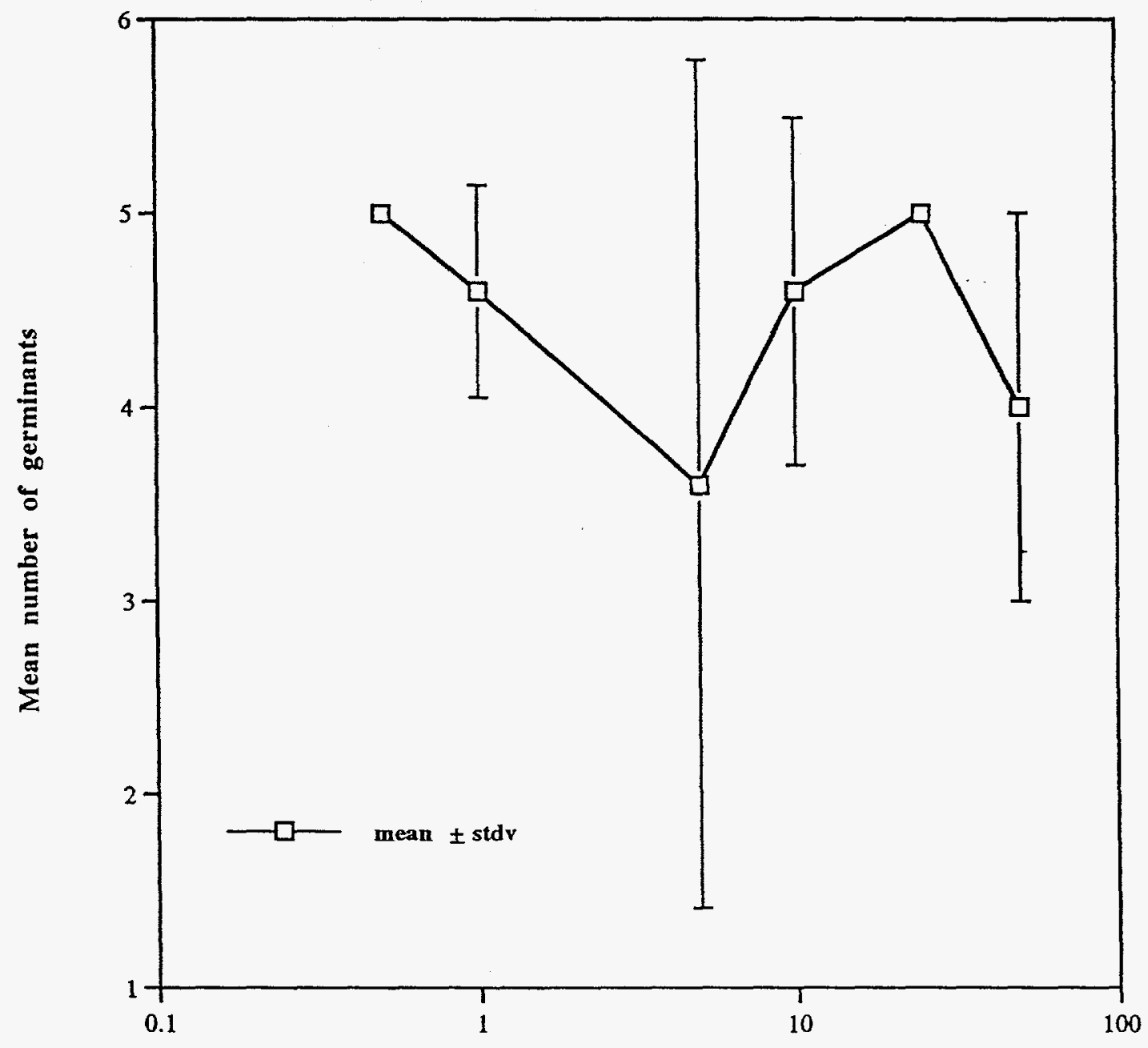

Cd (ppm) 
Figure 12 .

Impact of nickel on germination of Raphanus sativus

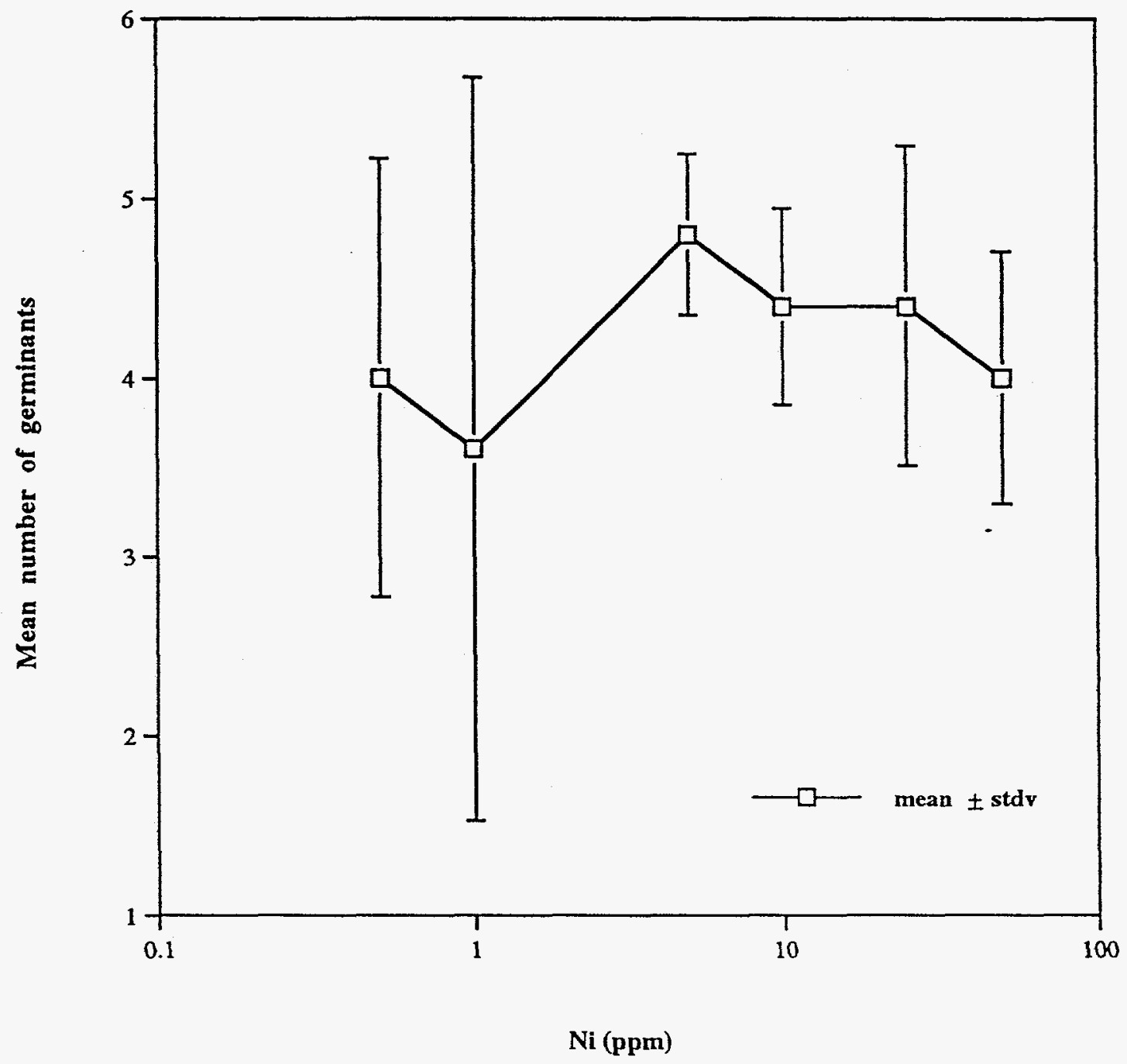


Figure 13.

Impact of anthracene on germination of Raphanus sativus

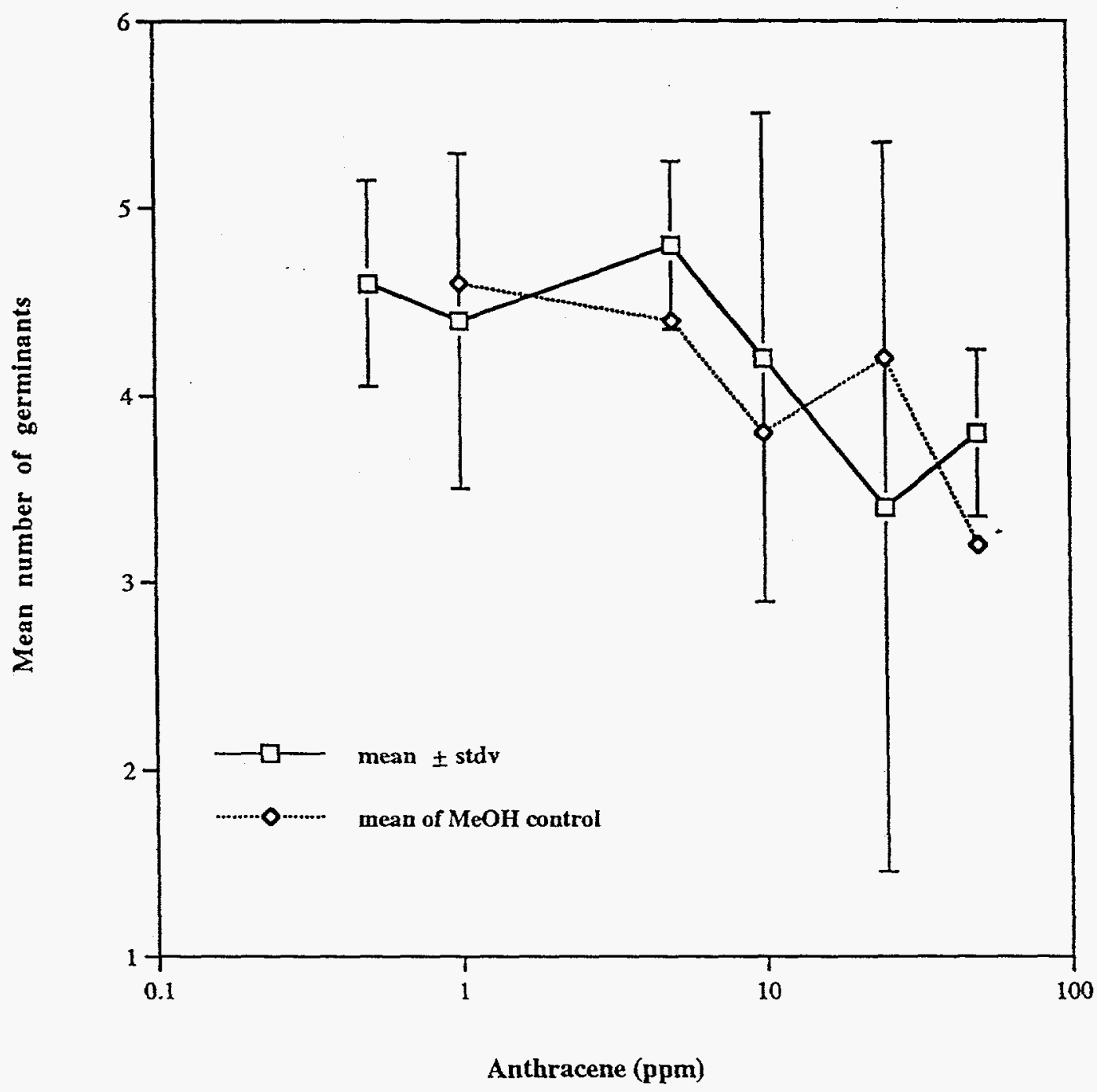


Figure 14.

Impact of atrazine on germination of Raphanus sativus

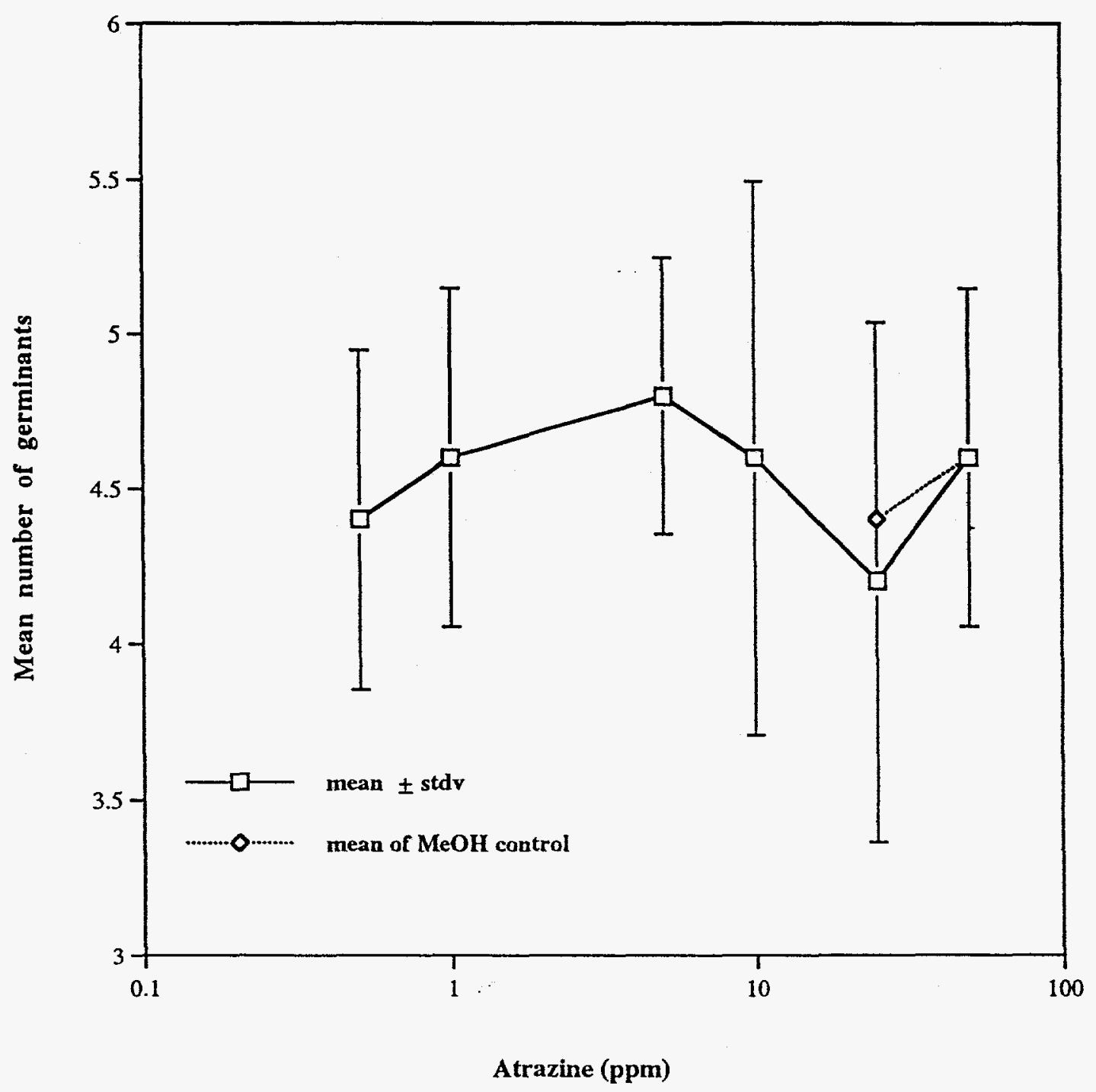


Figure 15.

Impact of pce on germination of Raphanus sativus

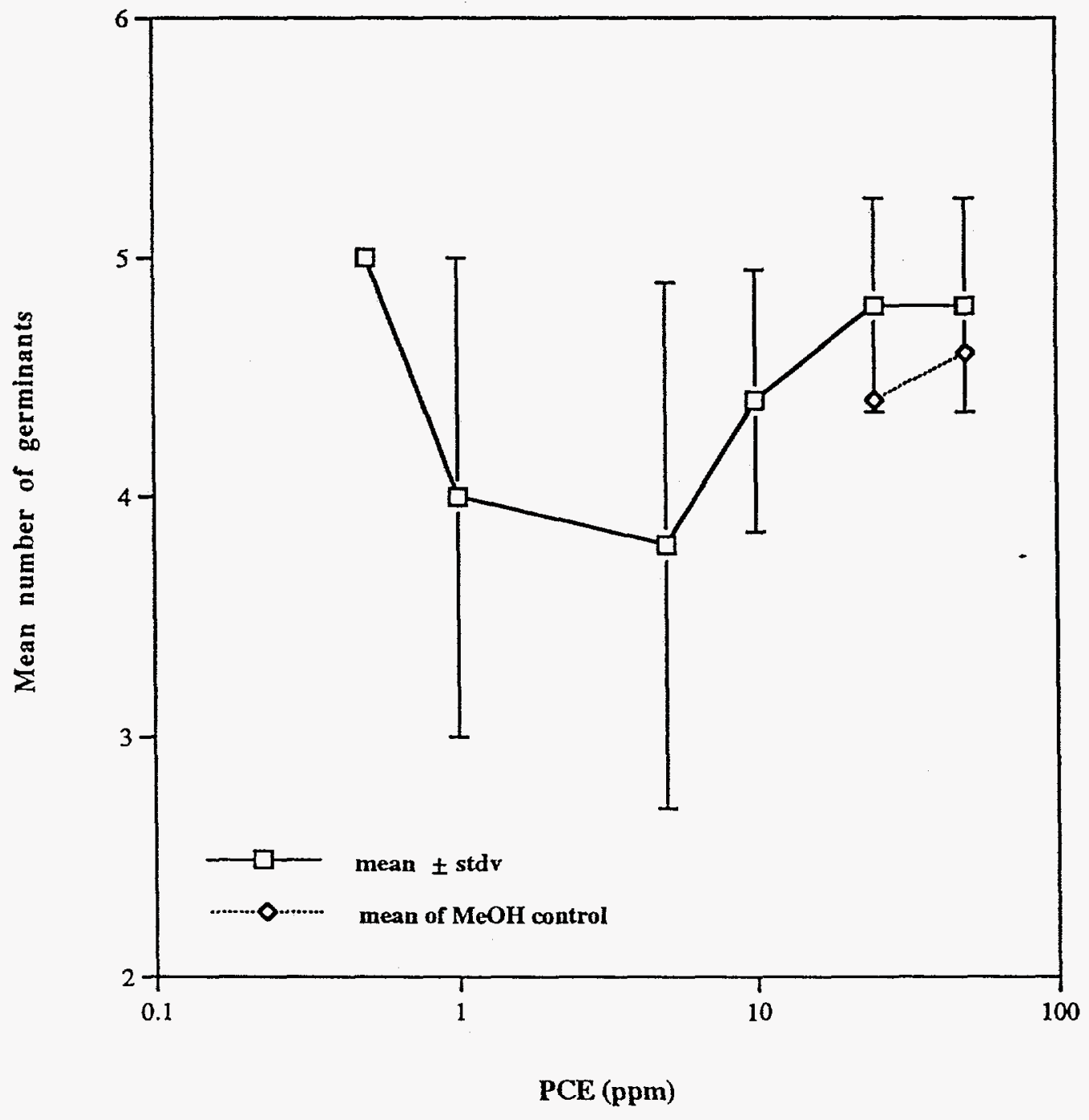


Figure 16.

Impact of cadmium on germination of Saururus cernuus

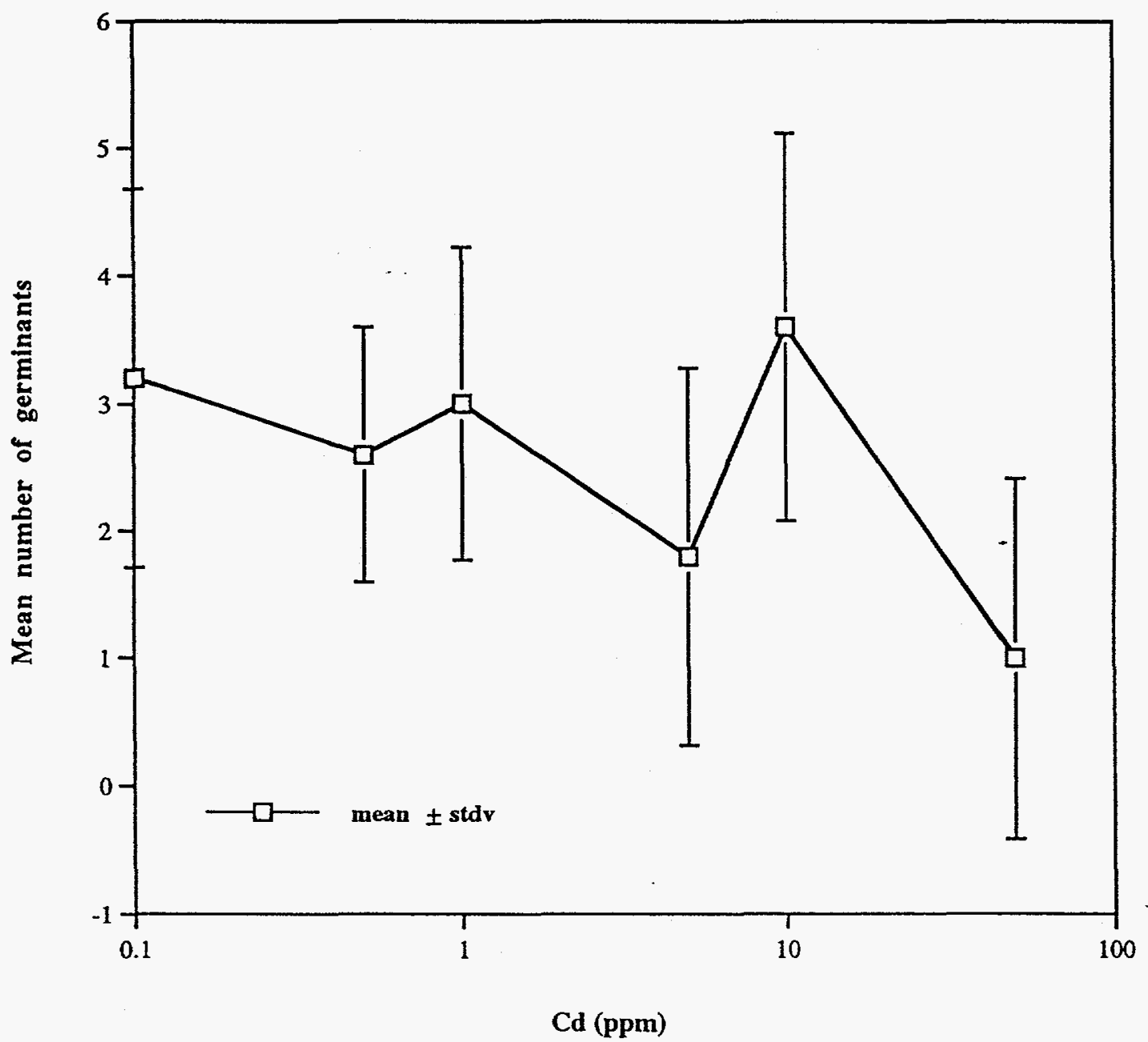


Figure 17.

Impact of nickel on germination of Saururus cernuus

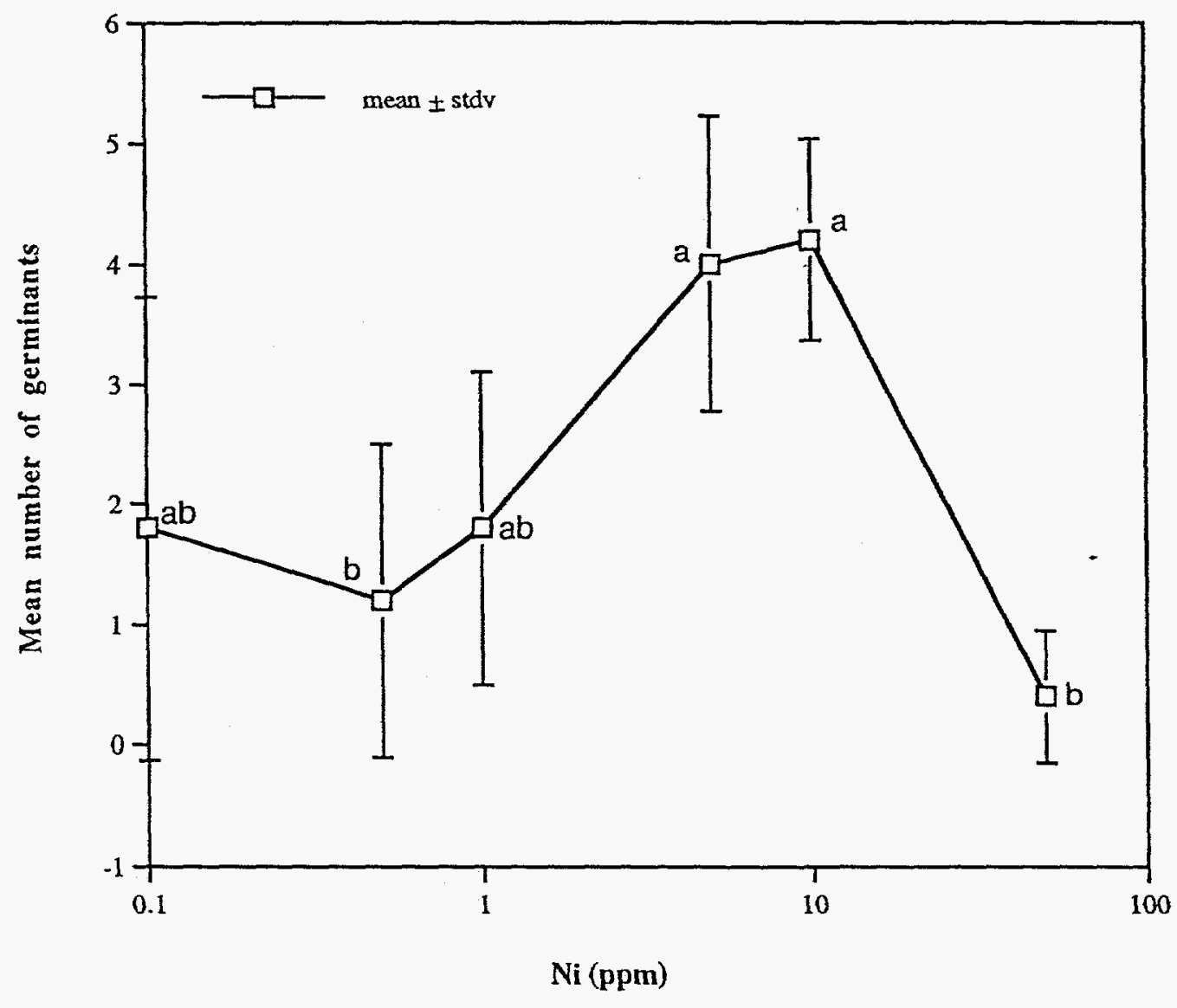


Figure 18 .

Impact of anthracene on germination of Saururus cernuus

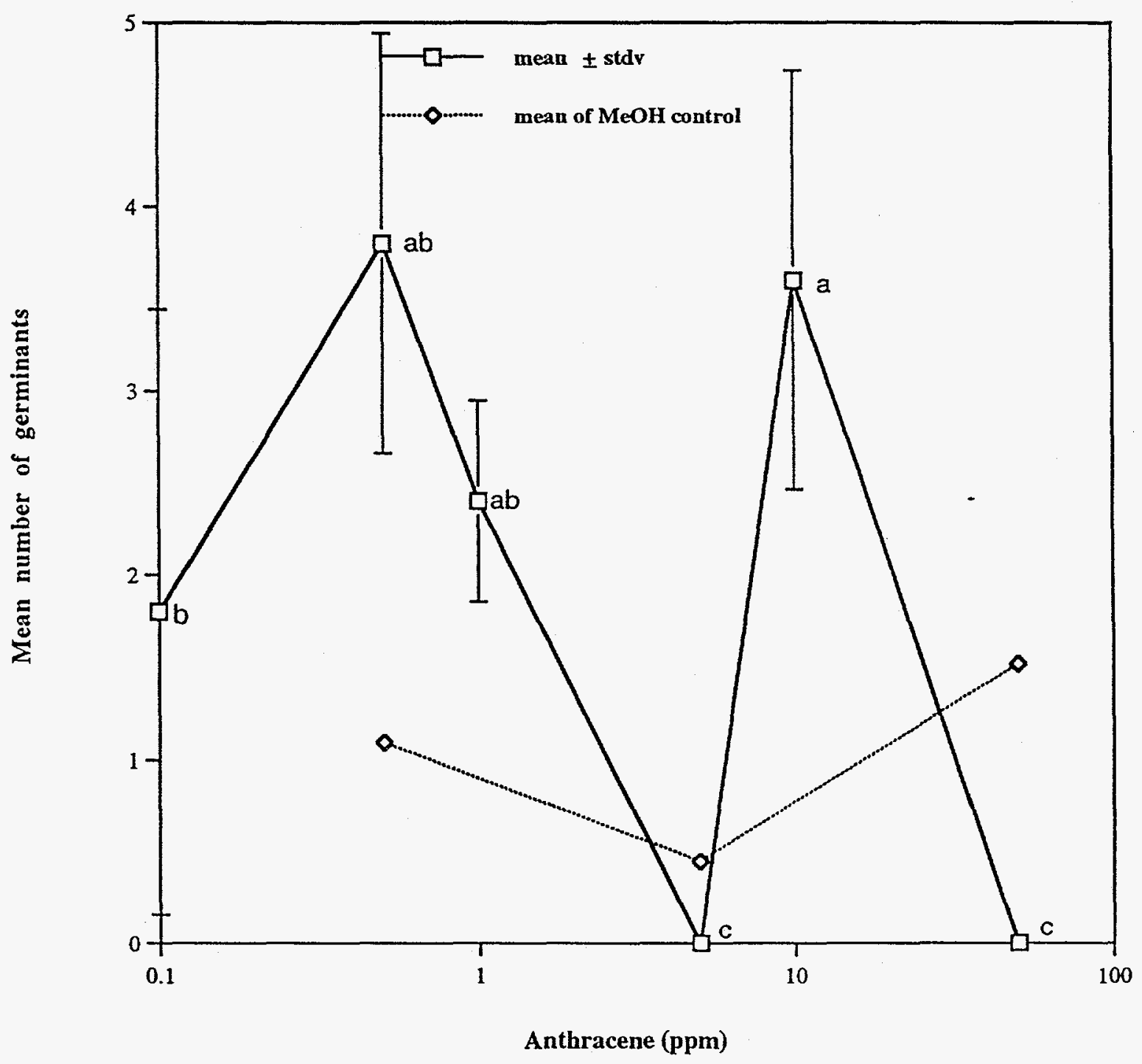


Figure 19.

Impact of atrazine on germination of Saururus cernuus

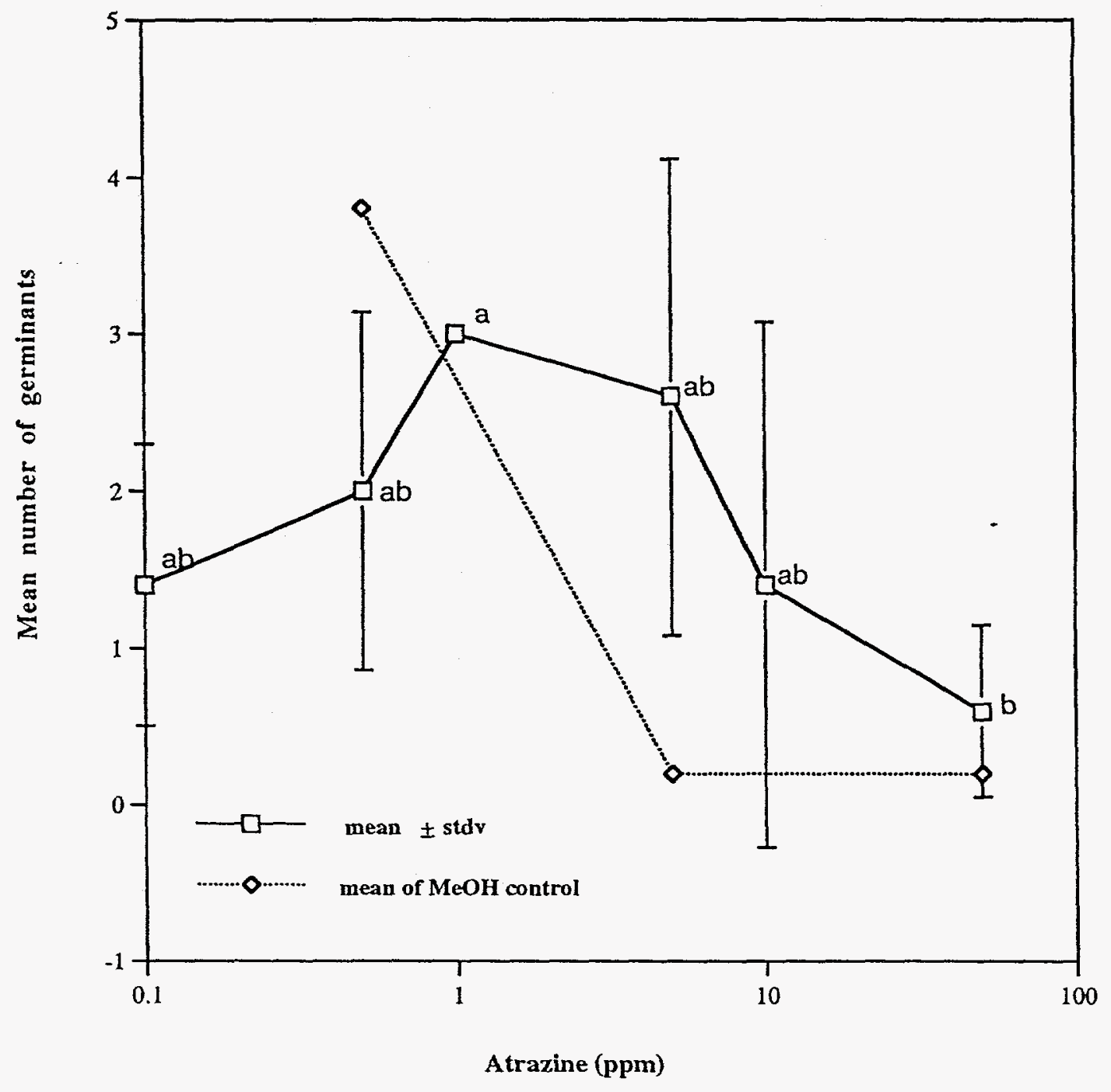


Figure 20.

Impact of pce on germination of Saururus cernuus

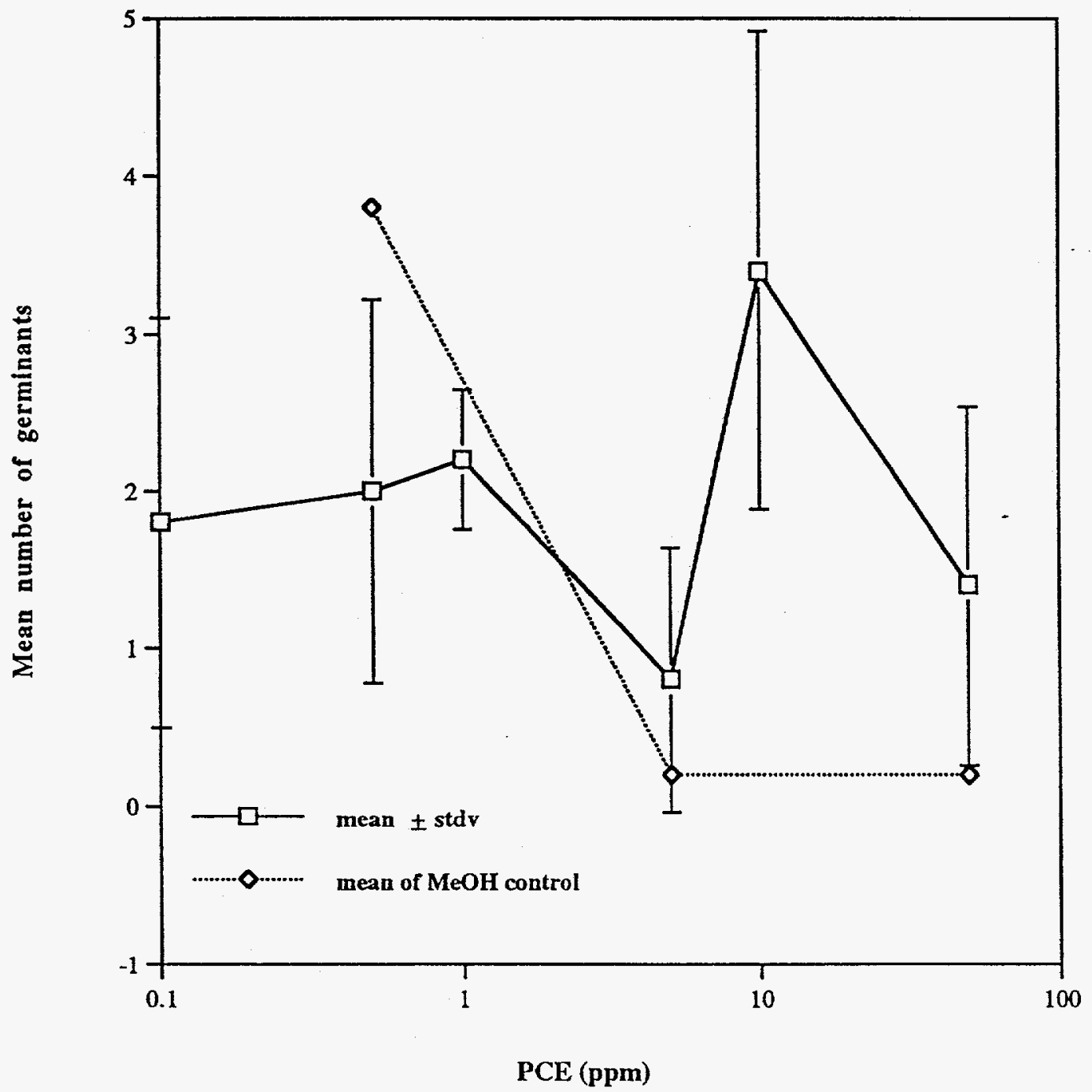


Figure 21.

Impact of cadmium on germination of Lactuca sativa

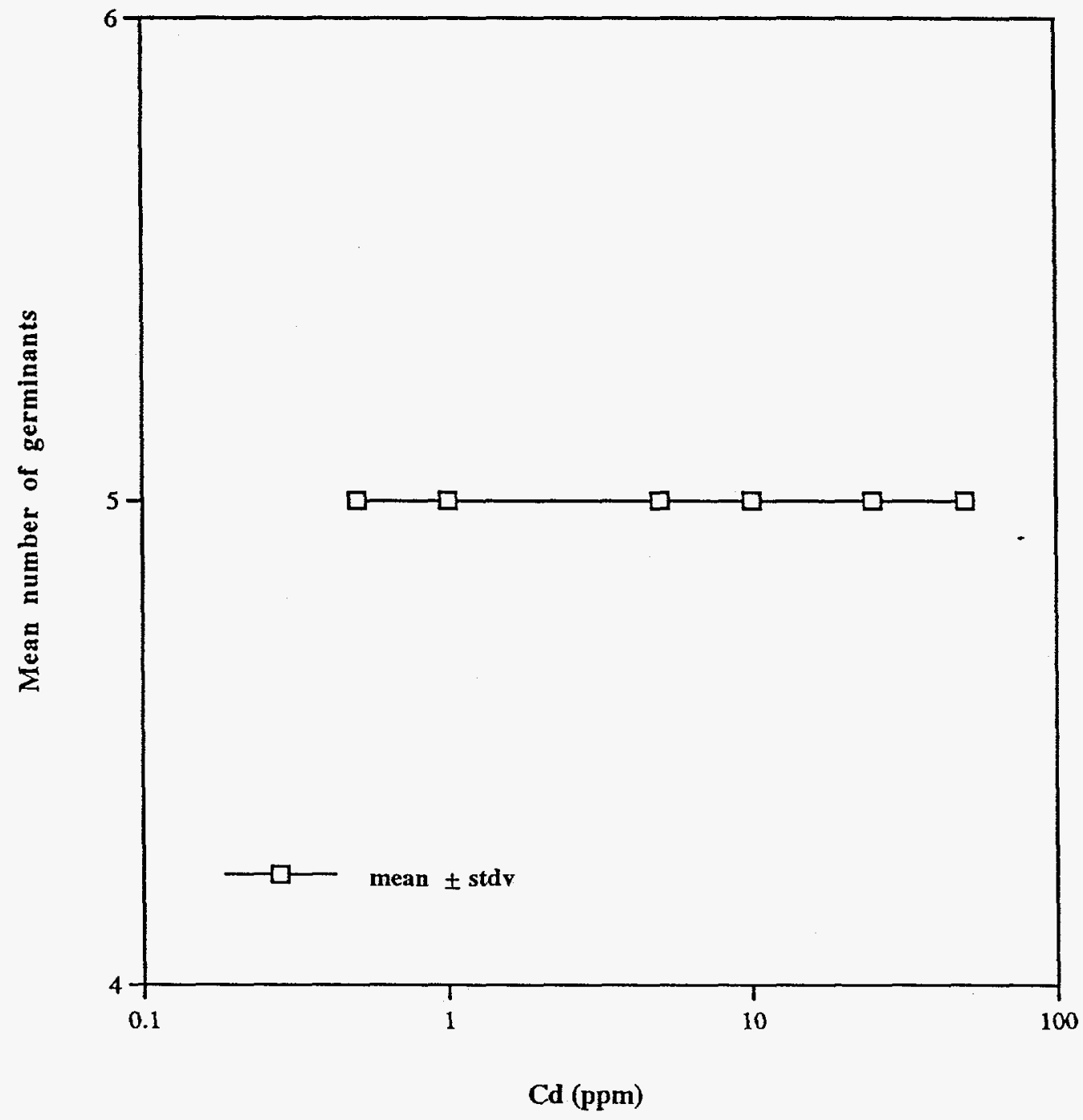


Figure 22.

Impact of nickel on germination of Lactuca sativa

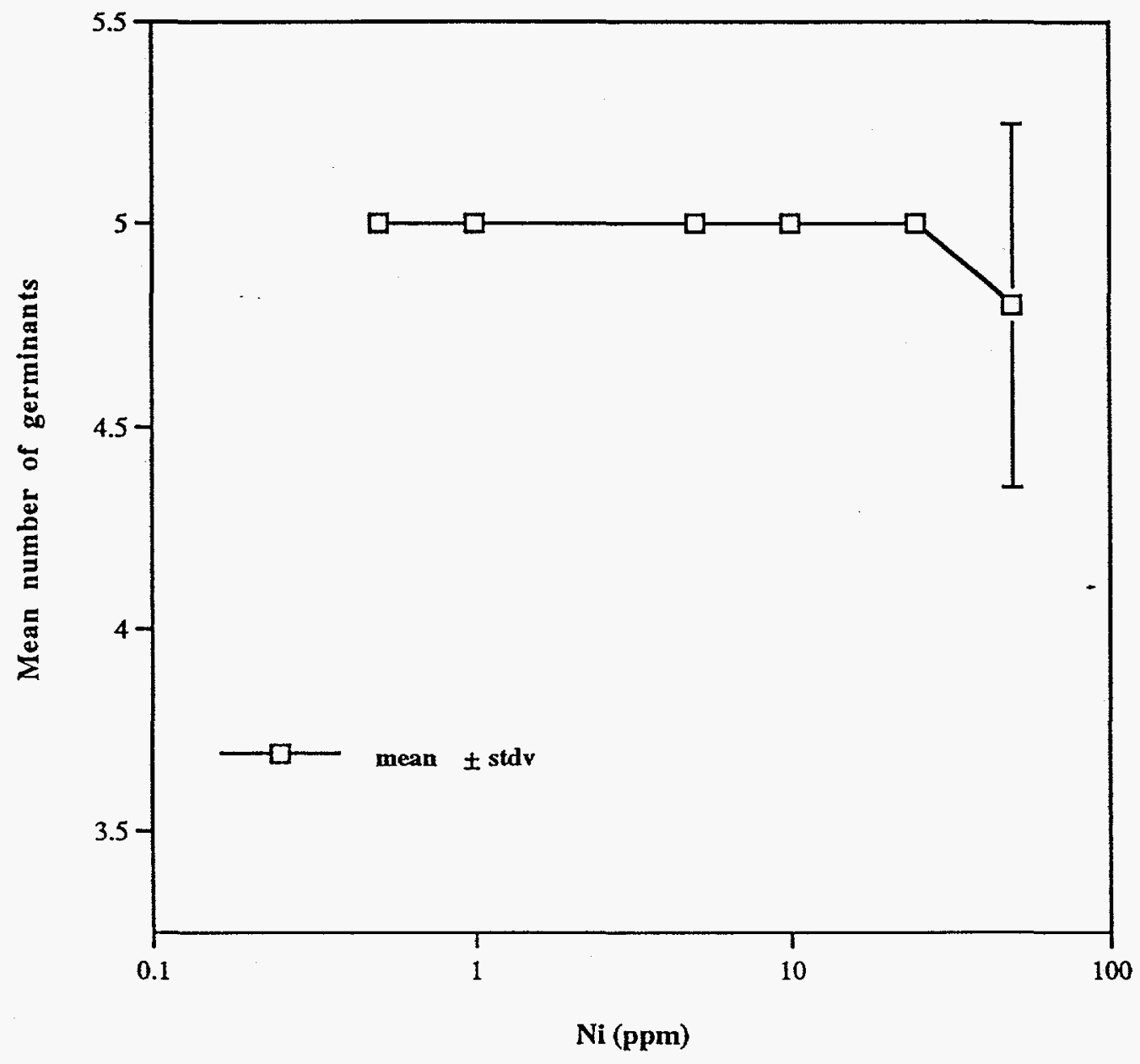


Figure 23.

Impact of anthracene on germination of Lactuca sativa

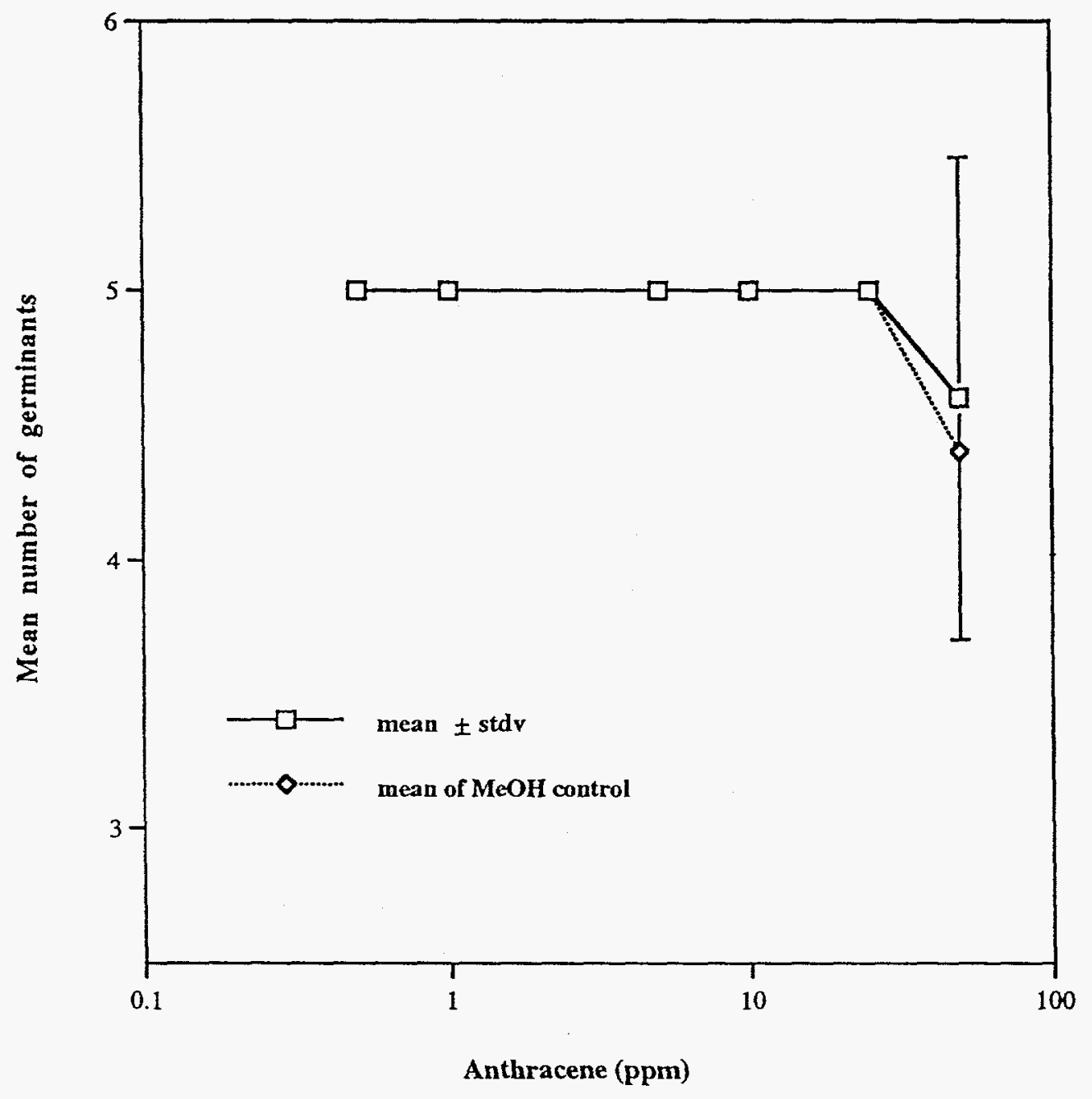


Figure 24 .

Impact of atrazine on germination of Lactuca sativa

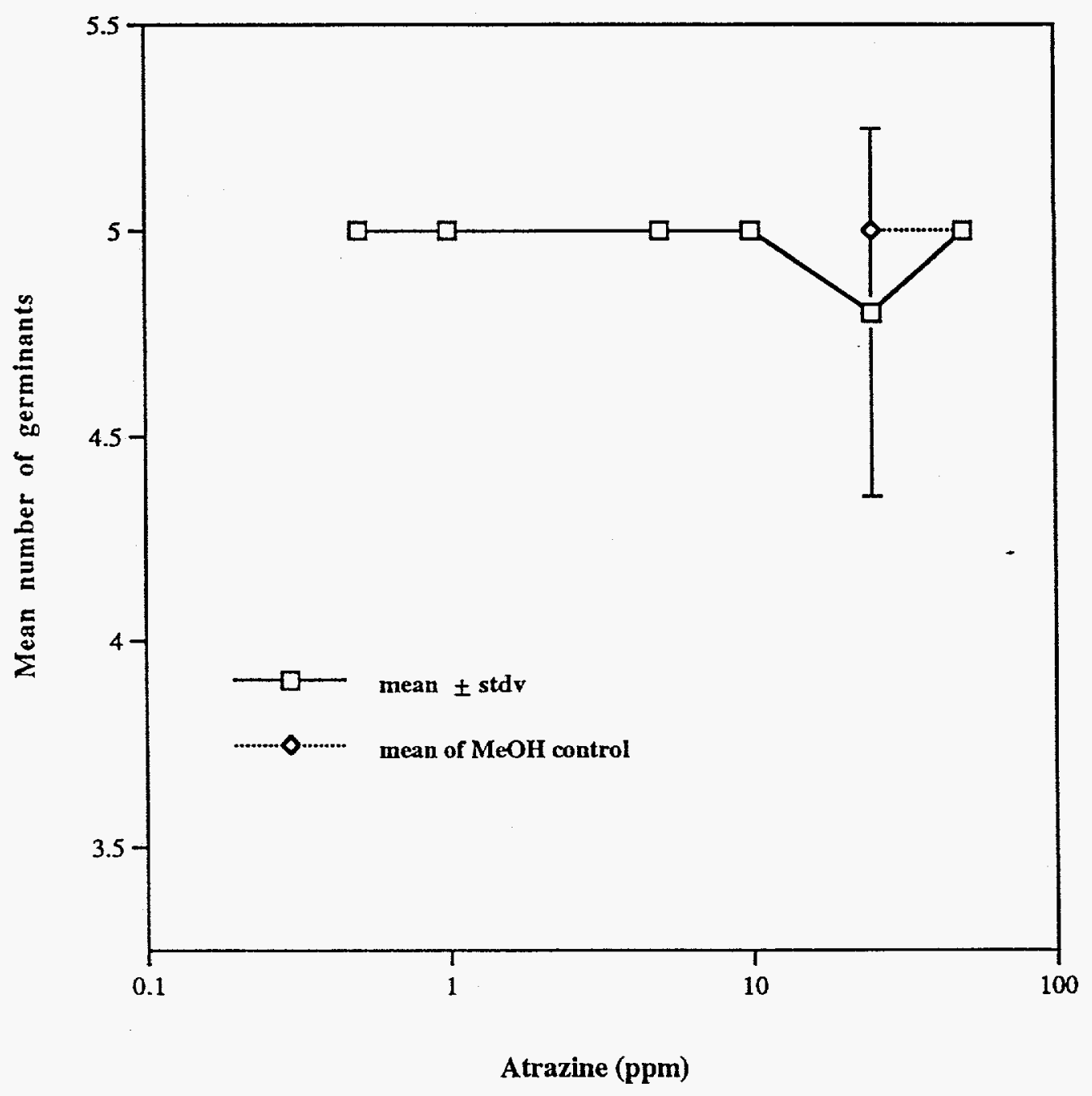


Figure 25.

Impact of pce on germination of Lactuca sativa

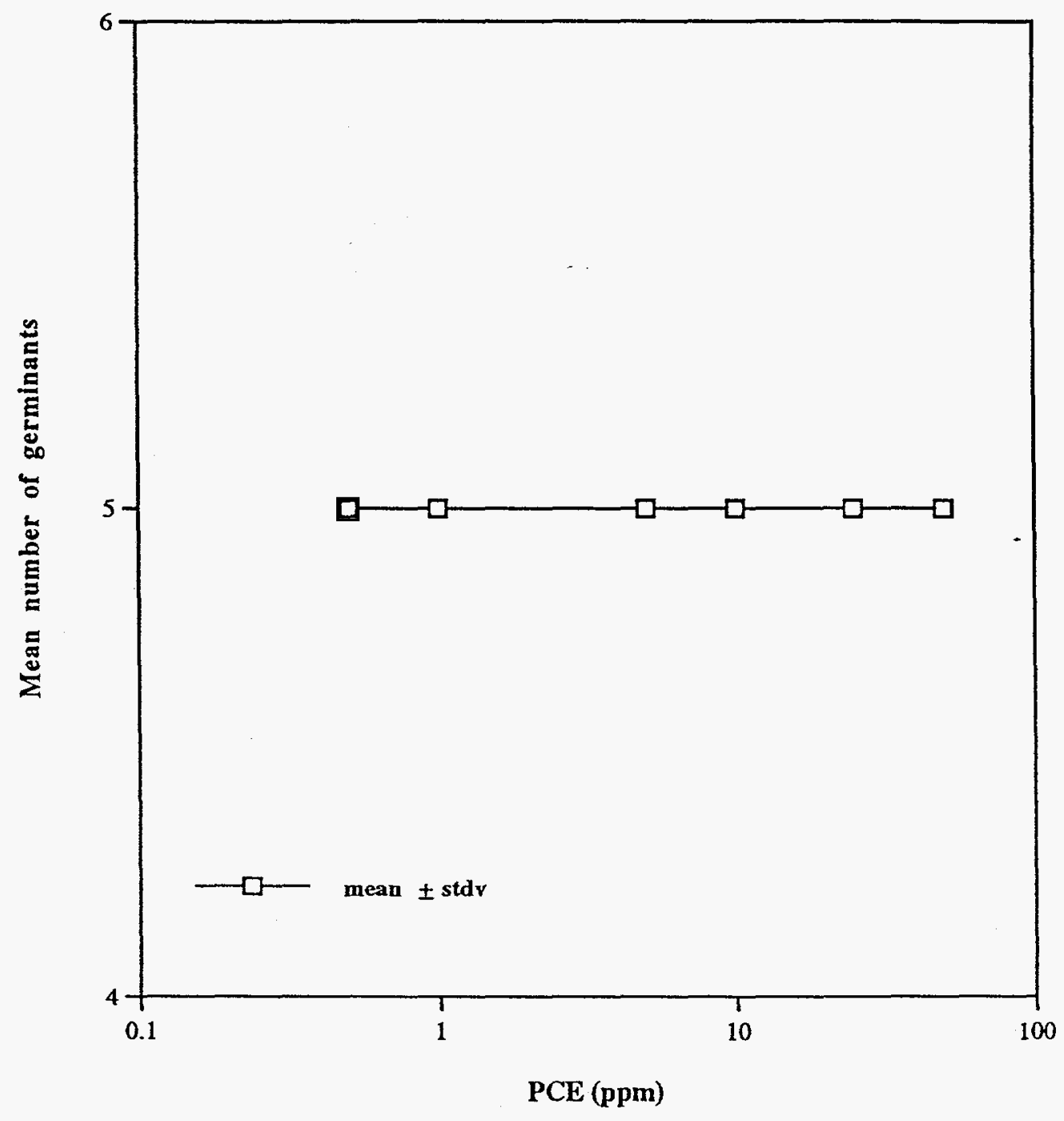


Figure 26.

Impact of cadmium on germination of Quercus falcata

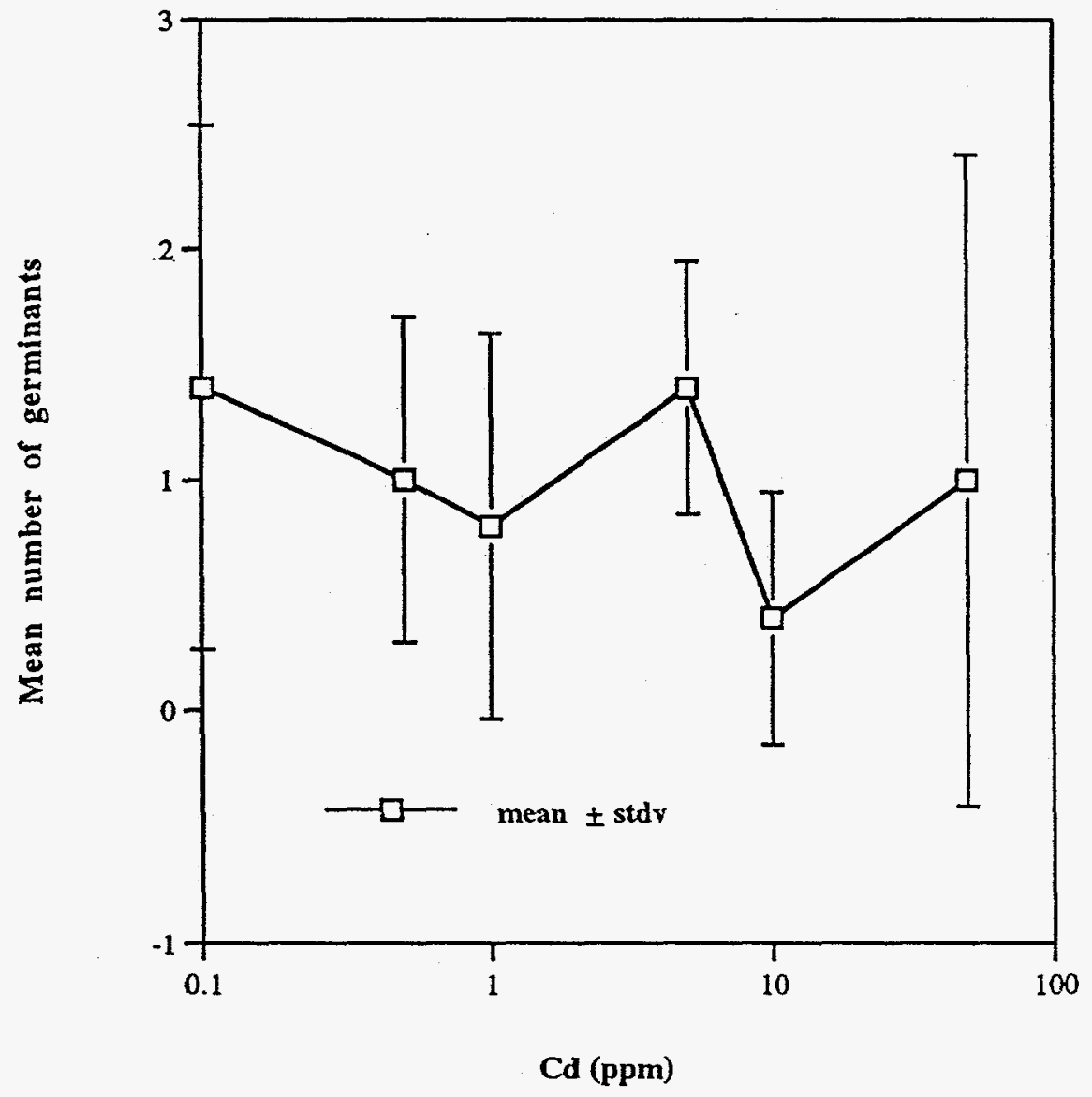


Figure 27.

Impact of nickel on germination of Quercus falcata

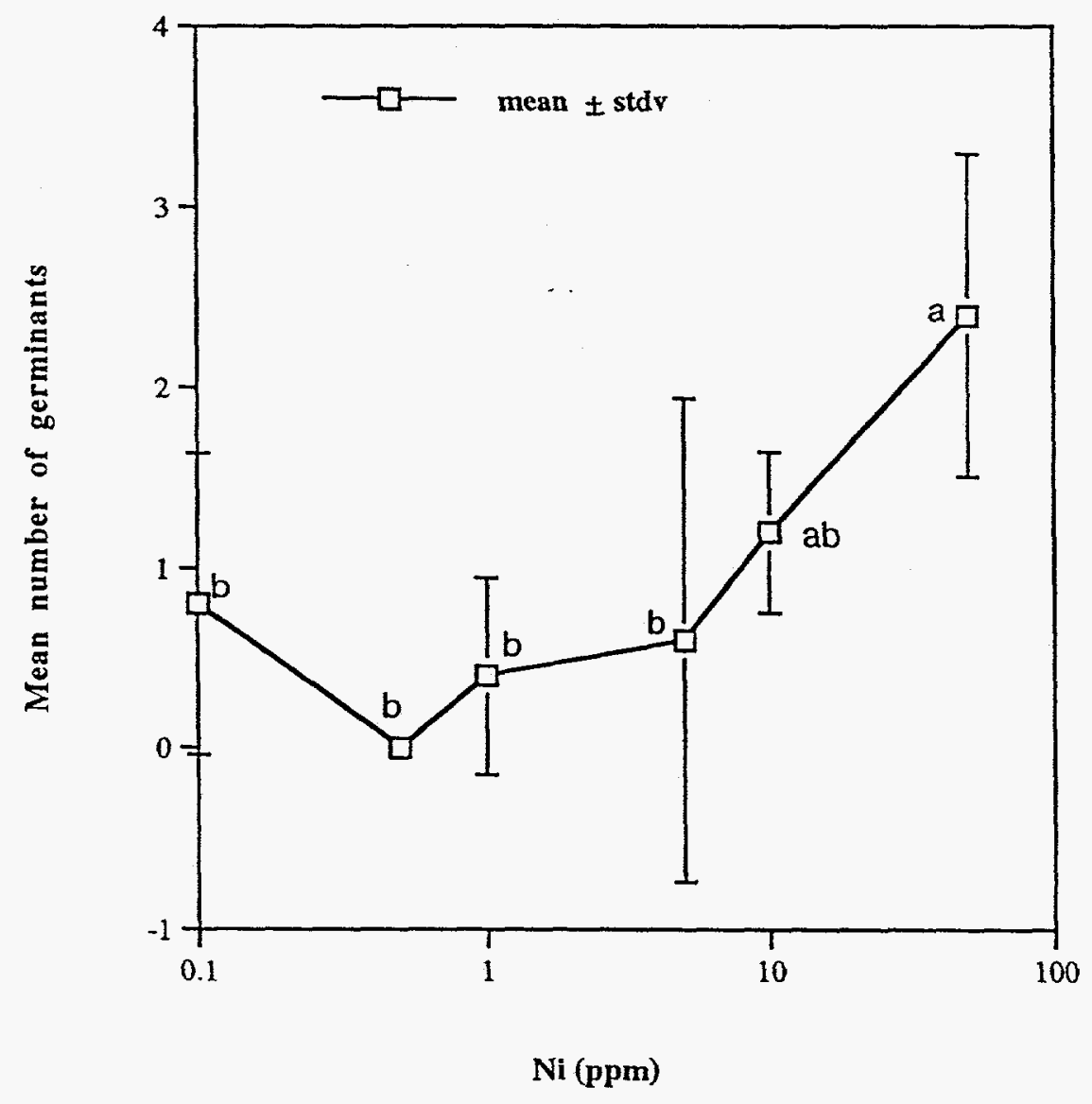


Figure 28 .

Impact of anthracene germination of Quercus falcata

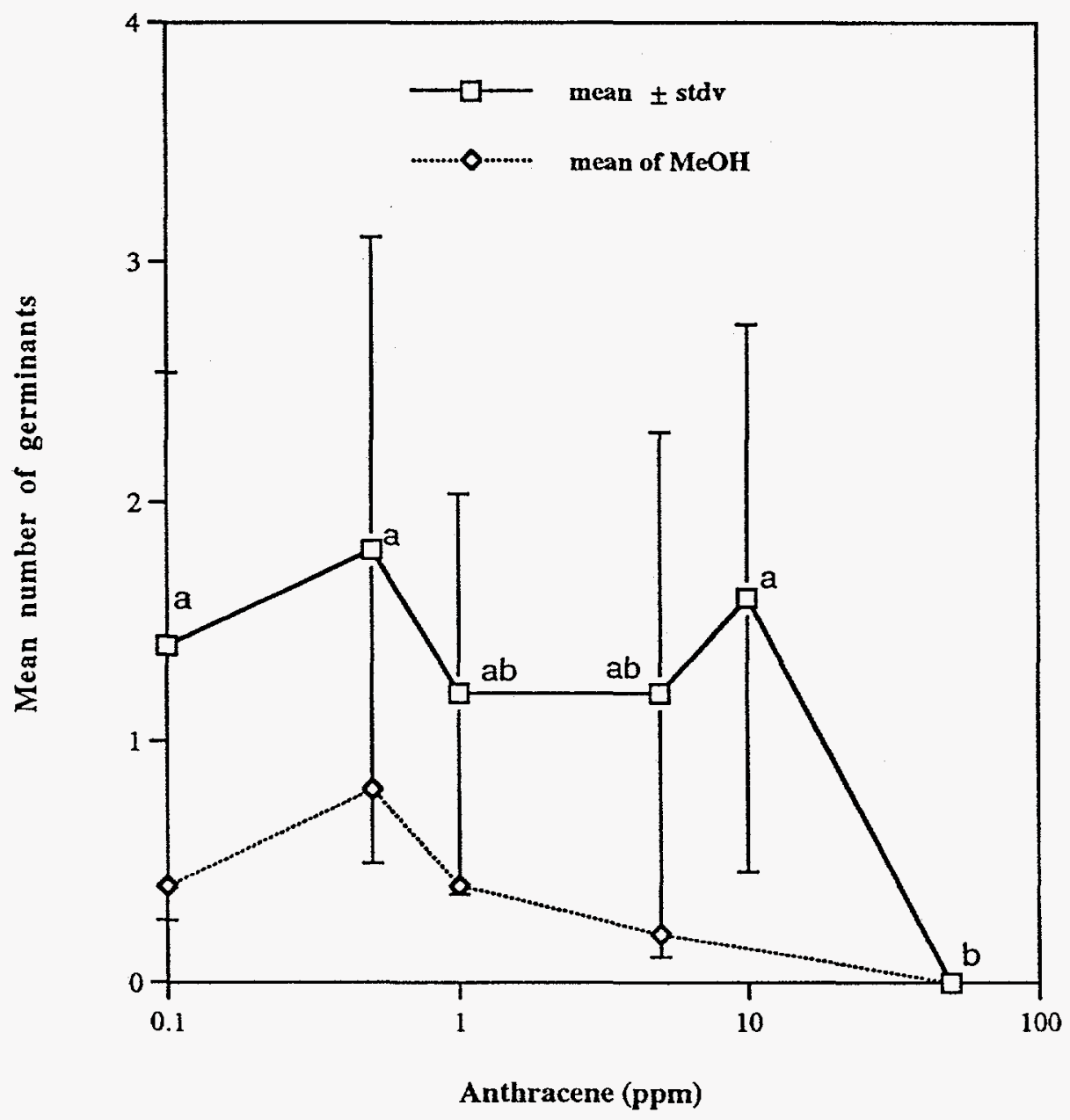


Figure 29.

Impact of atrazine on germination of Quercus falcata

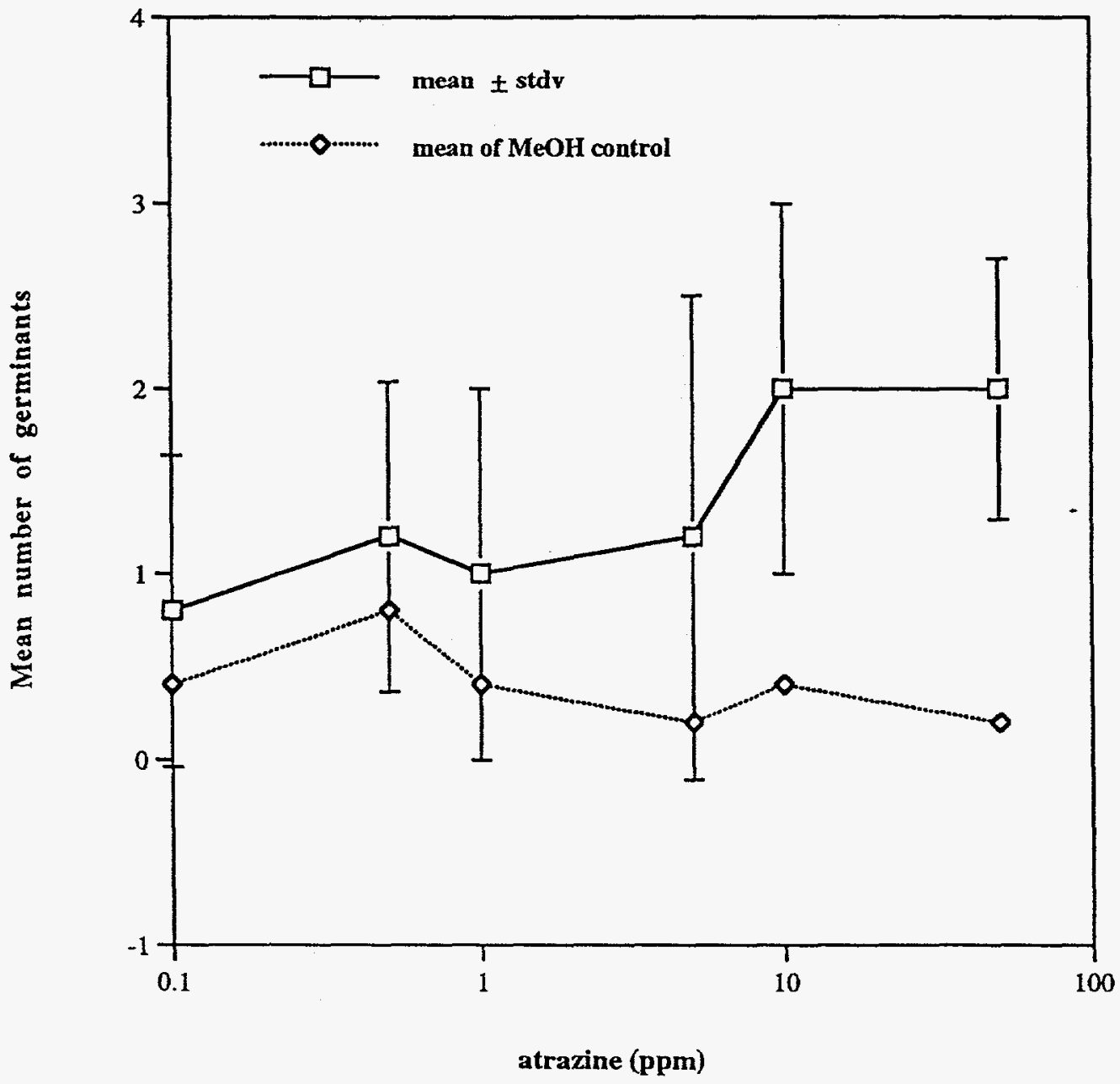


Figure 30 .

Impact of pce on germination of Quercus falcata

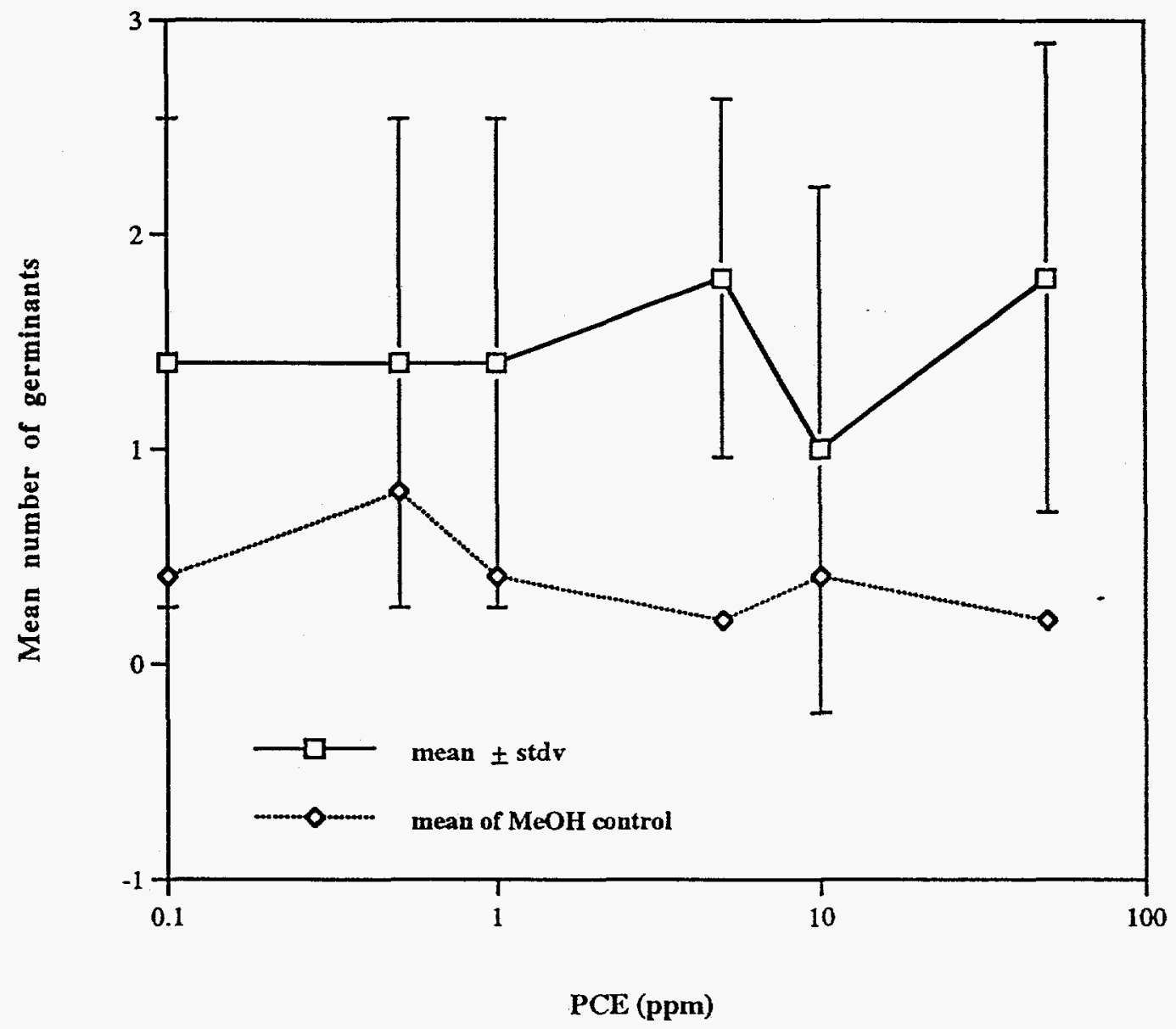


Figure 31.

Impact of cadmium on germination of Cephalanthus occidentalis

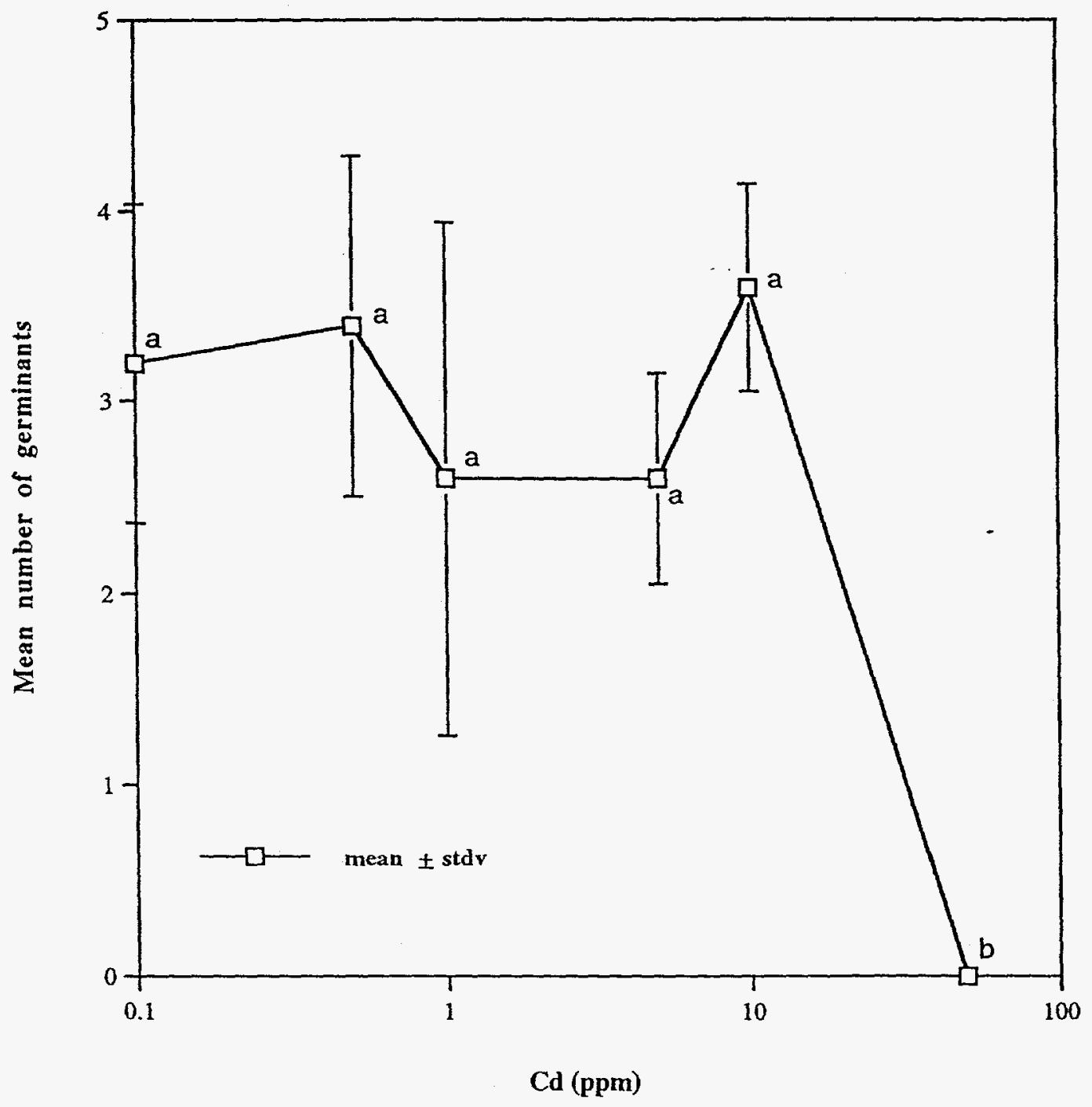


Figure 32.

Impact of nickel on germination of Cephalanthus occidentalis

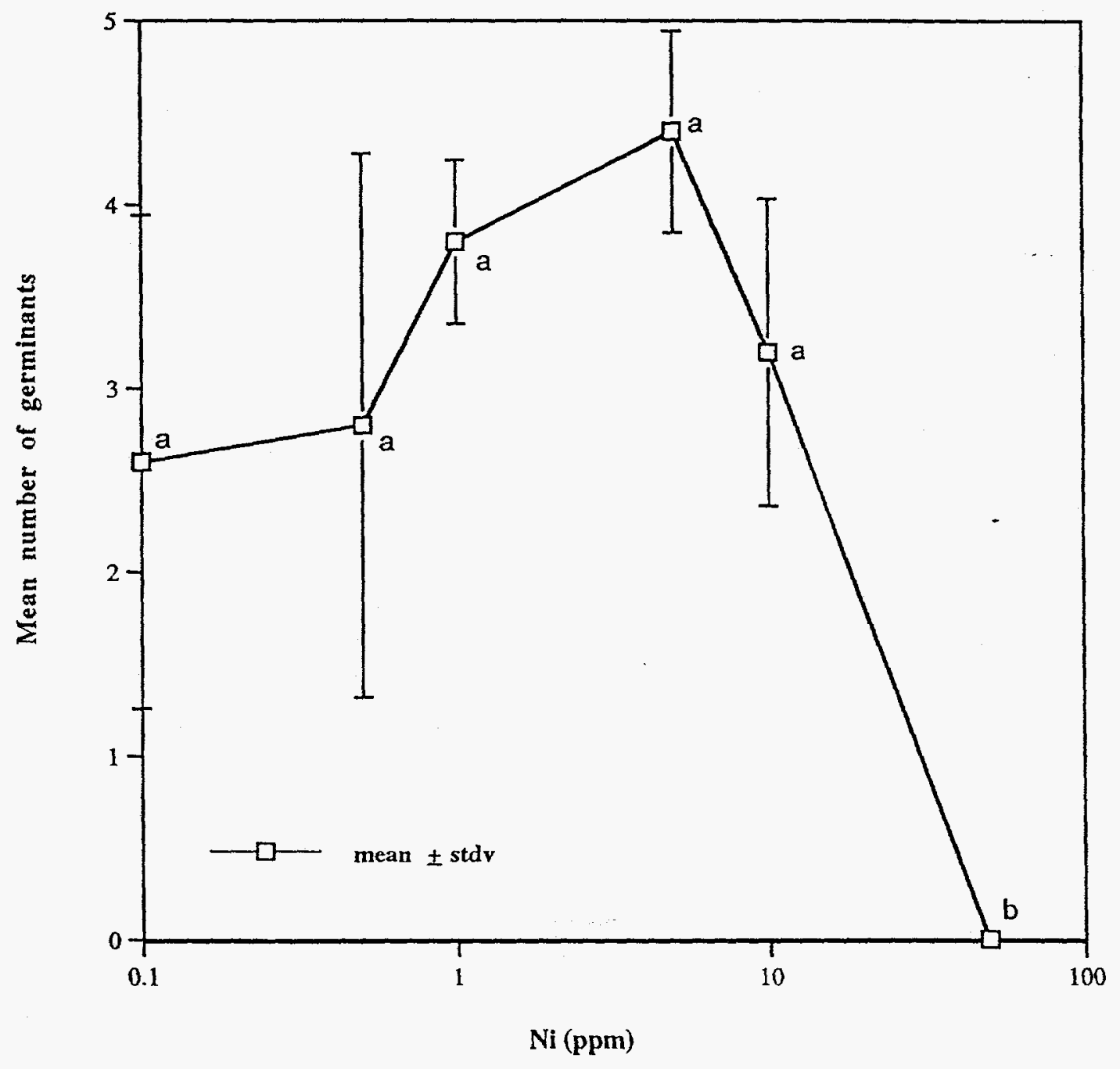


Figure 33.

Impact of anthracene on germination of Cephalanthus occidentalis

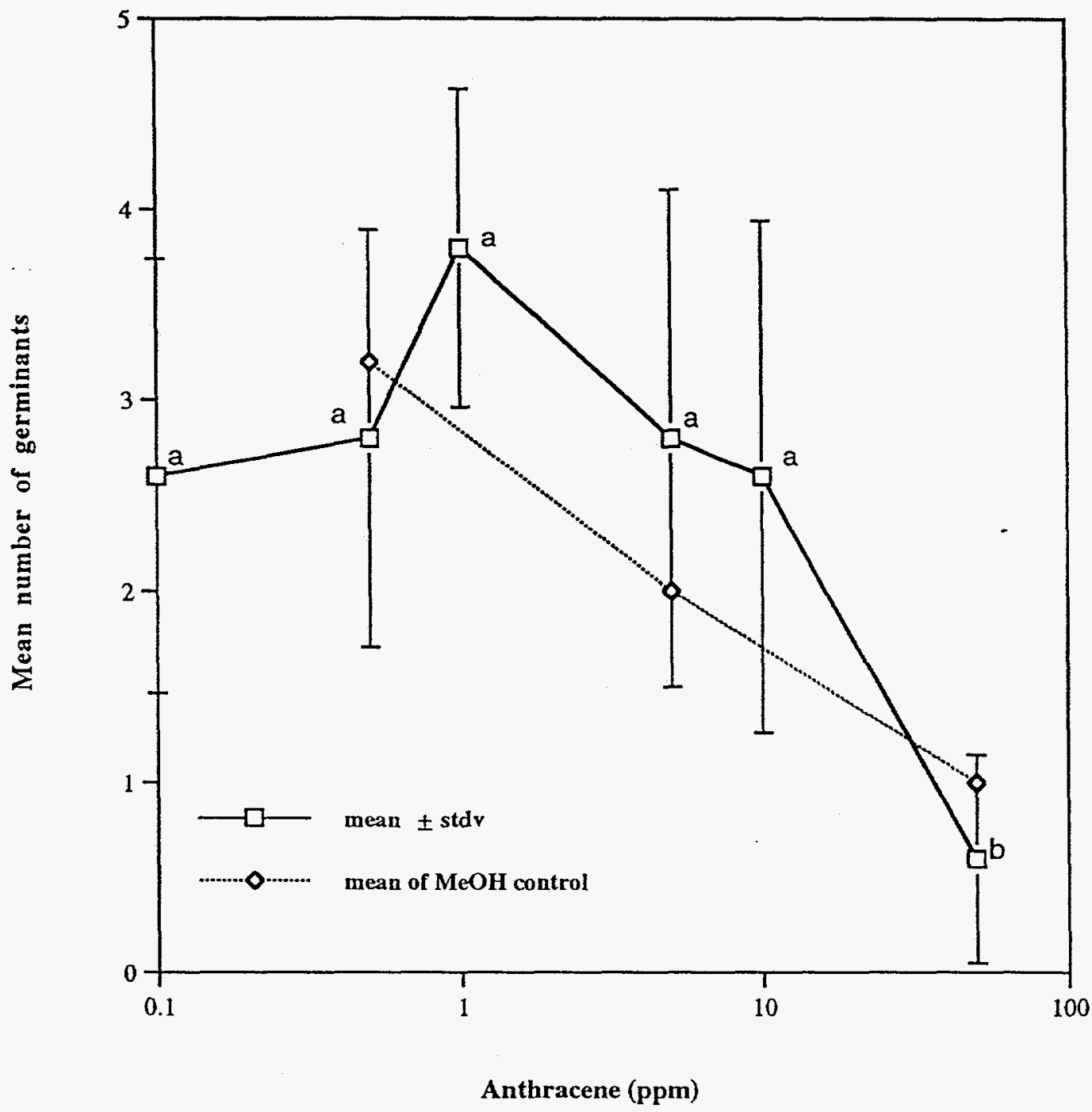


Figure 34.

Impact of atrazine on germination of Cephalanthus occidentalis

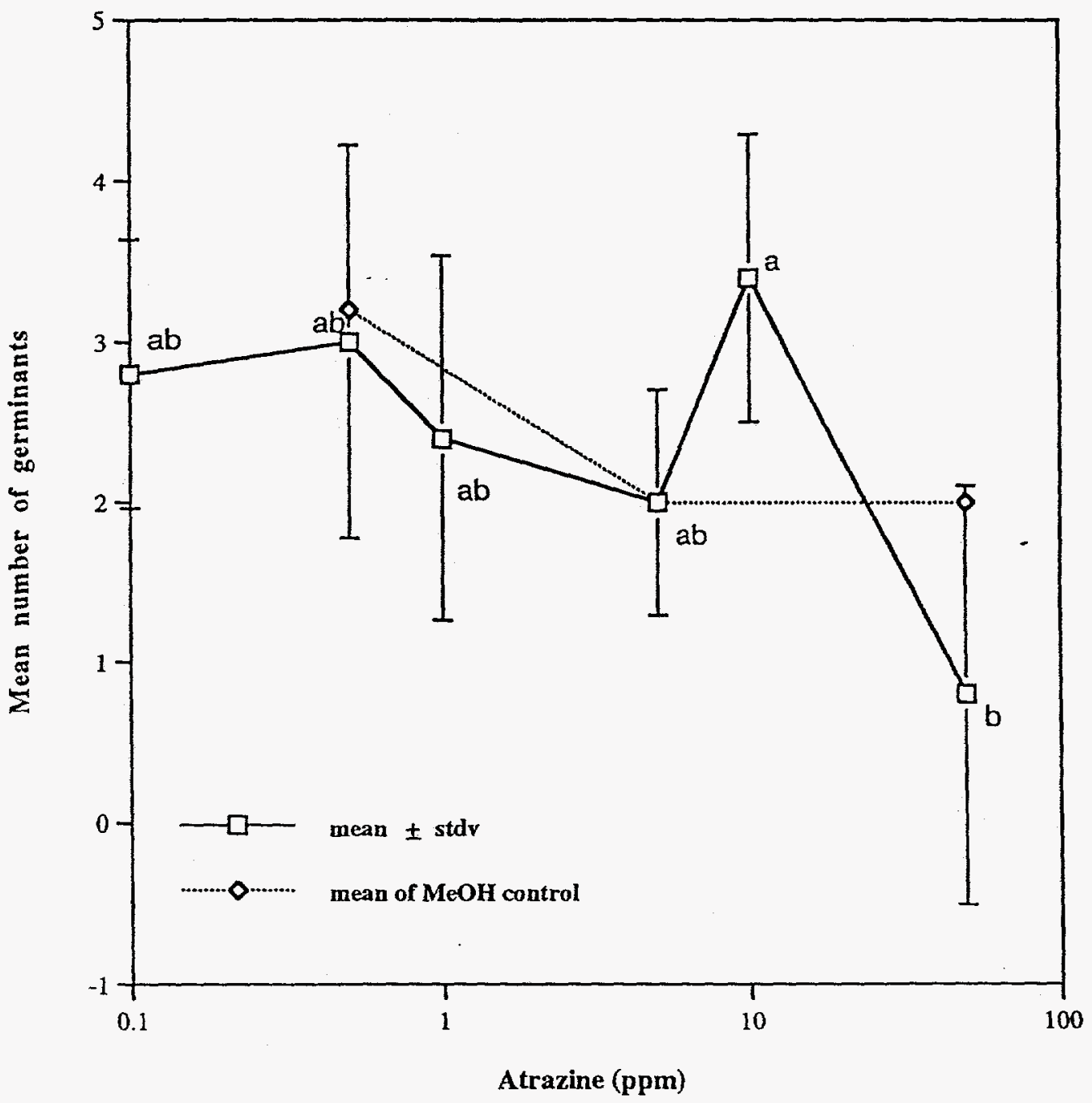


Figure 35.

Impact of pce on germination of Cephalanthus occidentalis

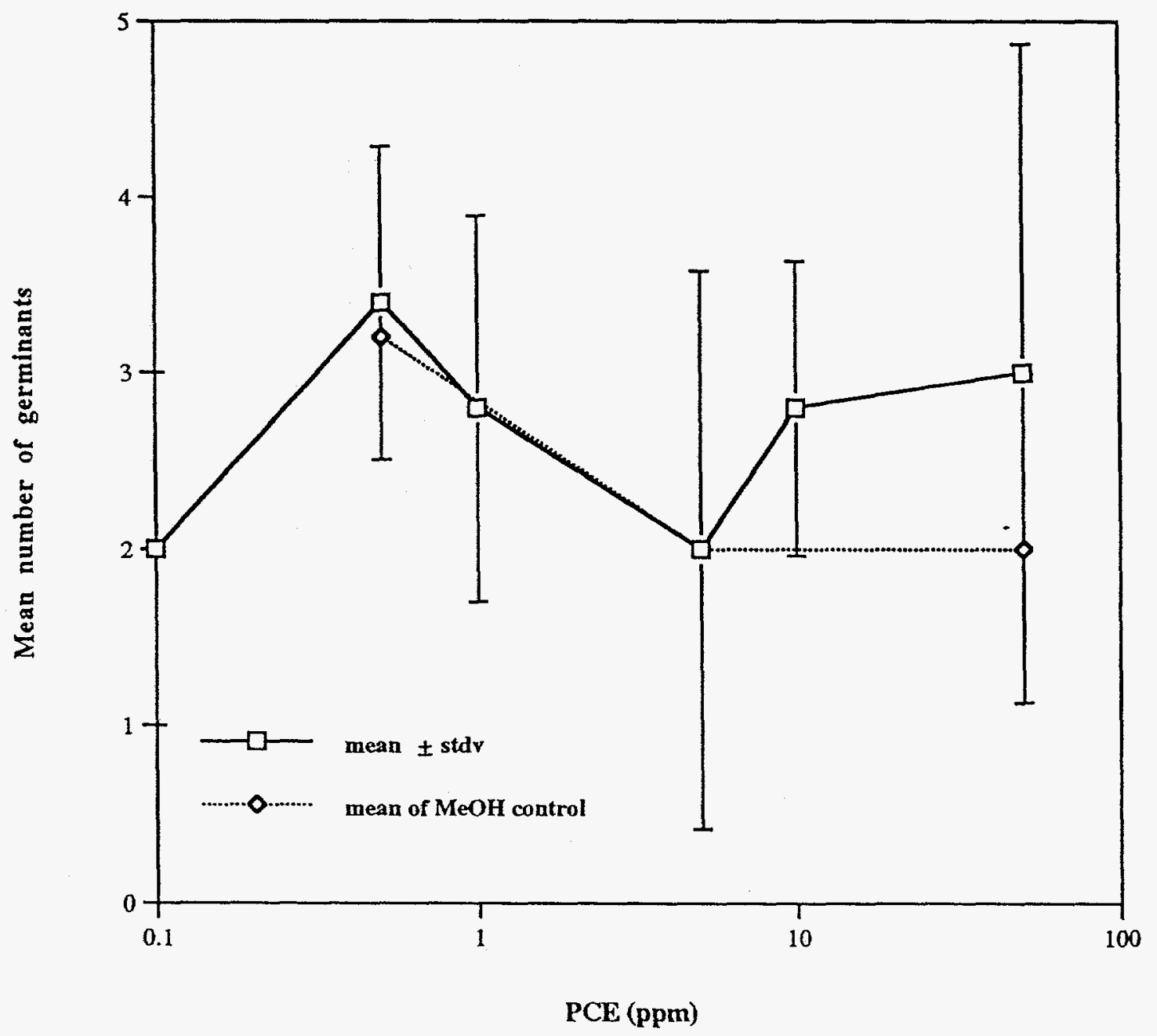


Figure 36.

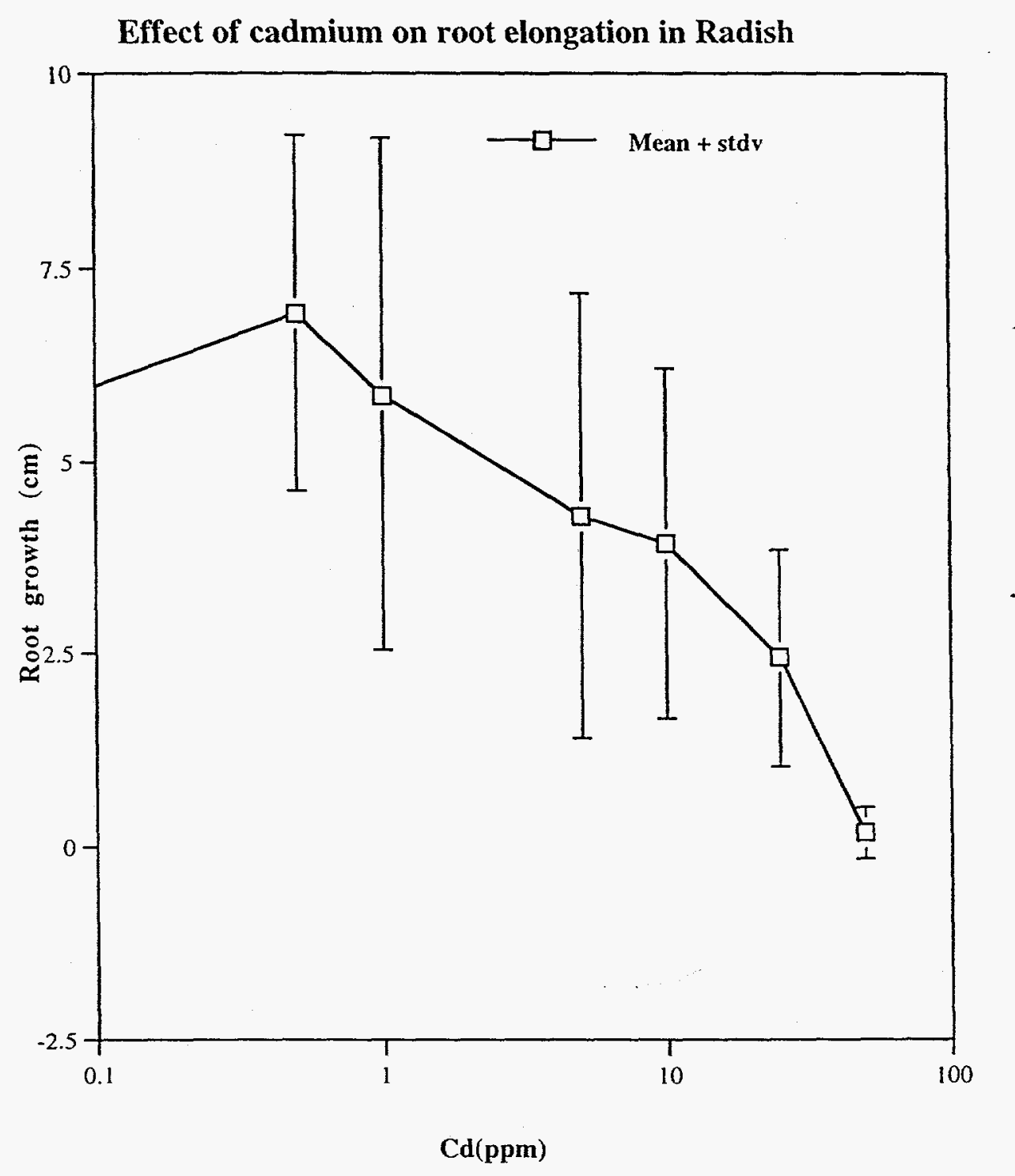


Figure 37.

Effect of nickel on root elongation in Radish

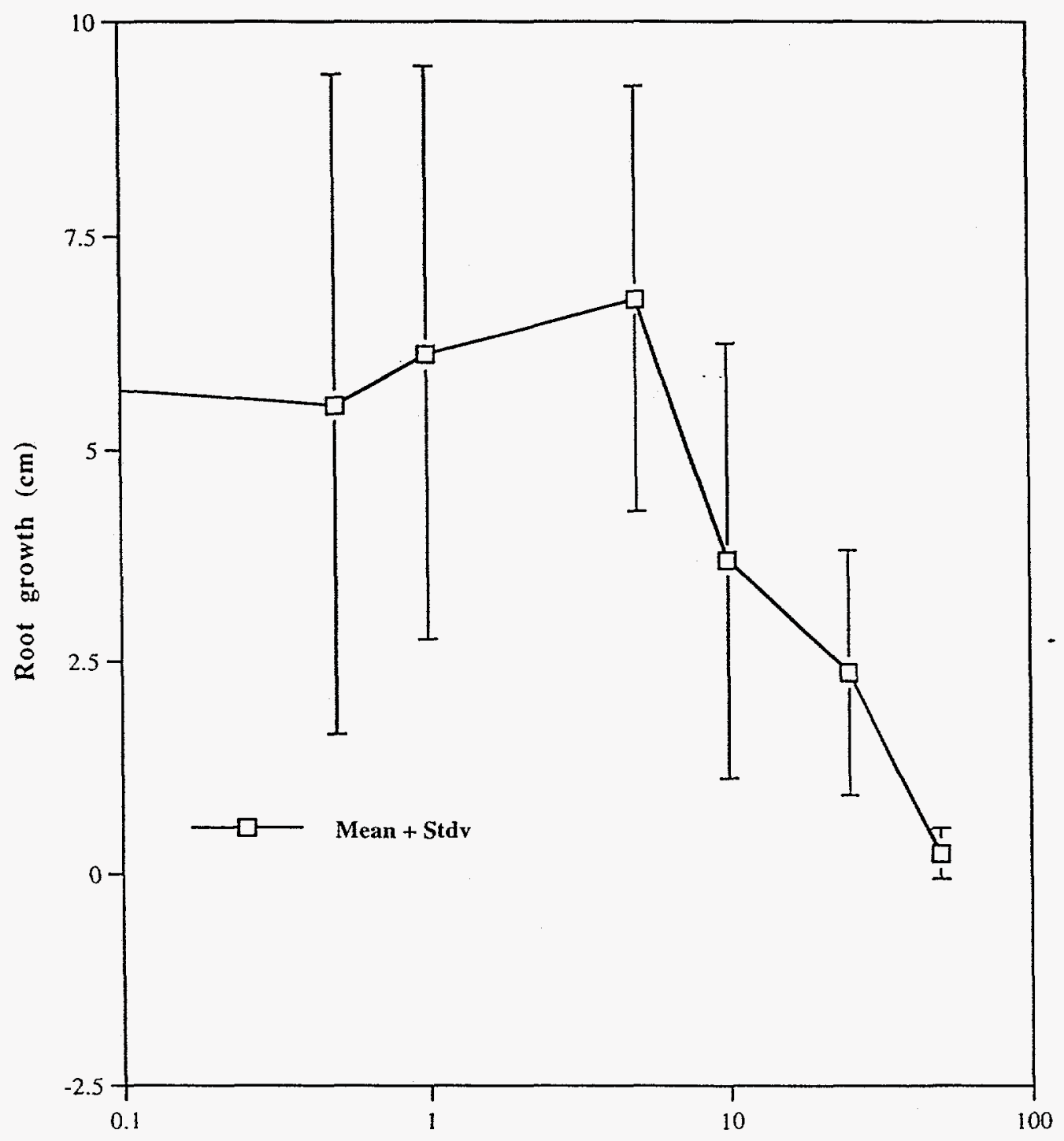

$\mathrm{Ni}(\mathbf{p p m})$ 
Figure 38.

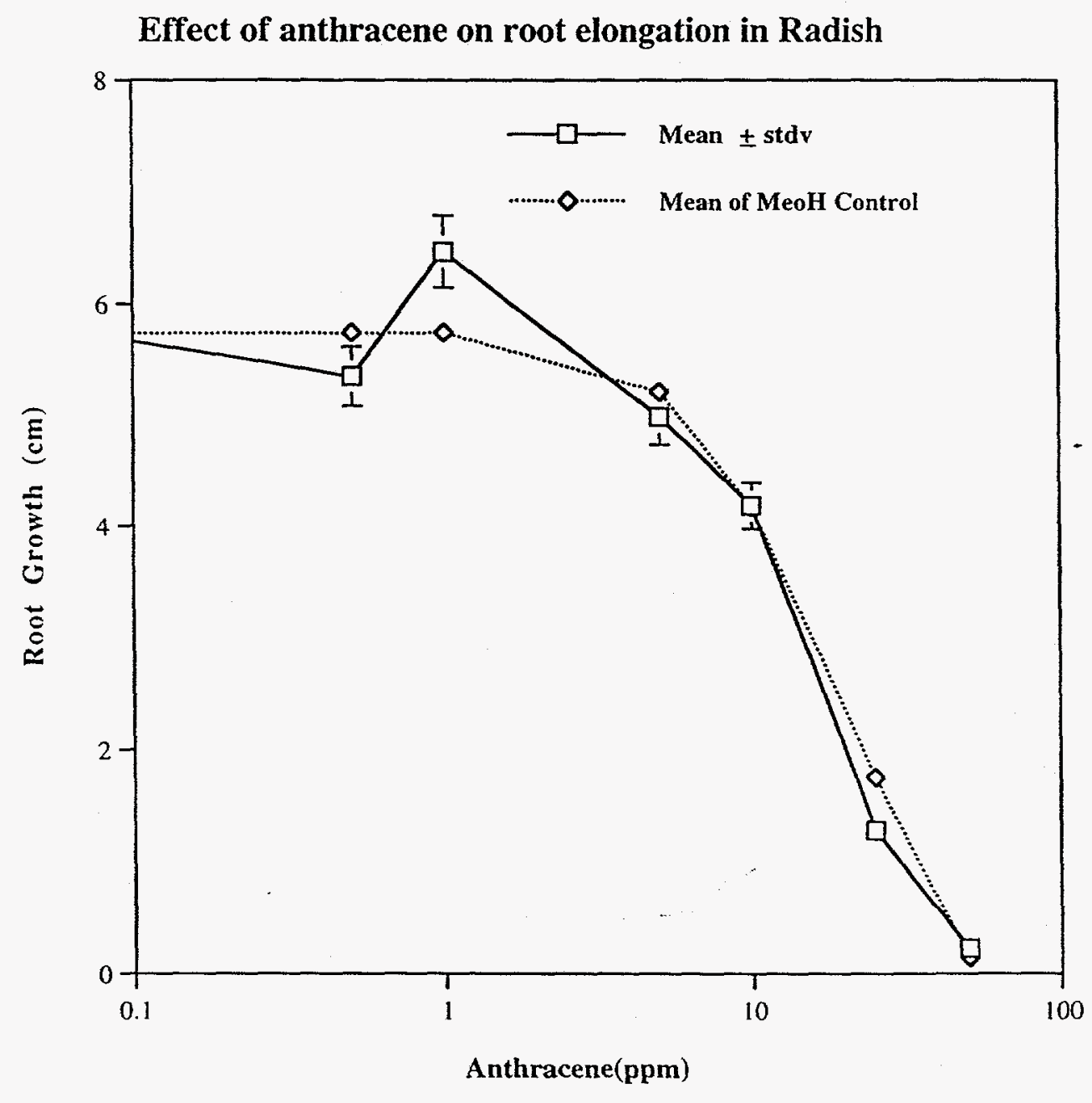


Figure 39.

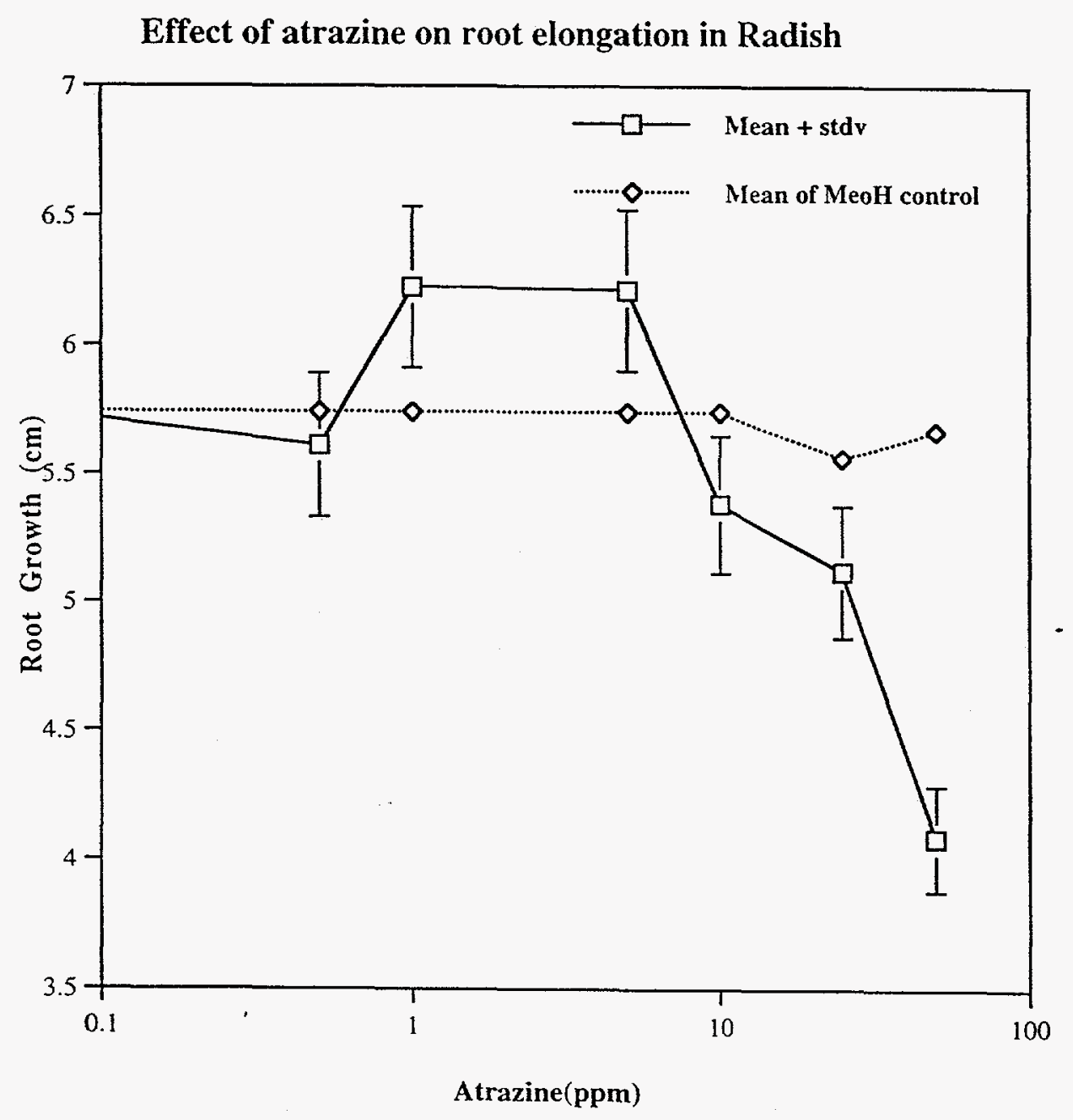


Figure 40.

Effect of tetrachloroethylene on root elongation in Radish

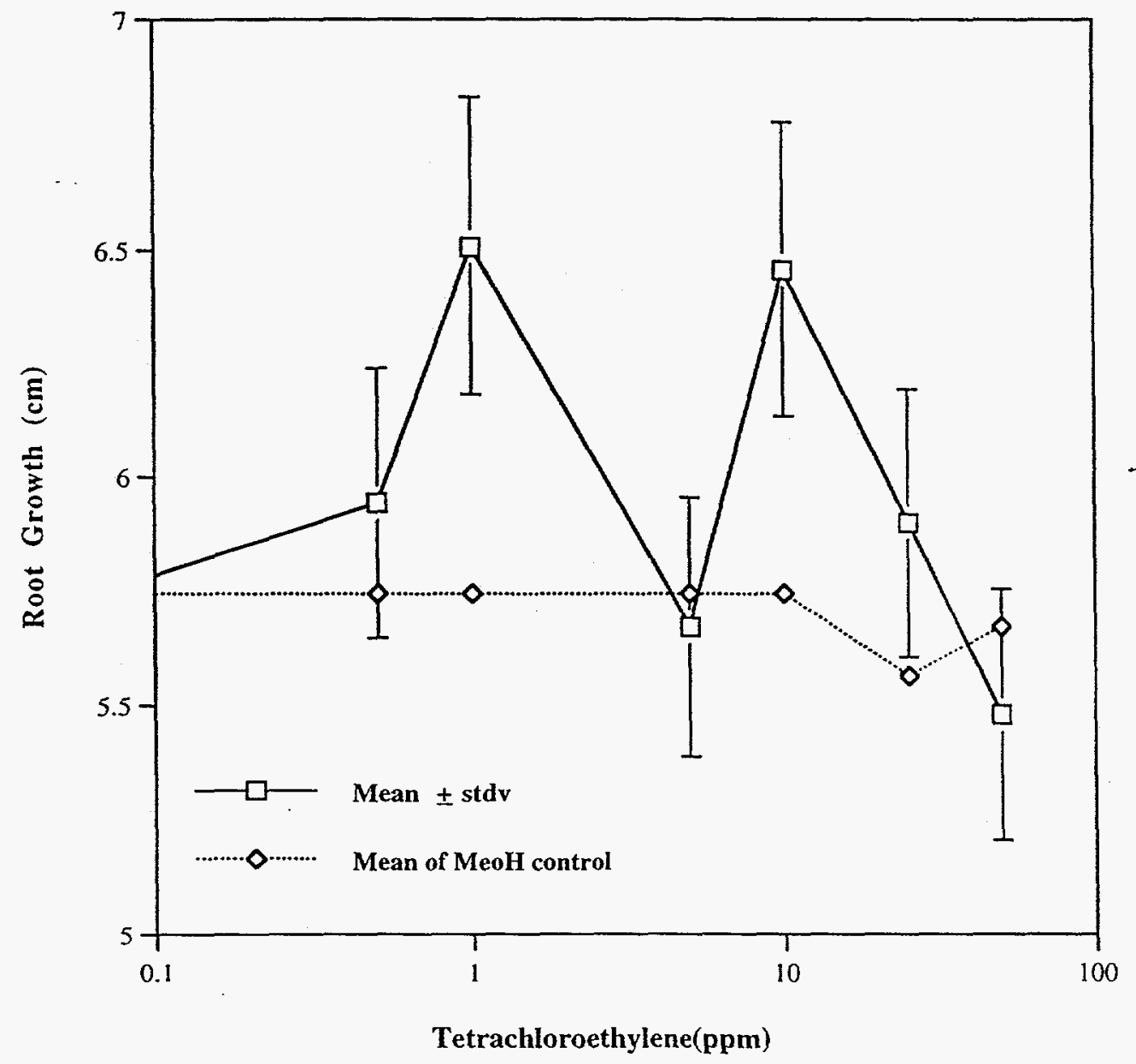


Figure 41.

Effect of cadmium on root elongation in Quercus falcata.

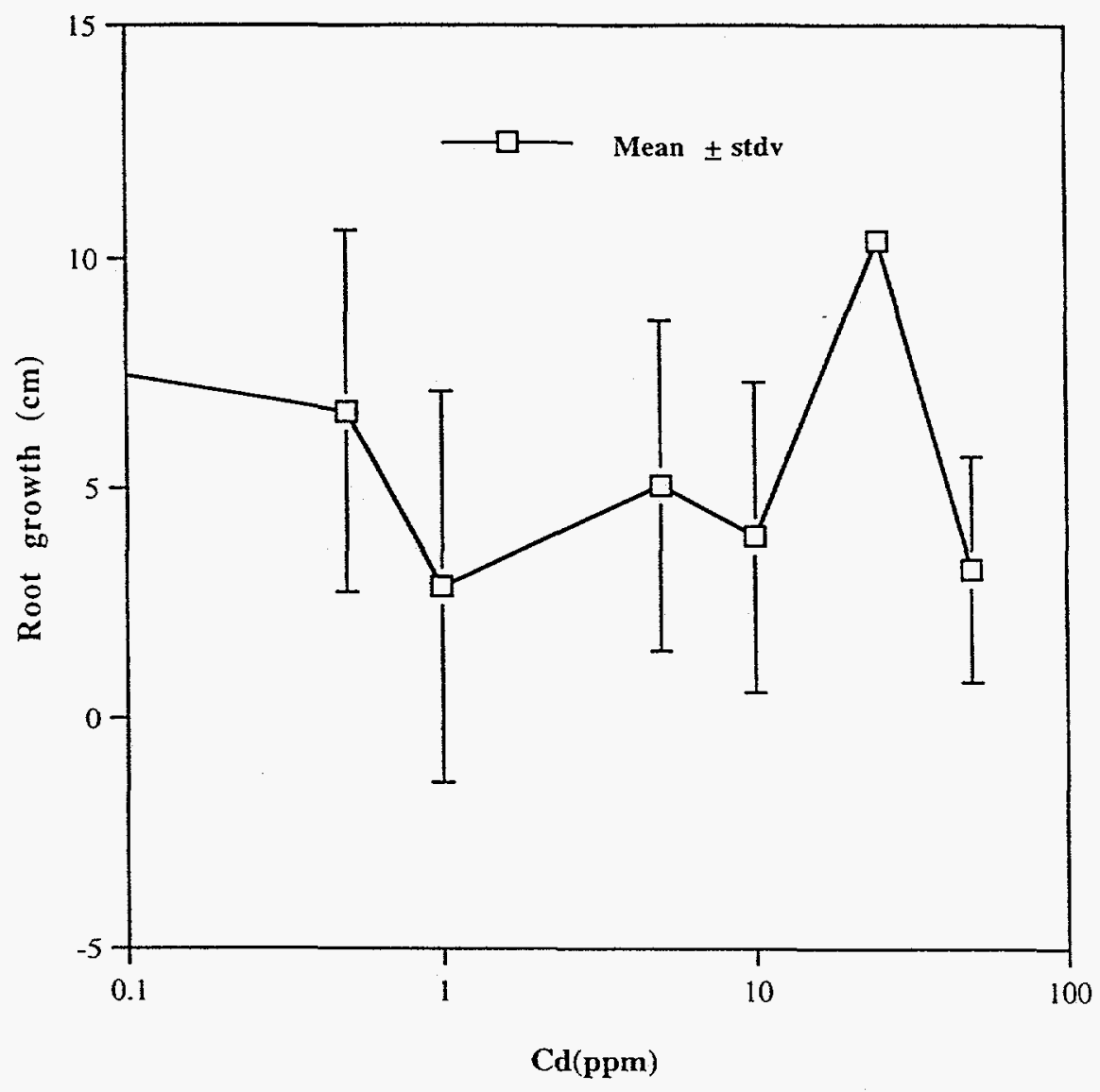


Figure 42.

Effect of nickel on root elongation in Quercus falcata.

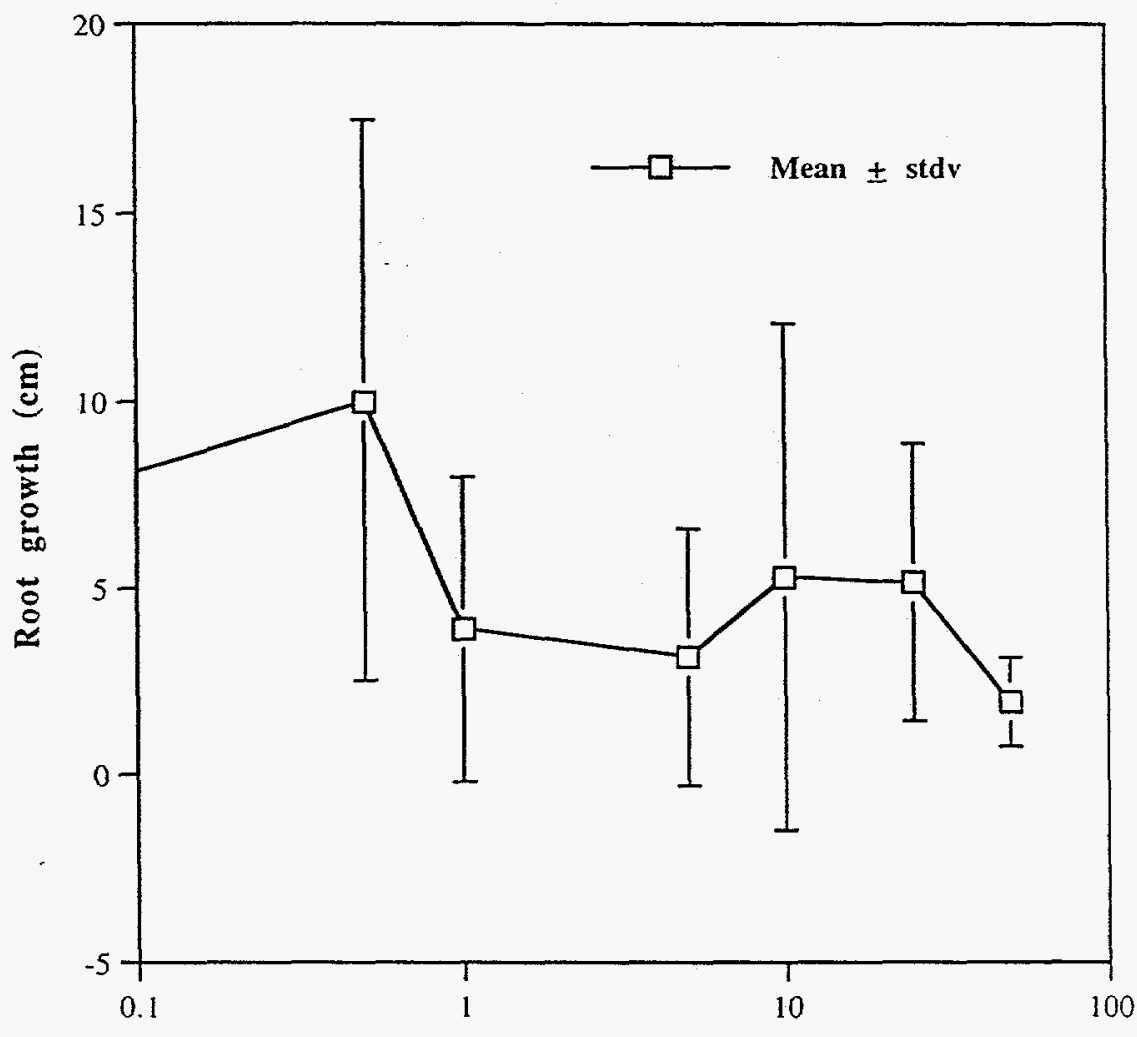

$\mathrm{Ni}(\mathrm{ppm})$ 
Figure 43.

Effect of anthracene on root elongation in Quercus falcata.

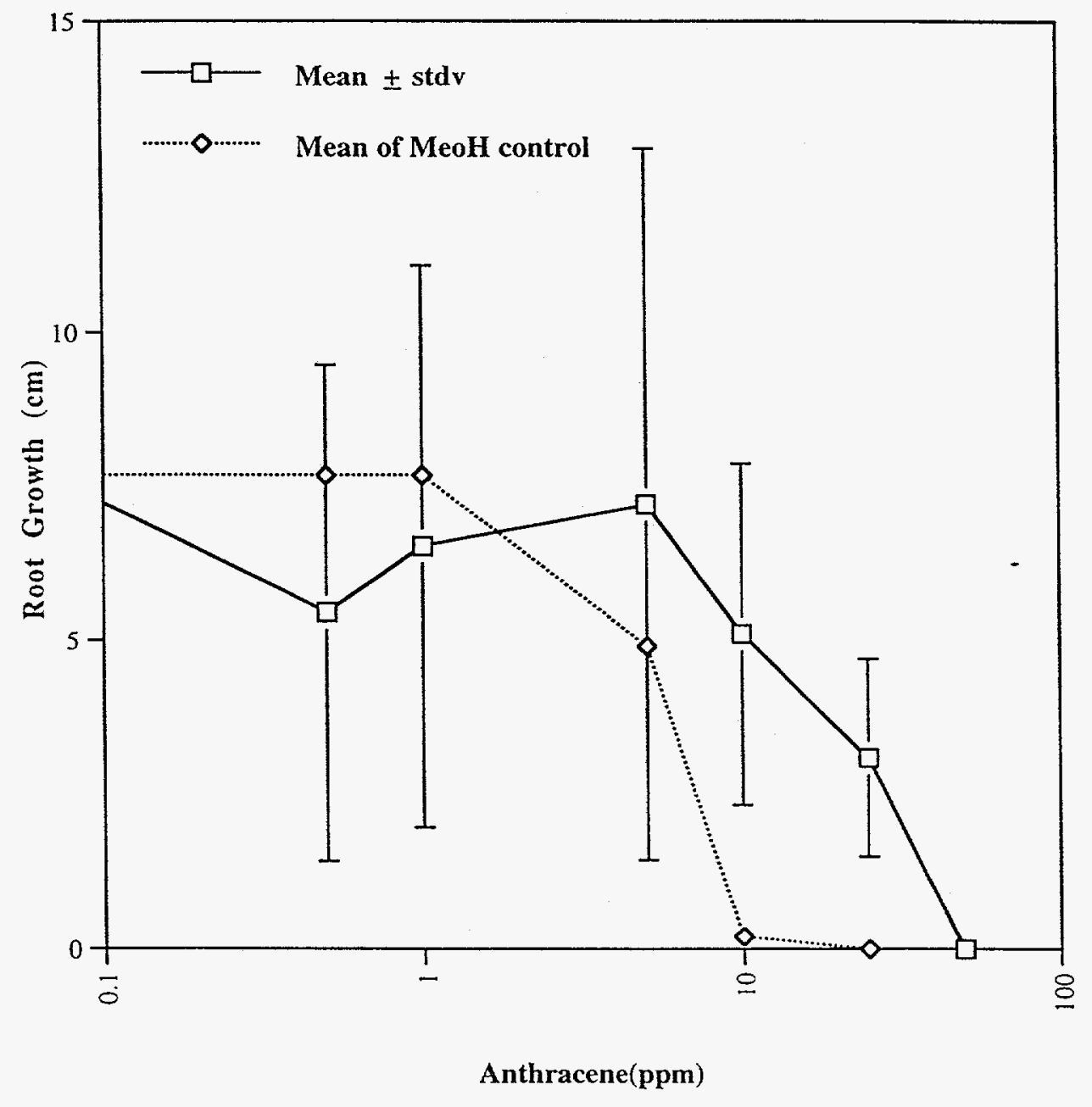


Figure 44.

Éffect of atrazine on root elongation in Quercus falcata.

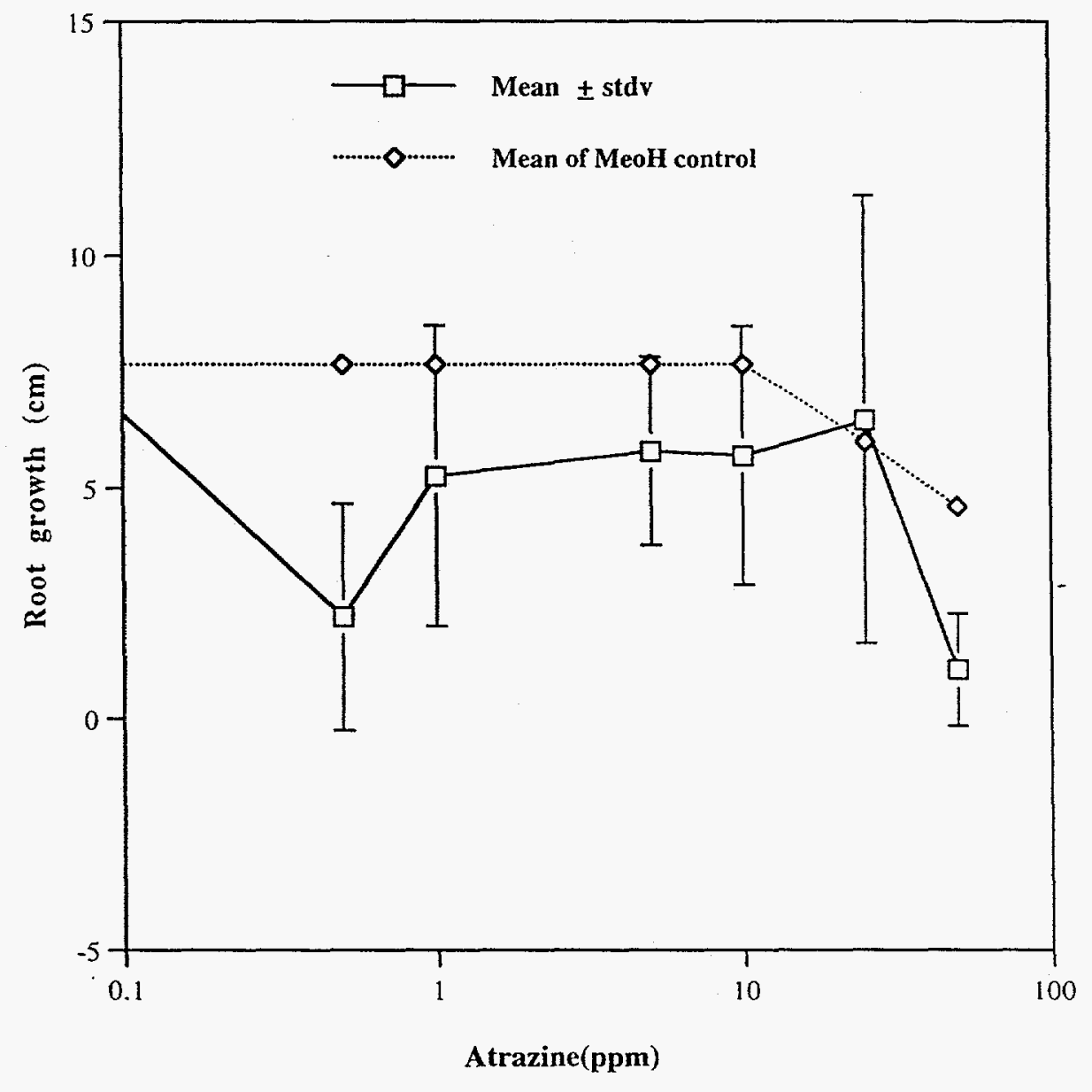


Figure 45.

Effect of tetrachloroethylene on root elongation in Quercus falcata.

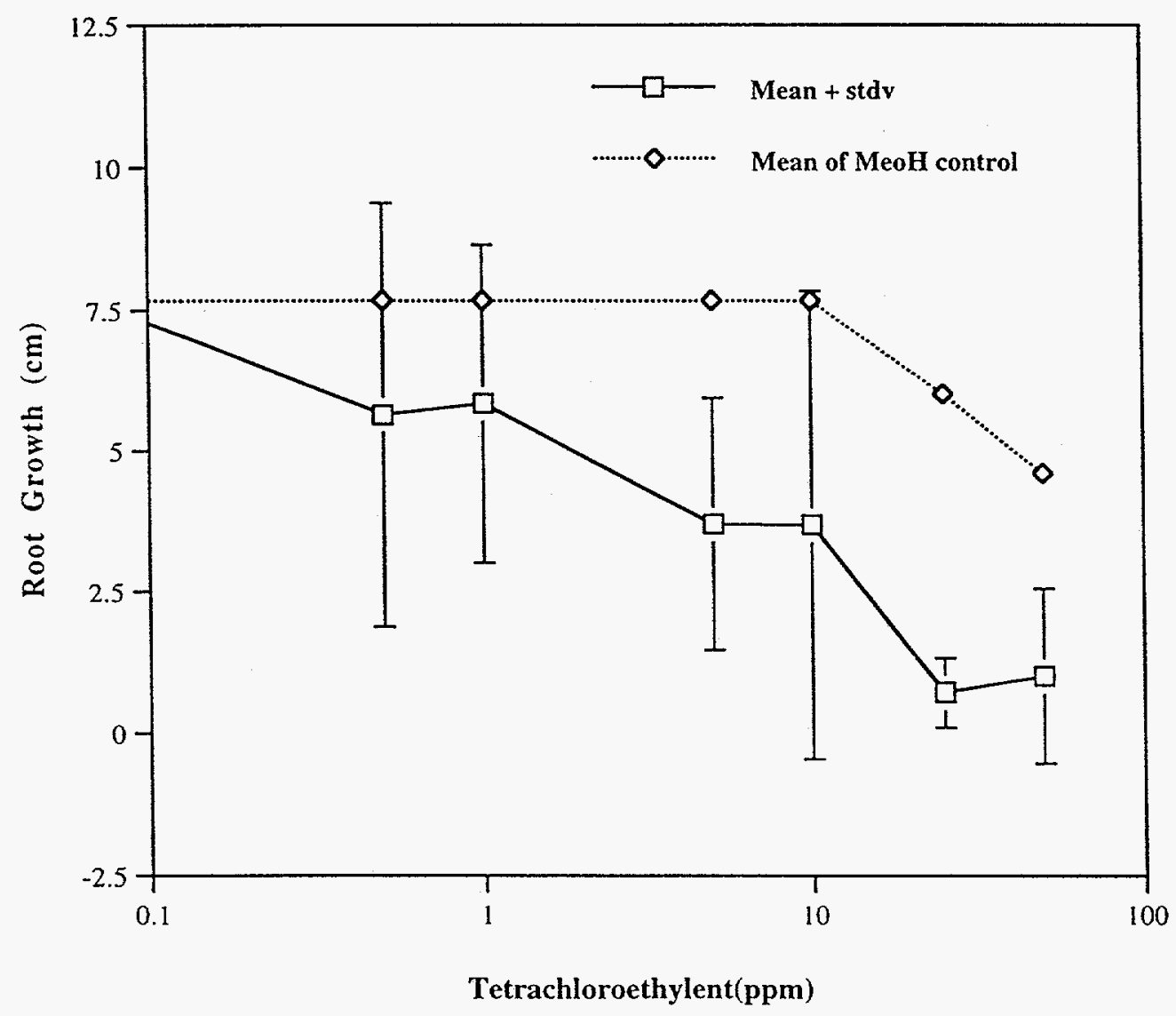


Figure 46.

Impact of Cd on root elongation in Lactuca sativa

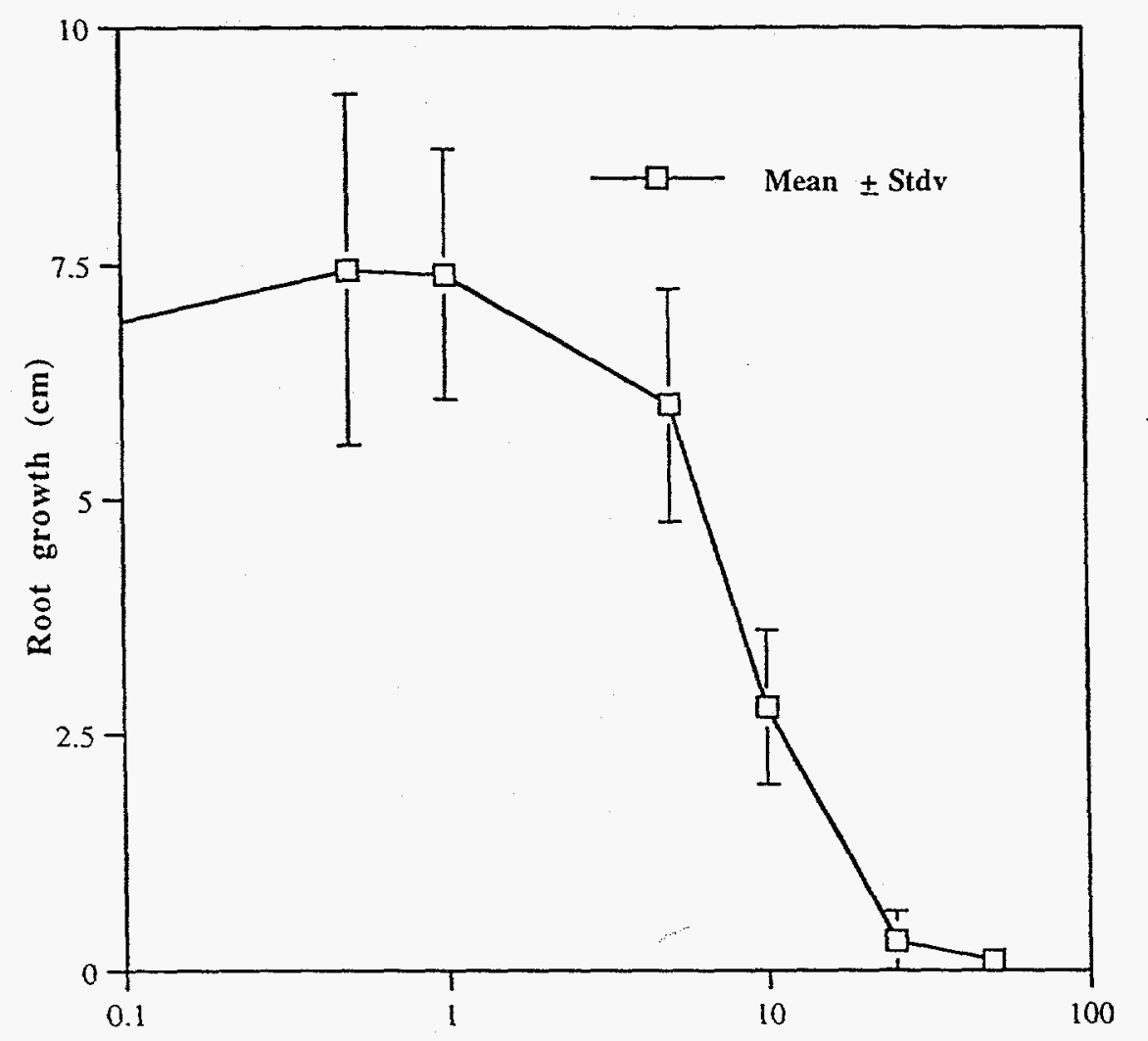

Cd(ppm) 
Figure 47.

Impact of Ni on root elongation in Lactuca sativa

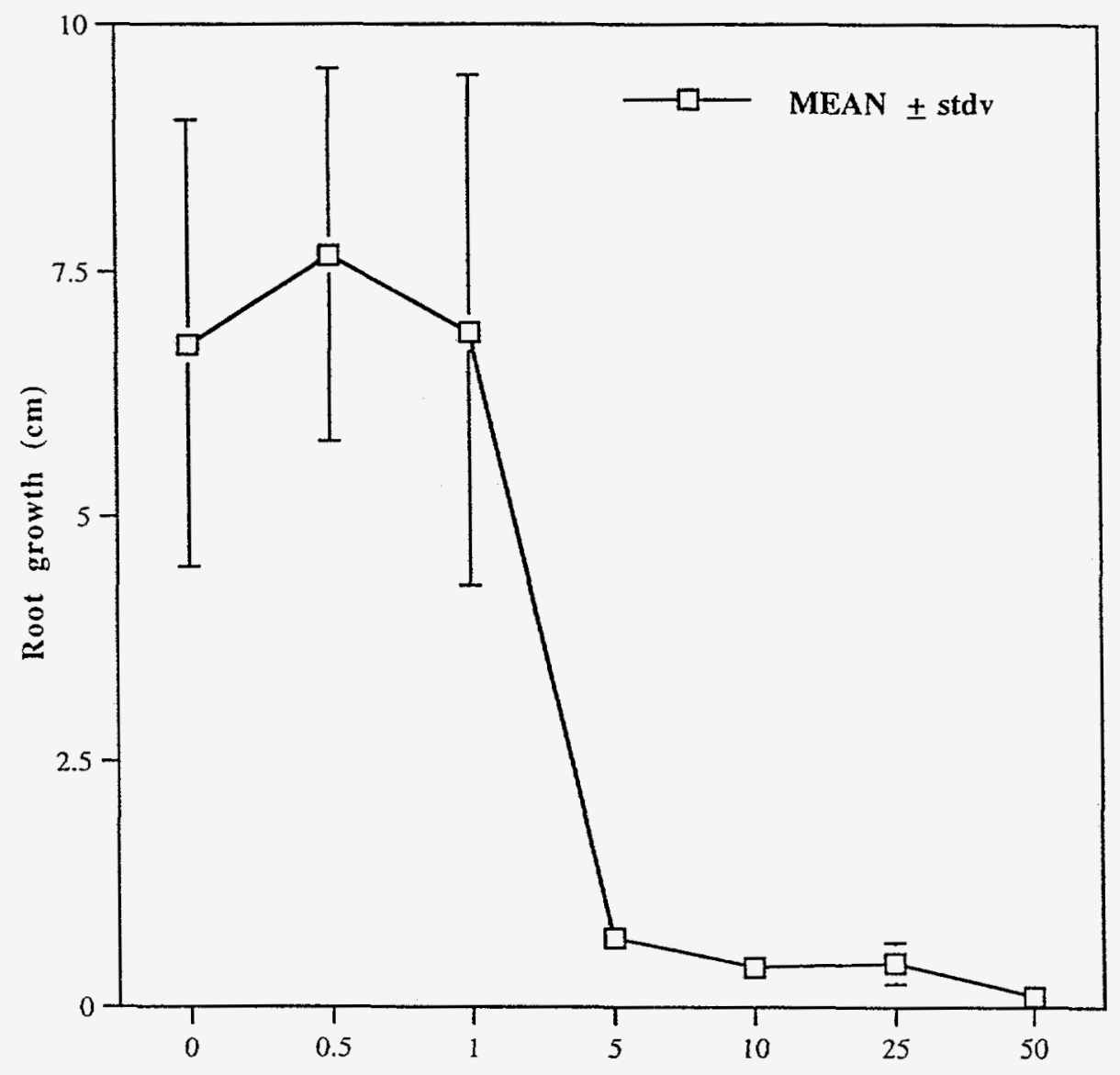

Ni(ppm) 
Figure 48 .

Effect of anthracene on the root elongation of Lactuca sativa

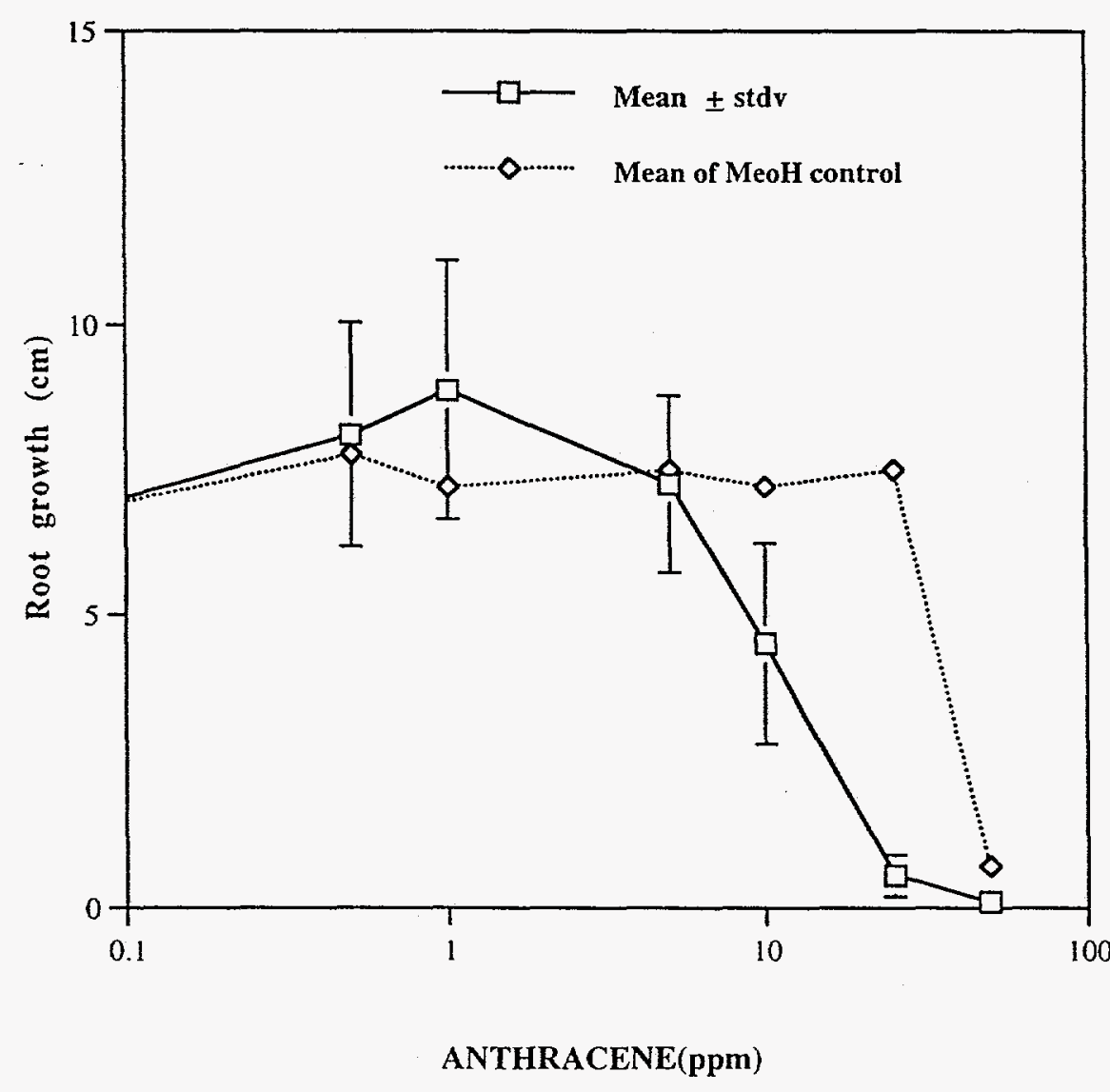


Figure 49.

Effect of atrazine on root elongation in Lactuca sativa

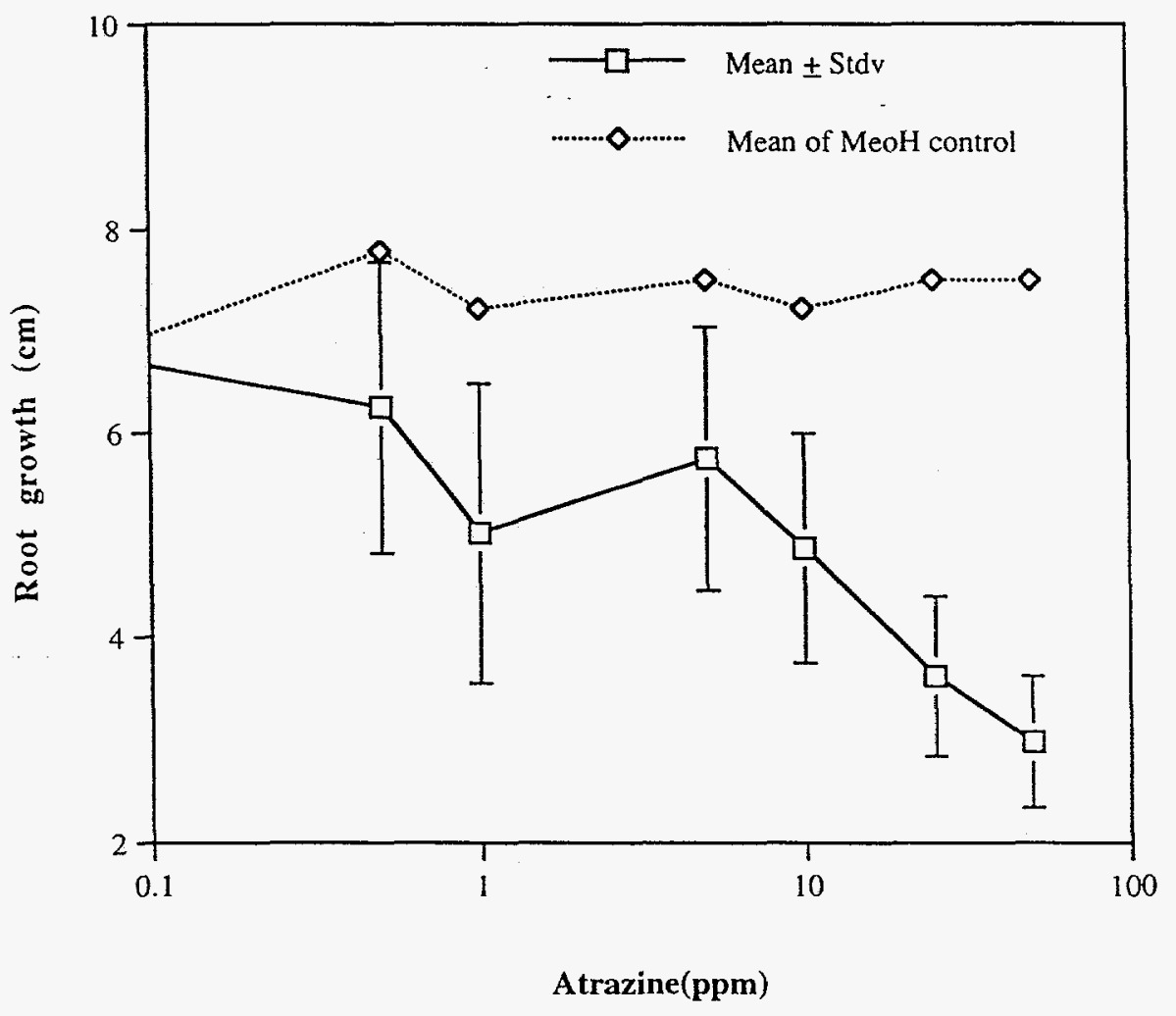


Figure 50.

Effect of Tetrachloroethylene on root elongation in Lactuca sativa

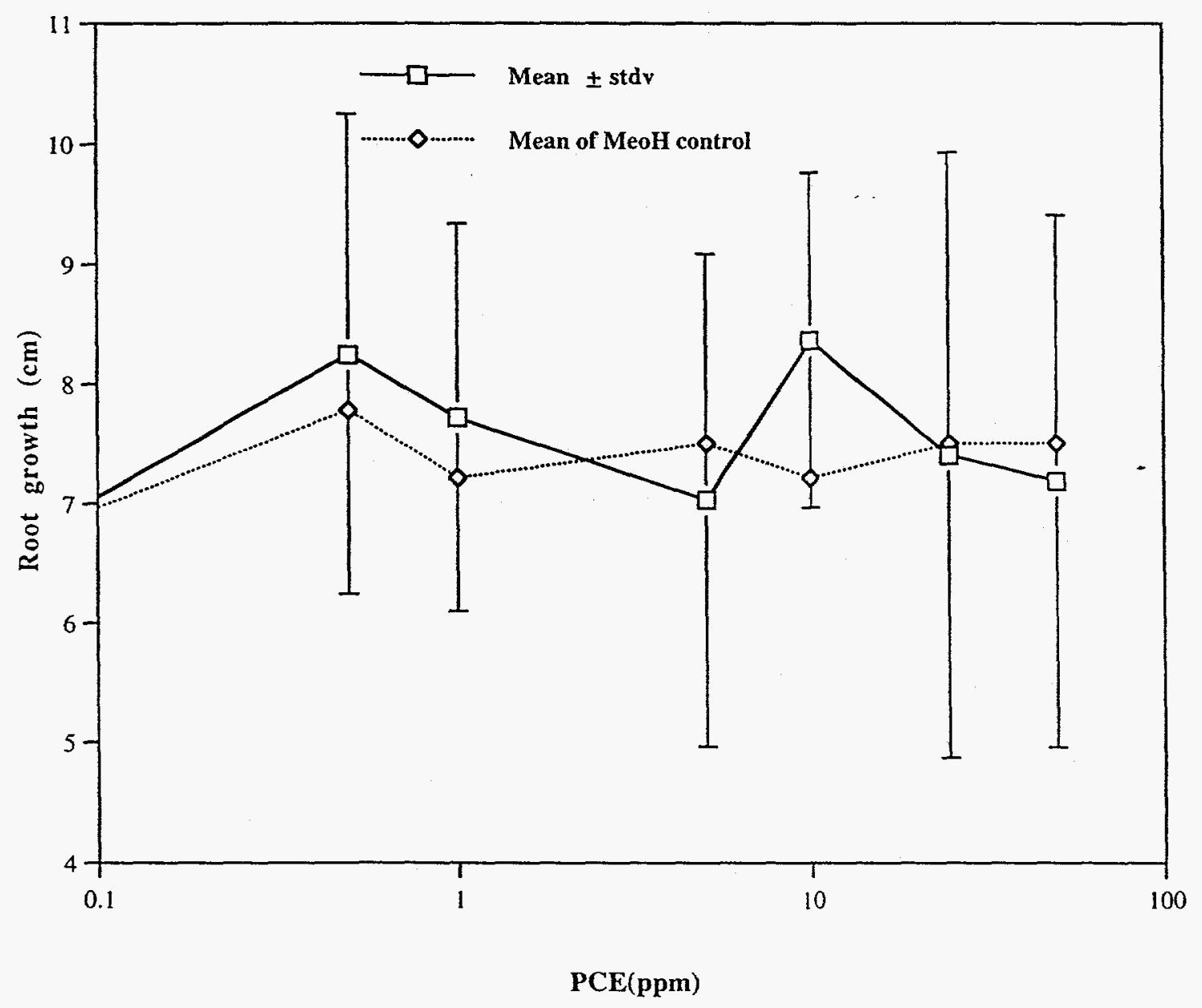




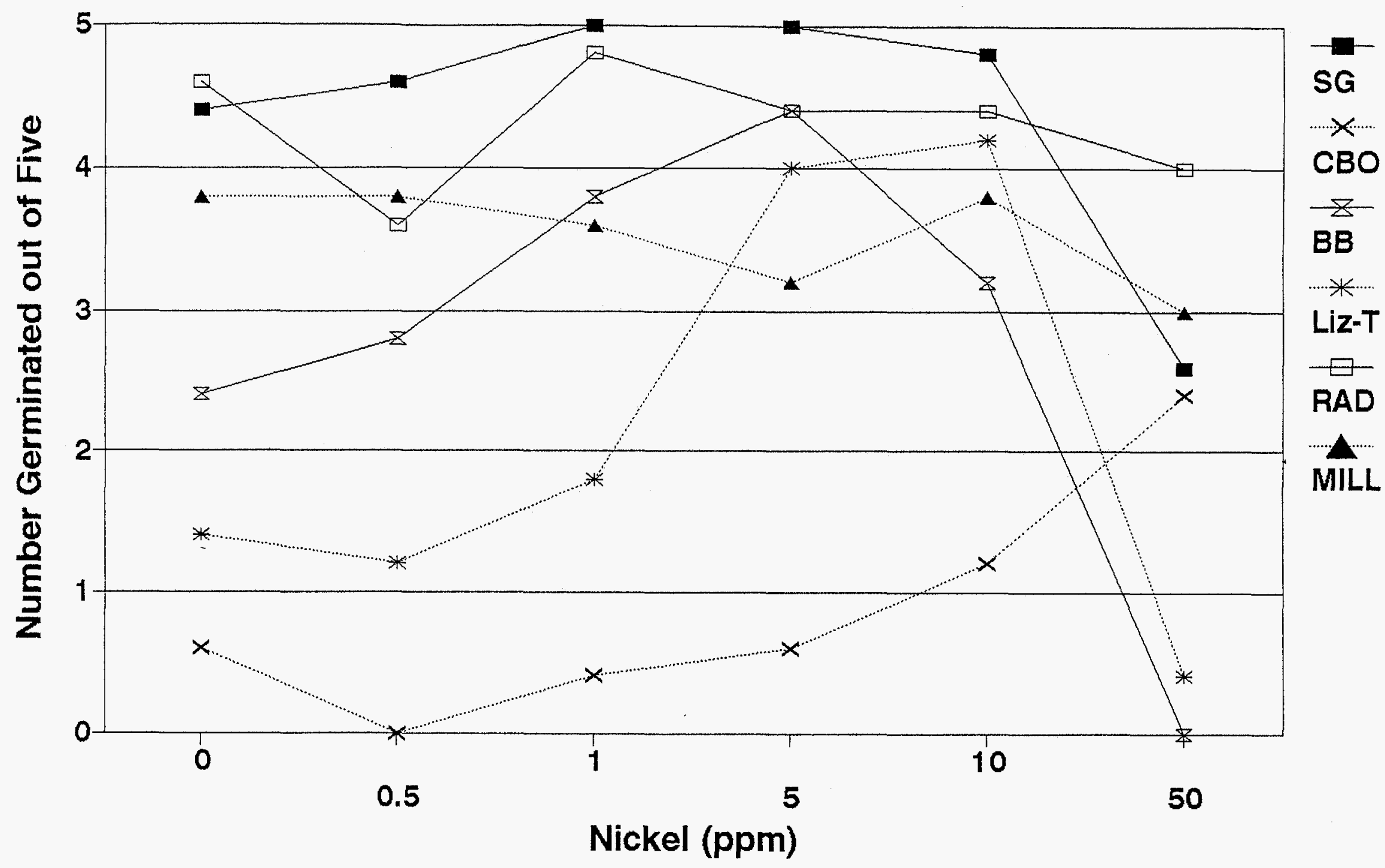

Figure 51. Number of seed out of five that germinated by dose rate for six species. $S G=$ sweetgum, $C B O=$ cherrybark oak, $B B=$ buttonbush, Liz-T = lizard's tail, RAD $=$ radish, MILL $=$ millet 


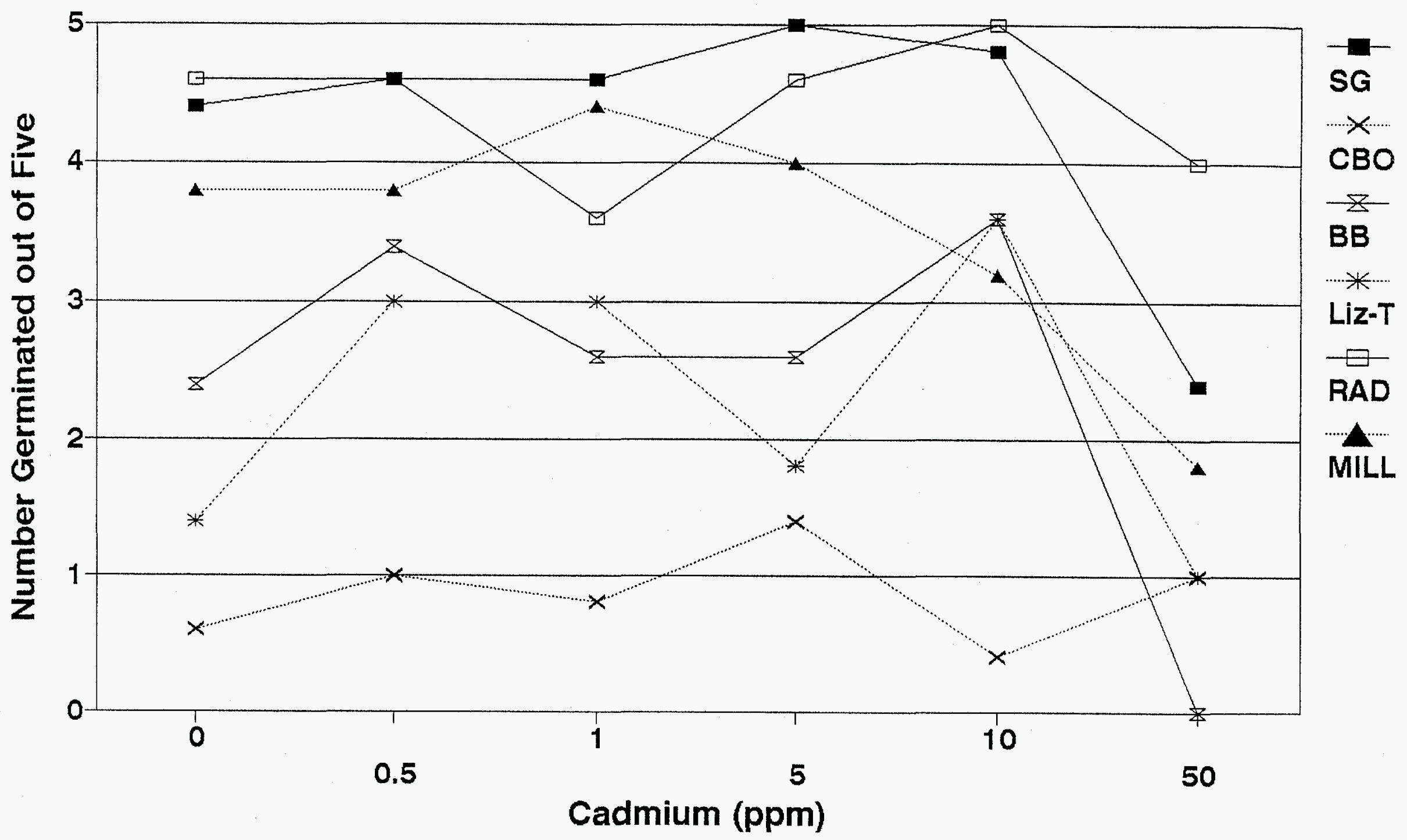

Figure 52. Number of seed that germinated out of five by dose rate for six species. $S G=$ sweetgum, $C B O=$ cherrybark oak, $B B=$ buttonbush, $L i z=T=$ lizard's tail, MILL = millet. 


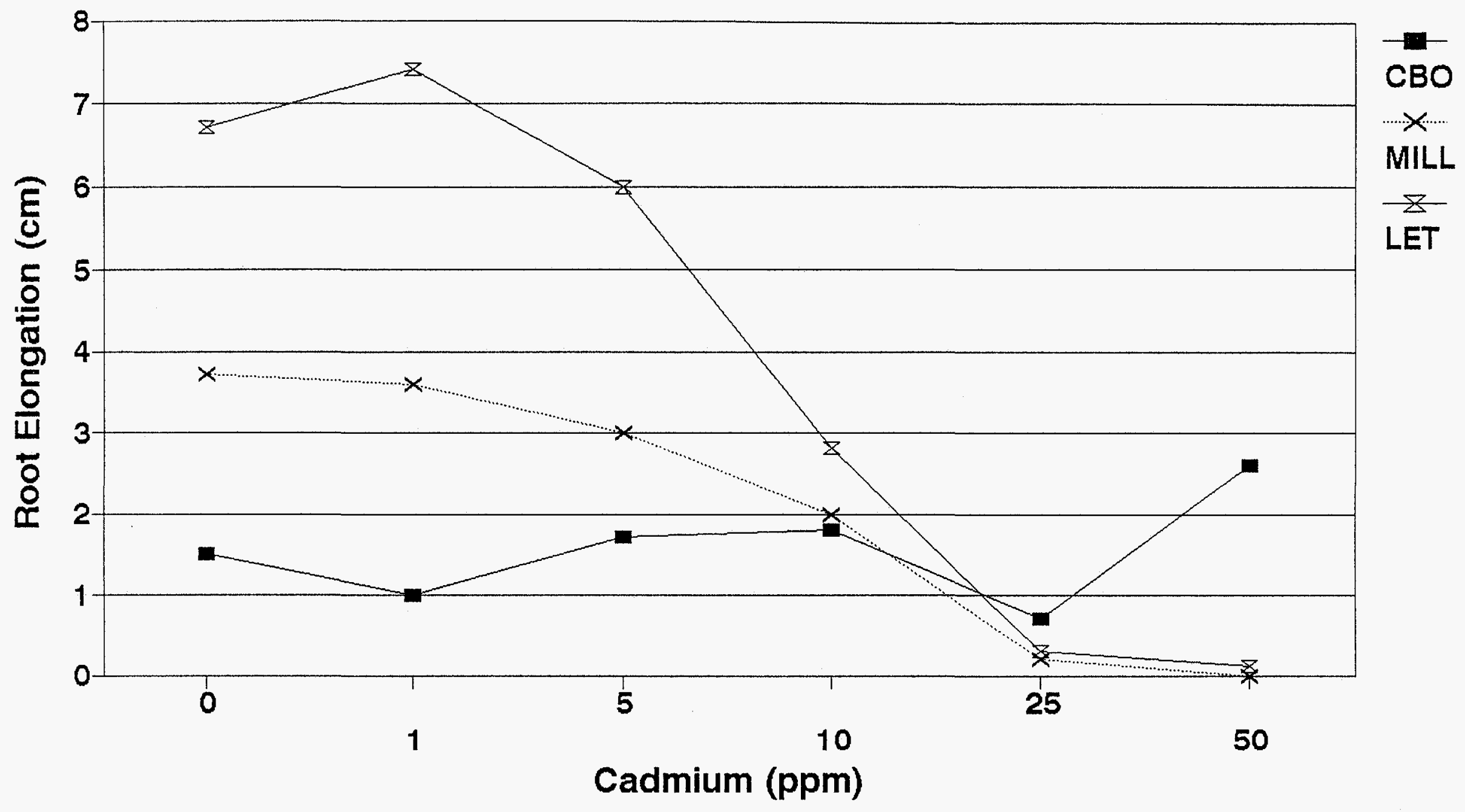

Figure 53. Root elongation in relation to dose rate for three species. $\mathrm{CBO}=$ cherrybark oak, MILL = millet, LET = lettuce 


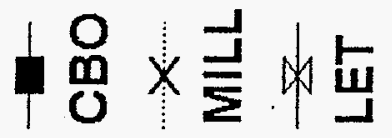

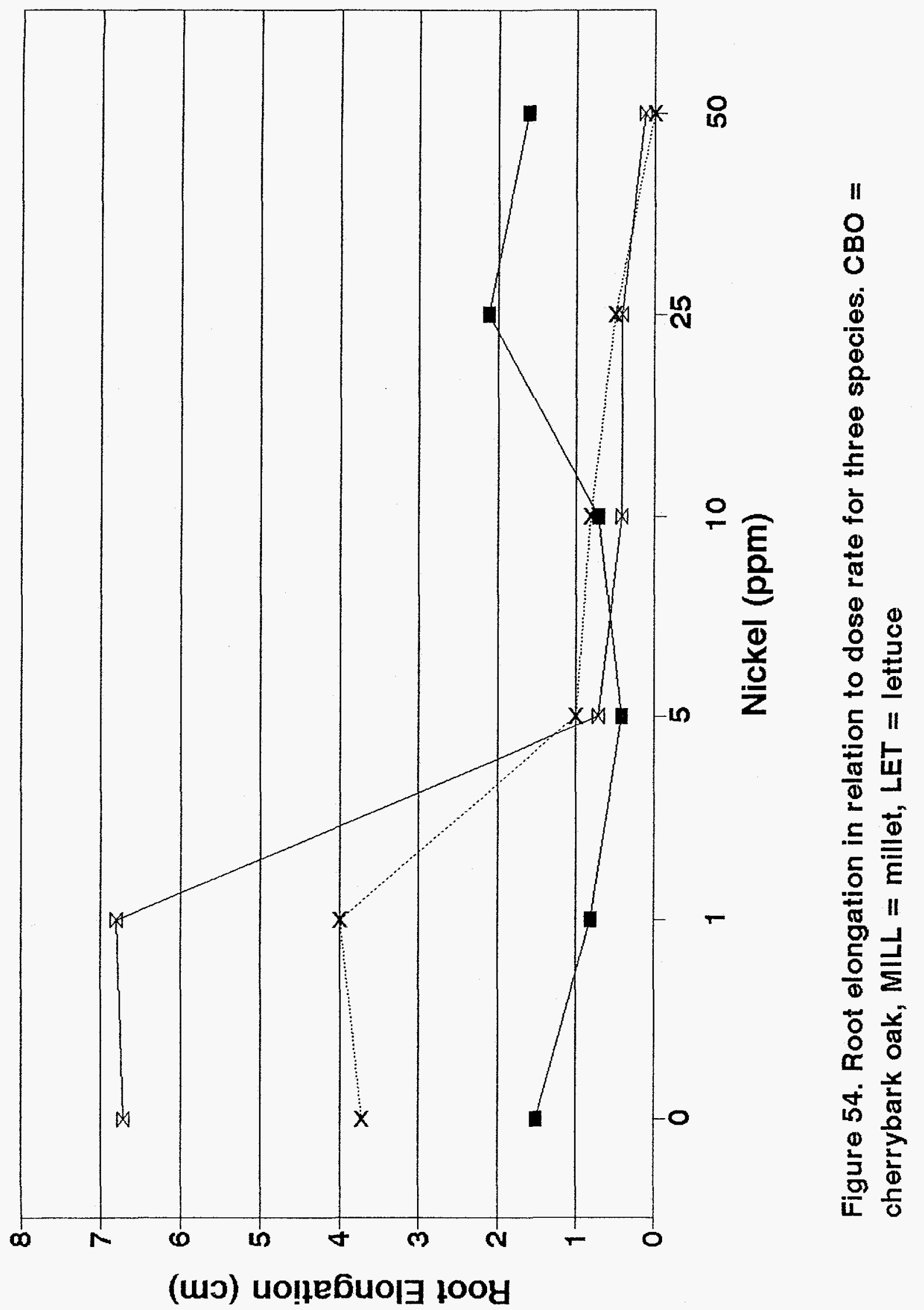




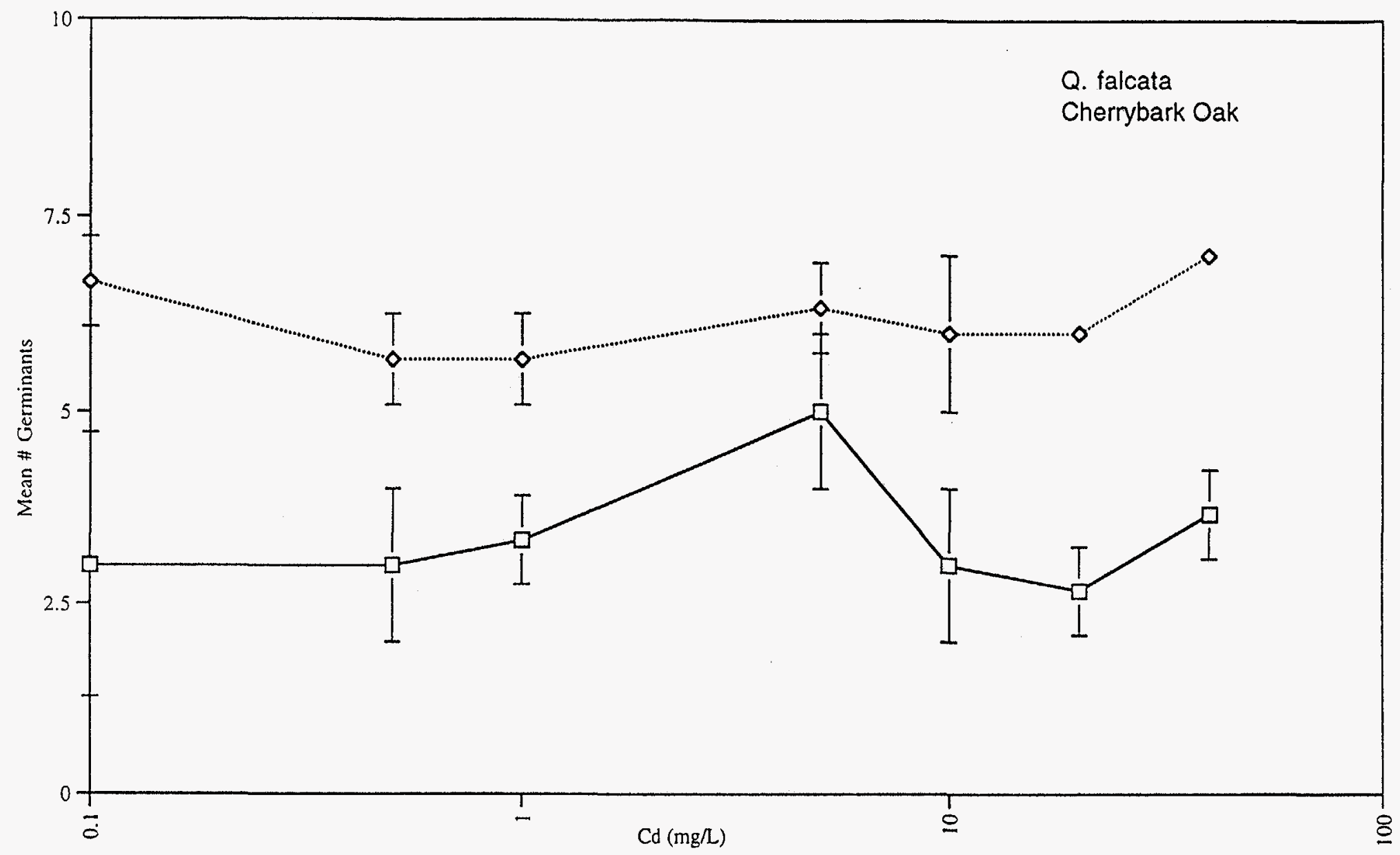

Figure 55. Influence of cadmium on seed germination in $Q$. falcata. Squares represent data taken on Day 5; diamonds represent data taken on Day 10. 


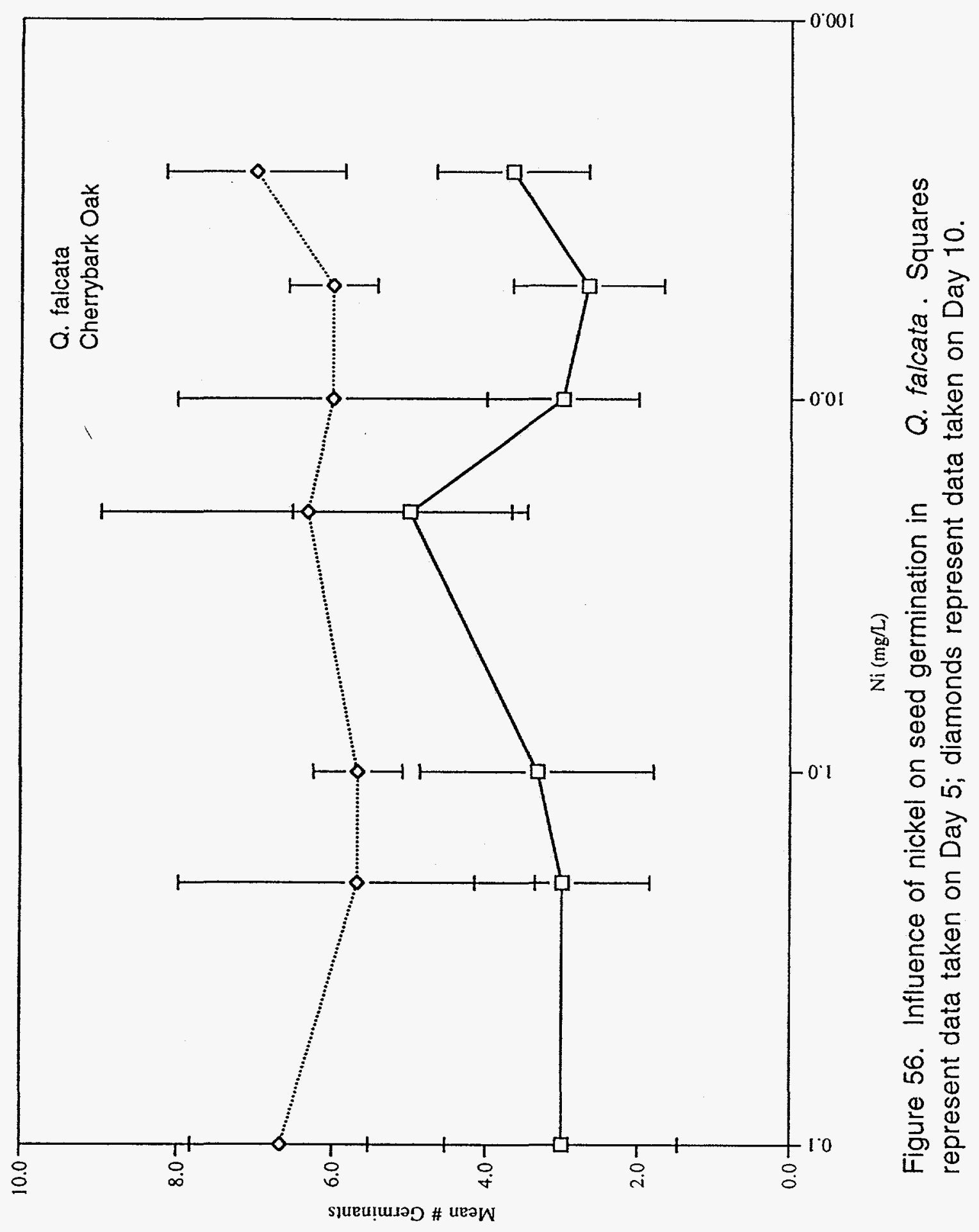




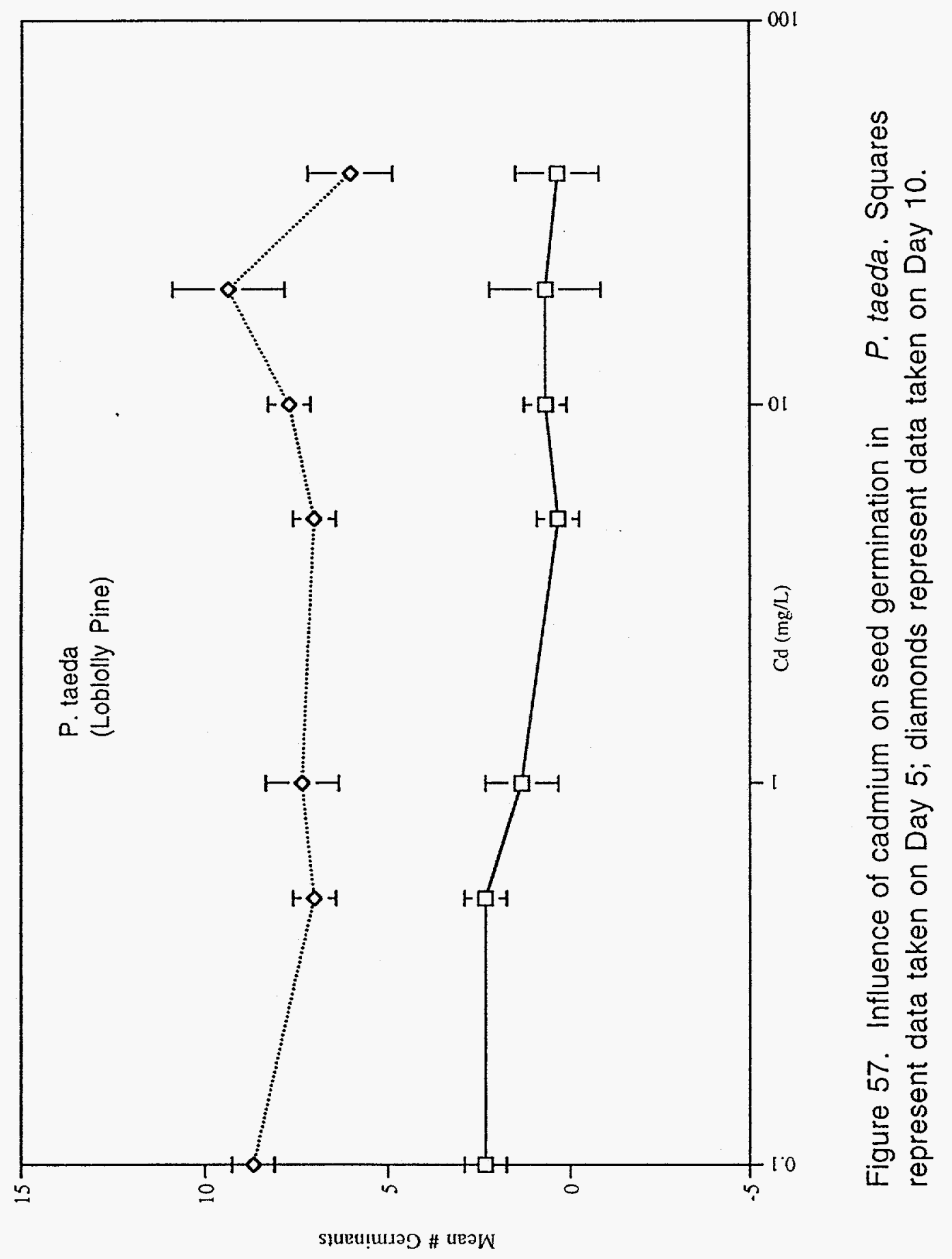




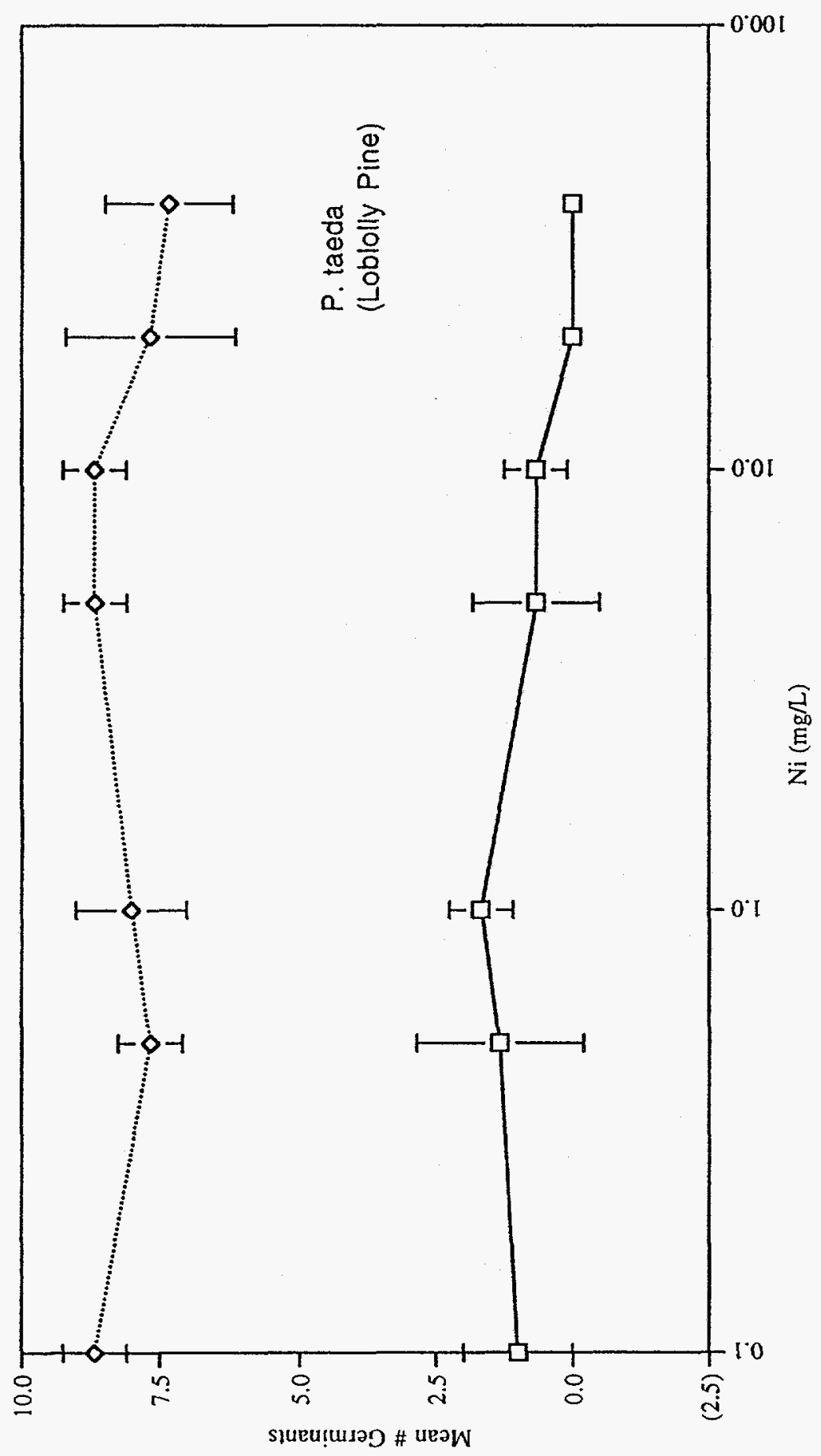

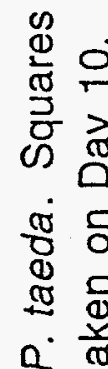

a

$\subseteq \stackrel{\frac{\pi}{\sigma}}{0}$

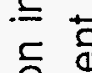

읋

$\frac{\substack{\text { Do } \\ \text { E }}}{\bar{z}}$

E

㐫 음

응

额

ㄷํ

文

.

45

엉 등

동

垔

ம

Ф

는 은 


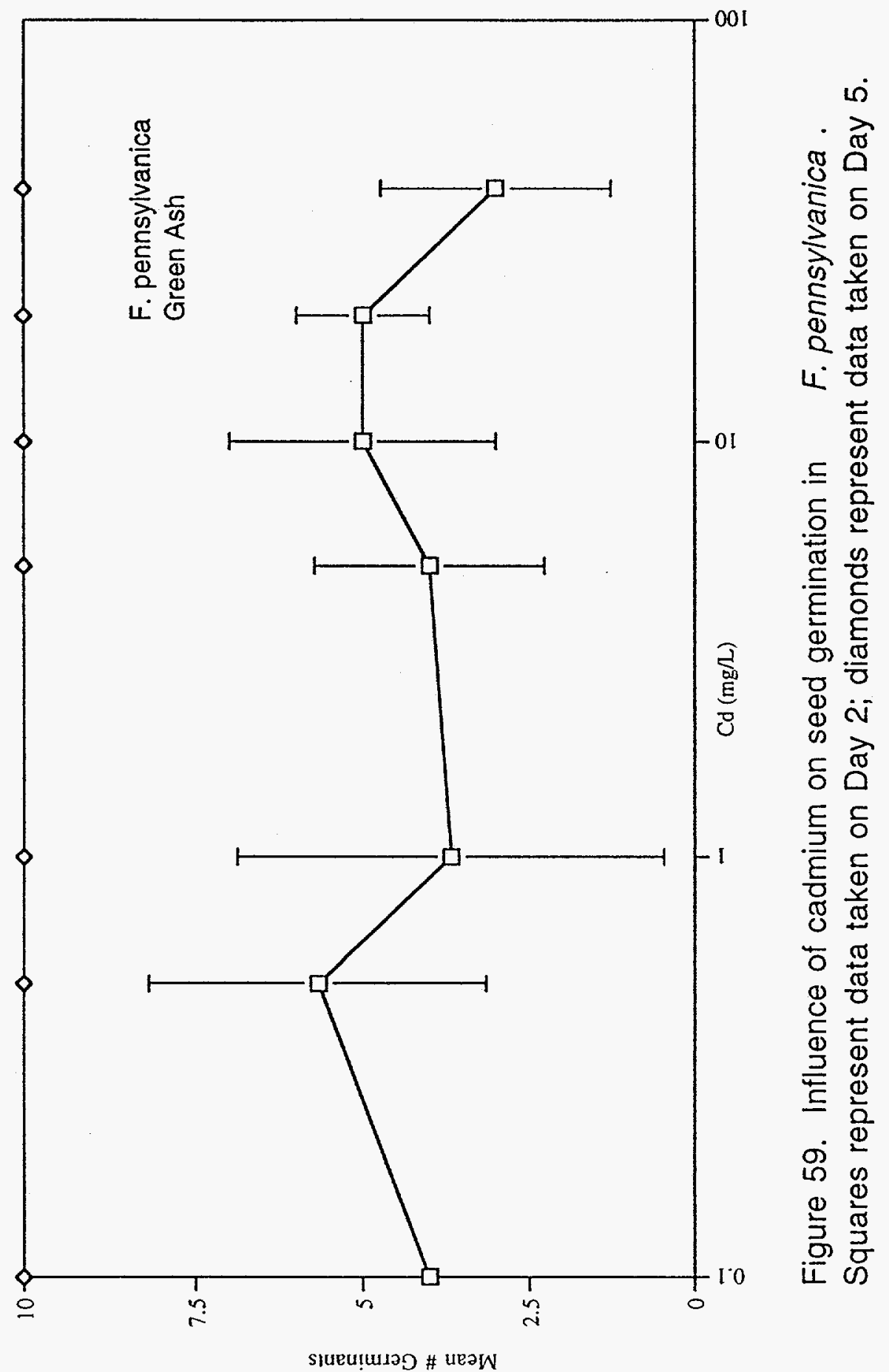




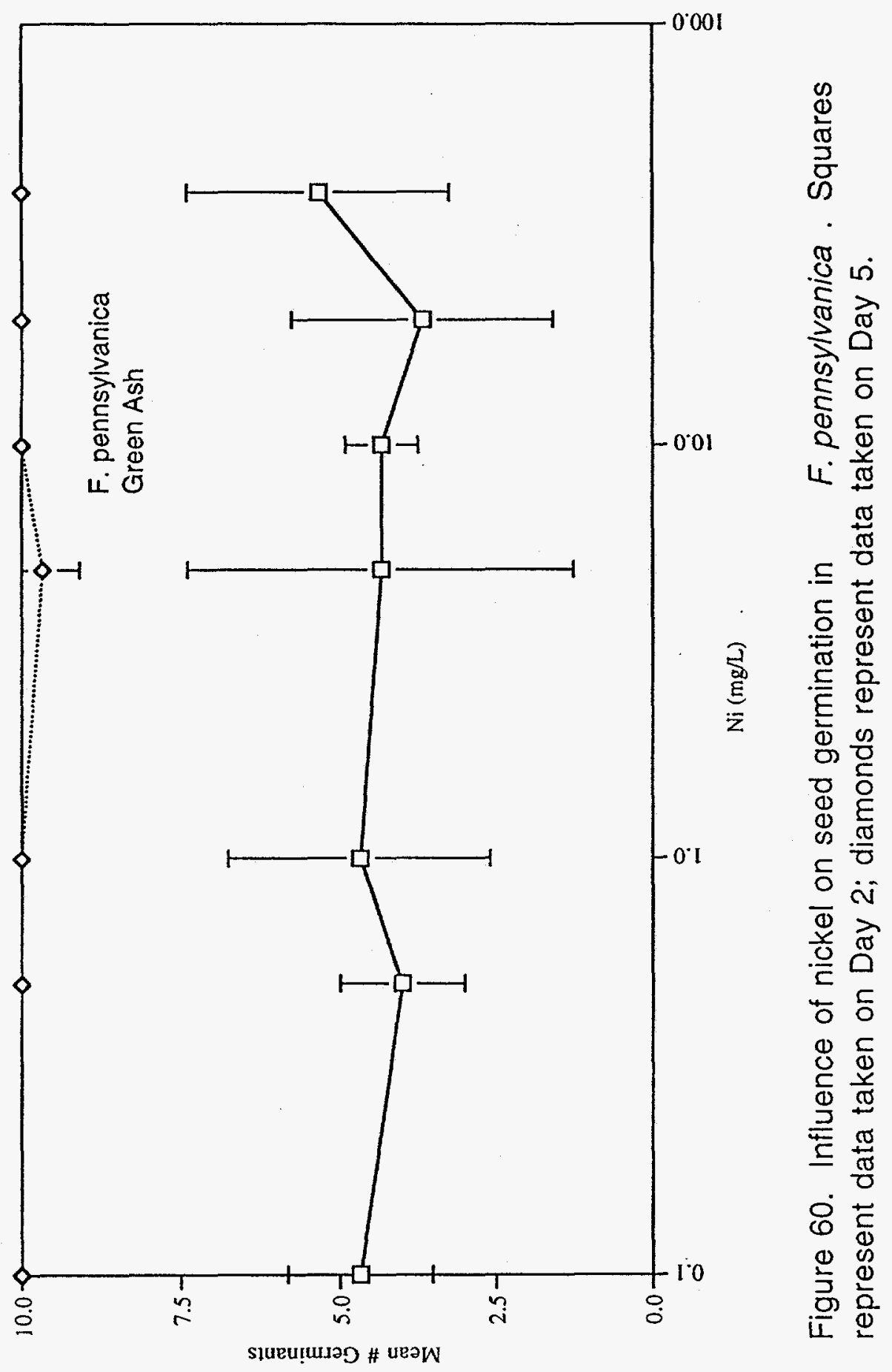




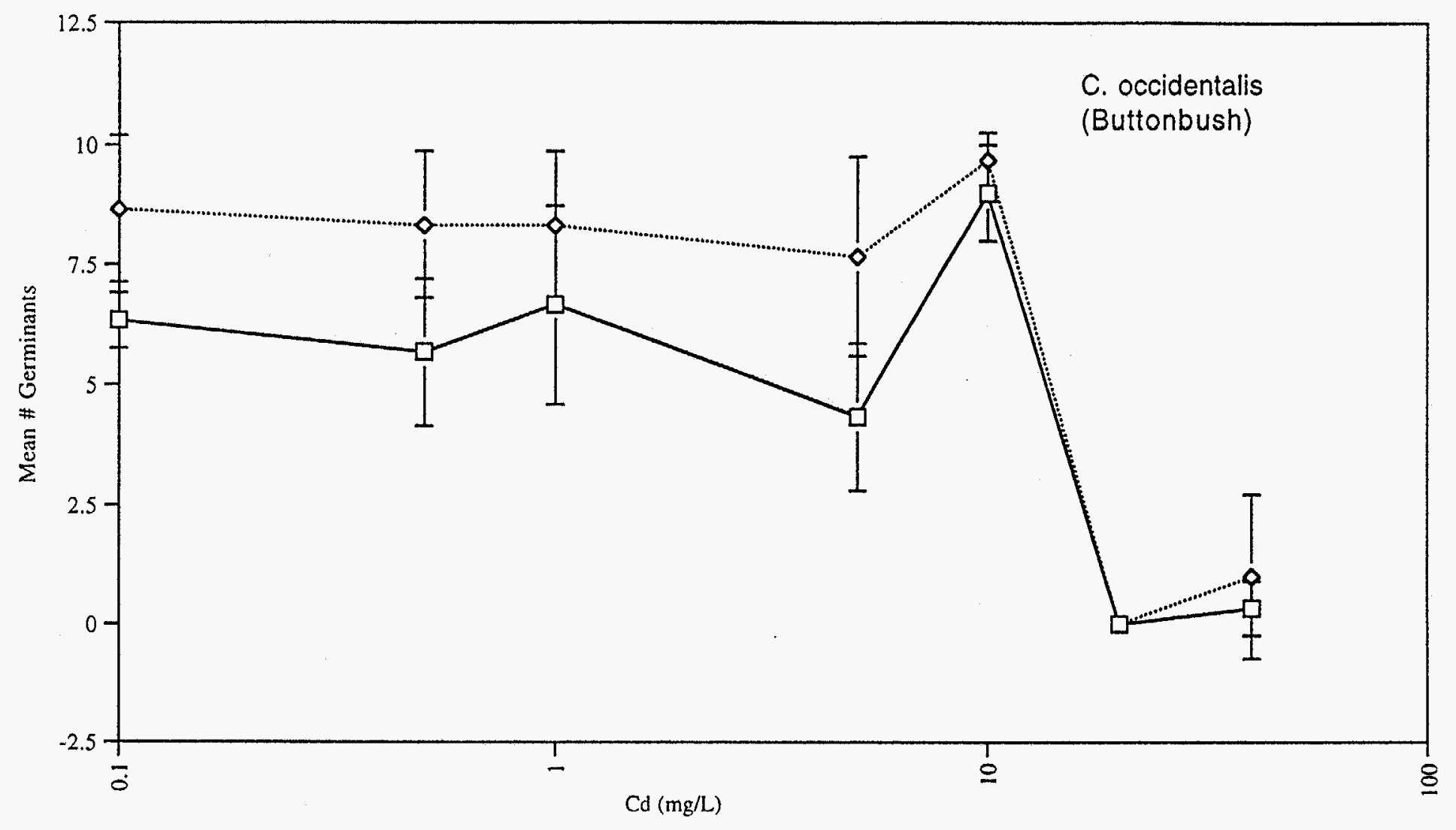

Figure 61. Influence of cadmium on seed germination in C. occidentalis . Squares represent data taken on Day 8; diamonds represent data taken on Day 10. 


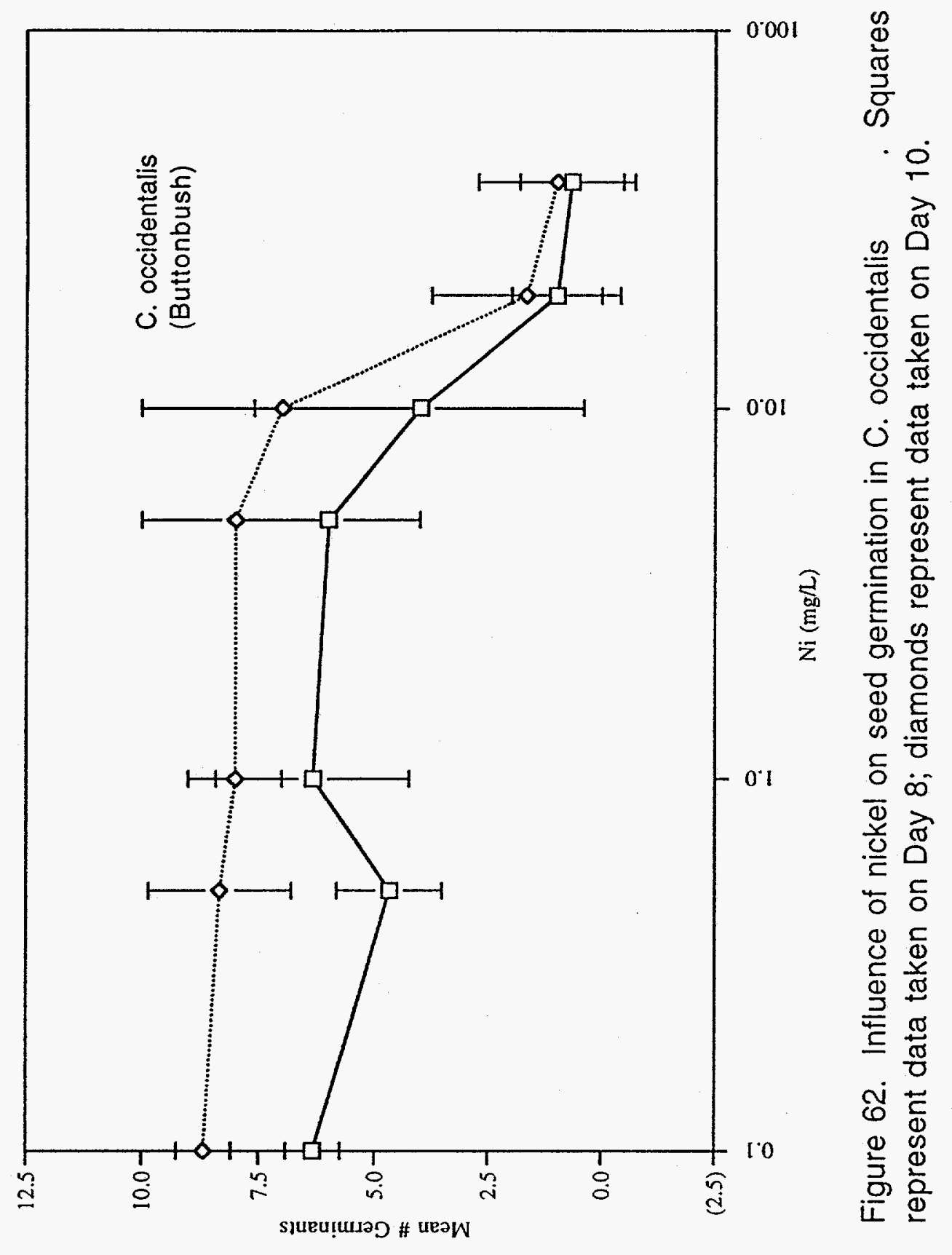




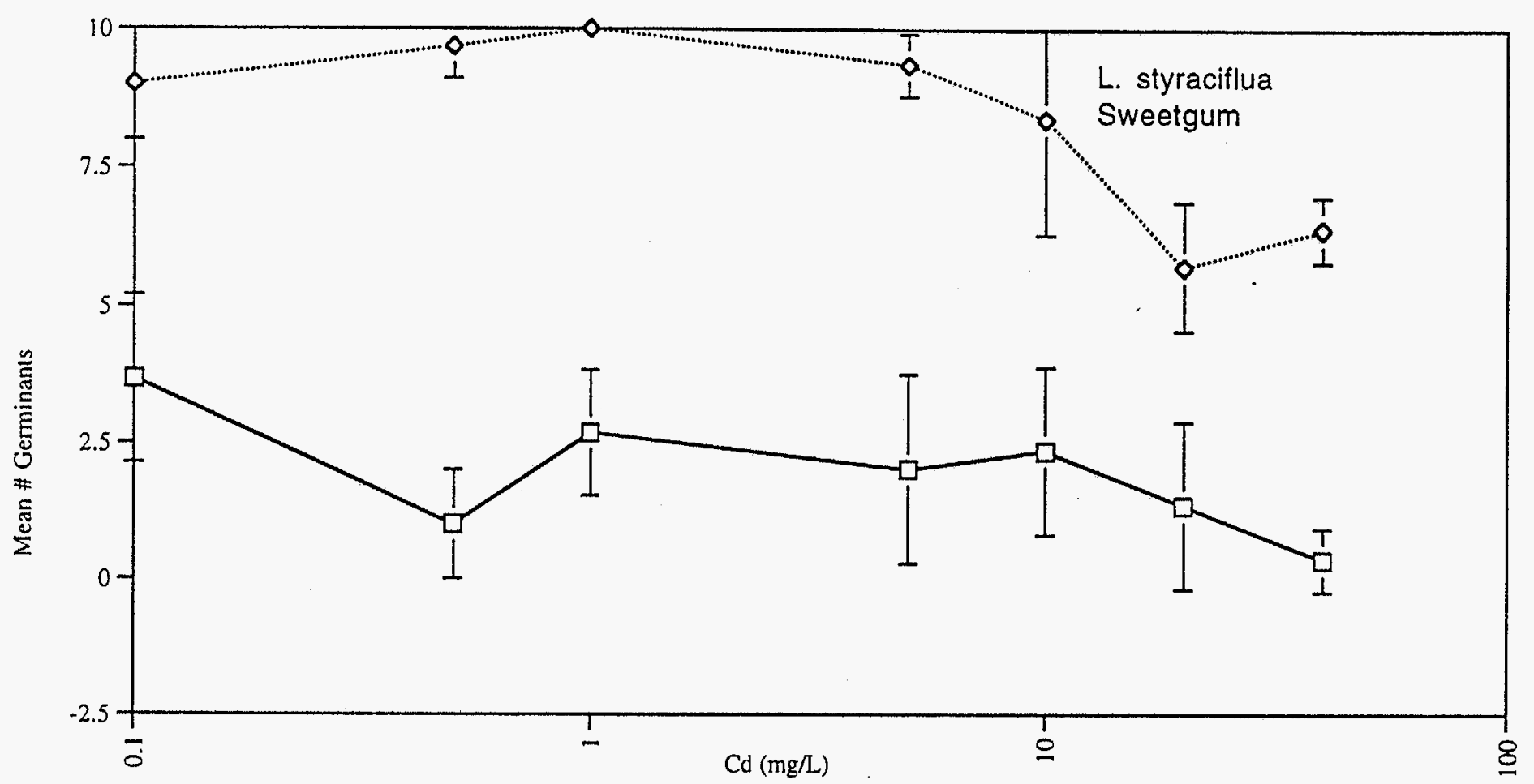

Figure 63. Influence of cadmium on seed germination in L. styraciflua . Squares represent data taken on Day 5; diamonds represent data taken on Day 10. 


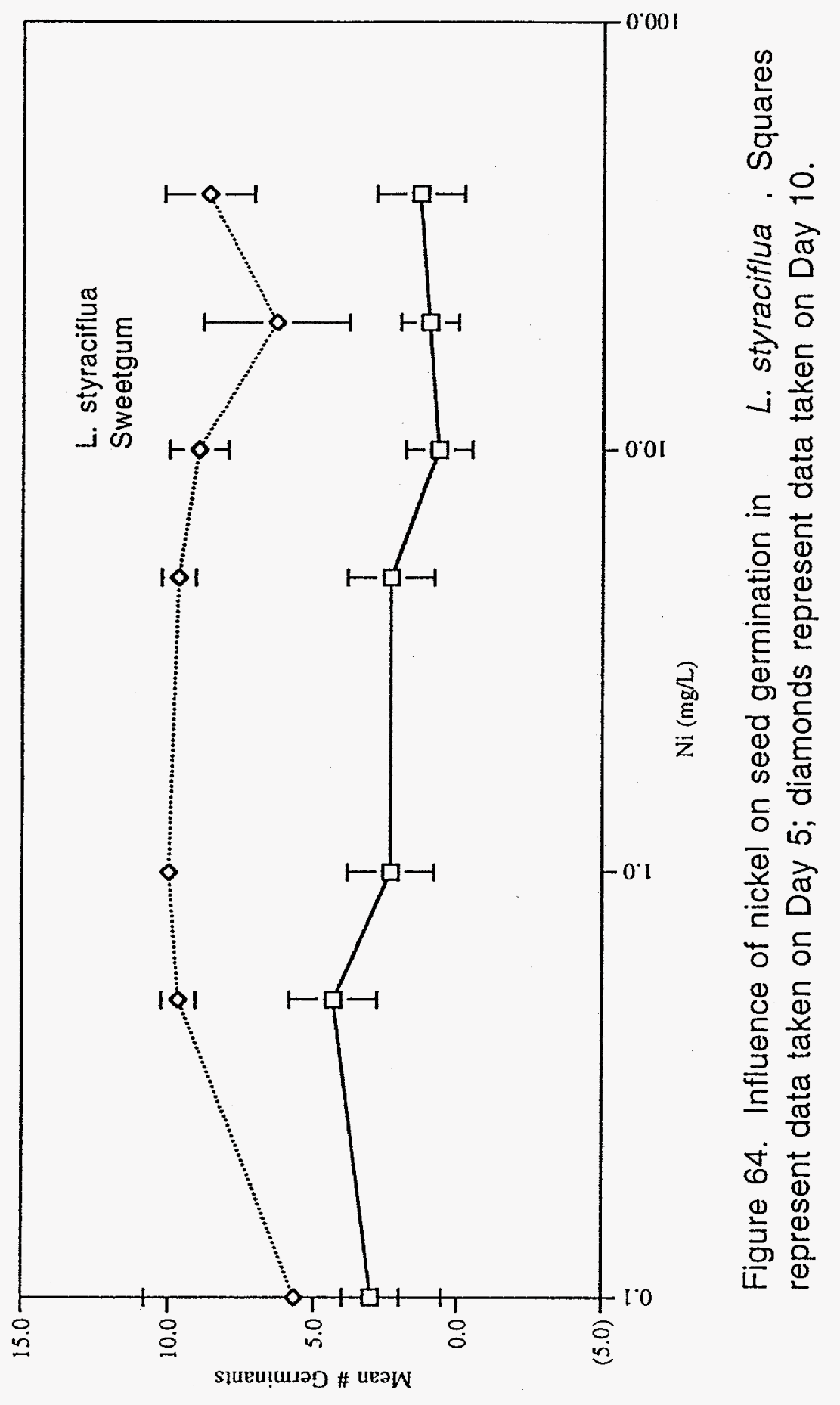




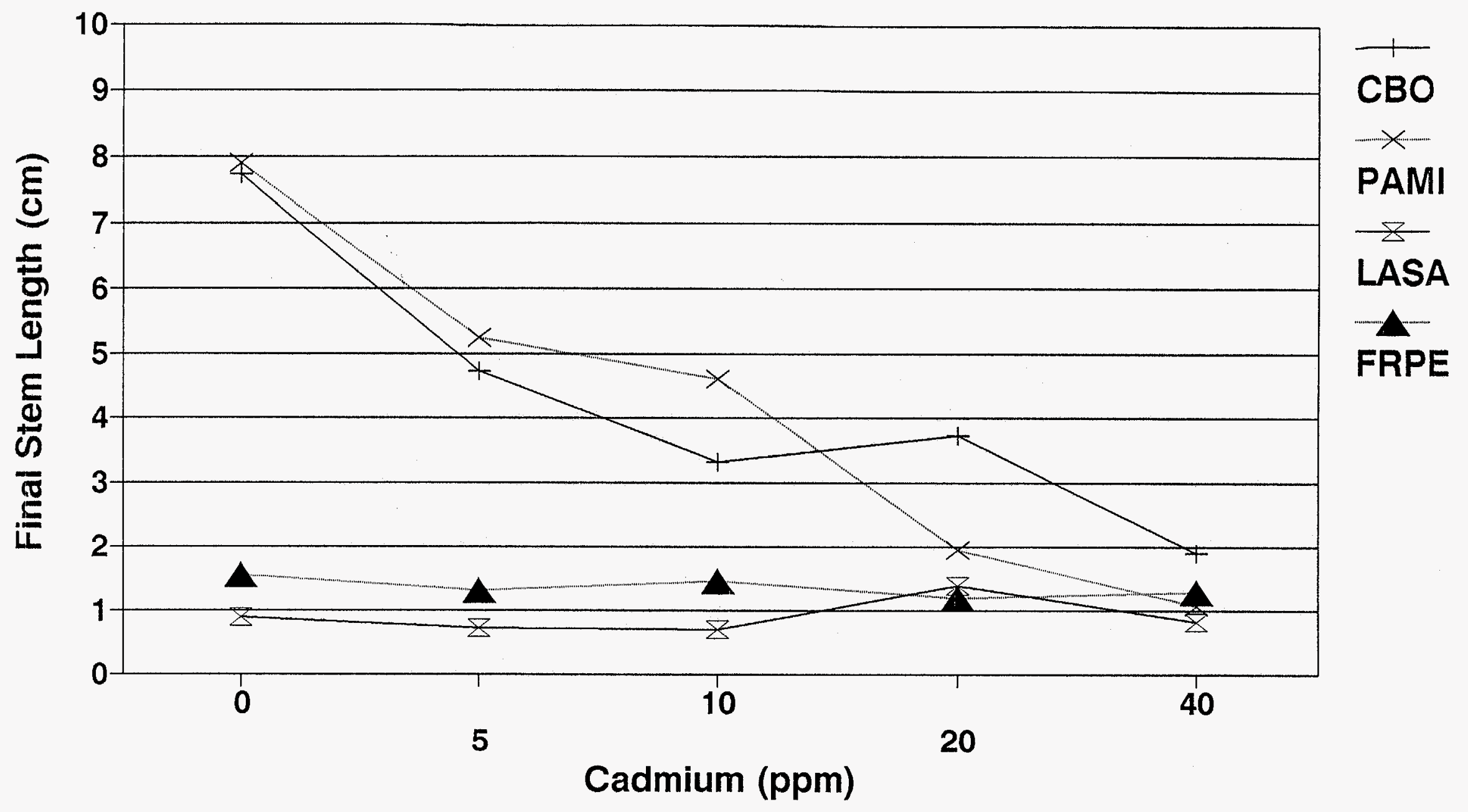

Figure 65. Stem elongation of four species to cadmium dose rates. 


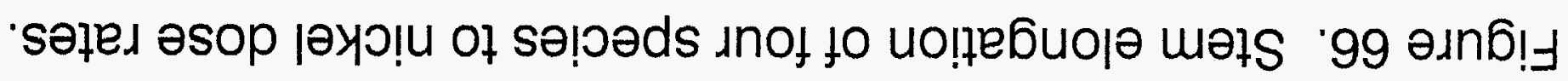

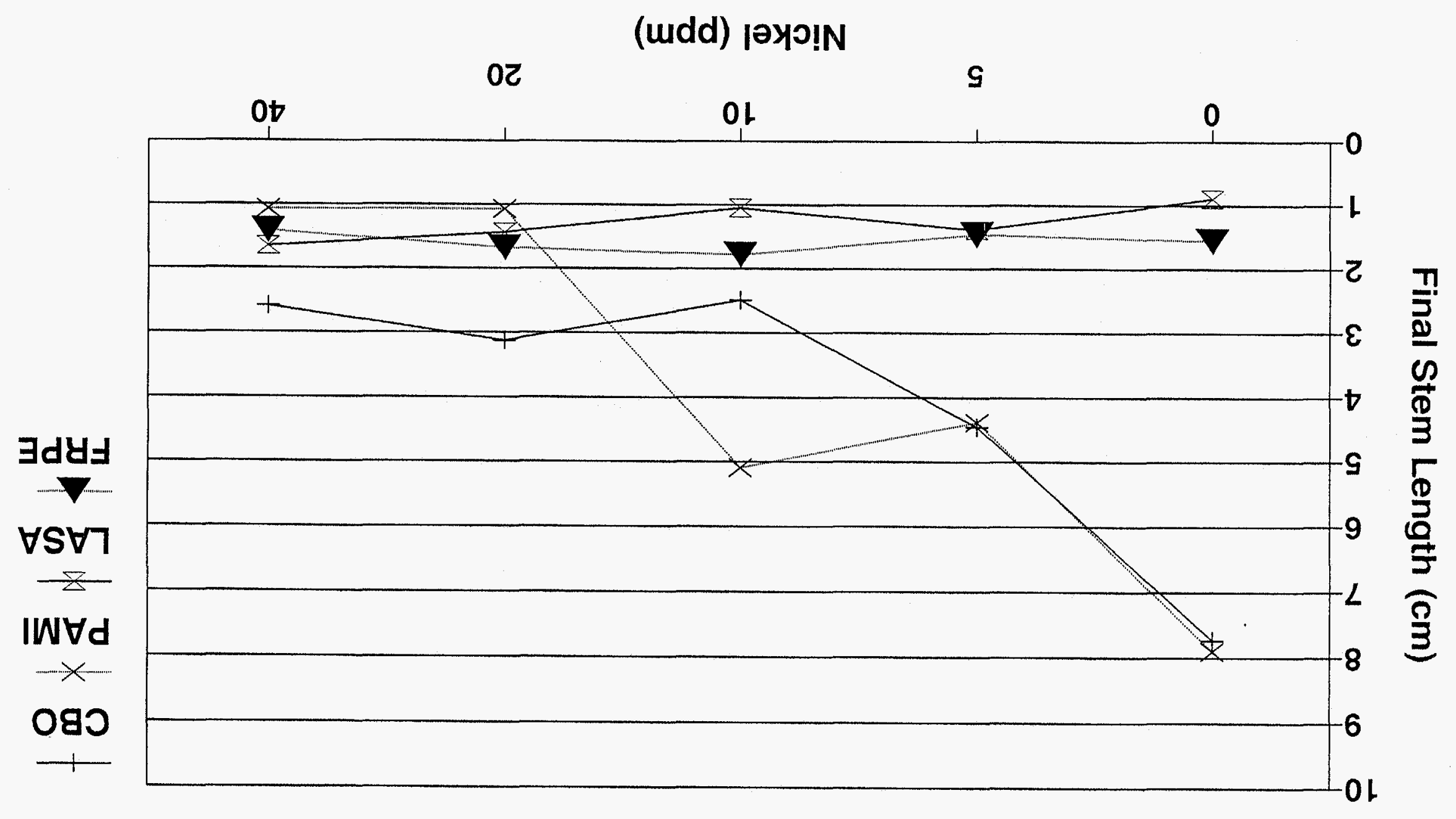




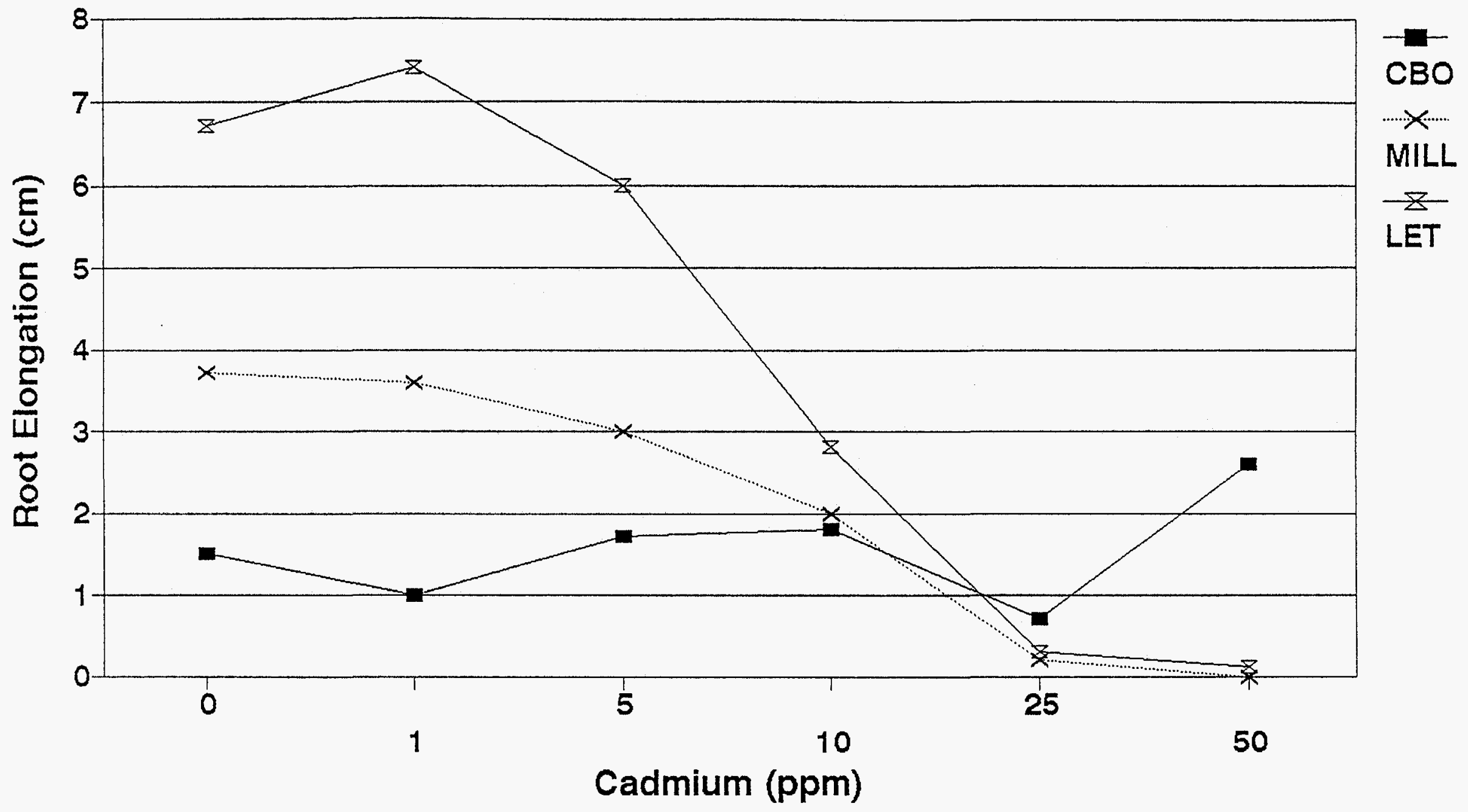

Figure 67. Root elongation in relation to dose rate for three species. $\mathrm{CBO}=$ cherrybark oak, MILL = millet, LET = lettuce 
中品层怗

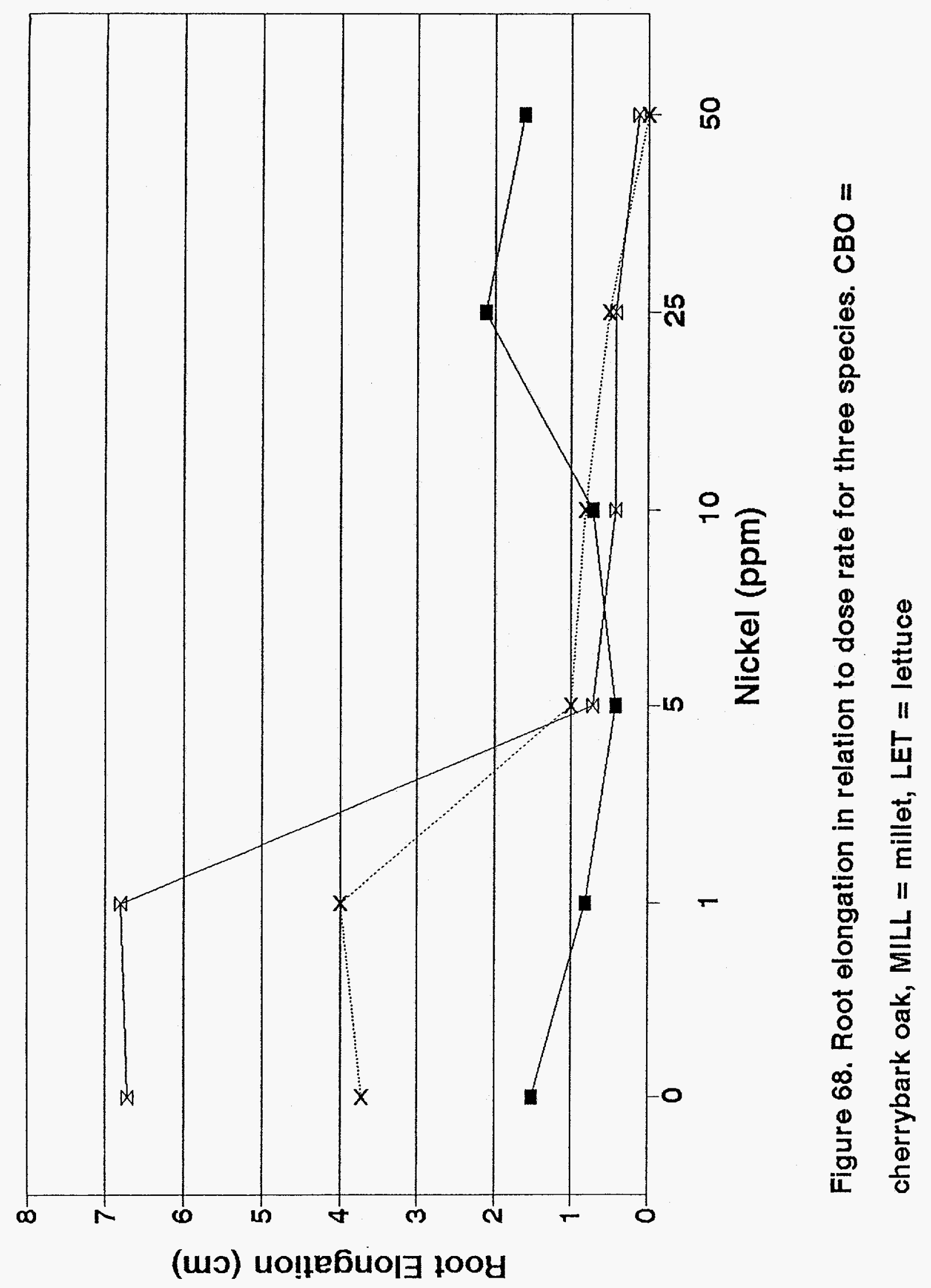


Appendix 1. Statistical analysis of seed germination data.

Probit analysis was performed on the seed germination data using TOXCALC statistical software from Tidepool Scientific Software. 
Species Chem NOEL(ppm) LOEL(ppm) EC Value(ppm)

\begin{tabular}{|c|c|c|c|c|}
\hline LIST & PCE & 10 & 50 & UTA \\
\hline LIST & NI & 50 & $>50$ & UTA \\
\hline LIST & MEOH & 0.5 & 5 & UTA \\
\hline LIST & $\mathrm{Cd}$ & 10 & 50 & UTA \\
\hline LIST & ATRA & 1 & 5 & UTA \\
\hline LIST & ANTH & 1 & 5 & UTA \\
\hline LASA & PCE & UTA & UTA & UTA \\
\hline LASA & NI & 50 & $>50$ & UTA \\
\hline LASA & MEOH & 5 & $>5$ & UTA \\
\hline LASA & $\mathrm{Cd}$ & UTA & UTA & UTA \\
\hline LASA & ATRA & 50 & $>50$ & UTA \\
\hline LASA & ANTH & 50 & $>50$ & UTA \\
\hline CEOC & PCE & 50 & $>50$ & UTA \\
\hline CEOC & NI & 25 & 50 & UTA \\
\hline CEOC & MEOH & 5 & 25 & UTA \\
\hline CEOC & $\mathrm{Cd}$ & 25 & 50 & UTA \\
\hline CEOC & ATRA & 25 & 50 & $\mathrm{ECOS}=17.97$ \\
\hline CEOC & ANTH & 25 & 50 & UTA \\
\hline RASA & PCE & 50 & $>50$ & UTA \\
\hline RASA & $\mathrm{NI}$ & 50 & $>50$ & UTA \\
\hline RASA & $\mathrm{MEOH}$ & 5 & $>5$ & $E C 10=2.38$ \\
\hline RASA & $\mathrm{Cd}$ & 50 & $>50$ & UTA \\
\hline RASA & ATRA & 50 & $>50$ & UTA \\
\hline RASA & ANTH & 50 & $>50$ & $E C 10=28.16$ \\
\hline QUFA & PCE & 50 & $>50$ & UTA \\
\hline QUFA & $\mathrm{N} !$ & 50 & $>50$ & UTA \\
\hline QUFA & $\mathrm{MEOH}$ & 25 & $>25$ & UTA \\
\hline QUFA & $\mathrm{Cd}$ & 50 & $>50$ & UTA \\
\hline QUFA & ATRA & 50 & $>50$ & UTA \\
\hline QUFA & ANTH & 50 & $>50$ & UTA \\
\hline PAMI & PCE & 50 & $>50$ & UTA \\
\hline PAMI & NI & 50 & $>50$ & $\mathrm{EC} 10=49.56$ \\
\hline PAMI & $\mathrm{MEOH}$ & 2.5 & 5 & $\mathrm{EC} 10=2.61$ \\
\hline PAMI & $\mathrm{Cd}$ & 25 & 50 & $\mathrm{EC} 10=29.6$ \\
\hline PAMI & ATRA & 50 & $>50$ & $E C 10=34.84$ \\
\hline PAMI & ANTH & 25 & 50 & $E C 10=9.94$ \\
\hline SACE & PCE & 50 & $>50$ & UTA \\
\hline SACE & $\mathrm{NI}$ & 50 & $>50$ & UTA \\
\hline SACE & $\mathrm{MEOH}$ & 25 & $>25$ & UTA \\
\hline SACE & $\mathrm{Cd}$ & 50 & $>50$ & UTA \\
\hline SACE & ATRA & 50 & $>50$ & UTA \\
\hline SACE & ANTH & 50 & $>50$ & UTA \\
\hline
\end{tabular}




\begin{tabular}{|c|c|c|c|c|c|c|c|}
\hline \multicolumn{8}{|c|}{-Proportion Germinated } \\
\hline $\begin{array}{l}\text { Start Date: } \\
\text { End Date: } \\
\text { Sample Date: } \\
\text { Comments: }\end{array}$ & & & $\begin{array}{l}\text { Test ID: } \\
\text { Lab ID: } \\
\text { Protocol: }\end{array}$ & $\begin{array}{r}2 \\
\text { MBP } 90-\end{array}$ & Anderson et al. & $\begin{array}{l}\text { Sample ID: } \\
\text { Sample Type: } \\
\text { Test Species: }\end{array}$ & CEOC \\
\hline Conc-\% & 1 & 2 & 3 & 4 & 5 & & \\
\hline B-Control & 0.4000 & 0.8000 & 0.8000 & 0.2000 & 0.2000 & & \\
\hline 0.5 & 0.6000 & 0.8000 & 0.6000 & 0.8000 & 0.4000 & & \\
\hline 5 & 0.4000 & 0.6000 & 0.4000 & 0.4000 & 0.2000 & & \\
\hline 25 & 0.2000 & 0.0000 & 0.4000 & 0.4000 & 0.0000 & & \\
\hline
\end{tabular}

\begin{tabular}{|c|c|c|c|c|c|c|c|c|c|c|c|c|}
\hline \multirow[b]{2}{*}{ Conc-\% } & \multirow[b]{2}{*}{ Mean } & \multirow[b]{2}{*}{ N-Mean } & \multicolumn{5}{|c|}{ Transform: Arcsin Square Root } & \multicolumn{3}{|c|}{ 1-Tailed } & \multirow{2}{*}{$\begin{array}{l}\text { Number } \\
\text { Resp }\end{array}$} & \multirow{2}{*}{$\begin{array}{l}\text { Total } \\
\text { Number }\end{array}$} \\
\hline & & & Mean & Min & $\operatorname{Max}$ & CV\% & $\mathbf{N}$ & t-Stat & Critical & MSD & & \\
\hline B-Control & 0.4800 & 1.0000 & 0.7653 & 0.4636 & 1.1071 & 42.454 & 5 & & & & $\overline{5}$ & $\overline{12}$ \\
\hline 0.5 & 0.6400 & 1.3333 & 0.9342 & 0.6847 & 1.1071 & 19.050 & 5 & -1.010 & 2.230 & 0.3730 & 5 & 16 \\
\hline 5 & 0.4000 & 0.8333 & 0.6808 & 0.4636 & 0.8861 & 21.953 & 5 & 0.505 & 2.230 & 0.3730 & 5 & 10 \\
\hline *25 & 0.2000 & 0.4167 & 0.3666 & 0.0000 & 0.6847 & 94.548 & 5 & 2.384 & 2.230 & 0.3730 & 3 & 5 \\
\hline
\end{tabular}

\begin{tabular}{|c|c|c|c|c|c|c|c|c|c|c|c|c|}
\hline \multicolumn{7}{|c|}{ Auxiliary Tests } & \multicolumn{2}{|l|}{ Statistic } & \multicolumn{2}{|l|}{ Critical } & Skew & Kurt \\
\hline \multicolumn{7}{|c|}{ Shapiro-Wilk's Test indicates normal distribution $(p>0.01)$} & 0.9262 & & 0.868 & & -0.0644 & -1.2416 \\
\hline \multicolumn{7}{|c|}{ Bartlett's Test indicates equal variances $(p=0.31)$} & 3.5512 & & 11.345 & & & \\
\hline \multicolumn{3}{|c|}{ Hypothesis Test (1-tail, 0.05) } & NOEC & LOEC & ChV & TU & MSDu & MSB & MSE & F-Stat & F-Prob & $\mathrm{df}$ \\
\hline \multicolumn{3}{|c|}{ Dunnett's Test } & 5 & 25 & 11.18 & 20 & 0.3337 & 0.2832 & 0.0699 & 4.0502 & 0.0255 & 3,16 \\
\hline \multicolumn{13}{|c|}{ Maximum Likelihood-Probit } \\
\hline Parameter & Value & SE & \multicolumn{3}{|c|}{ 95\% Fiducial Limits } & Control & Chi-Sq & Critical & P-value & Mu & Sigma & Iter \\
\hline Slope & 0.9548 & 2.2106 & -3.3779 & 5.2875 & & 0.4167 & 0.0158 & 6.6349 & 0.9 & 1.8338 & 1.0473 & 6 \\
\hline Intercept & 3.2491 & 2.5588 & -1.7662 & 8.2644 & & & & & & & & \\
\hline TSCR & 0.4064 & 0.1228 & 0.1658 & 0.6471 & & & 1.0 & & & & & \\
\hline Point & Probits & $\%$ & $95 \%$ Fidu & cial Lim & & & 09 & & & & & \\
\hline EC01 & 2.674 & 0.2496 & & & & & 0.5 & & & & & \\
\hline EC05 & 3.355 & 1.2915 & & & & & 0.8 & & & & & \\
\hline EC10 & 3.718 & 3.1016 & & & & & 0.7 & & & & & \\
\hline EC15 & 3.964 & 5.6016 & & & & & & & & & & \\
\hline EC20 & 4.158 & 8.9607 & & & & & 0.6 & & & & & \\
\hline EC25 & 4.326 & 13.409 & & & & & 0.5 & & & & & \\
\hline EC40 & 4.747 & 37.023 & & & & & & & & & & \\
\hline EC50 & 5.000 & 68.204 & & & & & 0.4 & & & & & \\
\hline EC60 & 5.253 & 125.65 & & & & & 0.3 & & & & & \\
\hline EC75 & 5.674 & 346.92 & & & & & 0.2 & & & & & \\
\hline EC80 & 5.842 & 519.12 & & & & & & & & & & \\
\hline EC85 & 6.036 & 830.44 & & & & & 0.1 & & & & & \\
\hline EC90 & 6.282 & 1499.8 & & & & & 0.0 & & & & & \\
\hline EC95 & 6.645 & 3601.9 & & & & & 0 & 1.1 & 10 & 1000 & 10000 & \\
\hline EC99 & 7.326 & 18633 & & & & & & & & & & \\
\hline
\end{tabular}

Dose $\%$ 
Date:

Date:

ple Date:

iments:
Test ID:

Lab 1D:

Protocol: MBP 90-Anderson et al.

\begin{tabular}{rccccc}
\hline onc-ppm & $\mathbf{1}$ & $\mathbf{2}$ & $\mathbf{3}$ & $\mathbf{4}$ & $\mathbf{5}$ \\
\hline B-Control & 0.4000 & 0.8000 & 0.8000 & 0.2000 & 0.2000 \\
0.5 & 0.2000 & 0.4000 & 0.4000 & 0.8000 & 0.8000 \\
1 & 0.4000 & 1.0000 & 0.2000 & 0.6000 & 0.6000 \\
5 & 0.8000 & 0.8000 & 0.8000 & 0.6000 & 0.8000 \\
10 & 1.0000 & 0.8000 & 0.8000 & 1.0000 & 0.8000 \\
25 & 0.6000 & 0.8000 & 0.6000 & 0.4000 & 0.8000 \\
50 & 0.0000 & 0.0000 & 0.0000 & 0.0000 & 0.0000
\end{tabular}

Sample ID:

Sample Type:

Test Species:
CEOC

\begin{tabular}{|c|c|c|c|c|c|c|c|c|c|c|c|}
\hline \multirow{2}{*}{ pnc-ppm } & \multirow[b]{2}{*}{ Mean } & \multirow[b]{2}{*}{ N-Mean } & \multicolumn{5}{|c|}{ Transform: Arcsin Square Root } & \multirow{2}{*}{$\begin{array}{l}\text { Rank } \\
\text { Sum }\end{array}$} & \multirow{2}{*}{$\begin{array}{l}\text { 1-Tailed } \\
\text { Critical } \\
\end{array}$} & \multirow[b]{3}{*}{5} & \multirow[b]{3}{*}{12} \\
\hline & & & Mean & Min & Max & $\mathrm{CV} \%$ & $\mathbf{N}$ & & & & \\
\hline B-Control & 0.4800 & 1.0000 & 0.7653 & 0.4636 & 1.1071 & 42.454 & 5 & & & & \\
\hline 0.5 & 0.5200 & 1.0833 & 0.8095 & 0.4636 & 1.1071 & 35.372 & 5 & 29.00 & 16.00 & 5 & 13 \\
\hline 1 & 0.5600 & 1.1667 & 0.8532 & 0.4636 & 1.3453 & 38.181 & 5 & 29.50 & 16.00 & 4 & 14 \\
\hline 5 & 0.7600 & 1.5833 & 1.0629 & 0.8861 & 1.1071 & 9.301 & 5 & 34.00 & 16.00 & 5 & 19 \\
\hline 10 & 0.8800 & 1.8333 & 1.2024 & 1.1071 & 1.3453 & 10.848 & 5 & 37.00 & 16.00 & 3 & 22 \\
\hline 25 & 0.6400 & 1.3333 & 0.9342 & 0.6847 & 1.1071 & 19.050 & 5 & 31.50 & 16.00 & 5 & 16 \\
\hline *50 & 0.0000 & 0.0000 & 0.0045 & 0.0045 & 0.0045 & 0.000 & 5 & 15.00 & 16.00 & 0.0005 & 0.0005 \\
\hline \multicolumn{7}{|l|}{ iliary Tests } & \multicolumn{2}{|c|}{ Statistic } & Critical & Skew & Kurt \\
\hline \multicolumn{7}{|c|}{$\begin{array}{l}\text { Diro-Wilk's Test indicates normal distribution }(p>0.01) \\
\text { ality of variance cannot be confirmed }\end{array}$} & 0.9708 & \multicolumn{2}{|r|}{0.91} & 0.2962 & 0.0829 \\
\hline \multirow{2}{*}{\multicolumn{3}{|c|}{$\begin{array}{l}\text { othesis Test (1-tail, 0.05) } \\
\text { I's Many-One Rank Test }\end{array}$}} & NOEC & LOEC & ChV & TU & & & & & \\
\hline & & & 25 & 50 & 5.355 & & & & & & \\
\hline
\end{tabular}




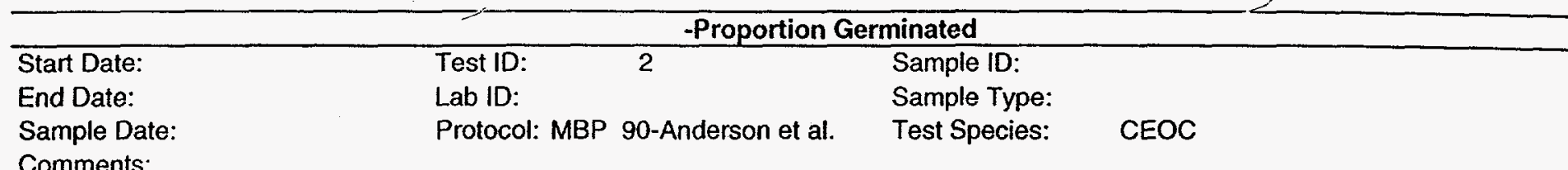

Comments:

\begin{tabular}{|c|c|c|c|c|c|}
\hline Conc- $\%$ & 1 & 2 & 3 & 4 & 5 \\
\hline B-Control & 0.4000 & 0.8000 & 0.8000 & 0.2000 & 0.2000 \\
\hline 0.1 & 0.6000 & 0.4000 & 0.2000 & 0.2000 & 0.6000 \\
\hline 0.5 & 0.8000 & 0.8000 & 0.4000 & 0.6000 & 0.8000 \\
\hline 1 & 0.8000 & 0.4000 & 0.8000 & 0.4000 & 0.4000 \\
\hline 5 & 0.2000 & 0.8000 & 0.4000 & 0.6000 & 0.0000 \\
\hline 10 & 0.6000 & 0.4000 & 0.8000 & 0.4000 & 0.6000 \\
\hline 50 & 1.0000 & 0.8000 & 0.2000 & 0.2000 & 0.8000 \\
\hline
\end{tabular}

\begin{tabular}{|c|c|c|c|c|c|c|c|c|c|c|c|c|}
\hline \multirow[b]{2}{*}{ Conc-\% } & \multirow[b]{2}{*}{ Mean } & \multirow[b]{2}{*}{ N-Mean } & \multicolumn{5}{|c|}{ Transform: Arcsin Square Root } & \multicolumn{3}{|c|}{ 1-Tailed } & & \\
\hline & & & Mean & $\operatorname{Min}$ & Max & CV\% & $\mathbf{N}$ & t-Stat & Critical & MSD & & \\
\hline B-Control & 0.4800 & 1.0000 & 0.7653 & 0.4636 & 1.1071 & 42.454 & 5 & & & & 5 & 12 \\
\hline 0.1 & 0.4000 & 0.8333 & 0.6768 & 0.4636 & 0.8861 & 31.213 & 5 & 0.471 & 2.409 & 0.4523 & 5 & 10 \\
\hline 0.5 & 0.6800 & 1.4167 & 0.9784 & 0.6847 & 1.1071 & 19.425 & 5 & -1.135 & 2.409 & 0.4523 & 5 & 17 \\
\hline 1 & 0.5600 & 1.1667 & 0.8537 & 0.6847 & 1.1071 & 27.103 & 5 & -0.471 & 2.409 & 0.4523 & 5 & 14 \\
\hline 5 & 0.4000 & 0.8333 & 0.6283 & 0.0000 & 1.1071 & 67.561 & 5 & 0.729 & 2.409 & 0.4523 & 4 & 10 \\
\hline 10 & 0.5600 & 1.1667 & 0.8497 & 0.6847 & 1.1071 & 20.667 & 5 & -0.450 & 2.409 & 0.4523 & 5 & 14 \\
\hline 50 & 0.6000 & 1.2500 & 0.8974 & 0.4636 & 1.3453 & 45.432 & 5 & -0.704 & 2.409 & 0.4523 & 4 & 15 \\
\hline
\end{tabular}

\begin{tabular}{|c|c|c|c|c|c|c|c|c|c|c|}
\hline \multirow{2}{*}{\multicolumn{5}{|c|}{ Auxiliary Tests }} & \multicolumn{2}{|l|}{ Statistic } & \multicolumn{2}{|l|}{ Critical } & \multirow{2}{*}{$\frac{\text { Skew }}{-0.2397}$} & \multirow{2}{*}{$\frac{\text { Kurt }}{-0.5857}$} \\
\hline & distribu & $n(p>0$ & & & 0.9652 & & 0.91 & & & \\
\hline Bartlett's Test indicates equal & $\operatorname{ces}(p=$ & .44) & & & 5.8168 & & 16.812 & & & \\
\hline Hypothesis Test (1-tail, 0.05) & NOEC & LOEC & ChV & TU & MSDu & MSB & MSE & F-Stat & F-Prob & df \\
\hline Dunnett's Test & 50 & $>50$ & & 2 & 0.3851 & 0.0768 & 0.0882 & 0.8714 & 0.5281 & 6,28 \\
\hline
\end{tabular}




\section{-Proportion Germinated}

Date:

Test ID:

62

Sample ID:

Date:

Lab ID:

Sample Type:

ple Date:

Protocol: MBP 90-Anderson et al. Test Species:

LASA

ments:

\begin{tabular}{|rccccc|}
\hline Ponc-\% & 1 & 2 & 3 & 4 & 5 \\
\hline B-Control & 1.0000 & 1.0000 & 1.0000 & 1.0000 & 1.0000 \\
0.5 & 1.0000 & 1.0000 & 1.0000 & 1.0000 & 1.0000 \\
1 & 1.0000 & 1.0000 & 1.0000 & 1.0000 & 1.0000 \\
5 & 1.0000 & 1.0000 & 1.0000 & 1.0000 & 1.0000 \\
10 & 1.0000 & 1.0000 & 1.0000 & 1.0000 & 1.0000 \\
25 & 1.0000 & 1.0000 & 1.0000 & 1.0000 & 1.0000 \\
50 & 0.6000 & 1.0000 & 1.0000 & 1.0000 & 1.0000
\end{tabular}

\begin{tabular}{|c|c|c|c|c|c|c|c|c|c|}
\hline \multirow{2}{*}{ Sonc-\% } & \multirow[b]{2}{*}{ Mean } & \multirow[b]{2}{*}{ N-Mean } & \multicolumn{5}{|c|}{ Transform: Arcsin Square Root } & \multirow{2}{*}{$\begin{array}{l}\text { Rank } \\
\text { Sum }\end{array}$} & \multirow{2}{*}{$\begin{array}{l}\text { 1-Tailed } \\
\text { Critical }\end{array}$} \\
\hline & & & Mean & Min & Max & CV\% & $\mathbf{N}$ & & \\
\hline B-Control & 1.0000 & 1.0000 & 1.3453 & 1.3453 & 1.3453 & 0.000 & 5 & & \\
\hline 0.5 & 1.0000 & 1.0000 & 1.3453 & 1.3453 & 1.3453 & 0.000 & 5 & 27.50 & 16.00 \\
\hline 1 & 1.0000 & 1.0000 & 1.3453 & 1.3453 & 1.3453 & 0.000 & 5 & 27.50 & 16.00 \\
\hline 5 & 1.0000 & 1.0000 & 1.3453 & 1.3453 & 1.3453 & 0.000 & 5 & 27.50 & 16.00 \\
\hline 10 & 1.0000 & 1.0000 & 1.3453 & 1.3453 & 1.3453 & 0.000 & 5 & 27.50 & 16.00 \\
\hline 25 & 1.0000 & 1.0000 & 1.3453 & 1.3453 & 1.3453 & 0.000 & 5 & 27.50 & 16.00 \\
\hline 50 & 0.9200 & 0.9200 & 1.2534 & 0.8861 & 1.3453 & 16.384 & 5 & 25.00 & 16.00 \\
\hline
\end{tabular}

liary Tests

Statistic

Critical

Skew Kurt

iro-Wilk's Test indicates non-normal distribution ( $p<=0.01$ )

0.3883

0.91

$-4.148623 .085$

lity of variance cannot be confirmed

thesis Test (1-tail, 0.05)

's Many-One Rank Test

$\begin{array}{ccc}\text { NOEC } & \text { LOEC } & \text { ChV } \\ 50 & >50 & \end{array}$

TU

2 


\begin{tabular}{|c|c|c|c|c|c|c|c|c|c|c|c|}
\hline \multicolumn{10}{|c|}{-Proportion Germinated } & & \\
\hline \multirow{3}{*}{$\begin{array}{l}\text { Start Date: } \\
\text { End Date: } \\
\text { Sample Date: } \\
\text { Comments: } \\
\end{array}$} & \multirow[b]{4}{*}{1} & \multirow[b]{4}{*}{2} & \multirow{3}{*}{$\begin{array}{l}\text { Test ID: } \\
\text { Lab ID: } \\
\text { Protocol: }\end{array}$} & \multicolumn{2}{|l|}{62} & \multirow{2}{*}{\multicolumn{3}{|c|}{$\begin{array}{l}\text { Sample ID: } \\
\text { Sample Type: }\end{array}$}} & \multirow[b]{3}{*}{ LASA } & & \\
\hline & & & & \multirow{2}{*}{\multicolumn{3}{|c|}{ MBP 90-Anderson et al. }} & & & & & \\
\hline & & & & & & & \multicolumn{2}{|c|}{ Test Species: } & & & \\
\hline Conc- $\%$ & & & 3 & 4 & 5 & & & & & & \\
\hline B-Control & 1.0000 & 1.0000 & 1.0000 & 1.0000 & 1.0000 & & & & & & \\
\hline 0.5 & 1.0000 & 1.0000 & 1.0000 & 1.0000 & 1.0000 & & & & & & \\
\hline 1 & 1.0000 & 1.0000 & 1.0000 & 1.0000 & 1.0000 & & & & & & \\
\hline 5 & 1.0000 & 1.0000 & 1.0000 & 1.0000 & 1.0000 & & & & & & \\
\hline 10 & 1.0000 & 1.0000 & 1.0000 & 1.0000 & 1.0000 & & & & & & \\
\hline 25 & 1.0000 & 1.0000 & 1.0000 & 0.8000 & 1.0000 & & & & & & \\
\hline \multirow[t]{2}{*}{50} & 1.0000 & 1.0000 & 1.0000 & 1.0000 & 1.0000 & & & & & & \\
\hline & & & \multicolumn{5}{|c|}{ Transform: Arcsin Square Root } & \multirow{2}{*}{$\begin{array}{l}\text { Rank } \\
\text { Sum }\end{array}$} & \multirow{2}{*}{$\begin{array}{l}\text { 1-Tailed } \\
\text { Critical } \\
\end{array}$} & & \\
\hline Conc-\% & Mean & N-Mean & Mean & Min & Max & $\mathrm{CV} \%$ & $\mathbf{N}$ & & & & \\
\hline B-Control & 1.0000 & 1.0000 & 1.3453 & 1.3453 & 1.3453 & 0.000 & 5 & & & & \\
\hline 0.5 & 1.0000 & 1.0000 & 1.3453 & 1.3453 & 1.3453 & 0.000 & 5 & 27.50 & 16.00 & & \\
\hline 1 & 1.0000 & 1.0000 & 1.3453 & 1.3453 & 1.3453 & 0.000 & 5 & 27.50 & 16.00 & & \\
\hline 5 & 1.0000 & 1.0000 & 1.3453 & 1.3453 & 1.3453 & 0.000 & 5 & 27.50 & 16.00 & & \\
\hline 10 & 1.0000 & 1.0000 & 1.3453 & 1.3453 & 1.3453 & 0.000 & 5 & 27.50 & 16.00 & & \\
\hline 25 & 0.9600 & 0.9600 & 1.2977 & 1.1071 & 1.3453 & 8.207 & 5 & 25.00 & 16.00 & & \\
\hline 50 & 1.0000 & 1.0000 & 1.3453 & 1.3453 & 1.3453 & 0.000 & 5 & 27.50 & 16.00 & & \\
\hline \multicolumn{7}{|l|}{ Auxiliary Tests } & Statistic & & Critical & Skew & Kurt \\
\hline \multicolumn{7}{|c|}{$\begin{array}{l}\text { Shapiro-Wilk's Test indicates non-normal distribution }(p<=0.01) \\
\text { Equality of variance cannot be confirmed }\end{array}$} & 0.3883 & & 0.91 & -4.1486 & 23.085 \\
\hline \multirow{2}{*}{\multicolumn{3}{|c|}{ Hypothesis Test (1-tail, 0.05$)$}} & NOEC & LOEC & ChV & TU & & & & & \\
\hline & & & 50 & $>50$ & & 2 & & & & & \\
\hline
\end{tabular}


Date:

Date:

ple Date:

ments:

\begin{tabular}{rccccc|}
\hline nc-ppm & $\mathbf{1}$ & $\mathbf{2}$ & $\mathbf{3}$ & $\mathbf{4}$ & $\mathbf{5}$ \\
\hline B-Control & 1.0000 & 1.0000 & 1.0000 & 1.0000 & 1.0000 \\
0.1 & 1.0000 & 1.0000 & 1.0000 & 1.0000 & 1.0000 \\
0.2 & 1.0000 & 1.0000 & 1.0000 & 1.0000 & 1.0000 \\
0.5 & 1.0000 & 1.0000 & 1.0000 & 1.0000 & 1.0000 \\
1 & 1.0000 & 1.0000 & 1.0000 & 1.0000 & 1.0000 \\
2.5 & 1.0000 & 1.0000 & 1.0000 & 1.0000 & 1.0000 \\
5 & 1.0000 & 0.8000 & 1.0000 & 0.8000 & 0.8000
\end{tabular}

-Proportion Germinated

Test ID: $\quad 70 \quad$ Sample ID:

Lab ID: $\quad$ Sample Type:

Protocol: MBP 90-Anderson et al. Test Species:

LASA.MEOH

\begin{tabular}{|c|c|c|c|c|c|c|c|c|c|c|c|}
\hline \multirow[b]{2}{*}{ nc-ppm } & \multirow[b]{2}{*}{ Mean } & \multirow[b]{2}{*}{ N-Mean } & \multicolumn{5}{|c|}{ Transform: Arcsin Square Root } & \multirow{2}{*}{$\begin{array}{l}\text { Rank } \\
\text { Sum }\end{array}$} & \multirow{2}{*}{$\begin{array}{l}\text { 1-Tailed } \\
\text { Critical }\end{array}$} & & \\
\hline & & & Mean & Min & Max & CV\% & $\mathbf{N}$ & & & & \\
\hline B-Control & 1.0000 & 1.0000 & 1.3453 & 1.3453 & 1.3453 & 0.000 & 5 & & & $\overline{0}$ & 25 \\
\hline 0.1 & 1.0000 & 1.0000 & 1.3453 & 1.3453 & 1.3453 & 0.000 & 5 & 27.50 & 16.00 & 0 & 25 \\
\hline 0.2 & 1.0000 & 1.0000 & 1.3453 & 1.3453 & 1.3453 & 0.000 & 5 & 27.50 & 16.00 & 0 & 25 \\
\hline 0.5 & 1.0000 & 1.0000 & 1.3453 & 1.3453 & 1.3453 & 0.000 & 5 & 27.50 & 16.00 & 0 & 25 \\
\hline 1 & 1.0000 & 1.0000 & 1.3453 & 1.3453 & 1.3453 & 0.000 & 5 & 27.50 & 16.00 & 0 & 25 \\
\hline 2.5 & 1.0000 & 1.0000 & 1.3453 & 1.3453 & 1.3453 & 0.000 & 5 & 27.50 & 16.00 & 0 & 25 \\
\hline 5 & 0.8800 & 0.8800 & 1.2024 & 1.1071 & 1.3453 & 10.848 & 5 & 20.00 & 16.00 & 3 & 22 \\
\hline
\end{tabular}

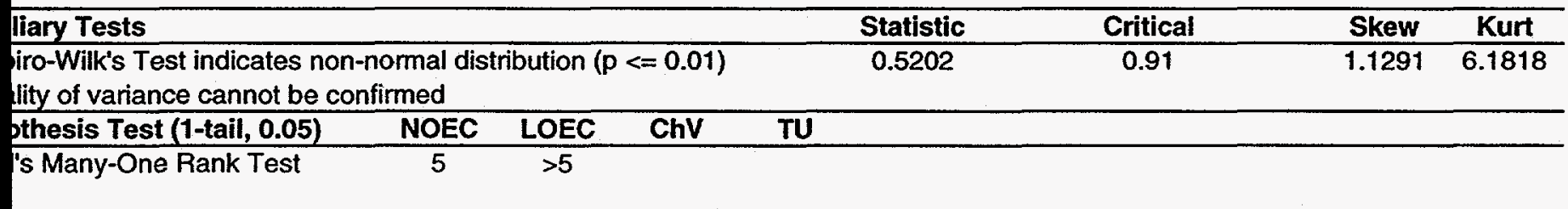




\begin{tabular}{|c|c|c|c|c|c|c|c|c|c|c|c|}
\hline \multicolumn{12}{|c|}{-Proportion Germinated } \\
\hline \multirow{2}{*}{$\begin{array}{l}\text { Date: } \\
\text { Date: } \\
\text { ple Date: } \\
\text { ments: } \\
\text { onc-\% }\end{array}$} & \multirow[b]{2}{*}{1} & \multicolumn{2}{|r|}{$\begin{array}{l}\text { Test ID: } \\
\text { Lab ID: } \\
\text { Protocol: }\end{array}$} & $\begin{array}{r}62 \\
\text { MBP } 90-\AA\end{array}$ & \multicolumn{2}{|c|}{ Anderson et al. } & \multicolumn{2}{|c|}{$\begin{array}{l}\text { Sample ID: } \\
\text { Sample Type: } \\
\text { Test Species: }\end{array}$} & \multirow[t]{2}{*}{ LASA } & & \\
\hline & & 2 & 3 & 4 & 5 & & & & & & \\
\hline B-Control & 1.0000 & 1.0000 & 1.0000 & 1.0000 & 1.0000 & & & & & & \\
\hline 0.5 & 1.0000 & 1.0000 & 1.0000 & 1.0000 & 1.0000 & & & & & & \\
\hline 1 & 1.0000 & 1.0000 & 1.0000 & 1.0000 & 1.0000 & & & & & & \\
\hline 5 & 1.0000 & 1.0000 & 1.0000 & 1.0000 & 1.0000 & & & & & & \\
\hline 10 & 1.0000 & 1.0000 & 1.0000 & 1.0000 & 1.0000 & & & & & & \\
\hline 25 & 1.0000 & 1.0000 & 1.0000 & 1.0000 & 1.0000 & & & & & & \\
\hline \multirow[b]{3}{*}{ onc-\% } & 0.8000 & 1.0000 & 1.0000 & 1.0000 & 1.0000 & & & & & & \\
\hline & & & \multicolumn{5}{|c|}{ Transform: Arcsin Square Root } & \multirow{2}{*}{$\begin{array}{l}\text { Rank } \\
\text { Sum }\end{array}$} & \multirow{2}{*}{$\begin{array}{l}\text { 1-Tailed } \\
\text { Critical }\end{array}$} & & \\
\hline & Mean & N-Mean & Mean & Min & Max & CV\% & $\overline{\mathbf{N}}$ & & & & \\
\hline B-Control & 1.0000 & 1.0000 & 1.3453 & 1.3453 & 1.3453 & 0.000 & 5 & & & & \\
\hline 0.5 & 1.0000 & 1.0000 & 1.3453 & 1.3453 & 1.3453 & 0.000 & 5 & 27.50 & 16.00 & & \\
\hline 1 & 1.0000 & 1.0000 & 1.3453 & 1.3453 & 1.3453 & 0.000 & 5 & 27.50 & 16.00 & & \\
\hline 5 & 1.0000 & 1.0000 & 1.3453 & 1.3453 & 1.3453 & 0.000 & 5 & 27.50 & 16.00 & & \\
\hline 10 & 1.0000 & 1.0000 & 1.3453 & 1.3453 & 1.3453 & 0.000 & 5 & 27.50 & 16.00 & & \\
\hline 25 & 1.0000 & 1.0000 & 1.3453 & 1.3453 & 1.3453 & 0.000 & 5 & 27.50 & 16.00 & & \\
\hline 50 & 0.9600 & 0.9600 & 1.2977 & 1.1071 & 1.3453 & 8.207 & 5 & 25.00 & 16.00 & & \\
\hline \multirow{2}{*}{\multicolumn{7}{|c|}{$\begin{array}{l}\text { liary Tests } \\
\text { iro-Wilk's Test indicates non-normal distribution ( } p<=0.01) \\
\text { lity of variance cannot be confirmed }\end{array}$}} & Statistic & & Critical & Skew & Kurt \\
\hline & & & & & & & 0.3883 & & 0.91 & -4.1486 & 23.085 \\
\hline \multirow{2}{*}{\multicolumn{3}{|c|}{$\begin{array}{l}\text { thesis Test (1-tail, } 0.05) \\
\text { 's Many-One Rank Test }\end{array}$}} & NOEC & LOEC & ChV & $\mathrm{TU}$ & & & & & \\
\hline & & & 50 & $>50$ & & 2 & & & & & \\
\hline
\end{tabular}




\begin{tabular}{|c|c|c|c|c|c|c|c|}
\hline \multicolumn{8}{|c|}{-Proportion Germinated } \\
\hline $\begin{array}{l}\text { Start Date: } \\
\text { End Date: } \\
\text { Sample Date: } \\
\text { Comments: }\end{array}$ & & & $\begin{array}{l}\text { Test ID: } \\
\text { Lab ID: } \\
\text { Protocol: }\end{array}$ & $\begin{array}{r}2 \\
2\end{array}$ & nderson et al. & $\begin{array}{l}\text { Sample ID: } \\
\text { Sample Type: } \\
\text { Test Species: }\end{array}$ & LIST \\
\hline Conc- $\%$ & 1 & 2 & 3 & 4 & 5 & & \\
\hline B-Control & 1.0000 & 0.8000 & 0.8000 & 0.8000 & 1.0000 & & \\
\hline 0.1 & 1.0000 & 1.0000 & 1.0000 & 1.0000 & 0.6000 & & \\
\hline 0.5 & 1.0000 & 0.8000 & 1.0000 & 1.0000 & 0.8000 & & \\
\hline 1 & 1.0000 & 1.0000 & 1.0000 & 1.0000 & 0.8000 & & \\
\hline 5 & 0.2000 & 0.6000 & 0.0000 & 0.0000 & 0.0000 & & \\
\hline 10 & 1.0000 & 1.0000 & 0.8000 & 0.8000 & 0.8000 & & \\
\hline 50 & 0.0000 & 0.0000 & 0.0000 & 0.0000 & 0.0000 & & \\
\hline
\end{tabular}

\begin{tabular}{|c|c|c|c|c|c|c|c|c|c|c|c|}
\hline \multirow[b]{2}{*}{ Conc-\% } & \multirow[b]{2}{*}{ Mean } & \multirow[b]{2}{*}{ N-Mean } & \multicolumn{5}{|c|}{ Transform: Arcsin Square Root } & \multirow{2}{*}{$\begin{array}{l}\text { Rank } \\
\text { Sum }\end{array}$} & \multirow{2}{*}{$\begin{array}{l}\text { 1-Tailed } \\
\text { Critical }\end{array}$} & \multirow[b]{3}{*}{3} & \multirow[b]{3}{*}{$2 ?$} \\
\hline & & & Mean & Min & $\operatorname{Max}$ & CV\% & $\mathbf{N}$ & & & & \\
\hline B-Control & 0.8800 & 1.0000 & 1.2024 & 1.1071 & 1.3453 & 10.848 & 5 & & & & \\
\hline 0.1 & 0.9200 & 1.0455 & 1.2534 & 0.8861 & 1.3453 & 16.384 & 5 & 31.00 & 16.00 & 1 & 23 \\
\hline 0.5 & 0.9200 & 1.0455 & 1.2500 & 1.1071 & 1.3453 & 10.434 & 5 & 30.00 & 16.00 & 2 & 23 \\
\hline 1 & 0.9600 & 1.0909 & 1.2977 & 1.1071 & 1.3453 & 8.207 & 5 & 32.50 & 16.00 & 1 & 24 \\
\hline *5 & 0.1600 & 0.1818 & 0.2699 & 0.0000 & 0.8861 & 147.686 & 5 & 15.00 & 16.00 & 2 & 4 \\
\hline 10 & 0.8800 & 1.0000 & 1.2024 & 1.1071 & 1.3453 & 10.848 & 5 & 27.50 & 16.00 & 3 & 22 \\
\hline${ }^{*} 50$ & 0.0000 & 0.0000 & 0.0045 & 0.0045 & 0.0045 & 0.000 & 5 & 15.00 & 16.00 & 0.0005 & 0.0005 \\
\hline \multicolumn{7}{|l|}{ Auxiliary Tests } & Statistic & \multicolumn{2}{|r|}{ Critical } & Skew & Kurt \\
\hline \multicolumn{7}{|c|}{$\begin{array}{l}\text { Shapiro-Wilk's Test indicates normal distribution }(p>0.01) \\
\text { Equality of variance cannot be confirmed }\end{array}$} & 0.9144 & \multicolumn{2}{|r|}{0.91} & 0.7569 & 3.4549 \\
\hline \multicolumn{3}{|c|}{ Hypothesis Test (1-tail, 0.05$)$} & NOEC & LOEC & ChV & TU & & & & & \\
\hline \multicolumn{3}{|c|}{ Steel's Many-One Rank Test } & $\overline{1}$ & 5 & 2.2361 & 100 & & & & & \\
\hline
\end{tabular}




\begin{tabular}{|c|c|c|c|c|c|c|c|c|c|c|c|}
\hline \multicolumn{12}{|c|}{-Proportion Germinated } \\
\hline $\begin{array}{l}\text { it Date: } \\
\text { d Date: } \\
\text { mple Date: } \\
\text { mments: }\end{array}$ & \multirow[b]{2}{*}{1} & \multirow[b]{2}{*}{2} & $\begin{array}{l}\text { Test ID: } \\
\text { Lab ID: } \\
\text { Protocol: }\end{array}$ & \multicolumn{3}{|c|}{2} & \multicolumn{2}{|c|}{$\begin{array}{l}\text { Sample ID: } \\
\text { Sample Type: } \\
\text { Test Species: }\end{array}$} & \multirow[t]{2}{*}{ LIST } & & \\
\hline Conc- $\%$ & & & 3 & 4 & 5 & & & & & & \\
\hline B-Control & 1.0000 & 0.8000 & 0.8000 & 0.8000 & 1.0000 & & & & & & \\
\hline 0.1 & 0.8000 & 1.0000 & 1.0000 & 0.8000 & 1.0000 & & & & & & \\
\hline 0.5 & 1.0000 & 1.0000 & 1.0000 & 1.0000 & 1.0000 & & & & & & \\
\hline 1 & 1.0000 & 1.0000 & 1.0000 & 0.6000 & 1.0000 & & & & & & \\
\hline 5 & 0.0000 & 0.0000 & 0.0000 & 0.0000 & 0.0000 & & & & & & \\
\hline 10 & 1.0000 & 1.0000 & 1.0000 & 1.0000 & 1.0000 & & & & & & \\
\hline 50 & 0.8000 & 0.0000 & 0.0000 & 0.0000 & 0.0000 & & & & & & \\
\hline \multirow[b]{2}{*}{ Conc-\% } & & & \multicolumn{5}{|c|}{ Transform: Arcsin Square Root } & Rank & 1-Tailed & & \\
\hline & Mean & N-Mean & Mean & Min & Max & CV\% & $\mathbf{N}$ & Sum & Critical & & \\
\hline B-Control & 0.8800 & 1.0000 & 1.2024 & 1.1071 & 1.3453 & 10.848 & 5 & & & 3 & 22 \\
\hline 0.1 & 0.9200 & 1.0455 & 1.2500 & 1.1071 & 1.3453 & 10.434 & 5 & 30.00 & 16.00 & 2 & 23 \\
\hline 0.5 & 1.0000 & 1.1364 & 1.3453 & 1.3453 & 1.3453 & 0.000 & 5 & 35.00 & 16.00 & 0 & 25 \\
\hline 1 & 0.9200 & 1.0455 & 1.2534 & 0.8861 & 1.3453 & 16.384 & 5 & 31.00 & 16.00 & 1 & 23 \\
\hline *5 & 0.0000 & 0.0000 & 0.0045 & 0.0045 & 0.0045 & 0.000 & 5 & 15.00 & 16.00 & 0.0005 & 0.0005 \\
\hline 10 & 1.0000 & 1.1364 & 1.3453 & 1.3453 & 1.3453 & 0.000 & 5 & 35.00 & 16.00 & 0 & 25 \\
\hline 50 & 0.1600 & 0.1818 & 0.2214 & 0.0000 & 1.1071 & 223.607 & 5 & 16.50 & 16.00 & 1 & 4 \\
\hline \multirow{2}{*}{\multicolumn{7}{|c|}{$\begin{array}{l}\text { xiliary Tests } \\
\text { piro-Wilk's Test indicates non-normal distribution }(p<=0.01 \text { ) } \\
\text { tality of variance cannot be confirmed }\end{array}$}} & Statistic & & Critical & Skew & Kurt \\
\hline & & & & & & & 0.7349 & & 0.91 & 2.5671 & 12.57 \\
\hline \multirow{2}{*}{\multicolumn{3}{|c|}{$\begin{array}{l}\text { othesis Test (1-tail, 0.05) } \\
\text { Il's Many-One Rank Test }\end{array}$}} & NOEC & LOEC & ChV & TU & & & & & \\
\hline & & & 1 & 5 & 2.2361 & 100 & & & & & \\
\hline
\end{tabular}


Start Date:

End Date:

Sample Date:

Comments:
Test ID:

Lab ID:

Protocol: MBP 90-Anderson et al.
Sample 1D:

Sample Type:

Test Species:

\begin{tabular}{rccccc} 
Conc-\% & $\mathbf{1}$ & $\mathbf{2}$ & $\mathbf{3}$ & $\mathbf{4}$ & $\mathbf{5}$ \\
\hline B-Control & 1.0000 & 0.8000 & $\mathbf{0 . 8 0 0 0}$ & 0.8000 & 1.0000 \\
0.1 & 1.0000 & 0.8000 & 1.0000 & 0.8000 & 1.0000 \\
0.5 & 1.0000 & 1.0000 & 0.8000 & 1.0000 & 0.8000 \\
1 & 1.0000 & 0.8000 & 1.0000 & 1.0000 & 0.8000 \\
5 & 1.0000 & 1.0000 & 1.0000 & 1.0000 & 1.0000 \\
10 & 1.0000 & 0.8000 & 1.0000 & 1.0000 & 1.0000 \\
50 & 0.2000 & 0.4000 & 0.6000 & 0.6000 & 0.6000
\end{tabular}

\begin{tabular}{|c|c|c|c|c|c|c|c|c|c|}
\hline \multirow[b]{2}{*}{ Conc- $\%$} & \multirow[b]{2}{*}{ Mean } & \multirow[b]{2}{*}{ N-Mean } & \multicolumn{5}{|c|}{ Transform: Arcsin Square Root } & \multirow{2}{*}{$\begin{array}{l}\text { Rank } \\
\text { Sum }\end{array}$} & \multirow{2}{*}{$\begin{array}{l}\text { 1-Tailed } \\
\text { Critical }\end{array}$} \\
\hline & & & Mean & Min & $\operatorname{Max}$ & $\mathrm{CV} \%$ & $\mathbf{N}$ & & \\
\hline B-Control & 0.8800 & 1.0000 & 1.2024 & 1.1071 & 1.3453 & 10.848 & 5 & & \\
\hline 0.1 & 0.9200 & 1.0455 & 1.2500 & 1.1071 & 1.3453 & 10.434 & 5 & 30.00 & 16.00 \\
\hline 0.5 & 0.9200 & 1.0455 & 1.2500 & 1.1071 & 1.3453 & 10.434 & 5 & 30.00 & 16.00 \\
\hline 1 & 0.9200 & 1.0455 & 1.2500 & 1.1071 & 1.3453 & 10.434 & 5 & 30.00 & 16.00 \\
\hline 5 & 1.0000 & 1.1364 & 1.3453 & 1.3453 & 1.3453 & 0.000 & 5 & 35.00 & 16.00 \\
\hline 10 & 0.9600 & 1.0909 & 1.2977 & 1.1071 & 1.3453 & 8.207 & 5 & 32.50 & 16.00 \\
\hline${ }^{*} 50$ & 0.4800 & 0.5455 & 0.7613 & 0.4636 & 0.8861 & 24.676 & 5 & 15.00 & 16.00 \\
\hline
\end{tabular}

\begin{tabular}{|c|c|c|c|c|c|c|c|c|}
\hline Auxiliary Tests & & & & & Statistic & Critical & Skew & Kurt \\
\hline $\begin{array}{l}\text { Shapiro-Wilk's Test indicates n } \\
\text { Equality of variance cannot be }\end{array}$ & $\begin{array}{l}\text { ormal dis } \\
\text { rmed }\end{array}$ & ibution ( & $<=0.011$ & & 0.8884 & 0.91 & -0.676 & -0.5326 \\
\hline Hypothesis Test (1-tail, 0.05) & NOEC & LOEC & ChV & $\mathrm{TU}$ & & & & \\
\hline Steel's Many-One Rank Test & 10 & 50 & 22.361 & 10 & & & & \\
\hline
\end{tabular}




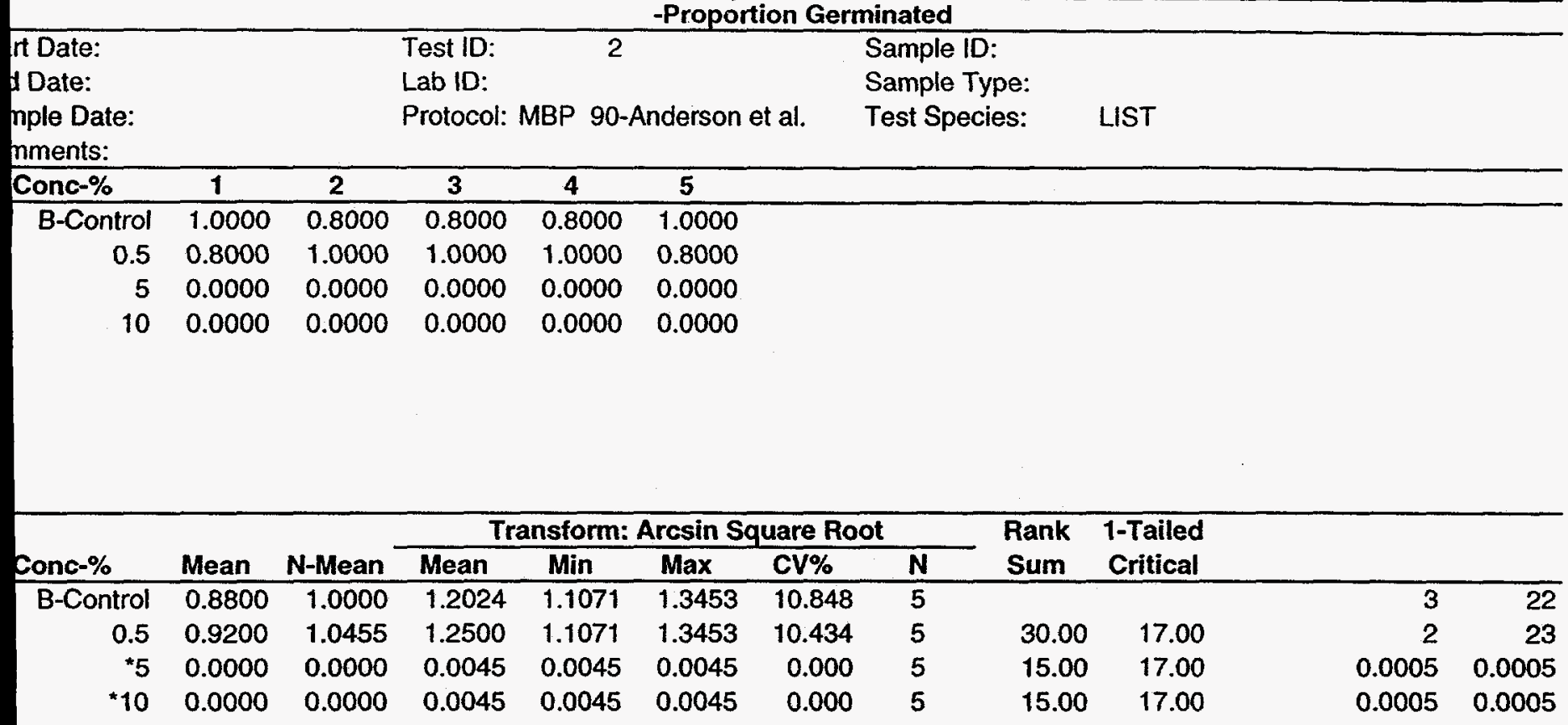

\begin{tabular}{|c|c|c|c|c|c|c|c|c|}
\hline \multirow{2}{*}{\multicolumn{5}{|c|}{$\begin{array}{l}\text { iliary Tests } \\
\text { piro-Wilk's Test indicates normal distribution }(p>0.01) \\
\text { ality of variance cannot be confirmed }\end{array}$}} & Statistic & Critical & Skew & $\begin{array}{c}\text { Kurt } \\
-0.4967\end{array}$ \\
\hline & & & & & 0.8885 & 0.868 & \#\#\#\#\#\#\# & -0.4967 \\
\hline othesis Test (1-tail, 0.05) & NOEC & LOEC & ChV & TU & & & & \\
\hline I's Many-One Rank Test & 0.5 & 5 & 1.5811 & 200 & & & & \\
\hline
\end{tabular}




\begin{tabular}{|c|c|c|c|c|c|c|c|}
\hline \multicolumn{8}{|c|}{-Proportion Germinated } \\
\hline \multirow{2}{*}{\multicolumn{3}{|c|}{$\begin{array}{l}\text { Start Date: } \\
\text { End Date: } \\
\text { Sample Date: } \\
\text { Comments: }\end{array}$}} & \multirow{2}{*}{$\begin{array}{l}\text { Test ID: } \\
\text { Lab ID: } \\
\text { Protocol: }\end{array}$} & \multicolumn{2}{|r|}{. } & \multirow{2}{*}{$\begin{array}{l}\text { Sample ID: } \\
\text { Sample Type: } \\
\text { Test Species: }\end{array}$} & \\
\hline & & & & ABP 90- & nderson et al. & & LIST \\
\hline Conc- $\%$ & 1 & 2 & 3 & 4 & 5 & & \\
\hline B-Control & 1.0000 & 0.8000 & 0.8000 & 0.8000 & 1.0000 & & \\
\hline 0.1 & 1.0000 & 0.8000 & 1.0000 & 1.0000 & 1.0000 & & \\
\hline 0.5 & 1.0000 & 0.8000 & 1.0000 & 0.8000 & 1.0000 & & \\
\hline 1 & 1.0000 & 1.0000 & 1.0000 & 1.0000 & 1.0000 & & \\
\hline 5 & 1.0000 & 1.0000 & 1.0000 & 1.0000 & 1.0000 & & \\
\hline 10 & 1.0000 & 1.0000 & 0.8000 & 1.0000 & 1.0000 & & \\
\hline 50 & 0.6000 & 0.2000 & 0.4000 & 0.8000 & 0.6000 & & \\
\hline
\end{tabular}

\begin{tabular}{|c|c|c|c|c|c|c|c|c|c|c|c|}
\hline \multirow[b]{2}{*}{ Conc-\% } & \multirow[b]{2}{*}{ Mean } & \multirow[b]{2}{*}{ N-Mean } & \multicolumn{5}{|c|}{ Transform: Arcsin Square Root } & \multirow{2}{*}{$\begin{array}{l}\text { Rank } \\
\text { Sum }\end{array}$} & \multirow{2}{*}{$\begin{array}{l}\text { 1-Tailed } \\
\text { Critical }\end{array}$} & & \\
\hline & & & Mean & Min & $\operatorname{Max}$ & CV\% & $\mathbf{N}$ & & & & \\
\hline B-Control & 0.8800 & 1.0000 & 1.2024 & 1.1071 & 1.3453 & 10.848 & 5 & & & 3 & 22 \\
\hline 0.1 & 0.9600 & 1.0909 & 1.2977 & 1.1071 & 1.3453 & 8.207 & 5 & 32.50 & 16.00 & 1 & 24 \\
\hline 0.5 & 0.9200 & 1.0455 & 1.2500 & 1.1071 & 1.3453 & 10.434 & 5 & 30.00 & 16.00 & 2 & 23 \\
\hline 1 & 1.0000 & 1.1364 & 1.3453 & 1.3453 & 1.3453 & 0.000 & 5 & 35.00 & 16.00 & 0 & 25 \\
\hline 5 & 1.0000 & 1.1364 & 1.3453 & 1.3453 & 1.3453 & 0.000 & 5 & 35.00 & 16.00 & 0 & 25 \\
\hline 10 & 0.9600 & 1.0909 & 1.2977 & 1.1071 & 1.3453 & 8.207 & 5 & 32.50 & 16.00 & 1 & 24 \\
\hline 50 & 0.5200 & 0.5909 & 0.8055 & 0.4636 & 1.1071 & 30.117 & 5 & 16.50 & 16.00 & 5 & 13 \\
\hline
\end{tabular}

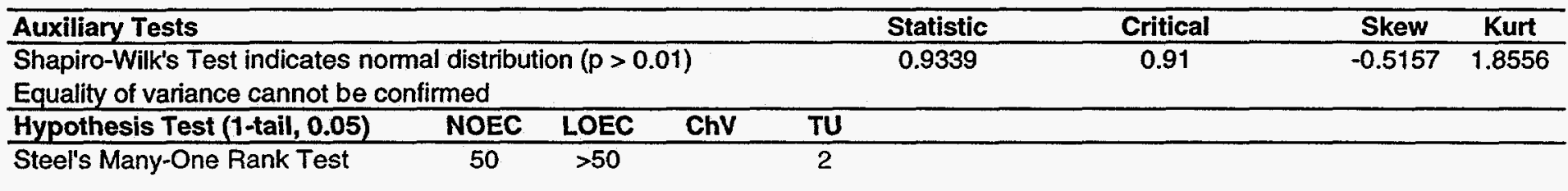




\begin{tabular}{|c|c|c|c|c|c|c|c|c|c|c|c|}
\hline \multicolumn{12}{|c|}{-Proportion Germinated } \\
\hline $\begin{array}{l}\text { Date: } \\
\text { Date: } \\
\text { ple Date: } \\
\text { ments: }\end{array}$ & \multirow[b]{2}{*}{1} & \multirow{2}{*}{\multicolumn{2}{|c|}{$\begin{array}{l}\text { Test ID: } \\
\text { Lab ID: } \\
\text { Protocol: } \\
3\end{array}$}} & \multicolumn{3}{|c|}{ MBP 90-Anderson et al. } & \multicolumn{2}{|c|}{$\begin{array}{l}\text { Sample ID: } \\
\text { Sample Type: } \\
\text { Test Species: }\end{array}$} & \multirow[t]{2}{*}{ LIST } & & \\
\hline Fonc-\% & & & & 4 & 5 & & & & & & \\
\hline B-Control & 1.0000 & 0.8000 & 0.8000 & 0.8000 & 1.0000 & & & & & & \\
\hline 0.1 & 1.0000 & 1.0000 & 1.0000 & 1.0000 & 1.0000 & & & & & & \\
\hline 0.5 & 0.8000 & 0.8000 & 1.0000 & 0.8000 & 1.0000 & & & & & & \\
\hline 1 & 1.0000 & 1.0000 & 1.0000 & 1.0000 & 1.0000 & & & & & & \\
\hline 5 & 0.0000 & 0.0000 & 0.0000 & 0.8000 & 0.0000 & & & & & & \\
\hline 10 & 0.4000 & 1.0000 & 0.6000 & 1.0000 & 1.0000 & & & & & & \\
\hline \multirow[b]{3}{*}{ onc-\% } & 0.0000 & 0.6000 & 0.0000 & 0.2000 & 0.0000 & & & & & & \\
\hline & & & \multicolumn{5}{|c|}{ Transform: Arcsin Square Root } & \multirow{2}{*}{$\begin{array}{l}\text { Rank } \\
\text { Sum }\end{array}$} & \multirow{2}{*}{$\begin{array}{l}\text { 1-Tailed } \\
\text { Critical }\end{array}$} & & \\
\hline & Mean & N-Mean & Mean & Min & Max & CV\% & $\mathbf{N}$ & & & & \\
\hline B-Control & 0.8800 & 1.0000 & 1.2024 & 1.1071 & 1.3453 & 10.848 & 5 & & & 3 & 22 \\
\hline 0.1 & 1.0000 & 1.1364 & 1.3453 & 1.3453 & 1.3453 & 0.000 & 5 & 35.00 & 16.00 & 0 & 25 \\
\hline 0.5 & 0.8800 & 1.0000 & 1.2024 & 1.1071 & 1.3453 & 10.848 & 5 & 27.50 & 16.00 & 3 & 22 \\
\hline 1 & 1.0000 & 1.1364 & 1.3453 & 1.3453 & 1.3453 & 0.000 & 5 & 35.00 & 16.00 & 0 & 25 \\
\hline 5 & 0.1600 & 0.1818 & 0.2214 & 0.0000 & 1.1071 & 223.607 & 5 & 16.50 & 16.00 & 1 & 4 \\
\hline 10 & 0.8000 & 0.9091 & 1.1213 & 0.6847 & 1.3453 & 28.075 & 5 & 27.00 & 16.00 & 2 & 20 \\
\hline *50 & 0.1600 & 0.1818 & 0.2699 & 0.0000 & 0.8861 & 147.686 & 5 & 15.00 & 16.00 & 2 & 4 \\
\hline \multicolumn{7}{|l|}{ liary Tests } & Statistic & & Critical & Skew & Kurt \\
\hline \multicolumn{7}{|c|}{$\begin{array}{l}\text { biro-Wilk's Test indicates non-normal distribution }(p<=0.01 \text { ) } \\
\text { ality of variance cannot be confirmed }\end{array}$} & 0.8751 & & 0.91 & 1.5264 & 4.0569 \\
\hline bthesis Tes & $t(1-$ tail), & $0.05)$ & NOEC & LOEC & ChV & TU & & & & & \\
\hline I's Many-On & e Rank T & est & 10 & 50 & 22.361 & 10 & & & & & \\
\hline
\end{tabular}




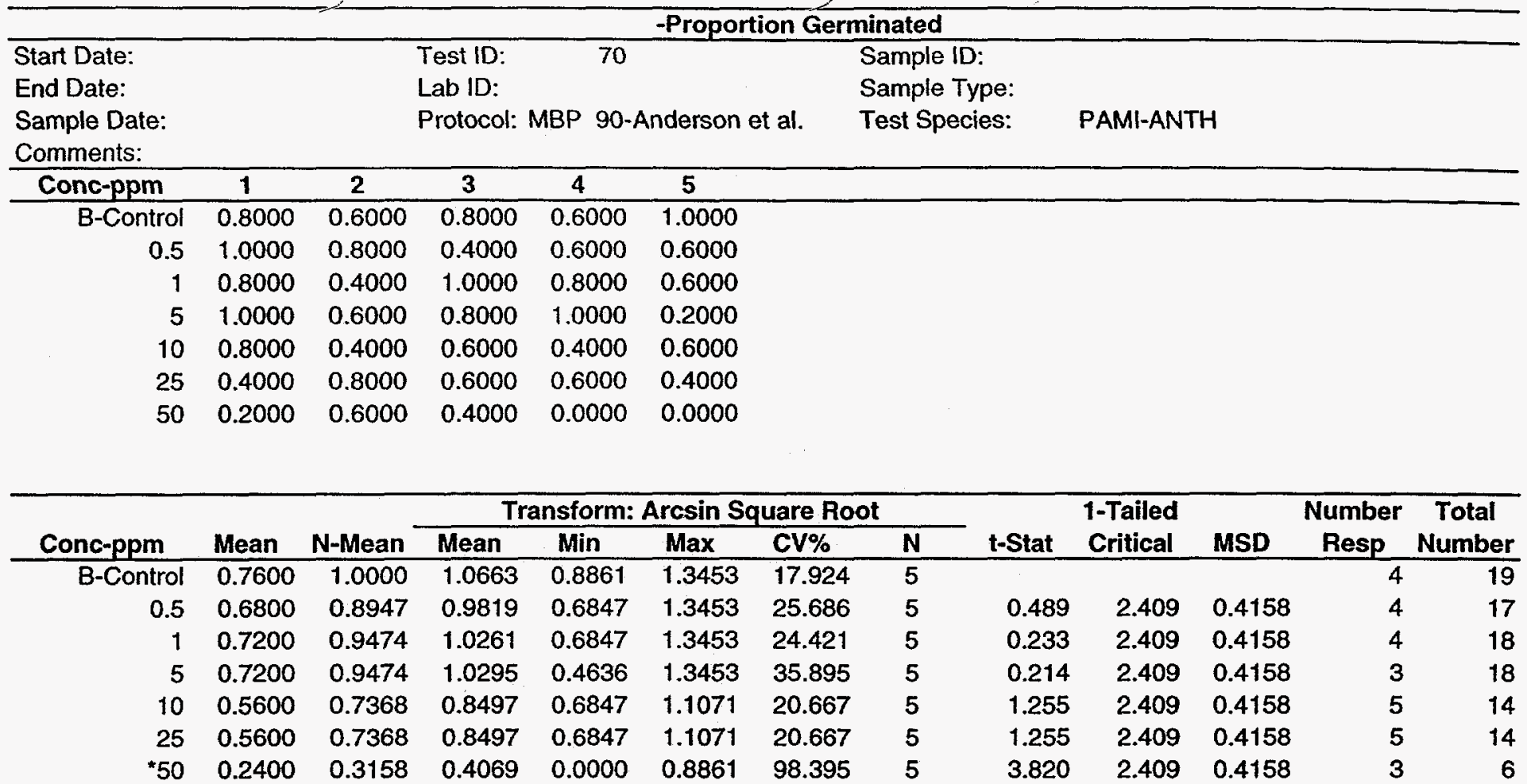

\begin{tabular}{|c|c|c|c|c|c|c|c|c|c|c|}
\hline & \multicolumn{2}{|l|}{ Statistic } & \multicolumn{2}{|l|}{ Critical } & \multirow{2}{*}{$\frac{\text { Skew }}{-0.1729}$} & Kurt \\
\hline Shapiro-Wilk's Test indicates $n$ & distribu & on $(p>0$ & & & 0.9674 & & 0.91 & & & -0.4271 \\
\hline Bartlett's Test indicates equal v & $\operatorname{ces}(p=$ & .51) & & & 5.2332 & & 16.812 & & & \\
\hline Hypothesis Test (1-tail, 0.05) & NOEC & LOEC & ChV & TU & MSDu & MSB & MSE & F-Stat & F-Prob & df \\
\hline Dunnett's Test & 25 & 50 & 35.355 & & 0.3996 & 0.2617 & 0.0745 & 3.5136 & 0.0102 & 6,28 \\
\hline
\end{tabular}

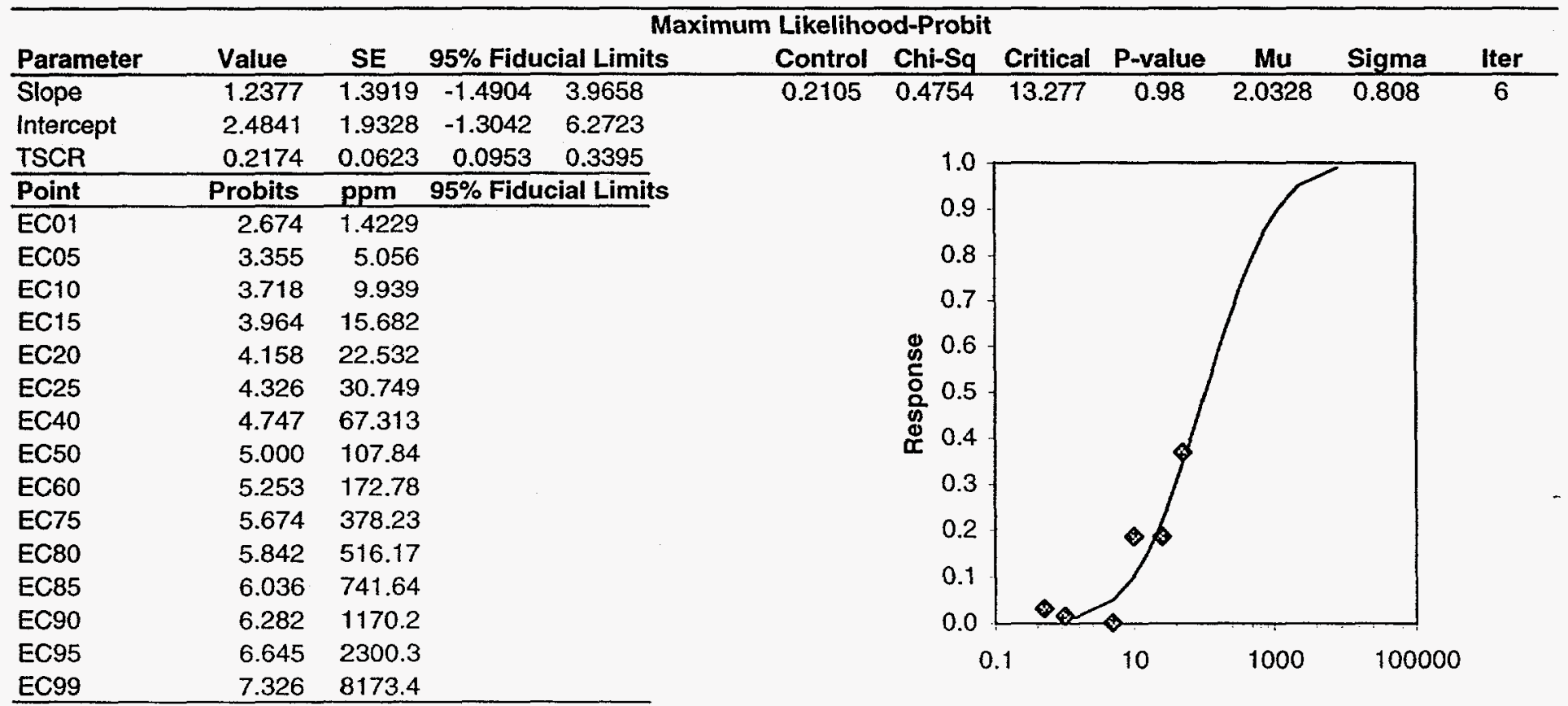

Dose ppm 


\begin{tabular}{|c|c|c|c|c|c|c|c|}
\hline \multicolumn{8}{|c|}{-Proportion Germinated } \\
\hline \multicolumn{3}{|l|}{$\begin{array}{l}\text { t Date: } \\
\text { Date: } \\
\text { iple Date: } \\
\text { iments: }\end{array}$} & $\begin{array}{l}\text { Test ID: } \\
\text { Lab ID: } \\
\text { Protocol: }\end{array}$ & \multicolumn{2}{|l|}{70} & \multirow[t]{2}{*}{$\begin{array}{l}\text { Sample ID: } \\
\text { Sample Type: } \\
\text { Test Species: }\end{array}$} & \multirow[t]{2}{*}{ PAMI-ATRA } \\
\hline onc-ppm & 1 & 2 & 3 & 4 & 5 & & \\
\hline B-Control & 0.8000 & 0.6000 & 0.8000 & 0.6000 & 1.0000 & & \\
\hline 0.5 & 0.8000 & 1.0000 & 1.0000 & 0.6000 & 0.8000 & & \\
\hline 1 & 0.4000 & 0.2000 & 1.0000 & 0.8000 & 0.8000 & & \\
\hline 5 & 0.6000 & 0.4000 & 0.8000 & 0.6000 & 0.4000 & & \\
\hline 10 & 0.8000 & 0.8000 & 0.4000 & 0.4000 & 0.6000 & & \\
\hline 25 & 1.0000 & 0.8000 & 0.6000 & 0.6000 & 0.4000 & & \\
\hline 50 & 0.4000 & 1.0000 & 0.4000 & 0.4000 & 0.8000 & & \\
\hline
\end{tabular}

\begin{tabular}{|c|c|c|c|c|c|c|c|c|c|c|c|c|}
\hline \multirow[b]{2}{*}{ enc-ppm } & \multirow[b]{2}{*}{ Mean } & \multirow[b]{2}{*}{ N-Mean } & \multicolumn{5}{|c|}{ Transform: Arcsin Square Root } & \multicolumn{3}{|c|}{ 1-Tailed } & \multirow{2}{*}{$\begin{array}{c}\text { Number } \\
\text { Resp }\end{array}$} & \multirow{2}{*}{$\begin{array}{c}\text { Total } \\
\text { Number }\end{array}$} \\
\hline & & & Mean & Min & Max & CV\% & $\mathbf{N}$ & t-Stat & Critical & MSD & & \\
\hline B-Control & 0.7600 & 1.0000 & 1.0663 & 0.8861 & 1.3453 & 17.924 & 5 & & & & 4 & 19 \\
\hline 0.5 & 0.8400 & 1.1053 & 1.1582 & 0.8861 & 1.3453 & 16.679 & 5 & -0.582 & 2.409 & 0.3802 & 3 & 21 \\
\hline 1 & 0.6400 & 0.8421 & 0.9416 & 0.4636 & 1.3453 & 38.004 & 5 & 0.790 & 2.409 & 0.3802 & 4 & 16 \\
\hline 5 & 0.5600 & 0.7368 & 0.8497 & 0.6847 & 1.1071 & 20.667 & 5 & 1.372 & 2.409 & 0.3802 & 5 & 14 \\
\hline 10 & 0.6000 & 0.7895 & 0.8940 & 0.6847 & 1.1071 & 23.632 & 5 & 1.092 & 2.409 & 0.3802 & 5 & 15 \\
\hline 25 & 0.6800 & 0.8947 & 0.9819 & 0.6847 & 1.3453 & 25.686 & 5 & 0.535 & 2.409 & 0.3802 & 4 & 17 \\
\hline 50 & 0.6000 & 0.7895 & 0.9013 & 0.6847 & 1.3453 & 34.206 & 5 & 1.045 & 2.409 & 0.3802 & 4 & 15 \\
\hline
\end{tabular}

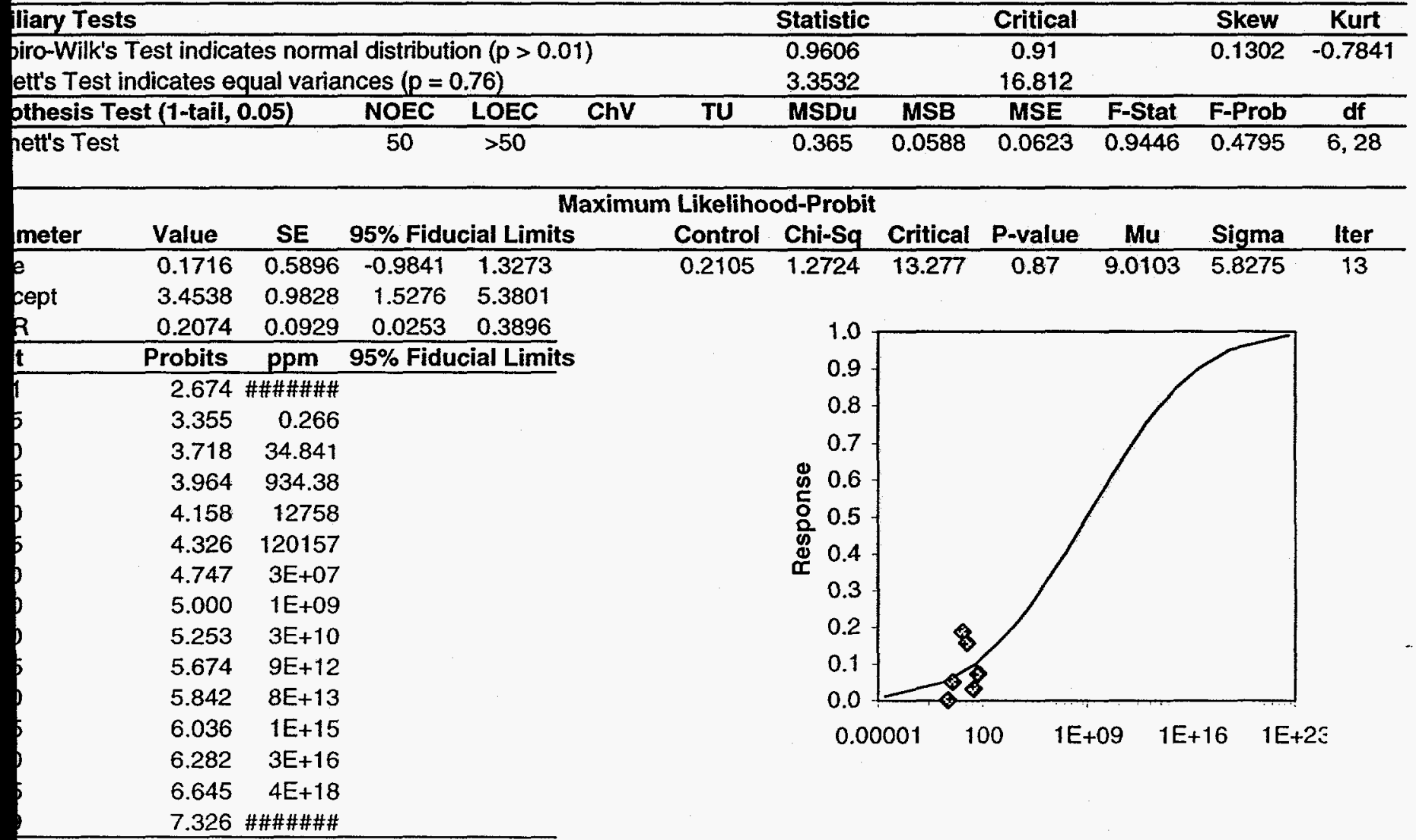

Dose ppm 




\begin{tabular}{|c|c|c|c|c|c|c|c|c|c|c|}
\hline Auxiliary Tests & & & & & Statistic & & Critical & & Skew & Kurt \\
\hline Shapiro-Wilk's Test indicates no & distribu & $n(p>0$ & & & 0.965 & & 0.91 & & -0.4973 & 0.4276 \\
\hline Bartlett's Test indicates equal v & $\operatorname{ces}\langle p=$ & .70) & & & 3.8146 & & 16.812 & & & \\
\hline Hypothesis Test (1-tail, 0.05$)$ & NOEC & LOEC & ChV & TU & MSDu & MSB & MSE & F-Stat & F-Prob & df \\
\hline Dunnett's Test & 25 & 50 & 35.355 & & 0.3541 & 0.1702 & 0.0587 & 2.8995 & 0.0251 & 6,28 \\
\hline
\end{tabular}

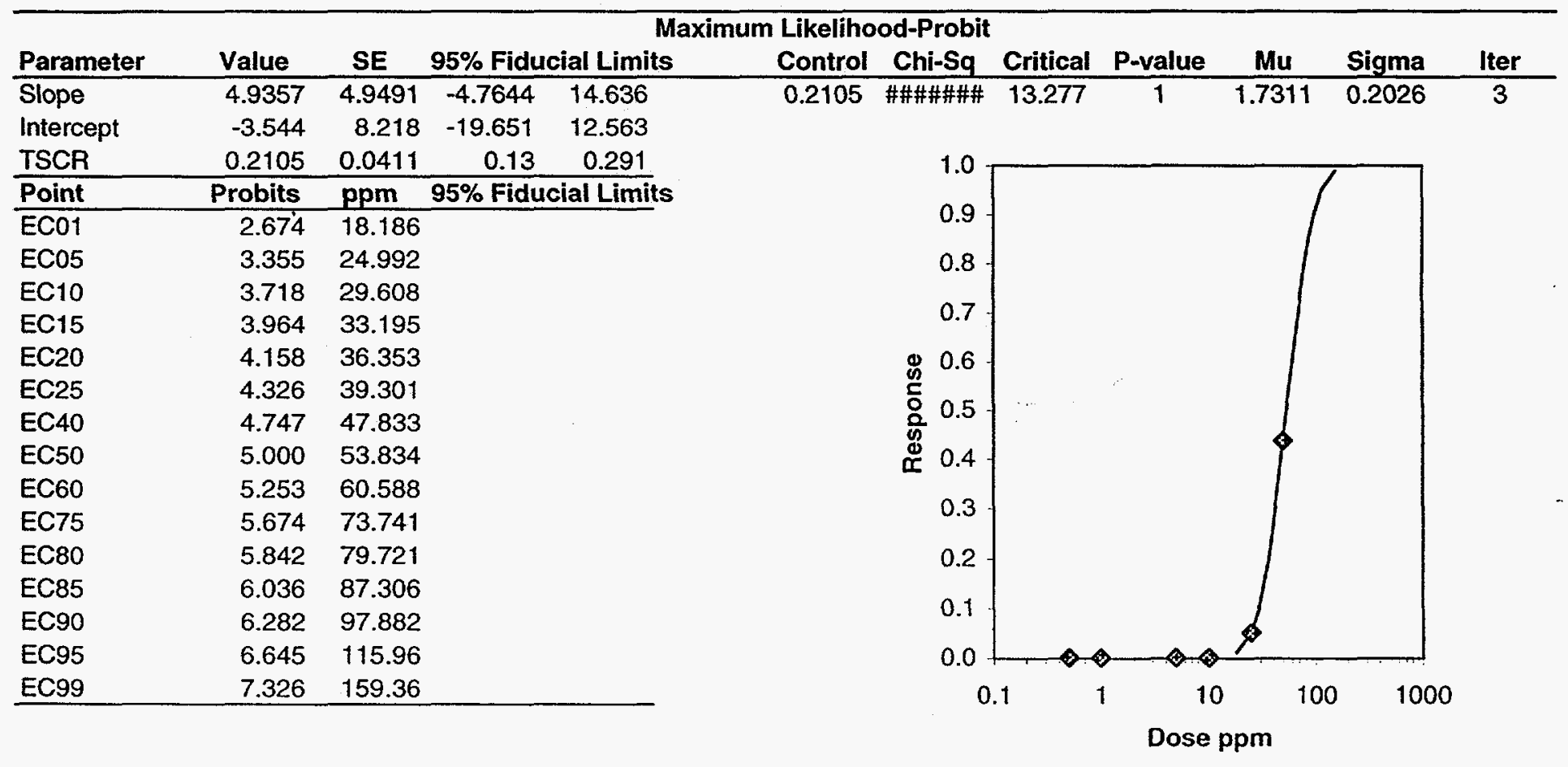


Date:

Date:

ple Date:

iments:

\begin{tabular}{|c|c|c|c|c|c|}
\hline nnc-ppm & 1 & 2 & 3 & 4 & 5 \\
\hline B-Control & 0.8000 & 0.6000 & 0.8000 & 0.6000 & 1.0000 \\
\hline 0.1 & 1.0000 & 1.0000 & 1.0000 & 0.6000 & 0.6000 \\
\hline 0.2 & 0.8000 & 0.8000 & 0.6000 & 0.4000 & 0.4000 \\
\hline 0.5 & 1.0000 & 0.6000 & 0.8000 & 0.2000 & 0.6000 \\
\hline 1 & 0.6000 & 0.2000 & 0.6000 & 1.0000 & 0.6000 \\
\hline 2.5 & 0.4000 & 0.6000 & 0.4000 & 1.0000 & 0.4000 \\
\hline 5 & 0.2000 & 0.0000 & 0.0000 & 0.0000 & 0.0000 \\
\hline
\end{tabular}

-Proportion Germinated

Test ID: $\quad 70 \quad$ Sample ID:

Lab ID: $\quad$ Sample Type:

Protocol: MBP 90-Anderson et al. Test Species:

\begin{tabular}{|c|c|c|c|c|c|c|c|c|c|c|c|c|}
\hline \multirow[b]{2}{*}{ nnc-ppm } & \multirow[b]{2}{*}{ Mean } & \multirow[b]{2}{*}{ N-Mean } & \multicolumn{5}{|c|}{ Transform: Arcsin Square Root } & \multicolumn{3}{|c|}{ 1-Tailed } & \multirow{2}{*}{$\begin{array}{c}\text { Number } \\
\text { Resp }\end{array}$} & \multirow{2}{*}{$\begin{array}{c}\text { Total } \\
\text { Number }\end{array}$} \\
\hline & & & Mean & Min & Max & CV\% & $\mathbf{N}$ & t-Stat & Critical & MSD & & \\
\hline B-Control & 0.7600 & 1.0000 & 1.0663 & 0.8861 & 1.3453 & 17.924 & 5 & & & & 4 & 19 \\
\hline 0.1 & 0.8400 & 1.1053 & 1.1616 & 0.8861 & 1.3453 & 21.653 & 5 & -0.579 & 2.409 & 0.3960 & 2 & 21 \\
\hline 0.2 & 0.6000 & 0.7895 & 0.8940 & 0.6847 & 1.1071 & 23.632 & 5 & 1.049 & 2.409 & 0.3960 & 5 & 15 \\
\hline 0.5 & 0.6400 & 0.8421 & 0.9376 & 0.4636 & 1.3453 & 34.759 & 5 & 0.783 & 2.409 & 0.3960 & 4 & 16 \\
\hline 1 & 0.6000 & 0.7895 & 0.8934 & 0.4636 & 1.3453 & 34.907 & 5 & 1.052 & 2.409 & 0.3960 & 4 & 15 \\
\hline 2.5 & 0.5600 & 0.7368 & 0.8571 & 0.6847 & 1.3453 & 33.425 & 5 & 1.273 & 2.409 & 0.3960 & 4 & 14 \\
\hline${ }^{*} 5$ & 0.0400 & 0.0526 & 0.0927 & 0.0000 & 0.4636 & 223.607 & 5 & 5.922 & 2.409 & 0.3960 & 1 & 7 \\
\hline
\end{tabular}

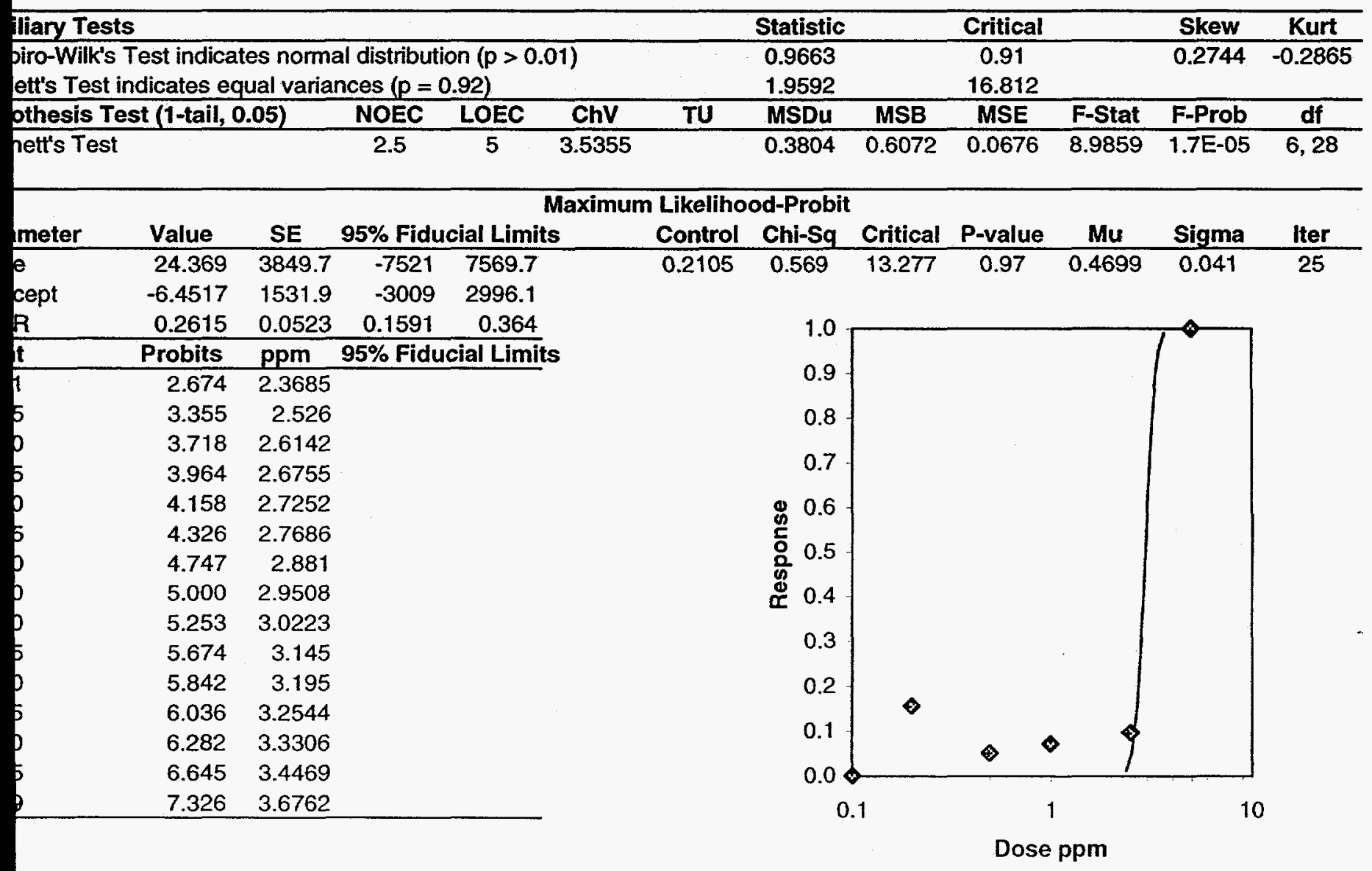




\begin{tabular}{|c|c|c|c|c|c|c|c|}
\hline \multicolumn{8}{|c|}{-Proportion Germinated } \\
\hline $\begin{array}{l}\text { Start Date: } \\
\text { End Date: } \\
\text { Sample Date: } \\
\text { Comments: }\end{array}$ & & & $\begin{array}{l}\text { Test ID: } \\
\text { Lab ID: } \\
\text { Protocol: }\end{array}$ & $\begin{array}{r}11 \\
\text { MBP } 90-\end{array}$ & Anderson et al. & $\begin{array}{l}\text { Sample ID: } \\
\text { Sample Type: } \\
\text { Test Species: }\end{array}$ & PAMI-NI \\
\hline Conc-ppm & 1 & 2 & 3 & 4 & 5 & & \\
\hline B-Control & 0.8000 & 0.6000 & 0.8000 & 0.6000 & 1.0000 & & \\
\hline 0.5 & 0.8000 & 1.0000 & 1.0000 & 1.0000 & 1.0000 & & \\
\hline 1 & 0.8000 & 0.6000 & 0.8000 & 0.8000 & 0.8000 & & \\
\hline 5 & 0.4000 & 0.4000 & 1.0000 & 0.8000 & 1.0000 & & \\
\hline 10 & 0.8000 & 0.6000 & 0.8000 & 0.6000 & 0.4000 & & \\
\hline 25 & 1.0000 & 0.6000 & 0.6000 & 0.8000 & 0.8000 & & \\
\hline 50 & 0.6000 & 0.6000 & 0.8000 & 0.8000 & 0.2000 & & \\
\hline
\end{tabular}

\begin{tabular}{|c|c|c|c|c|c|c|c|c|c|c|c|c|}
\hline \multirow[b]{2}{*}{ Conc-ppm } & \multirow[b]{2}{*}{ Mean } & \multirow[b]{2}{*}{ N-Mean } & \multicolumn{5}{|c|}{ Transform: Arcsin Square Root } & \multicolumn{3}{|c|}{ 1-Tailed } & \multirow{2}{*}{$\begin{array}{l}\text { Number } \\
\text { Resp }\end{array}$} & \multirow{2}{*}{$\begin{array}{c}\text { Total } \\
\text { Number }\end{array}$} \\
\hline & & & Mean & Min & Max & CV\% & $\overline{\mathbf{N}}$ & t-Stat & Critical & MSD & & \\
\hline B-Control & 0.7600 & 1.0000 & 1.0663 & 0.8861 & 1.3453 & 17.924 & 5 & & & & 4 & $\overline{19}$ \\
\hline 0.5 & 0.9600 & 1.2632 & 1.2977 & 1.1071 & 1.3453 & 8.207 & 5 & -1.750 & 2.409 & 0.3183 & 1 & 24 \\
\hline 1 & 0.7600 & 1.0000 & 1.0629 & 0.8861 & 1.1071 & 9.301 & 5 & 0.026 & 2.409 & 0.3183 & 5 & 19 \\
\hline 5 & 0.7200 & 0.9474 & 1.0334 & 0.6847 & 1.3453 & 32.208 & 5 & 0.249 & 2.409 & 0.3183 & 3 & 18 \\
\hline 10 & 0.6400 & 0.8421 & 0.9342 & 0.6847 & 1.1071 & 19.050 & 5 & 1.000 & 2.409 & 0.3183 & 5 & 16 \\
\hline 25 & 0.7600 & 1.0000 & 1.0663 & 0.8861 & 1.3453 & 17.924 & 5 & 0.000 & 2.409 & 0.3183 & 4 & 19 \\
\hline 50 & 0.6000 & 0.7895 & 0.8900 & 0.4636 & 1.1071 & 29.520 & 5 & 1.334 & 2.409 & 0.3183 & 5 & 15 \\
\hline
\end{tabular}

\begin{tabular}{|c|c|c|c|c|c|c|c|c|c|c|}
\hline \multicolumn{5}{|l|}{ Auxiliary Tests } & \multicolumn{2}{|l|}{ Statistic } & \multicolumn{2}{|l|}{ Critical } & \multirow{2}{*}{ Skew } & Kurt \\
\hline Shapiro-Wilk's Test indicates $n$ & distribu & $n(p>0$ & & & 0.9363 & & 0.91 & & & -0.2892 \\
\hline Bartlett's Test indicates equal v & $\operatorname{ces}(p=$ & .25) & & & 7.7933 & & 16.812 & & & \\
\hline Hypothesis Test (1-tail, 0.05$)$ & NOEC & LOEC & ChV & TU & MSDu & MSB & MSE & F-Stat & F-Prob & df \\
\hline Dunnett's Test & 50 & $>50$ & & & 0.3037 & 0.0844 & 0.0437 & 1.9333 & 0.1102 & 6,28 \\
\hline
\end{tabular}

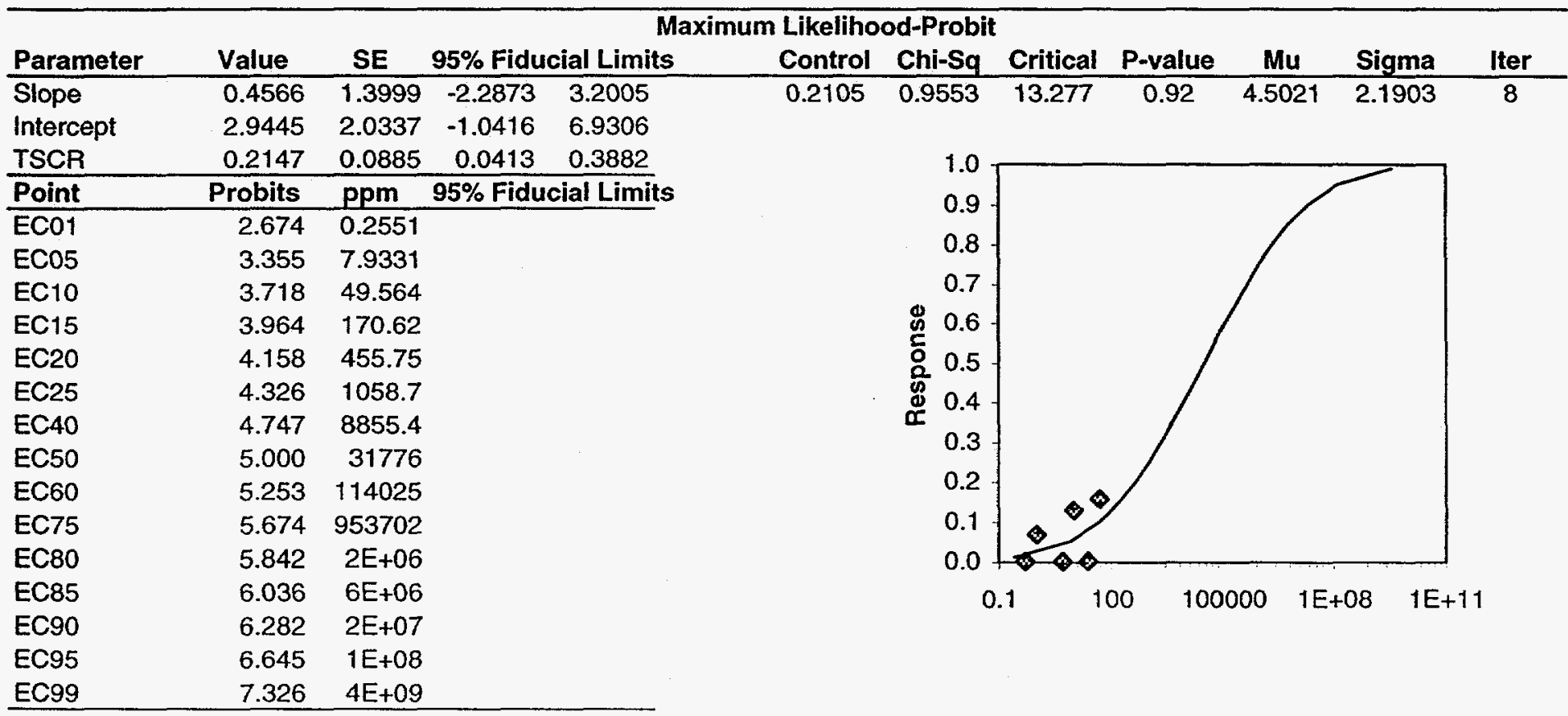

Dose ppm 


\section{-Proportion Germinated}

t Date:

Date:

iple Date:

iments:
Test ID:

Lab ID:

Protocol: MBP 90-Anderson et al.

\section{Sample ID:}

Sample Type:

Test Species:

\begin{tabular}{|c|c|c|c|c|c|}
\hline c-ppm & 1 & 2 & 3 & 4 & 5 \\
\hline 1 & 0.8000 & 0.6000 & 0.8000 & 0.6000 & 1.0000 \\
\hline 0.5 & 0.6000 & 1.0000 & 0.6000 & 0.8000 & 1.0000 \\
\hline 1 & 0.8000 & 0.8000 & 0.8000 & 0.6000 & 0.6000 \\
\hline 5 & 0.2000 & 0.8000 & 1.0000 & 0.6000 & 0.8000 \\
\hline 10 & 1.0000 & 0.8000 & 0.8000 & 0.2000 & 1.0000 \\
\hline 25 & 0.8000 & 1.0000 & 0.4 & 0.6000 & 0.600 \\
\hline - & 0.8000 & 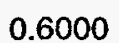 & 1.0000 & & \\
\hline
\end{tabular}

\begin{tabular}{|c|c|c|c|c|c|c|c|c|c|c|c|c|}
\hline \multirow[b]{2}{*}{ onc-ppm } & \multirow[b]{2}{*}{ Mean } & \multirow[b]{2}{*}{ Mean } & \multicolumn{5}{|c|}{ Transform: Arcsin Square Root } & \multicolumn{3}{|c|}{ 1-Tailed } & \multirow{2}{*}{$\begin{array}{c}\text { Number } \\
\text { Resp }\end{array}$} & \multirow{2}{*}{$\begin{array}{c}\text { Total } \\
\text { Number }\end{array}$} \\
\hline & & & Mean & Min & Max & CV\% & $\mathbf{N}$ & t-Stat & Critical & MSD & & \\
\hline B-Control & 0.7600 & 1.0000 & 1.0663 & 0.8861 & 1.3453 & 17.924 & 5 & & & & 4 & $\overline{19}$ \\
\hline 0.5 & 0.8000 & 1.0526 & 1.1140 & 0.8861 & 1.3453 & 20.614 & 5 & -0.284 & 2.409 & 0.4039 & 3 & 20 \\
\hline 1 & 0.7200 & 0.9474 & 1.0187 & 0.8861 & 1.1071 & 11.886 & 5 & 0.284 & 2.409 & 0.4039 & 5 & 18 \\
\hline 5 & 0.6800 & 0.8947 & 0.9819 & 0.4636 & 1.3453 & 33.825 & 5 & 0.504 & 2.409 & 0.4039 & 4 & 17 \\
\hline 10 & 0.7600 & 1.0000 & 1.0737 & 0.4636 & 1.3453 & 33.642 & 5 & -0.044 & 2.409 & 0.4039 & 3 & 19 \\
\hline 25 & 0.6800 & 0.8947 & 0.9819 & 0.6847 & 1.3453 & 25.686 & $\mathbf{5}$ & 0.504 & 2.409 & 0.4039 & 4 & 17 \\
\hline 50 & 0.7600 & 1.0000 & 1.0737 & 0.6847 & 1.3453 & 26.959 & 5 & -0.044 & 2.409 & 0.4039 & 3 & 19 \\
\hline
\end{tabular}

\begin{tabular}{|c|c|c|c|c|c|c|c|c|c|c|c|c|}
\hline \multirow{2}{*}{\multicolumn{7}{|c|}{$\begin{array}{l}\text { liary Tests } \\
\text { iro-Wilk's Test indicates normal distribution }(p>0.01)\end{array}$}} & \multirow{2}{*}{$\frac{\text { Statistic }}{0.9512}$} & \multicolumn{2}{|r|}{ Critical } & & Skew & \multirow{3}{*}{$\frac{\text { Kurt }}{0.0696}$} \\
\hline & & & & & & & & & 0.91 & & -0.6042 & \\
\hline & & & & & & & 4.9863 & & 16.812 & & & \\
\hline \multicolumn{3}{|c|}{ othesis Test (1-tail, 0.05$)$} & NOEC & LOEC & $\overline{\mathrm{ChV}}$ & TU & MSDu & MSB & MSE & F-Stat & F-Prob & df \\
\hline \multicolumn{3}{|l|}{ pett's Test } & 50 & $>50$ & & & 0.3881 & 0.0129 & 0.0703 & 0.184 & 0.9789 & 6,28 \\
\hline \multicolumn{13}{|c|}{ Maximum Likelihood-Probit } \\
\hline meter & Value & SE & $95 \%$ Fidu & jial Limits & & Control & Chi-Sq & Critical & P-value & Mu & Sigma & Iter \\
\hline$r$ & -0.1871 & 1.4558 & -3.0404 & 2.6662 & & 0.2105 & 0.3472 & 13.277 & 0.99 & -9.8349 & -5.3445 & 7 \\
\hline cept & 3.1598 & 2.1142 & -0.9839 & 7.3035 & & & & & & & & \\
\hline B & 0.2088 & 0.093 & 0.0265 & 0.3911 & & & & & 1.0 & & & \\
\hline 5 & Probits & ppm & $95 \%$ Fidu & ial Limits & & & & & 09 & & & \\
\hline & 2.674 & 396.49 & & & & & & & 0.0 & & & \\
\hline & 3.355 & 0.0904 & & & & & & & & & & \\
\hline & 3.718 & 0.001 & & & & & & & 0.7 & & & \\
\hline & 3.964 & \#\#\#\#\#\#\# & & & & & 禺 & & 26 & & & \\
\hline & 4.158 & \#\#\#\#\#\#\# & & & & & : & & 0.5 & & & \\
\hline & 4.326 & \#\#\#\#\#\#\# & & & & & $\bar{g}$ & & 0.4 & & & \\
\hline & 4.747 & \#\#\#\#\#\#\# & & & & & & & 03 & & & \\
\hline & 5.000 & \#\#\#\#\#\#\# & & & & & & & & & & \\
\hline & 5.253 & \#\#\#\#\#\#\# & & & & & & & 0.2 & & & \\
\hline & 5.674 & \#\#\#\#\#\#\# & & & & & & & 0.1 & & & \\
\hline & $5.842 \ddagger$ & \#\#\#\#\#\#\# & & & & & & & -0.0 & & 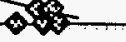 & \\
\hline & 6.036 & \#\#\#\#\#\# & & & & & $1 E-23$ & $1 E-16$ & $1 \mathrm{E}-09$ & 0.0 & 100 & \\
\hline & 6.282 & \#\#\#\#\#\#\# & & & & & & & & & & \\
\hline & 6.645 & \#\#\#\#\#\#\# & & & & & & & & & & \\
\hline & & \#\#\#\#\# & & & & & & & & & & \\
\hline
\end{tabular}

Dose ppm 


\begin{tabular}{|c|c|c|c|c|c|c|c|c|c|c|c|}
\hline \multicolumn{12}{|c|}{-Proportion Germinated } \\
\hline $\begin{array}{l}\text { Start Date: } \\
\text { End Date: } \\
\text { Sample Date: } \\
\text { Comments: } \\
\end{array}$ & & & $\begin{array}{l}\text { Test ID: } \\
\text { Lab ID: } \\
\text { Protocol: }\end{array}$ & $\begin{array}{r}2 \\
\text { MBP } 90-A\end{array}$ & nderson & t al. & $\begin{array}{l}\text { Sample ID: } \\
\text { Sample Ty } \\
\text { Test Speci }\end{array}$ & & QUFA & & \\
\hline Conc-ppm & 1 & 2 & 3 & 4 & 5 & & & & & & \\
\hline B-Control & 0.2000 & 0.2000 & 0.0000 & 0.0000 & 0.2000 & & & & & & \\
\hline 0.1 & 0.6000 & 0.2000 & 0.0000 & 0.2000 & 0.4000 & & & & & & \\
\hline 0.5 & 0.6000 & 0.2000 & 0.4000 & 0.0000 & 0.6000 & & & & & & \\
\hline 1 & 0.2000 & 0.4000 & 0.0000 & 0.2000 & 0.4000 & & & & & & \\
\hline 5 & 0.2000 & 0.2000 & 0.2000 & 0.6000 & 0.0000 & & & & & & \\
\hline 10 & 0.2000 & 0.6000 & 0.4000 & 0.4000 & 0.0000 & & & & & & \\
\hline \multirow[t]{2}{*}{50} & 0.0000 & 0.0000 & 0.0000 & 0.0000 & 0.0000 & & & & & & \\
\hline & & & \multicolumn{5}{|c|}{ Transform: Arcsin Square Root } & \multirow{2}{*}{$\begin{array}{l}\text { Rank } \\
\text { Sum }\end{array}$} & \multirow{2}{*}{$\begin{array}{l}\text { 1-Tailed } \\
\text { Critical }\end{array}$} & & \\
\hline Conc-ppm & Mean & N-Mean & Mean & Min & Max & $\mathrm{CV} \%$ & $\mathbf{N}$ & & & & \\
\hline B-Control & 0.1200 & 1.0000 & 0.2782 & 0.0000 & 0.4636 & 91.287 & 5 & & & 3 & 3 \\
\hline 0.1 & 0.2800 & 2.3333 & 0.4996 & 0.0000 & 0.8861 & 66.067 & 5 & 33.00 & 16.00 & 4 & 7 \\
\hline 0.5 & 0.3600 & 3.0000 & 0.5841 & 0.0000 & 0.8861 & 63.379 & 5 & 34.50 & 16.00 & 4 & 9 \\
\hline 1 & 0.2400 & 2.0000 & 0.4593 & 0.0000 & 0.6847 & 60.861 & 5 & 33.00 & 16.00 & 4 & 6 \\
\hline 5 & 0.2400 & 2.0000 & 0.4554 & 0.0000 & 0.8861 & 68.835 & 5 & 31.50 & 16.00 & 4 & 6 \\
\hline 10 & 0.3200 & 2.6667 & 0.5438 & 0.0000 & 0.8861 & 62.290 & 5 & 34.50 & 16.00 & 4 & 8 \\
\hline 50 & 0.0000 & 0.0002 & 0.0045 & 0.0045 & 0.0045 & 0.000 & 5 & 25.00 & 16.00 & 0.0005 & 0.0005 \\
\hline \multicolumn{7}{|l|}{ Auxiliary Tests } & Statistic & & Critical & Skew & Kurt \\
\hline \multicolumn{7}{|c|}{$\begin{array}{l}\text { Shapiro-Wilk's Test indicates normal distribution }(p>0.01) \\
\text { Equality of variance cannot be confirmed }\end{array}$} & 0.9157 & & 0.91 & -0.7187 & -0.0358 \\
\hline Hypothesis Te & (1-tail, & $0.05)$ & NOEC & LOEC & ChV & TU & & & & & \\
\hline Steel's Many-Or & e Rank T & est & 50 & $>50$ & & & & & & & \\
\hline
\end{tabular}




\begin{tabular}{|c|c|c|c|c|c|c|c|c|c|c|c|c|}
\hline \multicolumn{13}{|c|}{-Proportion Germinated } \\
\hline \multirow[t]{2}{*}{$\begin{array}{l}\text { Date: } \\
\text { Date: } \\
\text { nple Date: } \\
\text { nments: } \\
\text { onc-npm }\end{array}$} & \multirow[b]{2}{*}{1} & \multirow{2}{*}{\multicolumn{2}{|c|}{$\begin{array}{l}\text { Test ID: } \\
\text { Lab ID: } \\
\text { Protocol: } \\
\mathbf{3}\end{array}$}} & \multirow[t]{2}{*}{9} & \multicolumn{2}{|c|}{ Anderson et al. } & \multicolumn{2}{|c|}{$\begin{array}{l}\text { Sample ID: } \\
\text { Sample Type: } \\
\text { Test Species: }\end{array}$} & \multirow{2}{*}{\multicolumn{2}{|c|}{ QUFA }} & & \\
\hline & & & & & 5 & & & & & & & \\
\hline B-Control & 0.2000 & 0.2000 & 0.0000 & 0.0000 & 0.2000 & & & & & & & \\
\hline 0.1 & 0.0000 & 0.4000 & 0.0000 & 0.2000 & 0.2000 & & & & & & & \\
\hline 0.5 & 0.4000 & 0.0000 & 0.4000 & 0.2000 & 0.2000 & & & & & & & \\
\hline 1 & 0.2000 & 0.0000 & 0.4000 & 0.4000 & 0.0000 & & & & & & & \\
\hline 5 & 0.4000 & 0.6000 & 0.2000 & 0.0000 & 0.0000 & & & & & & & \\
\hline 10 & 0.2000 & 0.4000 & 0.6000 & 0.2000 & 0.6000 & & & & & & & \\
\hline \multirow[t]{2}{*}{50} & 0.6000 & 0.4000 & 0.4000 & 0.4000 & 0.2000 & & & & & & & \\
\hline & \multirow[b]{2}{*}{ Mean } & & \multicolumn{5}{|c|}{ Transform: Arcsin Square Root } & \multicolumn{3}{|c|}{ 1-Tailed } & Number & Total \\
\hline pnc-ppm & & N-Mean & Mean & Min & Max & $\mathrm{CV} \%$ & $\mathbf{N}$ & t-Stat & Critical & MSD & Resp & Number \\
\hline B-Control & 0.1200 & 1.0000 & 0.2782 & 0.0000 & 0.4636 & 91.287 & 5 & & & & 3 & 3 \\
\hline 0.1 & 0.1600 & 1.3333 & 0.3224 & 0.0000 & 0.6847 & 95.483 & 5 & -0.242 & 2.409 & 0.4403 & 3 & 4 \\
\hline 0.5 & 0.2400 & 2.0000 & 0.4593 & 0.0000 & 0.6847 & 60.861 & 5 & -0.991 & 2.409 & 0.4403 & 4 & 6 \\
\hline 1 & 0.2000 & 1.6667 & 0.3666 & 0.0000 & 0.6847 & 94.548 & 5 & -0.484 & 2.409 & 0.4403 & 3 & 5 \\
\hline 5 & 0.2400 & 2.0000 & 0.4069 & 0.0000 & 0.8861 & 98.395 & 5 & -0.704 & 2.409 & 0.4403 & 3 & 6 \\
\hline 10 & 0.4000 & 3.3333 & 0.6768 & 0.4636 & 0.8861 & 31.213 & 5 & -2.181 & 2.409 & 0.4403 & 5 & 10 \\
\hline 50 & 0.4000 & 3.3333 & 0.6808 & 0.4636 & 0.8861 & 21.953 & 5 & -2.202 & 2.409 & 0.4403 & 5 & 10 \\
\hline \multicolumn{7}{|l|}{ liary Tests } & Statistic & & Critical & & Skew & Kurt \\
\hline \multirow{2}{*}{\multicolumn{7}{|c|}{$\begin{array}{l}\text { biro-Wilk's Test indicates normal distribution }(p>0.01) \\
\text { ett's Test indicates equal variances }(p=0.66)\end{array}$}} & 0.926 & & 0.91 & & -0.2606 & -1.1563 \\
\hline & & & & & & & 4.1298 & & 16.812 & & & \\
\hline \multicolumn{3}{|c|}{ bthesis Test (1-tail, 0.05) } & NOEC & LOEC & ChV & TU & MSDu & MSB & MSE & F-Stat & F-Prob & df \\
\hline \multicolumn{3}{|l|}{ hett's Test } & 50 & $>50$ & & & 0.0494 & 0.1326 & 0.0835 & 1.5877 & 0.1877 & 6,28 \\
\hline meter & Value & SE & $95 \%$ Fidu & sial Limit & & Control & Chi-Sq & Critical & P-value & Mu & Sigma & Iter \\
\hline
\end{tabular}

t $\quad$ Probits $\quad$ ppm 95\% Fiducial Limits

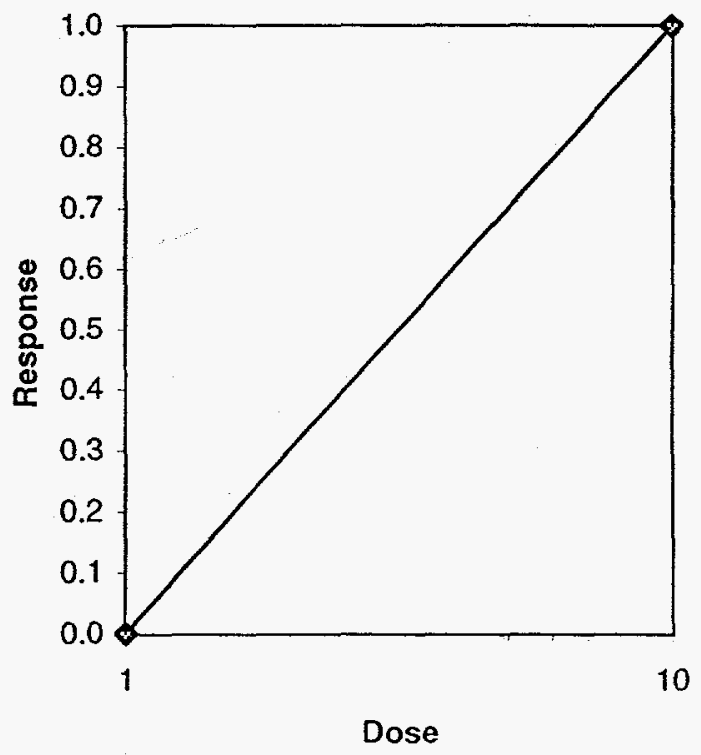




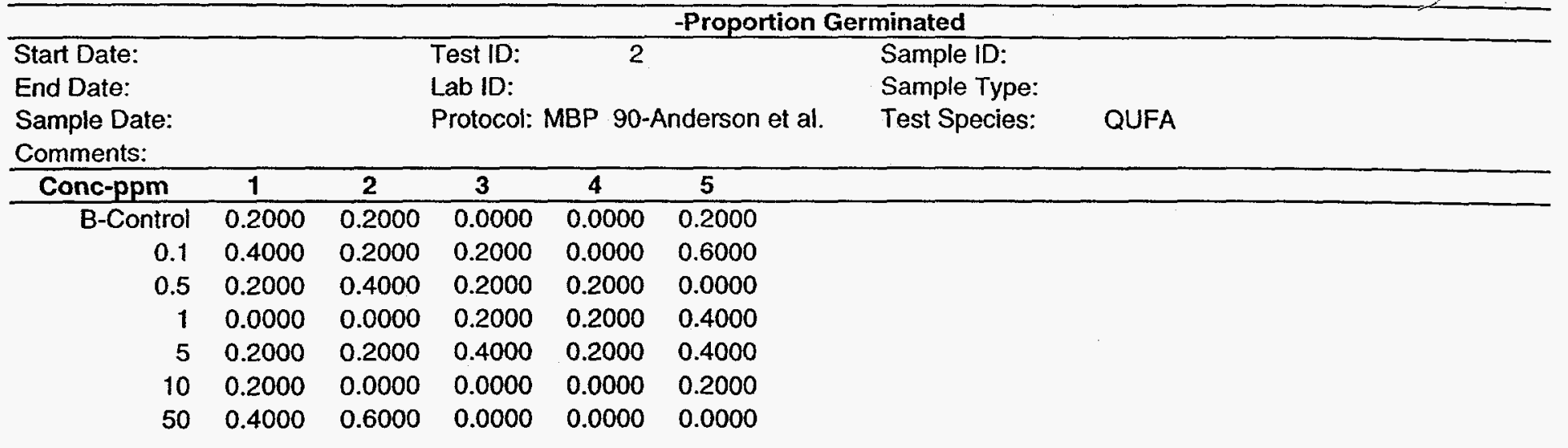

\begin{tabular}{|c|c|c|c|c|c|c|c|c|c|c|c|c|}
\hline \multirow[b]{2}{*}{ Conc-ppm } & \multirow[b]{2}{*}{ Mean } & \multirow[b]{2}{*}{ N-Mean } & \multicolumn{5}{|c|}{ Transform: Arcsin Square Root } & \multicolumn{3}{|c|}{ 1-Tailed } & & \\
\hline & & & Mean & Min & Max & CV\% & $\mathbf{N}$ & t-Stat & Critical & MSD & & \\
\hline B-Control & 0.1200 & 1.0000 & 0.2782 & 0.0000 & 0.4636 & 91.287 & 5 & & & & 3 & 3 \\
\hline 0.1 & 0.2800 & 2.3333 & 0.4996 & 0.0000 & 0.8861 & 66.067 & 5 & -1.195 & 2.409 & 0.4462 & 4 & 7 \\
\hline 0.5 & 0.2000 & 1.6667 & 0.4151 & 0.0000 & 0.6847 & 60.471 & 5 & -0.739 & 2.409 & 0.4462 & 4 & 5 \\
\hline 1 & 0.1600 & 1.3333 & 0.3224 & 0.0000 & 0.6847 & 95.483 & 5 & -0.239 & 2.409 & 0.4462 & 3 & 4 \\
\hline 5 & 0.2800 & 2.3333 & 0.5521 & 0.4636 & 0.6847 & 21.933 & 5 & -1.479 & 2.409 & 0.4462 & 5 & 7 \\
\hline 10 & 0.0800 & 0.6667 & 0.1855 & 0.0000 & 0.4636 & 136.931 & 5 & 0.501 & 2.409 & 0.4462 & 2 & 2 \\
\hline 50 & 0.2000 & 1.6667 & 0.3142 & 0.0000 & 0.8861 & 138.793 & 5 & -0.194 & 2.409 & 0.4462 & 2 & 0 \\
\hline
\end{tabular}

\begin{tabular}{|c|c|c|c|c|c|c|c|c|c|c|}
\hline Auxiliary Tests & & & & & Statistic & & Critical & & Skew & Kurt \\
\hline Shapiro-Wilk's Test indicates n & distribu & n $(p>0$ & & & 0.9643 & & 0.91 & & 0.0355 & -0.8418 \\
\hline Bartlett's Test indicates equal v & $\operatorname{ces}(p=$ & .48) & & & 5.5195 & & 16.812 & & & \\
\hline Hypothesis Test (1-tail, 0.05) & NOEC & LOEC & ChV & TU & MSDu & MSB & MSE & F-Stat & F-Prob & df \\
\hline Dunnett's Test & 50 & $>50$ & & & 0.0475 & 0.0832 & 0.0858 & 0.9693 & 0.4638 & 6,28 \\
\hline
\end{tabular}


Date:

Date:

ple Date:

ments:

\begin{tabular}{|rccccc}
\hline onc-\% & 1 & 2 & 3 & 4 & 5 \\
\hline B-Control & 0.2000 & 0.2000 & 0.0000 & 0.0000 & 0.2000 \\
0.1 & 0.0000 & 0.0000 & 0.0000 & 0.0000 & 0.0000 \\
0.5 & 0.0000 & 0.4000 & 0.2000 & 0.0000 & 0.2000 \\
1 & 0.0000 & 0.0000 & 0.0000 & 0.4000 & 0.0000 \\
5 & 0.0000 & 0.0000 & 0.0000 & 0.0000 & 0.2000 \\
2.5 & 0.0000 & 0.0000 & 0.0000 & 0.0000 & 0.0000 \\
25 & 0.0000 & 0.0000 & 0.0000 & 0.0000 & 0.0000
\end{tabular}

Test 10:

Lab ID:

Protocol: MBP 90-Anderson et al.

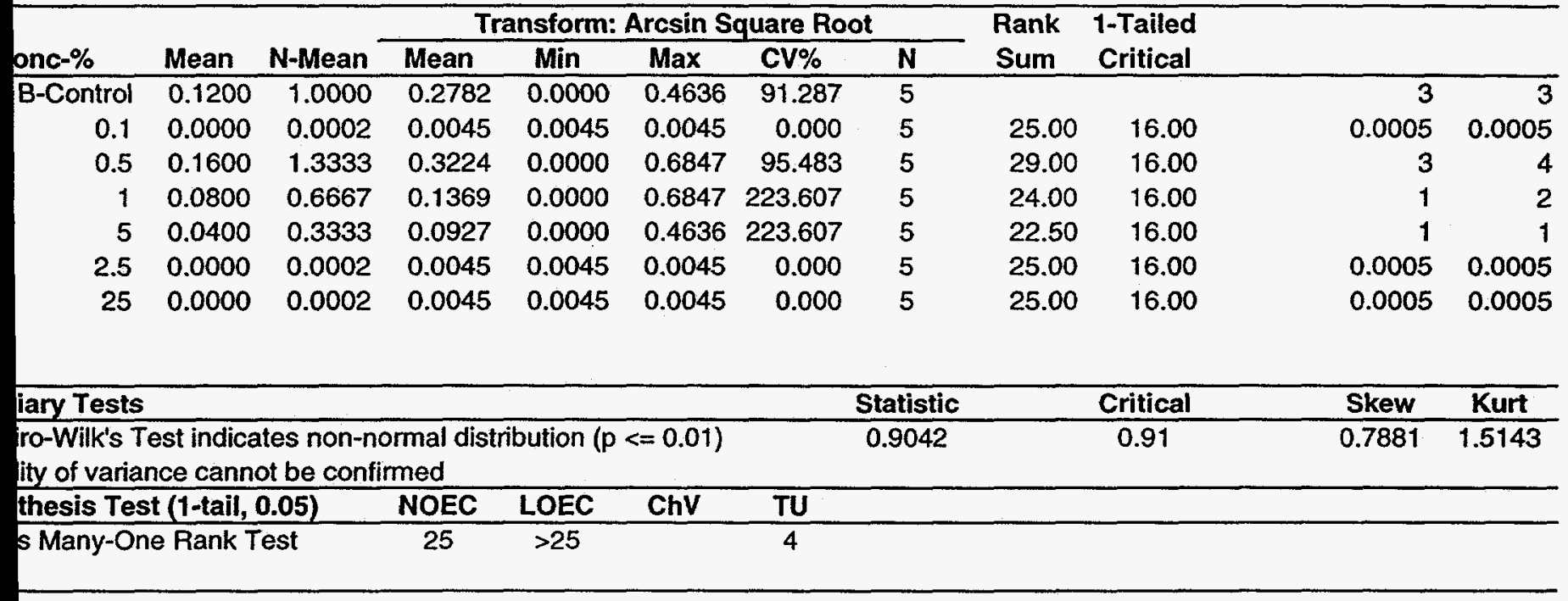

\section{minated}

Sample ID:

Sample Type:

Test Species:
QUFA 


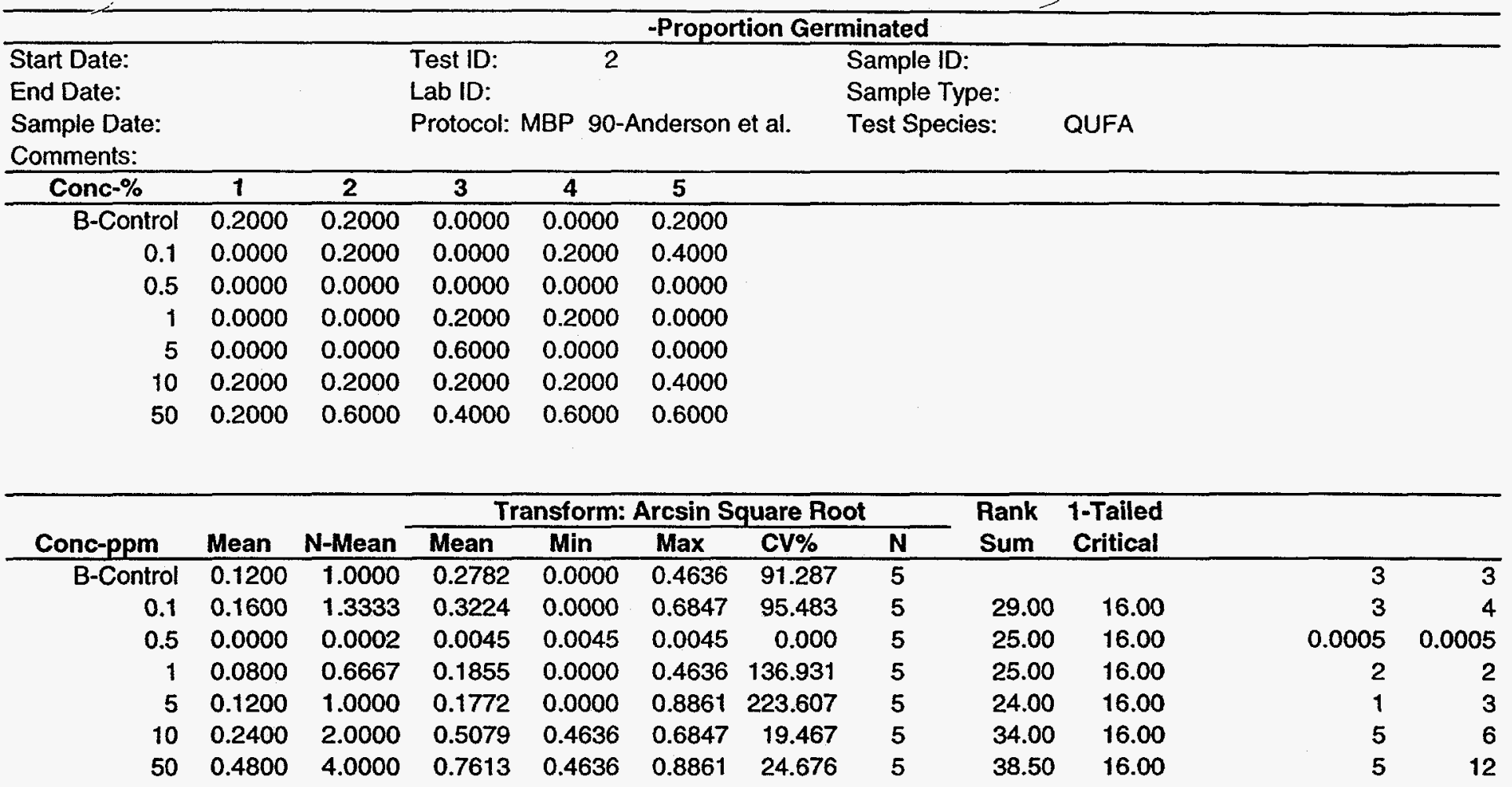

\begin{tabular}{|c|c|c|c|c|c|c|c|c|}
\hline Auxiliary Tests & & & & & Statistic & Critical & Skew & Kurt \\
\hline $\begin{array}{l}\text { Shapiro-Wilk's Test indicates n } \\
\text { Equality of variance cannot be }\end{array}$ & $\begin{array}{l}\text { I distribu } \\
\text { rmed }\end{array}$ & $n(p>0$ & & & 0.9354 & 0.91 & 0.8465 & 1.4242 \\
\hline Hypothesis Test (1-tail, 0.05) & NOEC & LOEC & ChV & TU & & & & \\
\hline Steel's Many-One Rank Test & 50 & $>50$ & & 2 & & & & \\
\hline
\end{tabular}




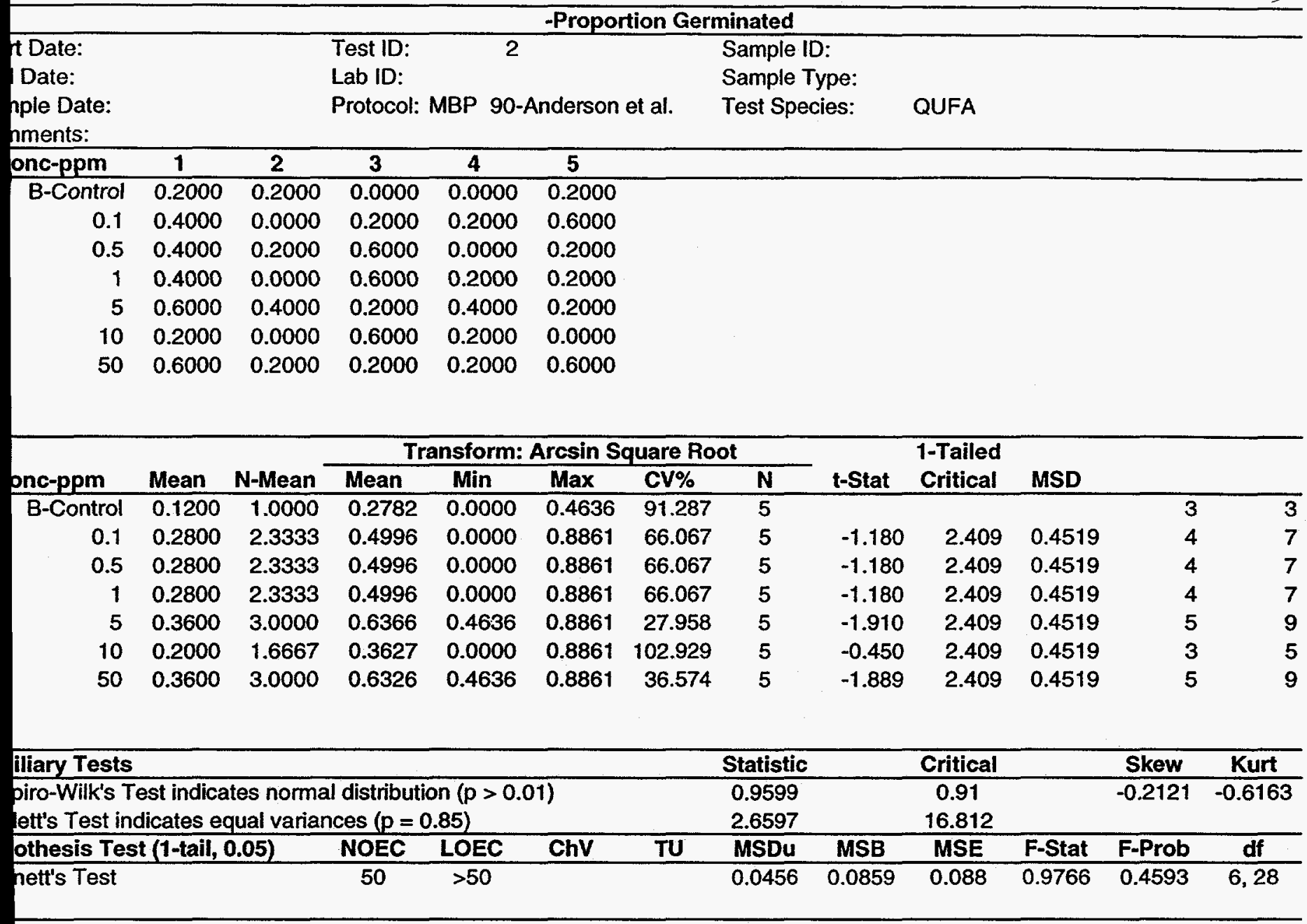




\begin{tabular}{|c|c|c|c|c|c|c|c|c|c|c|c|}
\hline \multicolumn{12}{|c|}{-Proportion Germinated } \\
\hline $\begin{array}{l}\text { Start Date: } \\
\text { End Date: } \\
\text { Sample Date: } \\
\text { Comments: }\end{array}$ & & & \multicolumn{4}{|c|}{ 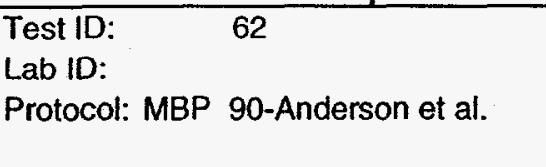 } & \multicolumn{2}{|c|}{$\begin{array}{l}\text { Sample ID: } \\
\text { Sample Type: } \\
\text { Test Species: }\end{array}$} & \multirow[t]{2}{*}{ RASA } & & \\
\hline Conc- $\%$ & 1 & 2 & 3 & 4 & 5 & & & & & & \\
\hline B-Control & 1.0000 & 1.0000 & 0.8000 & 0.8000 & 1.0000 & & & & & & \\
\hline 0.5 & 0.8000 & 1.0000 & 0.8000 & 1.0000 & 1.0000 & & & & & & \\
\hline 1 & 1.0000 & 0.6000 & 0.8000 & 1.0000 & 1.0000 & & & & & & \\
\hline 5 & 1.0000 & 0.8000 & 1.0000 & 1.0000 & 1.0000 & & & & & & \\
\hline 10 & 0.8000 & 1.0000 & 1.0000 & 0.4000 & 1.0000 & & & & & & \\
\hline 25 & 0.0000 & 0.8000 & 1.0000 & 0.8000 & 0.8000 & & & & & & \\
\hline \multirow[b]{3}{*}{ Conc-\% } & 0.6000 & 0.8000 & 0.8000 & 0.8000 & 0.8000 & & & & & & \\
\hline & & & \multicolumn{5}{|c|}{ Transform: Arcsin Square Root } & Rank & 1-Tailed & Number & Total \\
\hline & Mean & N-Mean & Mean & Min & Max & CV\% & $\mathbf{N}$ & Sum & Critical & Resp & Number \\
\hline B-Control & 0.9200 & 1.0000 & 1.2500 & 1.1071 & 1.3453 & 10.434 & 5 & & & $\overline{2}$ & 23 \\
\hline 0.5 & 0.9200 & 1.0000 & 1.2500 & 1.1071 & 1.3453 & 10.434 & 5 & 27.50 & 16.00 & 2 & 23 \\
\hline 1 & 0.8800 & 0.9565 & 1.2058 & 0.8861 & 1.3453 & 17.113 & 5 & 26.50 & 16.00 & 2 & 22 \\
\hline 5 & 0.9600 & 1.0435 & 1.2977 & 1.1071 & 1.3453 & 8.207 & 5 & 30.00 & 16.00 & 1 & 24 \\
\hline 10 & 0.8400 & 0.9130 & 1.1655 & 0.6847 & 1.3453 & 24.700 & 5 & 26.50 & 16.00 & 2 & 21 \\
\hline 25 & 0.6800 & 0.7391 & 0.9333 & 0.0000 & 1.3453 & 56.983 & 5 & 21.50 & 16.00 & 3 & 17 \\
\hline 50 & 0.7600 & 0.8261 & 1.0629 & 0.8861 & 1.1071 & 9.301 & 5 & 19.00 & 16.00 & 5 & 19 \\
\hline
\end{tabular}

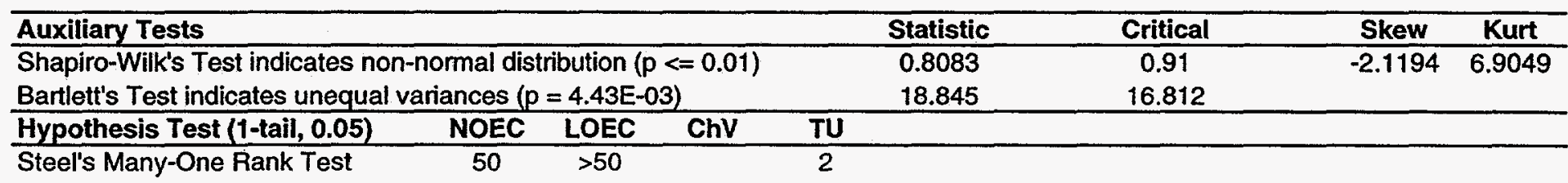

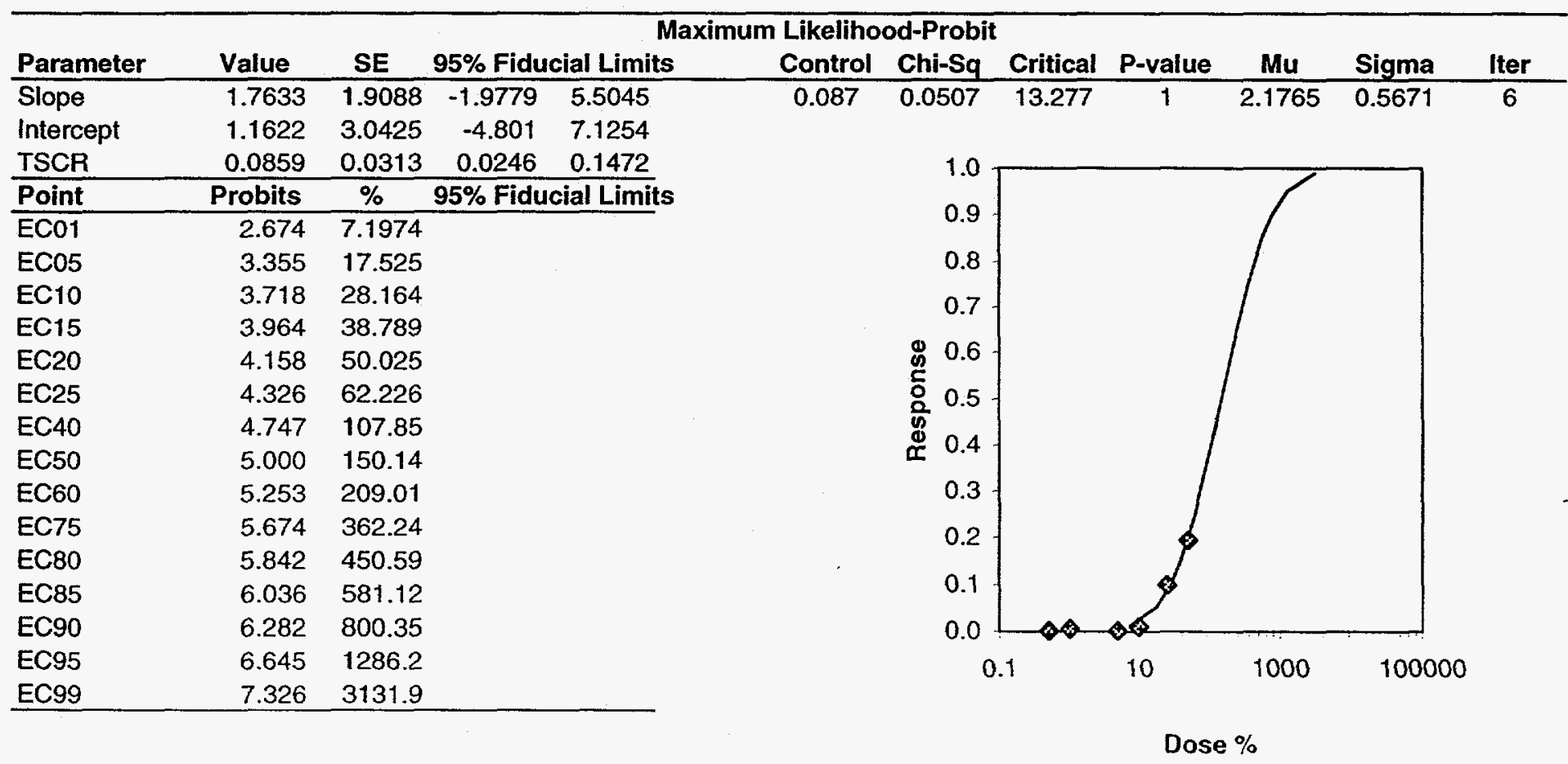


Date:

Date:

ple Date:

ments:

Fonc-\% B-Control

0.5
1

51.0000

$10 \quad 1.0000$

250.8000

$50 \quad 0.8000$
Test ID:

Lab ID:

Protocol: MBP 90-Anderson et al.
-Proportion Germinated

Sample 10:

Sample Type:

Test Species:
RASA

\begin{tabular}{|c|c|c|c|c|c|c|c|c|c|c|c|}
\hline \multirow[b]{2}{*}{ onc-\% } & \multirow[b]{2}{*}{ Mean } & \multirow[b]{2}{*}{ N-Mean } & \multicolumn{5}{|c|}{ Transform: Arcsin Square Root } & \multirow{2}{*}{$\begin{array}{l}\text { Rank } \\
\text { Sum }\end{array}$} & \multirow{2}{*}{$\begin{array}{l}\text { 1-Tailed } \\
\text { Critical }\end{array}$} & \multirow{2}{*}{$\begin{array}{c}\text { Number } \\
\text { Resp }\end{array}$} & \multirow{2}{*}{$\begin{array}{c}\text { Total } \\
\text { Number }\end{array}$} \\
\hline & & & Mean & Min & Max & CV\% & $\mathbf{N}$ & & & & \\
\hline B-Control & 0.9200 & 1.0000 & 1.2500 & 1.1071 & 1.3453 & 10.434 & 5 & & & 2 & 23 \\
\hline 0.5 & 0.8800 & 0.9565 & 1.2024 & 1.1071 & 1.3453 & 10.848 & 5 & 25.00 & 16.00 & 3 & 22 \\
\hline 1 & 0.9200 & 1.0000 & 1.2500 & 1.1071 & 1.3453 & 10.434 & 5 & 27.50 & 16.00 & 2 & 23 \\
\hline 5 & 0.9600 & 1.0435 & 1.2977 & 1.1071 & 1.3453 & 8.207 & 5 & 30.00 & 16.00 & 1 & 24 \\
\hline 10 & 0.9200 & 1.0000 & 1.2534 & 0.8861 & 1.3453 & 16.384 & 5 & 29.00 & 16.00 & 1. & 23 \\
\hline 25 & 0.8400 & 0.9130 & 1.1582 & 0.8861 & 1.3453 & 16.679 & 5 & 24.00 & 16.00 & 3 & 21 \\
\hline 50 & 0.9200 & 1.0000 & 1.2500 & 1.1071 & 1.3453 & 10.434 & 5 & 27.50 & 16.00 & 2 & 23 \\
\hline
\end{tabular}

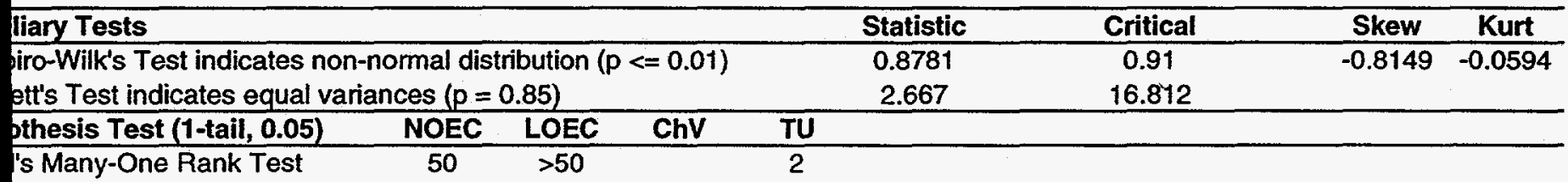

's Many-One Rank Test

\begin{tabular}{|c|c|c|c|c|c|c|c|c|c|c|c|}
\hline \multicolumn{12}{|c|}{ Maximum Likelihood-Probit } \\
\hline \multirow{2}{*}{ meter } & Value & SE & $95 \%$ Fidu & cial Limits & Control & Chi-S & Critical & P-value & Mu & Sigma & Iter \\
\hline & -0.2007 & 1.2063 & -2.565 & 2.1637 & 0.087 & 0.772 & 13.277 & 0.94 & -9.9064 & -4.9829 & 8 \\
\hline ept & 3.0119 & 1.6207 & -0.1646 & 6.1885 & & & & & & & \\
\hline & 0.0892 & 0.0592 & -0.0268 & 0.2051 & & & & 10 & & & \\
\hline & Probits & $\%$ & 95\% Fidu & cial Limits & & & & & & & \\
\hline & 2.674 & 48.491 & & & & & & 0.8 & & & \\
\hline & 3.355 & 0.0195 & & & & & & 0.8 & & & \\
\hline & 3.718 & 0.0003 & & & & & & & & & \\
\hline & 3.964 & \#\#\#\#\#\#\# & & & & & & & & & \\
\hline & 4.158 & \#\#\#\#\#\#\# & & & & क् & & & & & \\
\hline & 4.326 & \#\#\#\#\#\#\# & & & & 용 & & 0.5 & & & \\
\hline & 4.747 & \#\#\#\#\#\#\# & & & & $\overline{\mathscr{E}}$ & & 04 & & & \\
\hline & 5.000 & \#\#\#\#\#\#\# & & & & & & & & & \\
\hline & 5.253 & \#\#\#\#\#\#\# & & & & & & 0.3 & & & \\
\hline & 5.674 & \#\#\#\#\#\#\# & & & & & & 0.2 & & & \\
\hline & 5.842 & \#\#\#\#\#\#\# & & & & & & 01 & & & \\
\hline & 6.036 & \#\#\#\#\#\#\# & & & & & & 0.7 & & & \\
\hline & 6.282 & \#\#\#\#\#\#\# & & & & & & -0.0 & & & \\
\hline & 6.645 & \#\#\#\#\#\#\# & & & & & $1 E-1$ & $1 E-1$ & & 01 & \\
\hline & 7.326 & \#\#\#\#\#\#\# & & & & & & & & & \\
\hline
\end{tabular}

Dose \% 


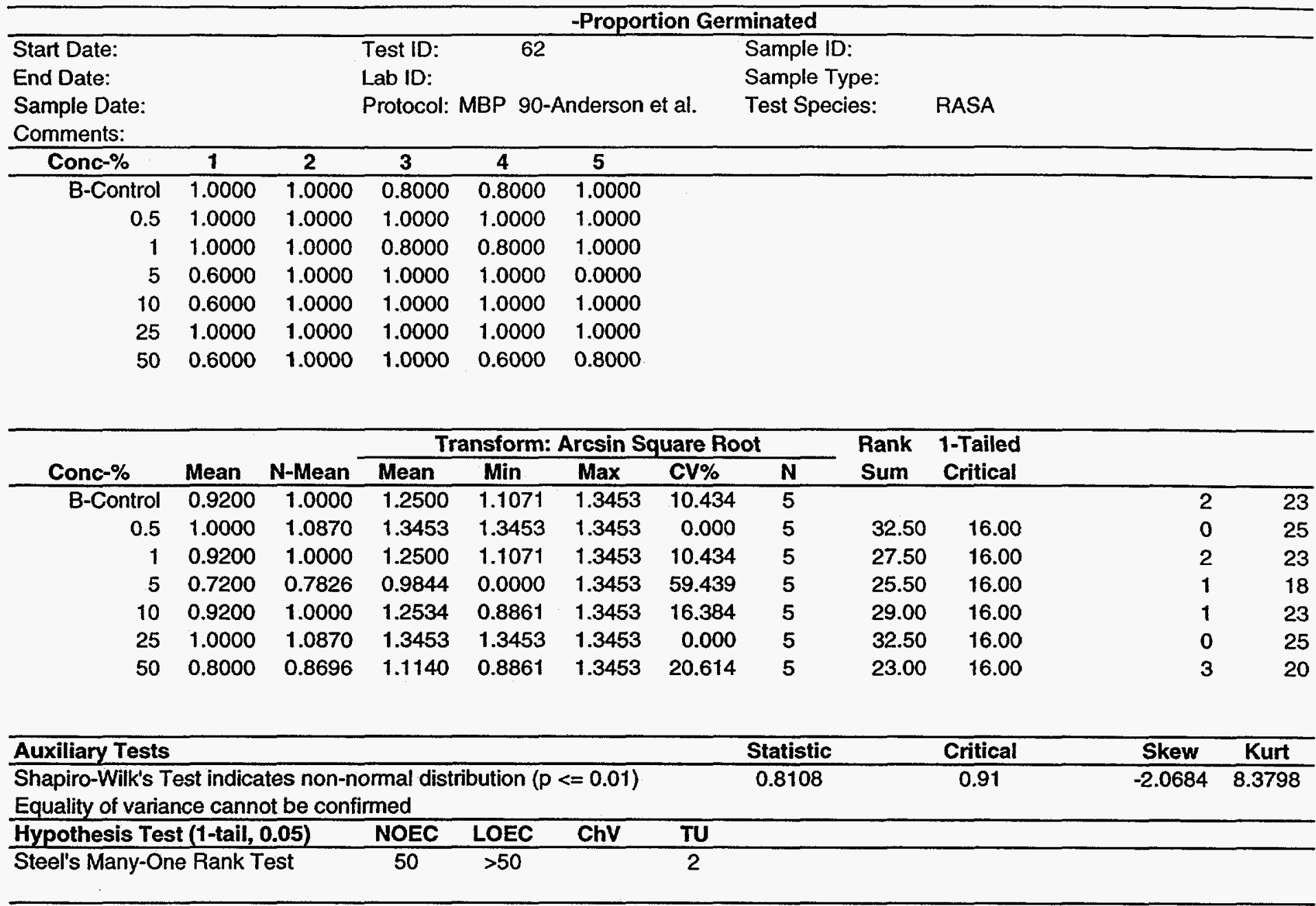


it Date:

Date:

nple Date:

nments:
Test ID:

Lab ID:

Protocol: MBP 90-Anderson et al.

\section{-Propotion Germinated}

Sample ID:

Sample Type:

Test Species:
RASA

\begin{tabular}{|c|c|c|c|c|c|}
\hline nc-ppm & 1 & 2 & 3 & 4 & 5 \\
\hline B-Control & 1.0000 & 1.0000 & 0.8000 & 0.8000 & 1.0000 \\
\hline 0.1 & 1.0000 & 1.0000 & 0.6000 & 0.8000 & 1.0000 \\
\hline 0.2 & 0.8000 & 0.8000 & 1.0000 & 1.0000 & 1.0000 \\
\hline 0.5 & 0.6000 & 1.0000 & 1.0000 & 1.0000 & 0.8000 \\
\hline 1 & 1.0000 & 0.8000 & 0.4000 & 0.8000 & 0.8000 \\
\hline 2.5 & 1.0000 & 0.6000 & 0.6000 & 1.0000 & 1.0000 \\
\hline 5 & 0.4000 & 0.6000 & 0.8000 & 0.8000 & 0.6000 \\
\hline
\end{tabular}

\begin{tabular}{|c|c|c|c|c|c|c|c|c|c|c|c|}
\hline \multirow[b]{2}{*}{ onc-ppm } & \multirow[b]{2}{*}{ Mean } & \multirow[b]{2}{*}{ N-Mean } & \multicolumn{5}{|c|}{ Transform: Arcsin Square Root } & \multirow{2}{*}{$\begin{array}{l}\text { Rank } \\
\text { Sum }\end{array}$} & \multirow{2}{*}{$\begin{array}{c}\text { 1-Tailed } \\
\text { Critical }\end{array}$} & \multirow{2}{*}{$\begin{array}{c}\text { Number } \\
\text { Resp }\end{array}$} & \multirow{2}{*}{$\begin{array}{c}\text { Total } \\
\text { Number }\end{array}$} \\
\hline & & & Mean & Min & Max & CV\% & $\bar{N}$ & & & & \\
\hline B-Control & 0.9200 & 1.0000 & 1.2500 & 1.1071 & 1.3453 & 10.434 & 5 & & & 2 & 23 \\
\hline 0.1 & 0.8800 & 0.9565 & 1.2058 & 0.8861 & 1.3453 & 17.113 & 5 & 26.50 & 16.00 & 2 & 22 \\
\hline 0.2 & 0.9200 & 1.0000 & 1.2500 & 1.1071 & 1.3453 & 10.434 & 5 & 27.50 & 16.00 & 2 & 23 \\
\hline 0.5 & 0.8800 & 0.9565 & 1.2058 & 0.8861 & 1.3453 & 17.113 & 5 & 26.50 & 16.00 & 2 & 22 \\
\hline 1 & 0.7600 & 0.8261 & 1.0703 & 0.6847 & 1.3453 & 22.324 & 5 & 21.50 & 16.00 & 4 & 19 \\
\hline 2.5 & 0.8400 & 0.9130 & 1.1616 & 0.8861 & 1.3453 & 21.653 & 5 & 25.50 & 16.00 & 2 & 21 \\
\hline 5 & 0.6400 & 0.6957 & 0.9342 & 0.6847 & 1.1071 & 19.050 & 5 & 17.00 & 16.00 & 5 & 16 \\
\hline
\end{tabular}

\begin{tabular}{|c|c|c|c|c|c|c|c|c|c|c|c|c|}
\hline \multicolumn{7}{|c|}{ liary Tests } & Statistic & & Critical & & Skew & Kurt \\
\hline \multirow{2}{*}{\multicolumn{7}{|c|}{$\begin{array}{l}\text { biro-Wilk's Test indicates non-normal distribution ( } p<=0.01 \text { ) } \\
\text { ett's Test indicates equal variances }(p=0.83 \text { ) }\end{array}$}} & 0.898 & & 0.91 & & -0.6707 & -0.7345 \\
\hline & & & & & & & 2.8518 & & 16.812 & & & \\
\hline \multicolumn{3}{|c|}{ othesis Test (1-tail, 0.05 ) } & NOEC & LOEC & ChV & TU & & & & & & \\
\hline \multicolumn{3}{|c|}{ I's Many-One Rank Test } & 5 & $>5$ & & & & & & & & \\
\hline \multicolumn{13}{|c|}{ Maximum Likelihood-Probit } \\
\hline \multirow{4}{*}{$\begin{array}{l}\text { meter } \\
\text { cept } \\
\mathrm{R} \\
\end{array}$} & Value & SE & 95\% Fidu & cial Limits & & Control & Chi-Sq & Critical & P-value & Mu & Sigma & Iter \\
\hline & 1.198 & 1.3793 & -1.5054 & 3.9014 & & 0.087 & 2.5928 & 13.277 & 0.63 & 1.447 & 0.8347 & 5 \\
\hline & 3.2664 & 0.7612 & 1.7745 & 4.7584 & & & & & & & & \\
\hline & 0.0902 & 0.0406 & 0.0107 & 0.1698 & & & 1.0 & & & & & \\
\hline \multirow[t]{16}{*}{ 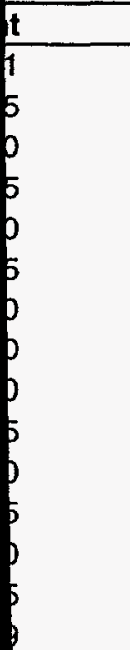 } & Probits & ppm & $95 \%$ Fidu & cial Limits & & & & & & & & \\
\hline & 2.674 & 0.32 & & & & & 0.9 & & & & & \\
\hline & 3.355 & 1.1859 & & & & & 0.8 & & & & & \\
\hline & 3.718 & 2.384 & & & & & 0.7 & & & & & \\
\hline & 3.964 & 3.8187 & & & & & & & & & & \\
\hline & 4.158 & 5.553 & & & & & 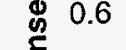 & & & & & \\
\hline & 4.326 & 7.6566 & & & & & 0.5 & & & & & \\
\hline & 4.747 & 17.202 & & & & & & & & & & \\
\hline & 5.000 & 27.993 & & & & & & & & & & \\
\hline & 5.253 & 45.553 & & & & & 0.3 & & & & & \\
\hline & 5.674 & 102.34 & & & & & 0.2 & & & & & \\
\hline & 5.842 & 141.11 & & & & & & & & & & \\
\hline & 6.036 & 205.2 & & & & & 0.1 & & & & & \\
\hline & 6.282 & 328.68 & & & & & 0.0 & & & & & \\
\hline & 6.645 & 660.73 & & & & & & & 10 & 1000 & 1000 & \\
\hline & 7.326 & 2448.4 & & & & & & & & & & \\
\hline
\end{tabular}

Dose ppm 


\section{Start Date:}

End Date:

Sample Date:

Comments:

\begin{tabular}{rccccc}
\hline Conc-ppm & $\mathbf{1}$ & $\mathbf{2}$ & $\mathbf{3}$ & $\mathbf{4}$ & $\mathbf{5}$ \\
\hline $\mathbf{1}$ & $\mathbf{1 . 0 0 0 0}$ & $\mathbf{1 . 0 0 0 0}$ & 0.8000 & 0.8000 & $\mathbf{1 . 0 0 0 0}$ \\
0.5 & 1.0000 & 1.0000 & 0.8000 & 0.4000 & 0.8000 \\
1 & 0.8000 & 0.8000 & 1.0000 & 1.0000 & 0.0000 \\
5 & 1.0000 & 1.0000 & 1.0000 & 1.0000 & 0.8000 \\
10 & 0.8000 & 1.0000 & 0.8000 & 1.0000 & 0.8000 \\
25 & 1.0000 & 0.8000 & 1.0000 & 1.0000 & 0.6000 \\
50 & 1.0000 & 0.8000 & 0.8000 & 0.8000 & 0.6000
\end{tabular}

\begin{tabular}{|c|c|c|c|c|c|c|c|c|c|c|c|}
\hline \multirow[b]{2}{*}{ Conc-ppm } & \multirow[b]{2}{*}{ Mean } & \multirow[b]{2}{*}{ N-Mean } & \multicolumn{5}{|c|}{ Transform: Arcsin Square Root } & \multirow{2}{*}{$\begin{array}{l}\text { Rank } \\
\text { Sum }\end{array}$} & \multirow{2}{*}{$\begin{array}{l}\text { 1-Tailed } \\
\text { Critical }\end{array}$} & \multirow{2}{*}{$\begin{array}{c}\text { Number } \\
\text { Resp }\end{array}$} & \multirow{2}{*}{$\begin{array}{c}\text { Total } \\
\text { Number }\end{array}$} \\
\hline & & & Mean & $\operatorname{Min}$ & Max & CV\% & $\mathbf{N}$ & & & & \\
\hline B-Control & 0.9200 & 1.0000 & 1.2500 & 1.1071 & 1.3453 & 10.434 & 5 & & & 2 & 23 \\
\hline 0.5 & 0.8000 & 0.8696 & 1.1179 & 0.6847 & 1.3453 & 24.139 & 5 & 24.00 & 16.00 & 3 & 20 \\
\hline 1 & 0.7200 & 0.7826 & 0.9810 & 0.0000 & 1.3453 & 57.204 & 5 & 24.00 & 16.00 & 2 & 18 \\
\hline 5 & 0.9600 & 1.0435 & 1.2977 & 1.1071 & 1.3453 & 8.207 & 5 & 30.00 & 16.00 & 1 & 24 \\
\hline 10 & 0.8800 & 0.9565 & 1.2024 & 1.1071 & 1.3453 & 10.848 & 5 & 25.00 & 16.00 & 3 & 22 \\
\hline 25 & 0.8800 & 0.9565 & 1.2058 & 0.8861 & 1.3453 & 17.113 & 5 & 26.50 & 16.00 & 2 & 22 \\
\hline 50 & 0.8000 & 0.8696 & 1.1106 & 0.8861 & 1.3453 & 14.625 & 5 & 21.50 & 16.00 & 4 & 20 \\
\hline
\end{tabular}

\begin{tabular}{|c|c|c|c|c|}
\hline Auxiliary Tests & Statistic & Critical & Skew & Kurt \\
\hline Shapiro-Wilk's Test indicates non-normal distribution $(p<=0.01)$ & 0.8475 & 0.91 & -2.0241 & 7.0077 \\
\hline Bartlett's Test indicates unequal variances $(p=8.10 \mathrm{E}-03)$ & 17.344 & 16.812 & & \\
\hline
\end{tabular}

\begin{tabular}{lcccc}
\hline Hypothesis Test (1-tail, 0.05$)$ & NOEC & LOEC & ChV & TU \\
\hline Steel's Many-One Rank Test & 50 & $>50$ & &
\end{tabular}

Sample ID:

Lab ID: $\quad$ Sample Type:

RASA

\begin{tabular}{|c|c|c|c|c|c|c|c|c|c|c|}
\hline \multirow{3}{*}{$\frac{\text { Parameter }}{\text { Slope }}$} & \multirow{3}{*}{$\frac{\text { Value }}{-514107}$} & \multicolumn{7}{|c|}{ Maximum Likelihood-Probit } & \multirow[b]{2}{*}{ Sigma } & \multirow[b]{2}{*}{ Iter } \\
\hline & & SE & 95\% Fiducial Limits & Control & Chi-Sq & Critical & P-value & Mu & & \\
\hline & & $6 E+06$ & $-1 E+07$ & 0.087 & 0.0053 & 13.277 & 1 & 1.699 & \#\#\#\#\#\#\# & 25 \\
\hline Intercept & 873456 & $1 E+07$ & $-2 E+07$ & & & & & & & \\
\hline TSCR & 0.1169 & 0.0355 & $0.0473 \quad 0.1865$ & & 1.0 & & & & & \\
\hline Point & Probits & ppm & 95\% Fiducial Limits & & & & & & & \\
\hline EC01 & 2.674 & 50 & & & 0.9 & & & & & \\
\hline ECO5 & 3.355 & 50 & & & 0.8 & & & & & \\
\hline EC10 & 3.718 & 50 & & & & & & & & \\
\hline EC15 & 3.964 & 50 & & & 0.7 & & & & & \\
\hline $\mathrm{EC} 20$ & 4.158 & 50 & & & $\$ 0.6$ & & & & & \\
\hline $\mathrm{EC} 25$ & 4.326 & 50 & & & $\stackrel{\text { S }}{5}$ & & & & & \\
\hline EC40 & 4.747 & 50 & & & 务 0.5 & & & & & \\
\hline EC50 & 5.000 & 50 & & & $\stackrel{\Phi}{\simeq} 0.4$ & & & & & \\
\hline EC60 & 5.253 & 50 & & & $0_{3}$ & & & & & \\
\hline EC75 & 5.674 & 50 & & & 0.3 & & & & & \\
\hline EC80 & 5.842 & 50 & & & 0.2 & & & & & \\
\hline EC85 & 6.036 & 49.999 & & & & & & & 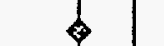 & \\
\hline EC90 & 6.282 & 49.999 & & & 0.1 & $\theta$ & & $\theta$ & & \\
\hline EC95 & 6.645 & 49.999 & & & 0.0 & & 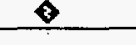 & & 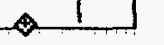 & \\
\hline EC99 & 7.326 & 49.999 & & & & .1 & 1 & 10 & 100 & \\
\hline
\end{tabular}




\begin{tabular}{|c|c|c|c|c|c|c|c|c|c|c|c|}
\hline \multicolumn{12}{|c|}{-Proportion Germinated } \\
\hline \multirow[t]{2}{*}{$\begin{array}{l}\text { Date: } \\
\text { Date: } \\
\text { nple Date: } \\
\text { nments: } \\
\text { Conc-\% }\end{array}$} & \multirow[b]{2}{*}{1} & \multirow[b]{2}{*}{2} & \multirow[t]{2}{*}{$\begin{array}{l}\text { Test ID: } \\
\text { Lab ID: } \\
\text { Protocol: } \\
\mathbf{3}\end{array}$} & \multirow[t]{2}{*}{$\begin{array}{r}62 \\
\text { MBP } 90- \\
4\end{array}$} & \multicolumn{2}{|c|}{ Anderson et al. } & \multicolumn{2}{|c|}{$\begin{array}{l}\text { Sample ID: } \\
\text { Sample Type: } \\
\text { Test Species: }\end{array}$} & \multirow[t]{2}{*}{ RASA } & & \\
\hline & & & & & 5 & & & & & & \\
\hline B-Control & 1.0000 & 1.0000 & 0.8000 & 0.8000 & 1.0000 & & & & & & \\
\hline 0.5 & 1.0000 & 1.0000 & 1.0000 & 1.0000 & 1.0000 & & & & & & \\
\hline 1 & 0.6000 & 1.0000 & 0.8000 & 1.0000 & 0.6000 & & & & & & \\
\hline 5 & 0.8000 & 0.8000 & 0.4000 & 1.0000 & 0.8000 & & & & & & \\
\hline 10 & 0.8000 & 1.0000 & 0.8000 & 1.0000 & 0.8000 & & & & & & \\
\hline \multirow{3}{*}{$\begin{array}{l}25 \\
50\end{array}$} & 0.8000 & 1.0000 & 1.0000 & 1.0000 & 1.0000 & & & & & & \\
\hline & 1.0000 & 0.8000 & 1.0000 & 1.0000 & 1.0000 & & & & & & \\
\hline & & & \multicolumn{5}{|c|}{ Transform: Arcsin Square Root } & Rank & 1-Tailed & Number & Total \\
\hline Conc-\% & Mean & N-Mean & Mean & Min & Max & CV\% & $\mathbf{N}$ & Sum & Critical & Resp & Number \\
\hline B-Control & 0.9200 & 1.0000 & 1.2500 & 1.1071 & 1.3453 & 10.434 & 5 & & & 2 & 23 \\
\hline 0.5 & 1.0000 & 1.0870 & 1.3453 & 1.3453 & 1.3453 & 0.000 & 5 & 32.50 & 16.00 & 0 & 25 \\
\hline 1 & 0.8000 & 0.8696 & 1.1140 & 0.8861 & 1.3453 & 20.614 & 5 & 23.00 & 16.00 & 3 & 20 \\
\hline 5 & 0.7600 & 0.8261 & 1.0703 & 0.6847 & 1.3453 & 22.324 & 5 & 21.50 & 16.00 & 4 & 19 \\
\hline 10 & 0.8800 & 0.9565 & 1.2024 & 1.1071 & 1.3453 & 10.848 & 5 & 25.00 & 16.00 & 3 & 22 \\
\hline 25 & 0.9600 & 1.0435 & 1.2977 & 1.1071 & 1.3453 & 8.207 & 5 & 30.00 & 16.00 & 1 & 24 \\
\hline 50 & 0.9600 & 1.0435 & 1.2977 & 1.1071 & 1.3453 & 8.207 & 5 & 30.00 & 16.00 & 1 & 24 \\
\hline
\end{tabular}

\begin{tabular}{|c|c|c|c|c|c|c|c|c|c|c|c|c|}
\hline \multirow{2}{*}{\multicolumn{7}{|c|}{$\begin{array}{l}\text { fliary Tests } \\
\text { piro-Wilk's Test indicates normal distribution }(p>0.01)\end{array}$}} & \multirow{2}{*}{$\frac{\text { Statistic }}{0.9454}$} & \multicolumn{3}{|c|}{$\frac{\text { Critical }}{0.91}$} & \multirow{2}{*}{$\begin{array}{c}\text { Skew } \\
-0.549\end{array}$} & \multirow{2}{*}{$\frac{\text { Kurt }}{0.7188}$} \\
\hline & & & & & & & & & 0.91 & & & \\
\hline \multicolumn{3}{|c|}{ othesis Test (1-tail, 0.05) } & NOEC & LOEC & ChV & TU & & & & & & \\
\hline \multicolumn{3}{|c|}{ I's Many-One Rank Test } & 50 & $>50$ & & 2 & & & & & & \\
\hline \multicolumn{13}{|c|}{ Maximum Likelihood-Probit } \\
\hline meter & Value & SE & \multicolumn{3}{|c|}{ 95\% Fiducial Limits } & Control & Chi-Sq & Critical & P-value & Mu & Sigma & Iter \\
\hline$e$ & -0.1078 & 0.515 & -1.1172 & 0.9016 & & 0.087 & 2.4186 & 13.277 & 0.66 & -15.593 & -9.2791 & 5 \\
\hline cept & 3.3195 & 0.8565 & 1.6408 & 4.9982 & & & & & & & & \\
\hline $\mathbf{R}$ & 0.0854 & 0.0583 & -0.0289 & 0.1997 & & & & & & 7.0 & & \\
\hline t & Probits & $\%$ & $95 \%$ Fidu & cial Limits & & & & & & 0.9 & & \\
\hline 1 & 2.674 & 984286 & & & & & & & & 0.0 & & \\
\hline 5 & 3.355 & 0.4671 & & & & & & & & 0.8 & & \\
\hline 0 & 3.718 & 0.0002 & & & & & & & & 0.7 & & \\
\hline 5 & 3.964 & \#\#\#\#\#\#\# & & & & & gू & & & 0.6 & & \\
\hline 0 & 4.158 & \#\#\#\#\#\#\# & & & & & $\overline{8}$ & & & .5 & & \\
\hline 5 & 4.326 & \#\#\#\#\#\#\# & & & & & $\bar{g}$ & & & & & \\
\hline p & 4.747 & \#\#\#\#\#\#\# & & & & & & & & & & \\
\hline $\mathrm{b}$ & 5.000 & \#\#\#\#\#\#\# & & & & & & & & & & \\
\hline 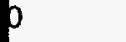 & 5.253 & \#\#\#\#\#\#\# & & & & & & & & 0.2 & & \\
\hline 5 & 5.674 & \#\#\#\#\#\#\# & & & & & & & & 0.1 & & \\
\hline b & 5.842 & \#\#\#\#\#\#\# & & & & & & & & $\theta .0$ & $\infty$ & \\
\hline$P$ & 6.036 & \#\#\#\#\#\#\# & & & & & $1 E-38$ & $1 E-27$ & $1 E-1$ & 0.000 & 01100 & \\
\hline D & 6.282 & \#\#\#\#\#\#\# & & & & & & & & & & \\
\hline & 6.645 & \#\#\#\#\#\#\# & & & & & & & & & & \\
\hline & 7.326 & \#\#\#\#\#\#\# & & & & & & & & & & \\
\hline
\end{tabular}

Dose \% 


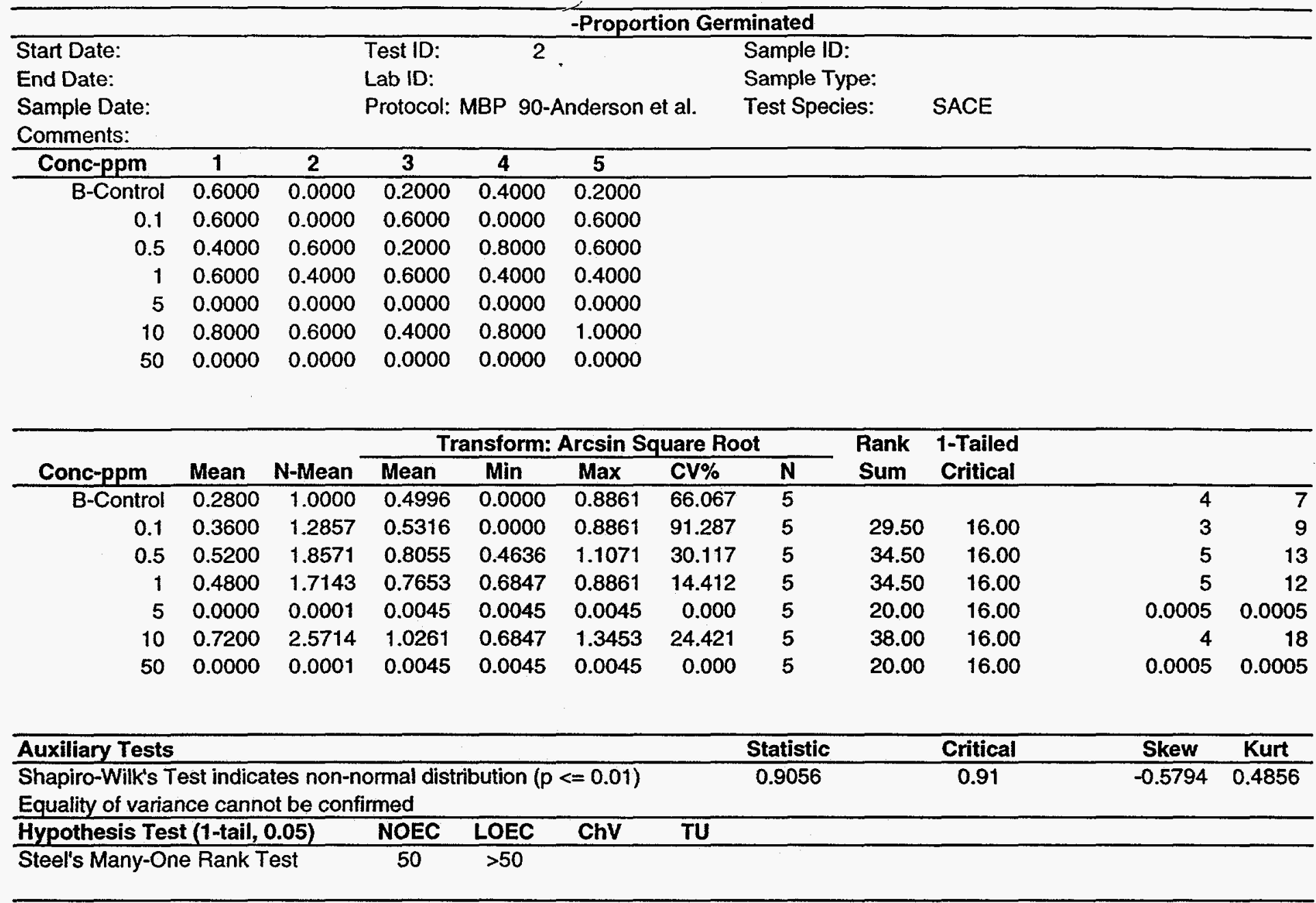




\begin{tabular}{|c|c|c|c|c|c|c|c|c|c|c|c|}
\hline \multicolumn{12}{|c|}{-Proportion Germinated } \\
\hline \multirow[t]{2}{*}{$\begin{array}{l}\text { Date: } \\
\text { Date: } \\
\text { ple Date: } \\
\text { ments: } \\
\text { nc-ppm }\end{array}$} & \multirow[b]{2}{*}{1} & \multirow{2}{*}{\multicolumn{2}{|c|}{$\begin{array}{l}\text { Test ID: } \\
\text { Lab ID: } \\
\text { Protocol: } \\
\mathbf{3}\end{array}$}} & \multirow[t]{2}{*}{$\begin{array}{r}2 \\
\text { MBP } 90-/ \\
4\end{array}$} & \multicolumn{2}{|c|}{ Anderson et al. } & \multicolumn{2}{|c|}{$\begin{array}{l}\text { Sample ID: } \\
\text { Sample Type: } \\
\text { Test Species: }\end{array}$} & \multirow[t]{2}{*}{ SACE } & & \\
\hline & & & & & 5 & & & & & & \\
\hline B-Control & 0.6000 & 0.0000 & 0.2000 & 0.4000 & 0.2000 & & & & & & \\
\hline 0.1 & 0.2000 & 0.2000 & 0.6000 & 0.2000 & 0.2000 & & & & & & \\
\hline 0.5 & 0.0000 & 0.4000 & 0.4000 & 0.6000 & 0.2000 & & & & & & \\
\hline 1 & 0.6000 & 0.6000 & 0.6000 & 0.6000 & 0.6000 & & & & & & \\
\hline 5 & 0.4000 & 1.0000 & 0.2000 & 0.4000 & 0.6000 & & & & & & \\
\hline 10 & 0.4000 & 0.0000 & 0.8000 & 0.0000 & 0.2000 & & & & & & \\
\hline \multirow[t]{3}{*}{50} & 0.2000 & 0.0000 & 0.0000 & 0.2000 & 0.2000 & & & & & & \\
\hline & & & \multicolumn{5}{|c|}{ Transform: Arcsin Square Root } & \multirow{2}{*}{$\begin{array}{l}\text { Rank } \\
\text { Sum }\end{array}$} & \multirow{2}{*}{$\begin{array}{l}\text { 1-Tailed } \\
\text { Critical } \\
\end{array}$} & & \\
\hline & Mean & N-Mean & Mean & Min & Max & CV\% & $\mathbf{N}$ & & & & \\
\hline B-Control & 0.2800 & 1.0000 & 0.4996 & 0.0000 & 0.8861 & 66.067 & 5 & & & 4 & $\overline{7}$ \\
\hline 0.1 & 0.2800 & 1.0000 & 0.5481 & 0.4636 & 0.8861 & 34.465 & 5 & 27.50 & 16.00 & 5 & 7 \\
\hline 0.5 & 0.3200 & 1.1429 & 0.5438 & 0.0000 & 0.8861 & 62.290 & 5 & 29.00 & 16.00 & 4 & 8 \\
\hline 1 & 0.6000 & 2.1429 & 0.8861 & 0.8861 & 0.8861 & 0.000 & 5 & 37.50 & 16.00 & 5 & 15 \\
\hline 5 & 0.5200 & 1.8571 & 0.8129 & 0.4636 & 1.3453 & 40.968 & 5 & 33.50 & 16.00 & 4 & 13 \\
\hline 10 & 0.2800 & 1.0000 & 0.4511 & 0.0000 & 1.1071 & 104.690 & 5 & 26.50 & 16.00 & 3 & 7 \\
\hline 50 & 0.1200 & 0.4286 & 0.2782 & 0.0000 & 0.4636 & 91.287 & 5 & 22.00 & 16.00 & 3 & 3 \\
\hline \multicolumn{7}{|l|}{ lary Tests } & Statistic & & Critical & Skew & Kurt \\
\hline \multicolumn{7}{|c|}{$\begin{array}{l}\text { iro-Wilk's Test indicates normal distribution }(p>0.01) \\
\text { lity of variance cannot be confirmed }\end{array}$} & 0.9699 & & 0.91 & 0.0751 & 0.1343 \\
\hline \multirow{2}{*}{\multicolumn{3}{|c|}{$\begin{array}{l}\text { thesis Test (1-tail, } 0.05) \\
\text { s Many-One Rank Test }\end{array}$}} & NOEC & LOEC & ChV & TU & & & & & \\
\hline & & & 50 & $>50$ & & & & & & & \\
\hline
\end{tabular}




\begin{tabular}{lllll}
\hline & & -Proportion Germinated & \\
\hline Start Date: & Test ID: & 2 & Sample ID: \\
End Date: & Lab ID: & Sample Type: & SACE \\
Sample Date: & Protocol: MBP & 90-Anderson et al. & Test Species: & SA \\
Comments: & & & & \\
\hline
\end{tabular}

\begin{tabular}{rccccc}
\hline Conc-ppm & 1 & $\mathbf{2}$ & $\mathbf{3}$ & $\mathbf{4}$ & $\mathbf{5}$ \\
\hline B-Control & 0.6000 & 0.0000 & 0.2000 & 0.4000 & 0.2000 \\
0.1 & 0.6000 & 1.0000 & 0.6000 & 0.8000 & 0.2000 \\
0.5 & 0.8000 & 0.4000 & 0.4000 & 0.6000 & 0.8000 \\
1 & 0.4000 & 1.0000 & 0.6000 & 0.4000 & 0.6000 \\
5 & 0.4000 & 0.8000 & 0.0000 & 0.2000 & 0.4000 \\
10 & 0.8000 & 1.0000 & 0.4000 & 1.0000 & 0.4000 \\
50 & 0.4000 & 0.0000 & 0.6000 & 0.0000 & 0.0000
\end{tabular}

\begin{tabular}{|c|c|c|c|c|c|c|c|c|c|c|c|c|}
\hline \multirow[b]{2}{*}{ Conc-ppm } & \multirow[b]{2}{*}{ Mean } & \multirow[b]{2}{*}{ N-Mean } & \multicolumn{5}{|c|}{ Transform: Arcsin Square Root } & \multicolumn{3}{|c|}{ 1-Tailed } & & \\
\hline & & & Mean & Min & $\operatorname{Max}$ & CV\% & $\mathbf{N}$ & t-Stat & Critical & MSD & & \\
\hline B-Control & 0.2800 & 1.0000 & 0.4996 & 0.0000 & 0.8861 & 66.067 & 5 & & & & 4 & $\overline{7}$ \\
\hline 0.1 & 0.6400 & 2.2857 & 0.9376 & 0.4636 & 1.3453 & 34.759 & 5 & -2.054 & 2.409 & 0.5137 & 4 & 16 \\
\hline 0.5 & 0.6000 & 2.1429 & 0.8940 & 0.6847 & 1.1071 & 23.632 & 5 & -1.849 & 2.409 & 0.5137 & 5 & 15 \\
\hline 1 & 0.6000 & 2.1429 & 0.8974 & 0.6847 & 1.3453 & 30.073 & 5 & -1.865 & 2.409 & 0.5137 & 4 & 15 \\
\hline 5 & 0.3600 & 1.2857 & 0.5880 & 0.0000 & 1.1071 & 68.521 & 5 & -0.415 & 2.409 & 0.5137 & 4 & 9 \\
\hline 10 & 0.7200 & 2.5714 & 1.0334 & 0.6847 & 1.3453 & 32.208 & 5 & -2.503 & 2.409 & 0.5137 & 3 & 18 \\
\hline 50 & 0.2000 & 0.7143 & 0.3142 & 0.0000 & 0.8861 & 138.793 & 5 & 0.870 & 2.409 & 0.5137 & 2 & 5 \\
\hline
\end{tabular}

\begin{tabular}{|c|c|c|c|c|c|c|c|c|c|c|}
\hline \multicolumn{5}{|l|}{ Auxiliary Tests } & \multicolumn{2}{|l|}{ Statistic } & \multicolumn{2}{|l|}{ Critical } & Skew & Kurt \\
\hline Shapiro-Wilk's Test indicates $n$ & distribu & on $(p>0$ & & & 0.9708 & & 0.91 & & 0.0374 & -0.8296 \\
\hline Bartlett's Test indicates equal v & $\operatorname{ces}(p=$ & $.88)$ & & & 2.3625 & & 16.812 & & & \\
\hline Hypothesis Test (1-tail, 0.05) & NOEC & LOEC & ChV & TU & MSDu & MSB & MSE & F-Stat & F-Prob & df \\
\hline Dunnett's Test & 50 & $>50$ & & & 0.2293 & 0.3632 & 0.1137 & 3.1942 & 0.0162 & 6,28 \\
\hline
\end{tabular}




\begin{tabular}{|c|c|c|c|c|c|c|c|}
\hline \multicolumn{8}{|c|}{-Proportion Germinated } \\
\hline \multicolumn{3}{|l|}{$\begin{array}{l}\text { Date: } \\
\text { Date: } \\
\text { ple Date: } \\
\text { ments: }\end{array}$} & $\begin{array}{l}\text { Test ID: } \\
\text { Lab ID: } \\
\text { Protocol: }\end{array}$ & \multicolumn{2}{|r|}{ 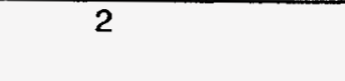 } & \multirow[t]{2}{*}{$\begin{array}{l}\text { Sample ID: } \\
\text { Sample Type: } \\
\text { Test Species: }\end{array}$} & \multirow[t]{2}{*}{ SACE } \\
\hline nc-ppm & 1 & 2 & 3 & 4 & 5 & & \\
\hline B-Control & 0.6000 & 0.0000 & 0.2000 & 0.4000 & 0.2000 & & \\
\hline 0.5 & 1.0000 & 0.8000 & 0.8000 & 0.8000 & 0.4000 & & \\
\hline 5 & 0.2000 & 0.0000 & 0.0000 & 0.0000 & 0.0000 & & \\
\hline 25 & 0.6000 & 0.6000 & 0.4000 & 0.0000 & 0.0000 & & \\
\hline
\end{tabular}

\begin{tabular}{|c|c|c|c|c|c|c|c|c|c|c|}
\hline \multirow[b]{2}{*}{ nc-ppm } & \multirow[b]{2}{*}{ Mean } & \multirow[b]{2}{*}{ N-Mean } & \multicolumn{5}{|c|}{ Transform: Arcsin Square Root } & \multicolumn{3}{|c|}{ 1-Tailed } \\
\hline & & & Mean & Min & Max & CV\% & $\mathbf{N}$ & t-Stat & Critical & MSD \\
\hline B-Control & 0.2800 & 1.0000 & 0.4996 & 0.0000 & 0.8861 & 66.067 & 5 & & & \\
\hline 0.5 & 0.7600 & 2.7143 & 1.0703 & 0.6847 & 1.3453 & 22.324 & 5 & -2.795 & 2.230 & 0.4554 \\
\hline 5 & 0.0400 & 0.1429 & 0.0927 & 0.0000 & 0.4636 & 223.607 & 5 & 1.993 & 2.230 & 0.4554 \\
\hline 25 & 0.3200 & 1.1429 & 0.4914 & 0.0000 & 0.8861 & 92.807 & 5 & 0.040 & 2.230 & 0.4554 \\
\hline
\end{tabular}

\begin{tabular}{|c|c|c|c|c|c|c|c|c|c|c|}
\hline iary Tests & & & & & Statistic & & Critical & & Skew & Kurt \\
\hline iro-Wilk's Test indicates ne & distribu & on $(p>0$ & & & 0.9105 & & 0.868 & & -0.3515 & -0.7332 \\
\hline tt's Test indicates equal $v$ & $\operatorname{ces}(p=$ & .44) & & & 2.7286 & & 11.345 & & & \\
\hline thesis Test (1-tail, 0.05) & NOEC & LOEC & ChV & TU & MSDu & MSB & MSE & F-Stat & F-Prob & $\overline{\mathrm{df}}$ \\
\hline ett's Test & 25 & $>25$ & & & 0.2276 & 0.8087 & 0.1043 & 7.7576 & $2.0 \mathrm{E}-03$ & 3,16 \\
\hline
\end{tabular}




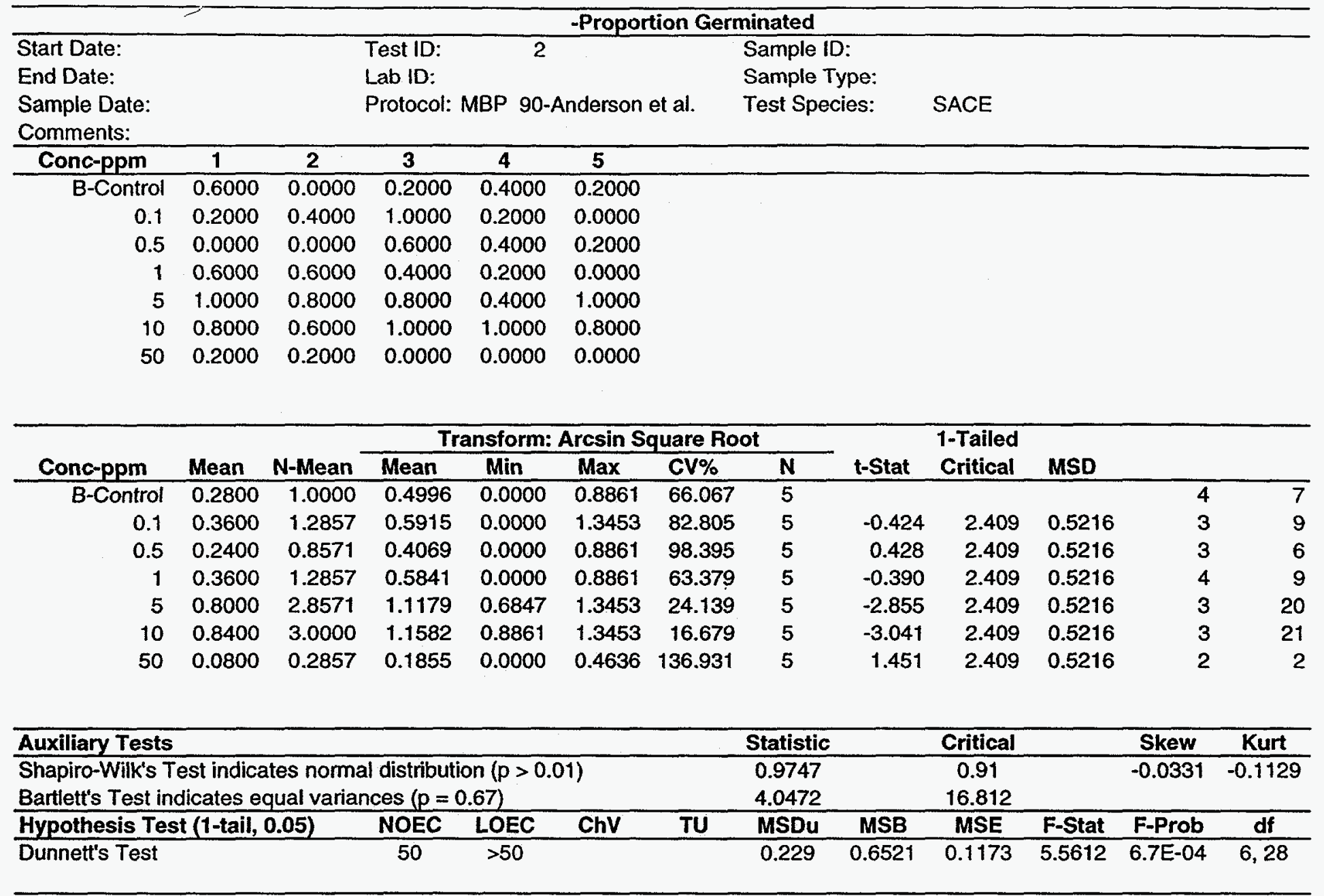


Species Chem NOEL(ppm) LOEL(ppm) EC Value(ppm)

\begin{tabular}{lcccc}
\hline LIST & PCE & 10 & 50 & UTA \\
LIST & NI & 50 & $>50$ & UTA \\
LIST & MEOH & 0.5 & 5 & UTA \\
LIST & Cd & 10 & 50 & UTA \\
LST & ATRA & 1 & 5 & UTA \\
LIST & ANTH & 1 & 5 & UTA \\
\hline LASA & PCE & UTA & UTA & UTA \\
LASA & NI & 50 & $>50$ & UTA \\
LASA & MEOH & 5 & $>5$ & UTA \\
LASA & Cd & UTA & UTA & UTA \\
LASA & ATRA & 50 & $>50$ & UTA \\
LASA & ANTH & 50 & $>50$ & UTA \\
\hline CEOC & PCE & 50 & $>50$ & UTA \\
CEOC & NI & 25 & 50 & UTA \\
CEOC & MEOH & 5 & 25 & UTA \\
CEOC & Cd & 25 & 50 & UTA \\
CEOC & ATRA & 25 & 50 & ECO5 $=17.97$ \\
CEOC & ANTH & 25 & 50 & UTA \\
\hline RASA & PCE & 50 & $>50$ & UTA \\
RASA & NI & 50 & $>50$ & UTA \\
RASA & MEOH & 5 & $>5$ & EC10 $=2.38$ \\
RASA & Cd & 50 & $>50$ & UTA \\
RASA & ATRA & 50 & $>50$ & UTA \\
RASA & ANTH & 50 & $>50$ & ECHO=28.16 \\
\hline QUFA & PCE & 50 & $>50$ & UTA \\
QUFA & NI & 50 & $>50$ & UTA \\
QUFA & MEOH & 25 & $>25$ & UTA \\
QUFA & Cd & 50 & $>50$ & UTA \\
QUFA & ATRA & 50 & $>50$ & UTA \\
QUFA & ANTH & 50 & $>50$ & UTA \\
\hline PAMI & PCE & 50 & $>50$ & UTA \\
PAMI & NI & 50 & $>50$ & EC10 $=49.56$ \\
PAMI & MEOH & 2.5 & 5 & EC10 $=2.61$ \\
PAMI & Cd & 25 & 50 & EC10 $=29.6$ \\
PAMI & ATRA & 50 & $>50$ & EC10 $=34.84$ \\
PAMI & ANTH & 25 & 50 & EC10 $=9.94$ \\
\hline SACE & PCE & 50 & $>50$ & UTA \\
SACE & NI & 50 & $>50$ & UTA \\
SACE & MEOH & 25 & $>25$ & UTA \\
SACE & Cd & 50 & $>50$ & UTA \\
SACE & ATRA & 50 & $>50$ & UTA \\
SACE & ANTH & 50 & $>50$ & UTA \\
\hline & & & &
\end{tabular}




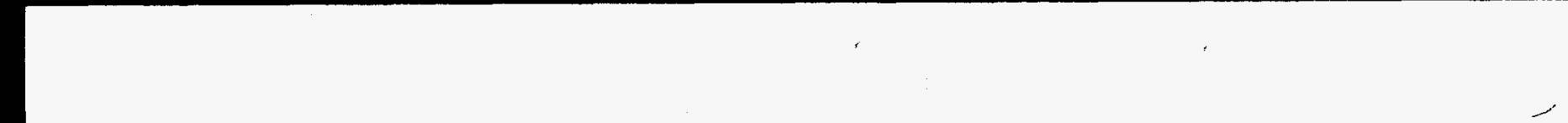




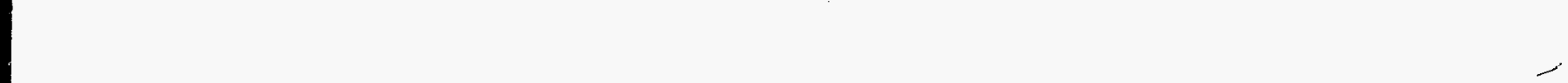




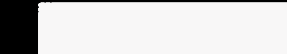

